
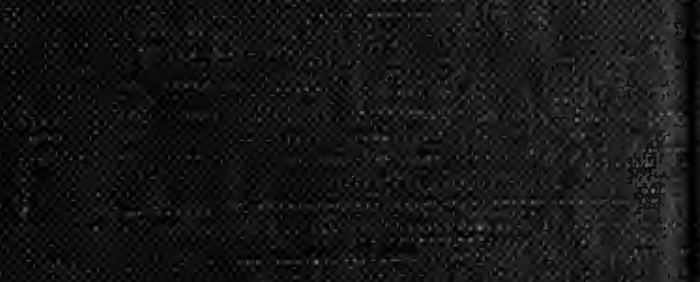

Dr. fl. Parsons 
Digitized by the Internet Archive in 2007 with funding from Microsoft Corporation 
CEREBROSPINAL FLUID IN HEALTH AND IN DISEASE 
. 


\title{
CEREBROSPINAL FLUID
}

\section{IN HEALTH AND IN DISEASE}

\author{
ABRAHAM IEVINSON, B.S., M.D.
}

ASSOCIATE, IN PEDIATRICS, NORTIIWESTERN UNIVERSITY MEDICAL SCILOL; ASSO-

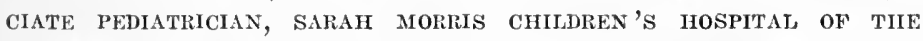

michael reese hospital, chicago; atTending pediatri-

Cian, mount sina hospital, Chicago; attending

PHYSICIAN, CHIDREN'S DEPARTMENT, CIII-

CAGO-WINFIELD TUBERCULOSIS

SANITARIUM

WITH A FOREWORD BY

LUDVIG HEKTOEN, M.D.

WITI FIFTY-SIX ILLUSTRATIONS, INCLUDING

FIVE.COLOR PLATES

ST. LOUIS

C. V. MOSBY COMPANY

1919 


$$
\begin{gathered}
\text { Wh } 203 \\
2657 \mathrm{C} \\
1919
\end{gathered}
$$

Copyright, 1919, By C. V. Mosby Company 
To Hin to Whom the Practice of Medcine Constitutes an Ideal Rather Than a Profession,

To Hin Who Combines Clinical Insight and Scientific Research,

To Him Who Sees in Medicine Both A Science ANd a Plillosophy,

This Literta Volune is Respectrulat Dedicated. 


\section{FOREWORD}

By Ludvig Hektoen, M.D.

The author was kind enough to ask me if I would look over his manuscript and then tell him whether it seemed to me worthy of publication. Later, when I told him that in my opinion he had produced a valuable little book, he requested me to state the reasons for this favorable opinion in the form of a foreword. This $\mathrm{I}$ ean do in a few brief statements.

In the first place, on reading the mamuscript, I soon became aware that the anthor had come to his task with not only a large experience behind him in the examination by various methods of the cerebrospinal fluid as an aid in diagnosis, but with a highly ereditable record in the scientific study of this fluid as well. Evidently he had been drawn to his work on the cerebrospinal fluid because of its attractiveness as a field of research, as well as on account of its importance in diagnosis.

It is to this happy combination of true philosophic interest and first-hand practical knowledge on the part of the author that the book owes its chief merit, namely, thoroughness and freshness in the parts dealing with fundamental problems, as well as in those dealing with practical matters. In the second place there could be no doubt in regard to the timeliness of a work of this kind. Indeed it seemed to me that a definite want would be supplied; for, in spite of an increasing importance in medicine, there was as yet no comprehensive book on all phases of the cerebrospinal fluid.

John McCormick Institute

For Infectious Diseases, Chicago. 


\section{PREFACE}

Of recent years the study of body fluids has been engaging the attention of many physicians and scientists. Particularly marked has been the interest in the study of cerebrospinal fluid. Through recent investigations of this fluid, we have gained a great deal of information regarding the diagnosis and nature of many diseases and a mmch clearer conception of the general physiologic processes in the body. Further investigations on the subject will open up new possibilities in science and medicine, for there is hardly another body fluid that presents so favorable an opportunity for the study of physiologic and pathologic processes in the human body as the cerebrospinal fluid.

Cerebrospinal fluid is of great physiologic importance for various reasons. It is the clearest and most transparent of all the fluids of the body. It is clearer than blood, than bile, and even clearer than urine, and under normal conditions experiments may be made on it without fear of clot formation or color change. Furthermore, cerebrospinal fluid, like blood and urine, can be removed from the living body without injury to the system. This gives one the opportunity of working with processes in the living body - a distinct advantage over the study of dead tissue.

From the standpoint of pathology also, cerebrospinal fluid presents an exceptional opportunity for study. The slightest change in the color of the fluid, the smallest increase in the protein content or in the cell count, all of which are easily discernible, indicate the presence of a pathologic process. One is able to follow the course of disease throughout all stages by noting the various changes 
the cerebrospinal fluid undergoes from time to time. These changes may be manifested not only by the presence of the causative organisms themselves, but just as frequently by specific physical, chemical, ertologic and physicochemical processes. A close study of the changes in the cerebrospinal fluid under pathologic conditions throws light, not only on the specific diseases of the nervous system, but on the condition of other systems. One can readily see, therefore, how large is the scope for the study of cerebrospinal fluid.

In this book I shall discuss cerebrospinal fluid in its various phases, and shall attempt to show the nature of the fluid in its normal state and to point out the deriations in processes of disease. I shall incorporate the results of my own clinical and experimental studies as well as the observations of the many workers who have added to our knowledge by their researches on cerebrospinal fluid.

This little book is sent out as an humble contribution, as I am fully aware of its many shortcomings and omissions; but if it saves the busy practitioner the irksome task of consulting countless sources for information on cerebrospinal fluid, I shall feel that the work has not been in vain. And if perchance it should serve to stimulate even one zealous student to help solve some of the problems presented, I shall feel that my effort has been amply rewarded.

Many of the investigations that have found their way into this volume would not have been possible without the constant cooperation of certain institutions and individuals. I, therefore, take this opportunity of expressing my gratitude to them collectively and individually - to the attending staff, internes and nurses of the Michael Reese Hospital in general, and the Sarah Morris Hospital for Children in particular, to Dr. Katharine Howell, serologist of the Nelson Morris Institute for Medical Research, to Professor F. C. Becht of the Department of Pharmacology of the Northwestern University, and to Dr. 
G. Bartelmez of the Departnent of Anatomy, University of Chicago.

Particular thanks are due to Prolessor Ludvig Hektoen of the University of Chicago for his helpful suggestions and for his careful reading of the manuscript, and to Professor Shiro Tashiro of the Department of Biochemistry of the University of Cincinnati for his tireless assistance in checking up many of the experiments. Thanks are also due the editors and publishers of the many journals for their permission to republish some of my articles that appeared in their jonruals.

Chicago, Ill.

A. Levinson. 



\title{
CONTENTS
}

\author{
CHAPTER I
}

PAGE

History of Cerebrospinat Fudud

\section{CHAP'TER II}

Axitomy and Pitysiology of Cerebrospinal Fluid

Loeation, 30; Formation and Absorption, 34; Permeability, 38; Function, 40; Origin, 41 .

\section{CIIAPTER III}

Metilods of Obtainiag Cerebrospinat, Fidid from the Living Body

Lumbar Puncture, 49; Untoward Eflects of Lumbar Puncture, 53; Technic of Lumbar Puncture, 54; The Spinal Puneture Needle, 57; Reasons for Failure to Obtain Fluid, 63; Pressure, 64; Collection of the Flnid, 69; Cranial Puncture, 71.

\section{CHAPTER IV}

Properties of Nordal Cerebrospinal Fluid

Physieal Properties, 76; Amount, 76; Color; 76; Lack of Sediment, 76; Pressure, 77; Specific Gravity, 79; Chemieal Composition, 79; Physicochemical Properties, 94; Specific Gravity, 94; Viscosity, 95; Conductivity, 95; Surface Tension, 95; Freezing Point, 95; Refractometric Index, 96; Reaction of Normal Cerehrospinal Fluid, 96; Alkaline Reserve, 105; Bioehemieal Properties, 107; Amylolytic Power, 107; Proteolytic Power, 107; Glycolytic Ferment, 107; Filsuin Ferment, 107; Alexin, 107; Hemolysin, 108; Toxicity, 108; Bacterieidal Action, 108; Cytology, 108; Type of Cell, 110.

\section{CHAPTER V}

Pathologic Cerebiospinal Fluid . . .

Increase in Amount of Fluid, 116; Pressure, 116; Foam, 117; Cells, 117; Pelliele, 118; Crystallization, 120; Permanganate or Organic Index, 123; Protein, 125; Preeipitation, 125; Sngar, 129; Turbidity, 131; Physical Chemistry, 132; Protein Charges, 133; The Colloidal Gold Reaction, 137; Mastic Reaction, 137; Ninhydrin Reaction, 1.:7; Changes in the Reaction of the Cerebrospinal Fluid, 138; Bacteriologie, 146; Immunologie, 147; $\Lambda$ gglutination, 147; Memolysin, 147; Wassermann Reaction, 148. 


\section{CHAPTER VI}

methods of Examination of Cerebrospinal Fluid for Diagnostic Purposes

Physical, 150; Color, 150; Foam, 151; Pellicle, 151; Chemical, 152; Increase of Protein, 152; Globulin Tests, 153; Noguchi, 154; RossJones, 154; Nonne-Apelt, 154; Kaplan Method, 155; Pandy, 155; Sulphosalicylic Mercuric Chloride Method, 155; Relatice Value of the Globulin Tests, 156; The Permanganate Test, 157; Sugar, 158; Chlorides, 161; Physicochemical Methods, 162; Lange Gold Chloride Test, 164; Mastic Test, 166; Cytologic Examination, 167; The Freneh Method of Cell Comnting, 167; Chamber Method of Cell Counting, 168; Comparative Value of the Two Methods, 169; Type of Cells, 170; Baeteriologie, 171; Culture Media, 171; Direct Smear, 172; Immunologic, 172; Macroseopic Method, 172; Mieroseopic Method, 175; Precipitation of Cerebrospinal Fluid with Antimeningococens Serum, 176; Guinea 1'ig Inoculation, 177; Nentralization Test, 177; The Wassermann Reaction, 177.

\section{CHAPTER VII}

Cerfbrospinal Fluid in Tarious Diseases

Uremia, 183; Diabetes Mellitus, 183; Chorea, 183; Epilepsy, 184; Mongolian Idiocy, 184; Psychoses, 185; Lnes, 185; Hydrocephalus, 188; Spina Bifida, 188; Hemorrhage of the Brain, 188; Tumors of the Brain, 189; Compression of the Cord, 189; Encephalitis, 189; Meningism, 190; Tuberculous Meningitis, 190; Meningococeus Meningitis, 194; Pneumococeus Meningitis, 200; Streptococeus Meningitis, 202; Influenza Meningitis, 203; Colon Meningitis, 203; Syphilitic Meningitis, 203; Cerebrospinal Fluid in Poliomyelitis, 205.

\section{CHAPTER VIII}

INTRASPINAL TREATMENT

Intraspinal Treatment of Meningococens Meningitis, 209; Untoward Effects of Serum, 216; Aggravation of Symptoms, 217; Serum Rash, 217; Intraspinal Treatment of Pneumocoeeus Meningitis, 217; Intraspinal Treatment in Tuberculous Meningitis, 219; Influenza Meningitis, 219; Polionyelitis, 219; The Swift-Ellis Treatment, 220; Intraspinal Treatment of Tetanus, 221; Intraspinal Treatment of Chorea, 222 .

CHAPTER IX

SUMMARY 


\section{ILLUSTRATIONS}

FIG.

PAGE

1. Albertus de Haller . . . . . . . . . . . . . . . 20

2. Franeois Magendie . . . . . . . . . . . . . . . . . 22

3. Lumbar region of skeleton of a one-year-old cliild . . . . . . 26

4. Lumbar region of skeleton of a six-year-old ehild . . . . . . 27

5. Section of human brain (Color Plate) . . . . . . . . . . 30

6. Diagram of Fig. 5 . . . . . . . . . . . . . . . 32

7. Chorioid plexus detached from the ventrieles . . . . . . . 33

8. Specimen illustrating the importanee of spinal puncture for diagnostic purposes . . . . . . . . . . . . . . . . 50

9. Opposite view of Fig. 8 . . . . . . . . . . . . 51

10. Section of cauda equina of a $\operatorname{dog}$. . . . . . . . . . 5 5

11. Plexus of vems, the punctmre of which is responsible for blood obtained during spinal puncture . . . . . . . . . 56

12. Various types of lumbar puneture needles . . . . . . . . . 58

13. Modified Quineke apparatus for measuring the eerebrospinal fluid pressure . . . . . . . . . . . . . . 65

14. Author's spinal puneture needle and manometer . . . . . . 67

15. Photograph showing ventricular puneture in an infant (front view) 72

16. Photograpl showing ventricular puneture in infant (side view) 73

17. Crystallization of nommeningitic cerebrospinal fluid . • . . . 59

18. Crystals of evaporated nonmeningitic ecrebrospinal 1luid . • . . 90

19. Crystals of sodium ehloride in a 1 per cent solution of dextrose 90

20. Average change in the $\mathrm{H}$-ion coneentration of nonmeningitic fluid on standing . . . . . . . . . . . . . . . . . . 99

21. Change in H-ion coneentration of nonmeningitic fluids on standing at room temperature under various conditions . . . . . 103

22. Photomierograph of stained pelliele from cerebrospinal fluid of a pneumococeus meningitis . . . . . . . . . . . . 119

23. Pellicle formation in miningitis . . . . . . . . . . . 120

24. Crystals formed in test tulse on spontaneous evaporation of eerebrospinal fluid from a case of tuberculous meningitis . . . . 121

25. Spontaneously evaporated cerelorospinal fhuid from a case of tuberenlons meningitis . . . . . . . . . . . . . . . . . 121

26. Spontaneonsly evaporated cerebrospinal fluid from a ease of pmenmococens meningitis

27. Crystals from an evaporaterl fluid in a ease of tuberculous meningitis

28. Crystals from an eviprorated fluid of a case of puenmococeus meningitis . . . . . . . . . . . . . . . . . .

29. Photograple showing the typieal ratio of precipitates by the two preeipitants 
30. Apparatus for cataphoresis of proteins

31. Change in the $\mathrm{H}$-ion concentration of three types of cerebrospinal fluid

32. Different effeets of eorking on tuberculous and epidemic fluids

33. Fuchs-Rosenthal chamber for eounting cells in cerebrospinal fluid

24. Nenbauer blood counting chamber whieh may be used for cerebrospinal fluid

3.5. Photograph showing agglutination of meningococei by the macroscopic method

36. Mieroseopie method of agglutinating meningoeocei

37. Agglutination of meningococei by the mieroseopie method . . . 175

38. Lange colloidal gold test in case of cerebrospinal lues . . . . 187

39. Lange colloidal gold test in ease of tabes . . . . . . . . 187

40. Lange colloidal gold test in ease of general paresis . . . . . 187

41. Lange gold chloride reaction in a case of tabes dorsalis (Color Plate)

42. Lange gold chloride reaction in a case of general paresis (Color Plate)

43. Lange colloidal gold test in a case of tuberculous meningitis

44. Lange gold chloride reaction in a ease of tubereulous meningitis (Color Plate)

45. Lange gold chloride reaetion in a case of meningococens meningitis (Color Plate)

46. Lange eolloirlal gold test in a case of meningoeoceus meningitis

47. Photomicrograph showing direct smear from cerebrospinal fluid

3 of case of meningococeus meningitis . . . . . . . . .

48. Twenty-four-hour eulture of meningocoeei grown in aseitie dextrose agar . . . . . . . . . . . . . . . . . 197

49. Photomicrograpl of pure meningoeoecus eulture . . . . . . 198

50. Photomicrograpl of smear from cerebrospinal fluid of pueumocoeeus meningitis . . . . . . . . . . . . . .

51. Photomicrograpls showing direet smear from eerebrospinal fluid of case of mixed streptococeus and pneumococens meningitis

52. Photomierograph showing direct smear from cerebrospinal fluid of case of influenza meningitis . . . . . . . . . . . . . 204

53. Photcmicrograph of pure culture of influenza bacilli . . . . . . 204

54. Lange eolloidal gold test in case of epidemic poliomyelitis . . 205

5.5. Instrument for the introduction of antimeningoeoceus serum by the gravity method . . . . . . . . . . . . . .

56. Temperature and pulse chart of a case treated by antimeningocoecus serum 


\section{CEREBROSPINAL FLUID}

\section{CHAPTER I}

\section{HISTORY OF CEREBROSPINAL FLUID}

The existence of water on the brain in pathologic cases was known to the ancients. Hippocrates is credited with tapping the rentricles in hydrocephalus. We have nothing to show, however, that the ancients knew of the existence of fluid in normal persons. There is no mention of cerebrospinal fluid in the early writings of Hippocrates. In the later Hippocratedian collection the brain is spoken of as a gland. The glandular nature of the brain in this instance, however, does not refer to the cerebrospinal fluid, but to the so-called secretion which the ancients believed was poured down from the brain into the pharynx. Herophilus in his writings shows that he knew of the existence of the ventricles and of the chorioid plexus, but not of the function of the chorioid plexus or of the contents of the ventricles. It seems but natural to suppose that Herophilus who dissected hundreds of human bodies should have known of the existence of cerebrospinal fluid in the ventricles. We wonder if it could be possible for so keen an observer as he not to notice the presence of a large amount of fluid in the cavity of the brain on cutting it open. Yet, in giving a description of the ventricles which he speaks of as the seat of the soul, he makes not the slightest reference to the presence of any fluid in the brain. There is a possibility, of course, that the lost books of Herophilus may have contained some reference to cerebrospinal fluid.

One finds the same. silence on the subject in other ancient 
authorities. Erasistratus of Julis (330-250) describes four cavities in the brain, but he makes no mention of fluid in them. Galen, who was thoroughly familiar with the construction of the ventricles, speaks of an "excrementitial liquid, expressed from several places in the brain into the ventricles, especially the fourth, where this liquid is stored and then purged into the nose through the ethmoid bones and infundibulum." The fluid referred to, howerer, may not be the cerebrospinal fluid. Hemesius of Emersa (born 340 A.D.) gives a minute analysis of the ventricles and the localization of mental power within them, but he does not speak of the fluid they contain. One would naturally turn to Vesalius for a deseription of cerebrospinal fluid, for it is a well-known fact that Vesalius knew the chorioid plexus and, therefore, must also have observed the fluid. Yet, though he devotes page upon page to a discussion of the localization of the soul, he merely mentions a watery humor of the brain, but gives no description of any humor that would indicate that he had the cerebrospinal fluid in mind. Mention of the presence of a fluid in the brain is found in the writings of Varolius (1543-1575). This scientist, who described the pons that bears his name, denied the existence of pneuma in the ventricles, and insisted that it was fluid and not pneuma that filled up the cavity of the ventricles. However, he gives no description of the fluid he recognized. The real discovery of cerebrospinal fluid is attributed to Contugno. Dominico Contugno is responsible for many discoveries in medicine. He discovered intestinal lesions postmortem in a case of typhoid; demonstrated the presence of albumin in urine on boiling; and discovered the aqueduct in the internal ear known subsequently as the aqueductus Contugni. In 1784 he made the important discovery of the presence of cerebrospinal fluid in living fishes and turtles, although he could not detect its presence in man. Though Contugno usually gets the credit for the discovery of the cerebrospinal fluid, 
Bilanchoni claims that Valsalva prior to Contugno found "an ounce of a certain liquid in cutting the cord membrane of a $\operatorname{dog}$, a fluid resembling that seen in articulations."

The absence of a method whereby normal cerebrospinal fluid could be demonstrated in living beings was responsible for the lack of interest shown in the investigations of this fluid. Whatever interest there was, was confined to pathologic cases. In 1727 Stalpartius Vander Wiel described a case of injury to the head in which a clear watery fluid was seen to escape from the ear for several days after the injury. In 1764 Robert Whytt appeared with a description of tuberculous meningitis. He divided the disease into three stages according to the behavior of the pulse, and attributed the various manifestations of the disease to the presence of a serous exudate. In 1768 he published the results of his work on acute hydrocephalus under the title "Observations on Dropsy of the Brain." Under the heading of acute hydrocephalus he included all forms of acute brain disease.

For a clear-cut description of cerebrospinal fluid in normal persons we must turn to the writings of Albertus de Haller (Fig. 1). In the "First Lines of Physiology" in the third Latin translation, we find the following description:

"The fluids, which, being deposited from the blood into other vessels, are said to be secreted, seem reducible to four classes. The first consists of viscid fluids, coagulable by a heat of about $150^{\circ}$, by alcohol, and by strong acids, although generally, in the living animal, they escape in the form of vapor and after death are compacted into a gelatinous substance. To this class belong the liquor and halitus of the ventricles of the brain, the pericardium, pleura, peritoneum, tunica vaginalis, amnois, joints, renal capsules, and probably of the womb, with the juices of the stomach and intestines, and lastly the lymph generally known."

A little further Haller goes on as follows: 
"Have lymphatic vessels been seen with certainty in the brain? They have been described in the large chorioidal plexus amongst the fibers of the olfactory nerve, and in the pia mater. For my own part, I have never seen them, and it is probable that there are none, since there are no conglomerate glands in the brain, which are always found near these vessels. As for the various accounts which are given of the pituitary glands, to the infundibulum and of the ducts which lead from thence into the veins of the head, absorbing water from the ventricles, they are not sup-

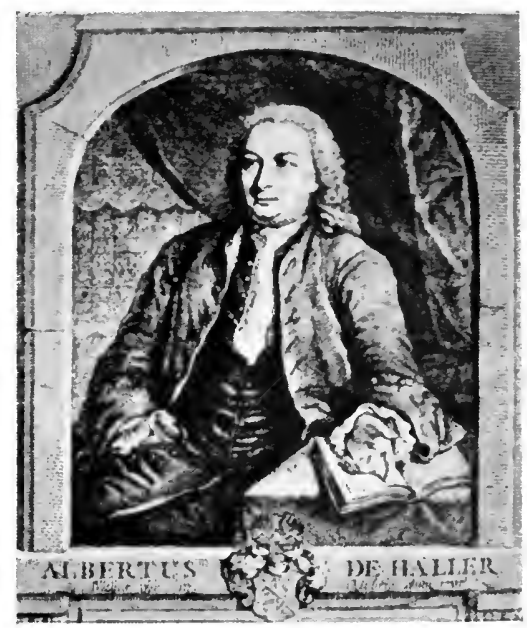

Fig. 1.-Albertus de Ifaller (1708-1777).

ported by any anatomic demonstration; which makes it probable that the vapor, which is secreted into the ventricles of a healthy person, is, in like proportion, absorbed again by the inhaling veins; and that if there be any excess, it descends through the bottom of the ventricles to the basis of the skull, and into the loose cavity of the spinal marrow. That this is the case, appears from the palsies, which ensue after apoplexies and from the watery tumors in the lower part of the spinal marrow, in hydrocephalic patients." 
Haller thought that the fluid not only was secreted in the lollow tubes of the medulla, but that it also flowed into the small tubes of the nerves. In the quotation that follows may be found part of Haller's explanation of the mechanism of irritability, the original conception of which was advanced by Glisson.

"Upon the whole, it seems to be certain that, from the vessels of the cortex, a liquor is secreted into the hollow tubes of the medulla, which, being continued into the small tubes of the nerves, and propelled to their extremities, is the cause of both sense and motion. But there will be a twofold motion in that humor; the one slow and constant from the heart; the other, not continual, but exceedingly swift, which is excited either by sense or any cause, as motions arising in the brain."

It is evident from Haller's own statement that he knew of the existence of cerebrospinal fluid in the ventricles and of the course of its circulation. However, with all his knowledge he does not seem to have been aware of the real nature and composition of the fluid. It was left to Magendie (Fig. 2) (1825) to give us an accurate description of the workings of the fluid, especially the fluid at the base of the brain. We are indebted to him for a clear-cut conception of the physical appearance and protective function of the cerebrospinal fluid. The following is taken from Magendie's treatise on Physiology:

"But there is a disposition unknown to Bichat, which I have recently discovered, and which contributes in a manner extremely efficacious to the conservation and defense of the medulla.

"The canal which is formed around the medulla by the pia mater, and which is lined by the arachnoid, is a great deal larger than is necessary to contain the organ; but during life the whole interval is filled up by a serous liquid, which strongly distends the membrane and which spouts out to many inches in height from a small puncture made 
in the dura mater. An analogous arrangement is also to be observed around the brain and cerebellum. It is easy to conceive how efficacious must be the protection thus derived from the liquid which surrounds the spinal marrow, and in the midst of which it is suspended like the fetus in utero; with this difference that it is fixed in its position by the ligamentum dentatum, and the different spinal nerves.

"Besides the different envelopes of the brain of which we have spoken, and the dura mater which covers it in its

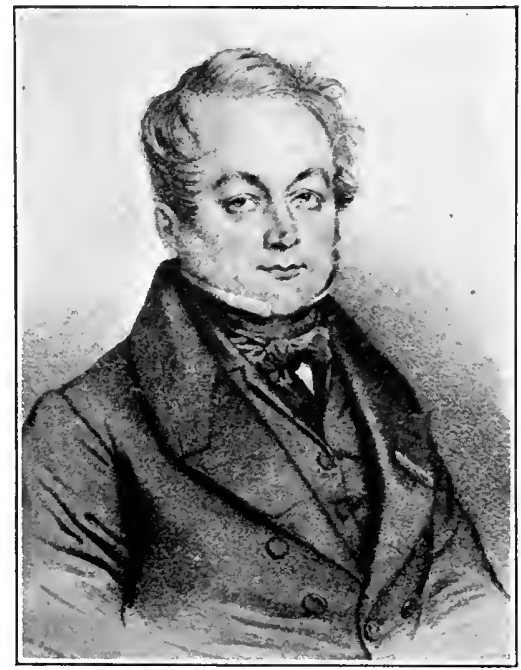

Fig. 2.-Francois Magendie (1783-1855).

whole extent, this substance is everywhere surrounded with a very fine serous membrane the principle use of which is to yield a thin fluid, which lubricates the brain. The arachnoid penetrates to all the cavities of the brain."

It is evident, therefore, that Magendie knew not only of the existence and appearance of the cerebrospinal fluid, but that he was also aware of the most significant function of the fluid-namely, its protective nature. As soon as Magendie opened the way for the study of cerebrospinal 
fluid, a number of other investigators followed in his path. Luschka and Eckar studied the fluid from an anatomic standpoint. Cavazzani performed numerous experiments on dogs to determine the physiologic character of the cerebrospinal fluid. Namyn made a study of the physics of cerebrospinal pressure. Shortly after, in 1842, Lange's Anatomy appeared and in it were nime pages devoted exclusively to the discussion of cerebrospinal fluid,- - a discussion that was both lucid and graphic.

Almost simultaneously speculation began as to thie source of cerebrospinal fluid. Carl Schmidt, in 1850, expressed the view that the cerebrospinal fluid was not a mere transudate from the blood. Faivre, in 1853, advanced the theory that the fluid was a secretion. Numerous investigations followed the promulgation of this idea, and hundreds of experiments were undertaken by anatomists, pathologists, physiologists, and chemists, experiments that are being carried on to this very day.

With the discovery of a method whereby cerebrospinal fluid could be removed from the living body, a new era was usliered into the history of this fluid. One of the first means of obtaining the cerebrospinal fluid was by removing it from the skull. This operation was fraught with many difficulties. It involved the use of a great number of instruments and necessitated trephining of the skull and the making of a scalp wound.

A great improvement was made on this method in 1855 . Corning injected 20 minims of a 2 per cent solution of hypochlorate of cocaine into a space situated between the spinous processes of two of the inferior dorsal vertebræ of a dog. Five minutes after the injection there were marked evidences of incoordination in the posterior extremities. A few minutes later there was pronounced weakness in the hind legs, but there were no signs of feebleness in the anterior extremities. The faradic current 
showed that there was no reflex action of the hind legs, but the anterior extremities responded quickly.

Corning then injected 30 minims of a 3 per cent solution of cocaine hypochlorate between the spinous processes of the eleventh and twelfth dorsal vertebra, in a man suffering from spinal weakness. As there was no numbness noticeable, he injected 30 minims more in the same spot about six or eight minutes later. In ten minutes the man complained that his legs felt "sleepy," and brush applications showed that sensibility was greatly impaired.

As a result of his experiments Corning came to the conclusion that local medication by means of spinal puncture could prove of great therapentic value in relieving a number of morlid conditions of the cord. Unfortunately, however, Corning left us neither a description of the technic he employed nor of the type of needle he used. Moreover, his operation was attended with a great degree of risk in that he introduced the needle too high up in the spinal columm, thus incurring the danger of injury to the cord.

In $1891 \mathrm{~W}$. Essex Wynter reported the drainage of cerebrospinal fluid in four cases of tuberculous meningitis. He treated his first case in 1889, making an incision in the skin of a patient suffering from tubereulous meningitis. Tn the incision which was made a little to one side of the spine of the second lumbar vertebra, he introduced a Southey tube and a trocar. Then he felt that the point of the trocar had struck against the lamina, he directed it slightly downward, forced it through the ligamentum and theca, and then inclined it toward the median line. When the trocar was: withdrawn, clear fluid rushed out into the Southey tube. A fine, India-rubber tube was then connected to facilitate continnous drainage. The symptoms of the disease subsided immediately, although the patient subsequently died from tuberculons meningitis. From 1889 to 1891, Wynter treated three more cases of tuberculous meningitis, :- 
all of them showed inprovement for a while, although they subsequently suceumbed to the disease.

Charles A. Morton (1891) followed the method outlined by Wynter. In discussing the pathology of tubereulous meningitis with reference to its treatment by tapping the spinal subarachnoid space, Morton says:

"What symptoms can be relieved by it only the practice of the operation can show; that out of four cases operated on in the Middlesex Hospital in one there should have been contraction of the unduly dilated pupils, and in another slight improvement in the general condition, is encouraging when we remember that drainage was not maintained in all the cases. The operation does no harm and as the patient is already comatose, no anesthetic is required."'

Morton, we see, tapped the patient when he was already in comatose condition. Although he does not state definitely just what technic he employed, he does, at the beginning of his article speak of the recent procedure "of tapping the subarachnoid space of the spinal cord in cases of tuberculous meningitis.' This would seem to indicate that he followed the method of Wynter; namely incision of the skin, introduction of a trocar between the vertebra and the use of a continuous drain.

For the simplification and perfection of the spinal puncture we must turn to Quincke. Corning, who was the first to use spinal puncture, employed an operation that was franght with danger to the cord, as the point at which he introduced the needle was too high up in the spinal canal. Wynter, it is true, did his puncture in the lumbar region, but his method necessitated the use of a large trocar, a continuous drain and a large incision in the skin. The procedure of Quincke was a vast improvemeut over those of his predecessors, both from the standpoint of simplicity and of safety. Quincke used only a plain neerlle and he so perfected the technic of spinal puncture that there is little that an be improved in his original method. 
At the Tenth Congress for Internal Medicine, Quincke reported two cases of hydrocephalus treated by means of withdrawal of the cerebrospinal fluid. The first was one of chronic hydrocephalus in which the fluid was removed by trephining and in which the contractures of the extremities and of the neck subsequently disappeared. The second was that of a child in which lumbar puncture resulted in great improvement. From these and similar observa-

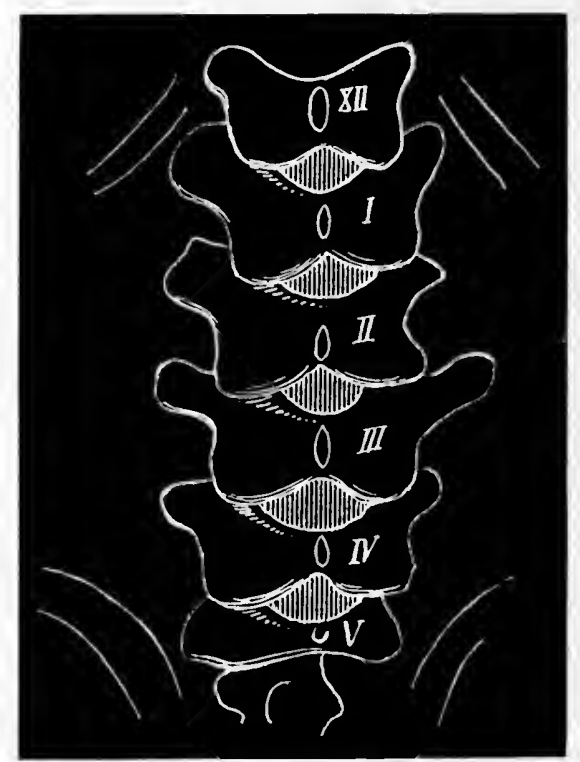

Fig. 3.-Drawing accompanying original article on lumbar puncture by Quincke, representing lumbar region of skeleton of a one-year-old child.

tions Quincke concluded that spinal puncture for therapeutic purposes was indicated in marked cerebral pressure, especially in cases of tuberculous meningitis and acute hydrocephalus. Quincke not only described the technic of spinal puncture, but he also measured the pressure of the cerebrospinal fluid and determined its chemical composition so far as he was able with the chemical technic at his command. (Figs. 3 and 4.) 
For two years after Quincke's experiments with spinal puncture no reports appeared in literature regarding its use. It was not until 1893 that Lichtheim called attention to spinal puncture as a valuable aid in diagnosis, and two years later, in 1895, Fübringer reported 107 punctures in eighty cases. In America, Browning, in 1894, reported a

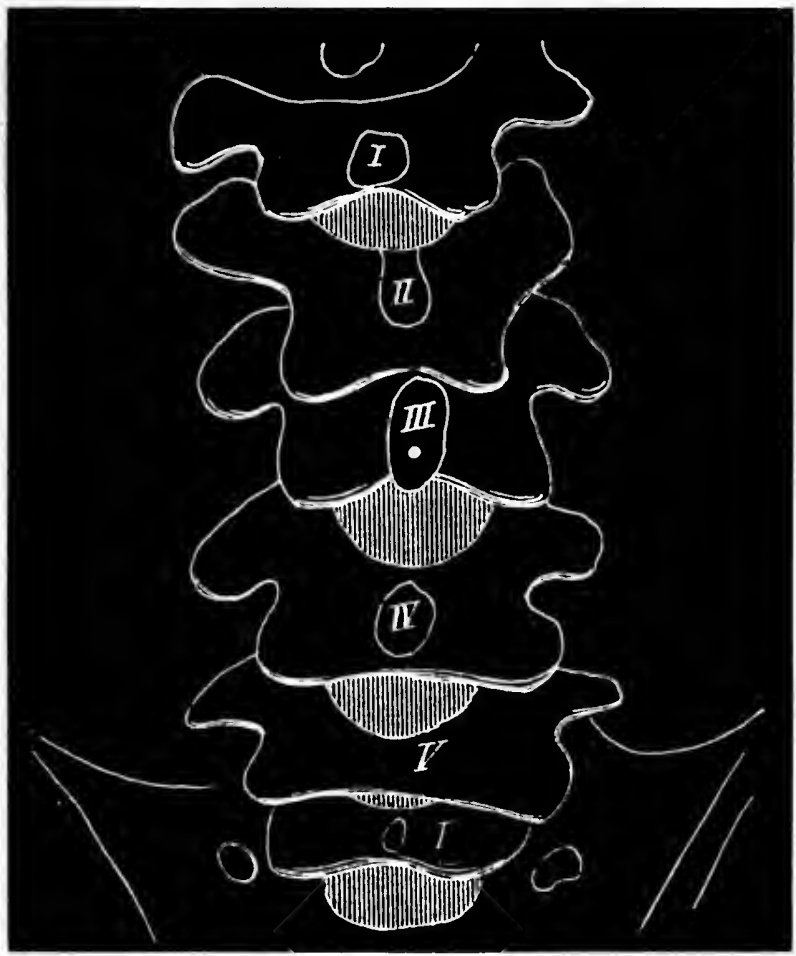

Fig. 4.-Drawing accompanying original article on lumbar puncture by Quincke, representing lumbar region of skeleton of a six-year-old child.

series of spinal punctures and G. WV. Jacoby, in 1895-6, reported 30 punctures. Since 1896 spinal puncture has been quite generally adopted as a routine procedure for diagnostic and therapentic purposes.

Bacteriology, serology, and chemistry have all played an important role in shaping the history of the cerebrospinal 
fluid. As for bacteriology, there is hardly a discovery that does not bear a more or less direct relation to the history of cerebrospinal fluid. The discovery of the tubercle bacillus by Robert Koch changed the name of acute hydrocephalus to tuber'ulons meningitis, and the conception as to its nature accordingly. The discovery in 1885 by Leichtenstern of intracellular diplococci, later elaborated with greater accuracy by Weichselbaum (1S87), changed the name of "spotted fever" and "epidemic cephalalgia" to meningococeus or epidemic meningitis, and the discovery of pneumococcus by Fränkel and of influenza bacillus by Pfeiffer did much to clear up the understanding of meningitis by introducing sustem where chaos previonsly reigned.

Serology has added a great deal to the diagnostic and therapentic uses of the cerebrospinal fluid. Bordet's discovery of complement fixation, Ehrlich's work on immunity and Wassermann's serologic test all found practical applications in the cerebrospinal fluid. However, probably the most heneficial contribution in the field of serology was the discovery of antimeningococcic serum by Jochmamn, in Germany and by Flexner in America and the introduction of the intraspinal injection of the serum by Flexner.

Chemistry, too, has had its share in shaping the history of the cerebrospinal fluid. It has shown us the composition of this, the clearest of hody fluids, and has shed light on the diagnosis of meningitis and other affections of the central nervous system.

Finally, the recent offspring of science, physical chemistry, is making its impress also on the history of cerebrospinal fluid. The H-ion concentration, cataphoresis, the Lange colloidal gold test, the ninhydrin reaction and the precipitation tests, all of which are hased on physicochemical principles, have thrown light on diseases of the central 
nervous system in general and on the composition of body fluids in particular.

We see that it would hardly be an exaggeration to say that the history of cerebrospinal fluid in many respects is but a miniature history of modern medicine.

\section{Bibliography}

Contugno: De Ischiade nervosa Commentarius, Dissertation de Sandifort, 1769 , ii, 411.

Jour. de physiol. exper., 1769, vii, s3.

Corning: Spinal Anaesthesia and Local Medication of the Cord, New York Med. Jour., 1885, xlii, 483.

Haller: Physiologie des Mensehen, 1766

Levinson: History of Cerebrospinal Fluid, Am. Jour. Syph., 1918, ii, 267.

Longet: Anatomie et Physiologie dne Systeme Nerveaux, 1842, i, 193.

Magendie: Memoire sur un liquide qui se trouve dans le erane et la eolome vertebrale de l'homme et des animanx mammiferes, Compt. reud. Aead. d. se., Jan. 10, 1825.

Magendie: Recherehes Physilogiques ef Cliniques sur le Liquide CephaloRarhidien: ou Corebrospinal, l'aris, $184:$.

Morton: The Pathology of Tubereulons Meningitis with Referenee to $i$ ' Treatment by Tapping the Subarachnoid Space of the Spinal Cord, Brit. Med. Jour., 18.11, ii, 840.

Quincke: Über Hydrocephalus, Verhandlungen der Cong. fïr Immere Med., $1891, \mathrm{x}, 321$.

Whytt: Observations on the Dropsy in the Brain, Works of Rohert Whytt, 1768.

Wynter: Four Cases of Tubereular Meningitis in Which Paracentesis of the Theea Vertebralis was lerformed for the Relief of Fluid Pressure, Laneet, London, 1891, i, 981. 


\section{CHAPTER II}

\section{ANATOMY AND PHYSIOLOGY OF CEREBRO- SPINAL FLUID}

\section{LOCATION}

The brain and spinal cord are surrounded throughout their length by a bed of fluid called the cerebrospinal fluid (Liquor cerebrospinalis, liquide cephalorachidien, Zerebrospinalflüssigkeit). Besides the fluid that surrounds the brain and cord there is also a small quantity of fluid in the ventricles of the brain.

The subarachnoid space is situated between the inner vascular layer of the meninges, the pia, and the outer thin layer of the meninges, the arachoid. It is subdivided into numerous compartments by means of delicate trabecula which run from the pia to the arachnoid. The subarachnoid space is not of the same depth everywhere. In some places it is quite wide and the trabecula are quite long, whereas in others, especially over high convolutions of the brain, the opposite is the case, the space being very small and the trabeculie very short. The various wide spaces are known by special terms suggestive of their form. Among the most important are the cisterna magna, which is located between the under surface of the cerebellum and the medulla; the cisterna pontis which is the continuation of the subarachnoid space of the spinal cord upwards to the floor of the cranium; and the cisterna basalis which is sitnated in front of the pons. The subarachnoid space of the cord, like that of the brain, is subdivided by trabeculæ, or septa, and is also quite wide.

In addition to the fluid contained in the subarachnoid space of the brain and cord there is fluid in the ven- 


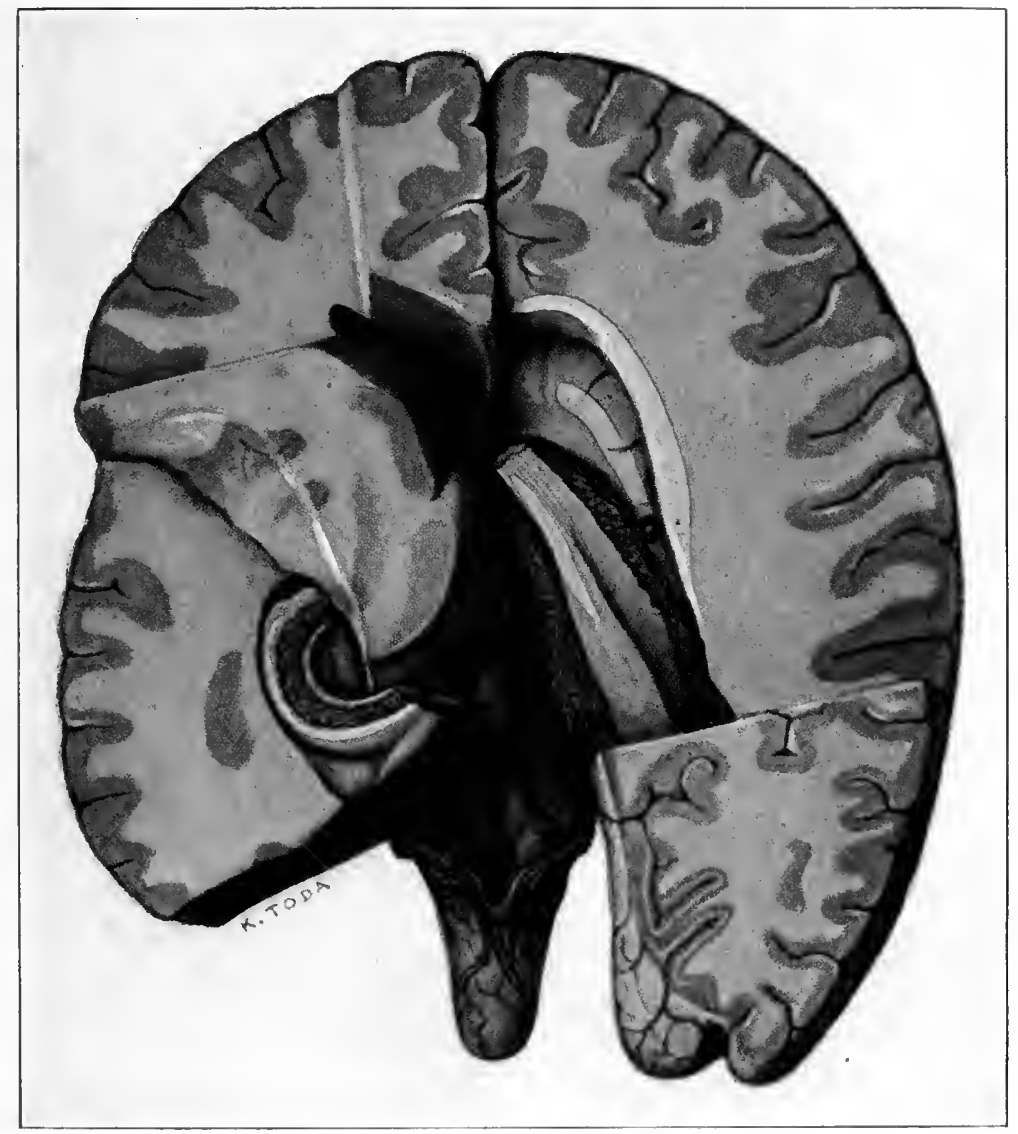

Fig. 5.- Section of human brain showing the chorioid plexus, the extent, relations, and intercommunications of the brain ventricles (see lig. 6.) 
tricles of the brain: the two lateral, the third, the fourtl, and the fifth ventricles (Figs. 5 and 6 ).

Lining the ventricles there is a tuft of blood vessels, covered by a single layer of epithelium called the chorioid plexus (Figs. 5, 6 and 7). This plexus is an ingrowth or folding of the pia, the layer of the meninges immediately adjacent to the brain.

Two-thirds of the blood supply of the plexus in man is furnished by the anterior chorioid branch of the internal carotid artery which enters the plexus at the anterior end of the descending cornu. The remainder is supplied by the posterolateral chorioid artery, a branch of the posterior cerebral. These arteries break up into arterioles, the largest of which are visible to the naked eye. After passing through the network of capillaries, the blood returns through the chorioid rein to the internal cerebral veins where it joins its fellow and forms the cerebral vein, or vein of Galen.

The walls of the blood vessels of the chorioid plexus, measure, in some tufts, $0.2 \mathrm{~mm}$. in thickness, while in others they form only a thin membrane between the lumen and cuboidal cells on the surface. Nuch variation exists also in the size of the lumina.

Sundwall divides the vessels of the chorioid plexus into two groups: (1) The vessels with thick walls, which as a rule, possess narrow lumina and have the same general structure as the small arteries. Weigert's stain shows a well-developed internal elastic layer, which in most instances is corrugated. In the media, which is quite well developed, fine, wary, elastic fibers may be seen. The fibers may be traced to the cuboidal cells for which they frequently form a basic membrane. (2) The second group of vessels are those with comparatively thin walls and wide humina. These may be regarded as veins or simuses. No muscular tissue can be made out in the walls of this second group, the walls being composed almost entirely of 


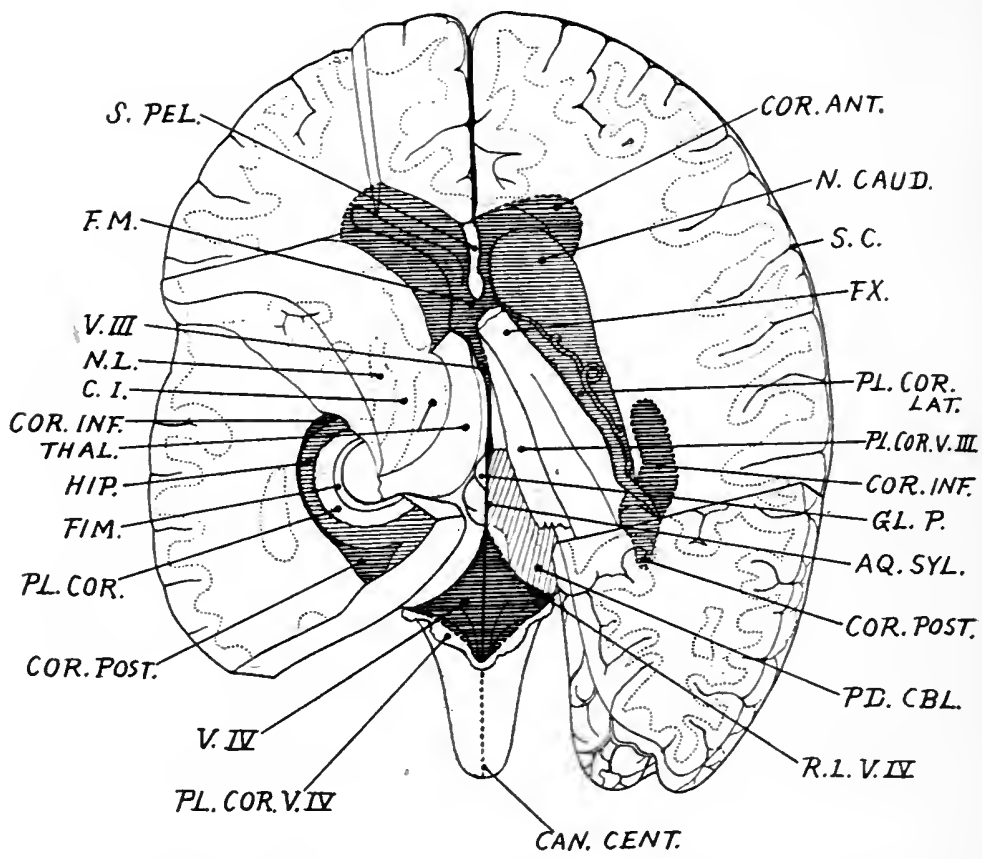

Fig. 6.-A diagram of Fig. 5. The ventricles are deeply shaded. The outlines of the ventricles which appear in Fig. 5 are indicated by continuous lines. On the right side the position of the underlying ventricular cavities is also indicated by shading, but the outline is a braken line.

S. PEL., Septum pellucidum.

F. M., Foramen of Monro.

$V$. III., Third ventricle.

N. L., Lentiform nucleus.

C. I., Internal capsule.

COR. INF. Inferior liorn of lateral ventricle.

THAL.. Optic thalamus.

HIP., Hippocampus.

FI.I., Fimbria.

$P L$. COR., Lateral chorioid plexus.

COR. POST., Posterior horn of lateral ventricie.

$V$. IV., Fourth ventricle.

$P L$. COR. $I$. $I V$., Reflected chorioid plexus of fourth ventricle.

CAN. CENT., Position of central canal.

COR. ANT., Position of anterior horn of lateral ventricle.

N. CAUD., Caudate nucleus.

$S$. C., Fissure of Rolando (central sulcus).

$F X$, Fornix cut through at column of the fornix.

PL. COR., LAT., I,ateral chorioid plexus.

$P L$. COR. $V$. III., Reflected chorioid plexus of third ventricle and septum inter. positum.

COR. INF., Position of the inferior horn of lateral veritricle.

$G L$. P.. Left half of pineal body.

$A Q . S Y L$. . Aqueduct of Sylvius.

COR. POST., Position of posterior horn of lateral ventricle.

$P D$. CBL., Cut surface of cerebellar peduncles.

$R$. L. $V$. IV., l,ateral recess of fourth ventricle. 
white fibrous commective tissue and are so sinilar throughout in their structure that they can not be differentiated into intima, media, and adventitia. Only here and there may be seen a few fine elastic fibers.

The walls contain numerous small ressels and capillaries (vasa vasorum) of varying caliber. They are rich also in muclear elements, such as endothelial cells, connectivetissue cells and interstitial gramule cells.

The cerebrospinal fluid in one ventricle of the brain communicates directly with the fluid in the other ventricles

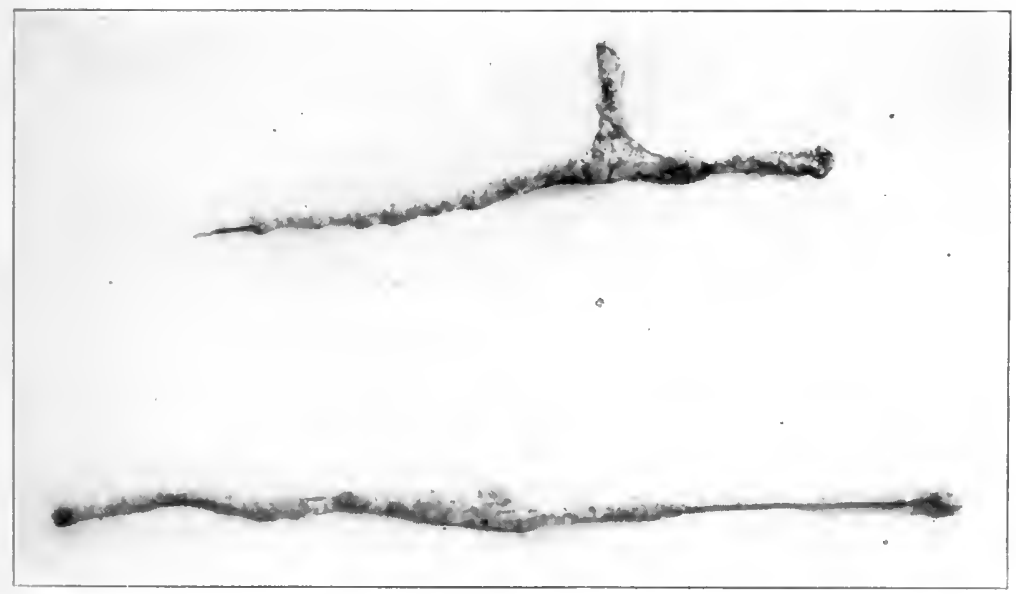

Fig. 7.-Photograph of a chorioid plexus detached from the ventricles.

through the various openings commecting them. The only exception to this rule is the fifth rentricle which contains very little or no fluid. T'hus, the fluid in the lateral ventricles flows into the third through the formmen of Monro, and the fluid in the third commminates with that in the fourth by means of the aqueduct of Sylvius. (Figs. 5 and 6.)

The cerebrospinal fhid of the subarachnoid space communicates with the fluicl in the ventricles of the brain through the foramen of Magendie which opens into the 
posterior part of the fourth rentricle and through the foramina of Luschka and numerous other apertures which open into the lateral ventricles. Some author's, notably Schmorl, claim that no communication exists between the cerebrospinal fluid in the ventricles of the brain and the fluid in the subarachnoid spaces of the brain and cord. They base this claim on two observations: (1) the finding of bile in cases of icterus in the cerebrospinal fluid of the cord, but not in the fluid of the ventricles; (2) by Schmorl's finding of a positive Nomne-Apelt reaction in the cerebrospinal fluid of the cord and a negative reaction in the fluid of the ventricles.

My own observations do not bear ont the conclusion of Schmorl. I examined both the spinal and ventricular fluid in cases of meningitis and found them quite alike in both their globulin and bacterial content. In fact, in my cases, the ventricular fluid at times gave much stronger globulin reactions than did the fluid from the spinal canal. However, the best evidence that a communication exists between the rentricles of the brain and the subarachnoid spaces is the commonly observed fact that in hemorrhages into the ventricles the fluid obtained by lumbar puncture contains coagulated blood. It is also well known that when a colored fluid is injected into the rentricles, it can be recorered by lumbar puncture in a few minntes. Vice rersa, if the colored fluid is injected between the atlas and axis it can be recovered from the lateral ventricle. It is also well known that a tense fontanelle will go down with the withdrawal of cerebrospinal fluid by lumbar puncture. All this points to a direct communication between the ventricles of the brain and the subarachnoid space.

\section{FORMATION AND ABSORPTION}

The rate of formation of cerebrospinal fluid is still a matter of conjecture. Falkenheim and Naunrn observed 
that from 1 c.c. in six minutes to 1 c.c. in forty minutes flowed out of a cannula introduced into the subarachnoid space of a dog. In another dog, weighing 23 kilos, they observed as large a flow as 240 c.c. of fluid in twenty-four hours and in still another dog, weighing 20 kilos, they reported a flow of 36 c.c. in twenty-four hours. According to these experiments there does not seem to be any relation between body weight and the rate of formation of cerebrospinal fluid nor between the rate of formation and the arterial pressure. In the numerous reports of cases of cerebrospinal rhinorrhea, the amount of fluid flowing out from the nose varied from 96 c.c. to 720 e.c. per day. Tillaux, for instance, reports a case in which there was communication between the subarachnoid space and the dura and in which the daily flow of cerebrospinal fluid from the nose averaged one-fourth of a liter. Wallace MacKenzie reports a case of cerebrospinal rhinorrhea where the average flow of fluid per hour was one ounce, making a total of 720 c.e. in a day. In trauma of the spinal column even greater amounts of fluid have been observed, as in the case of Giss in which there was a flow of fluid measuring from one and one-half to two liters. It seems likely, however, that the large amounts of cerebrospinal fluid observed in cases of trauma are no indication of the normal rate of formation in cerebrospinal fluid, as it is well known that whenever there is irritation of a serous membrane there is an increase of the fluid in the cavity.

So far as we know, no one has as yet determined the rate of formation of cerebrospinal fluid under normal conditions. One point, however, has been quite definitely established by Falkenheim and Naunyn and that is that there is a constant secretion and absorption of the fluid.

That the cerebrospinal fluid has a circulation has been shown by Magendie, but the mode of circulation has not been entirely established. It is thought that the fluid starts in the ventricles of the brain, that it passes through 
the foramina of Magendie and Luschka into the subarachnoid space of the brain, then downward along the posterior aspect of the spinal cord. On reaching the end of the cord the fluid passes upward along the anterior surface of the cord. Some of the fluid is absorbed there. The rest spreads over the convexities of the hemispheres from whence it is absorbed.

The data on the absorption of the cerebrospinal fluid are not numerous. Duret was able to introduce 583 c.c. of water into the subarachnoid of a dog in the course of two hours. Naunyn and Schreiber introduced 400 c.c. of physiologic salt solution into the subarachnoid space of a dog, weighing $91 / 2$ kilograms, in the course of an hour and three quarters, using $100 \mathrm{~mm}$. mercury pressure for the injection. Falkenheim and Namyn showed that the absorption is rapid even when the fluid is injected with a very little force. Dandy and Blackfan injected 1 c.c. of phenolsulphonephthalein into a dog after withdrawing 1 c.c. of cerebrospinal fluid. They examined the quantity of phenolsulphonephthalein excreted in the urine by a colorimetric method, and found that in the first hom after the injection there were 16.6 per cent of phenolsulphonephthalein excreted in the urine; in the second, 17.8 per cent; in the third, 13.6; in the fourth, 7.2 per cent; in the fifth, 4.5 per cent; in the sixth, 2.2 per cent; in the serenth, 1.3 per cent; and in the eighth, 1.3 per cent. From these experiments they concluded that the absorption of the cerebrospinal fluid is fairly regular for a period of from three to four hours, and that it diminishes progressively after this time. They set a minimum of four to six hours for the completion of absorption of the fluid, making four to six renewals in 24 hours.

The above, however, can not be taken as an index for the rate of absorption of the cerebrospinal fluid, as phenolphthalein is a foreign substance, and, as is well known, a foreign substance is rapidly eliminated from the body, 
without reference to the absorption power of the body fluids. One, for instance, is not justified in saying that since 60 per cent of a dye is excreted in the urine in two hour's by the kidney, 60 per cent of the water of the blood is excreted in two hours. Foreign substances are eliminated by a special mechanism and bear no relation to the absorption of the body fluids.

So far the rate of absorption of cerebrospinal fluid has not been determined, and we believe will not be determined so long as the rate of formation of the fluid is not known, for the rate of absorption natmally depends on the rate of formation.

As for the channel through which absorption of the cerebrospinal fluid takes place, there is a divergence of opinion. Mott considers the perivascular lymphatics as the channel of absorption. It has been proved by others, also, that a portion of the fluid is drained by the lymphaties into the deep cervical glands, and that a small portion flows into the lymph vessels of the nose, the perilymph spaces of the labyrinth of the ear and in the perineural sheets. This is somewhat substantiated by the cases of cerebrospinal rhinorrhea reported in the literature. It has been found, however, that normally the absorption by way of the lymphatic system removes only a very small quantity of the fluid. Hill, Ziegler, and Spina showed that methyl blue injected into the subarachnoid space can be recovered from the stomach in twenty minutes, while it takes hours before the lymphaties of the neck are discolored by the stain. Dandy and Blackfan introduced a cannula into the thoracic duct after they had injected phenolsulphonephthalein into the subarachnoid space and found that there was very little absorption by the lymph, compared with that by the blood.

These and many other experiments indicate that the greatest amount of cerebrospinal fluid is absorbed into the blood stream proper. According to Schwalbe, Key and 
Betzins, the Pacchionian bodies perform the function of absorbing the fluid, but according to recent studies these bodies are concerned only little in this absorption. Bohn, Reiner and Schnitzler advocate the idea that the fluid is absorbed by the stomata of the meninges. This theory, however, has no real foundation, and at present the weight of evidence is in favor of the absorption of the cerebrospinal fluid by a process of diffusion into the blood from the subarachnoid space of the brain, and particularly of the cord.

\section{PERMEABILITY}

It is conceded by most observer's that muder normal conditions no foreign substances, or at least very few, pass from the blood into the cerebrospinal fluid. This resistance of the meninges to the entrance of a foreign substance is held to be due to the impermeability of the meninges, although, if we accept the view that the cerebrospinal fluid is secreted by the chorioid plexus we should speak rather of the impermeability of the chorioid plexus. Various experiments have been made to demonstrate this property of the chorioid.

Cavazzani injected potassium iodide into dogs intraperitoneally and recovered only very small amounts of it in the cerebrospinal fluid. Sicard, Lewandowsky, and Rotky repeated the experiment and could not detect potassium iodide in the cerebrospinal fluid at all. Lewandowsky found that a few centigrams of sodium ferrocyanide injected into subarachnoid space rapidly produced toxic symptoms while four to six grams injected into the jugular vein in rabbits of the same weight produced no specific symptoms. This could not have been attributed to the solution employed, for a 10 per cent salt solution injected into the subarachnoid space produced only slight effects. Lewandowsky was also able to show the transmissibility of only very small traces of strychnine in the cerebrospinal 
fluid of animals, but none in man. Von Jaksch and Sicard could not detect the presence of mercuric salts after inmetion into the skin. Livon and Bernard could detect salicylates, but in very small amounts, in the cerebrospinal fluid of a dog after intravenous injection.

Antitoxin also passes over into the cerebrospinal fluid only in traces. Behring injected hens both subcutaneously and intravenously with tetanus toxin and found that they suffered no ill effects. However, when he injected the same amount of toxin into the subdural space the hens died from typical tetanus.

Mestrezat found that when sodium nitrate is administered to a normal individual before a spinal puncture is made, the fluid shows very little or no nitrate, while in cases of meningitis, the drug is present in large quantities.

There are a few chemical substances, however, that do seem to be transmitted from the blood into the cerebrospinal fluid, namely, hexamethylamine, alcohol and chloroform. Hexamethylamine has been slown by Crowe, Hold and Ratsky to be present in the cerebrospinal fluid of both man and animal after administration by mouth. This observation has led to the suggestion of giving hexamethylamine in meningitis and poliomyelitis. Alcohol was shown by Sclottmïller and Schumm to accummlate in the cerebrospinal fluid in even larger amounts than in the blood.

Of pathologic products, acetone, acetoacetic acid, lactic acid and hile have been found to pass over into the cerebrospinal fluid quite rearlily even when the meninges were not affected. I found the chlorides in the fluid to be increased in nephritis and the sugar to be increased in diabetes.

Sone of the experiments on the impermeability of the meninges and chorioid plexus are not entirely convineing because they deal with negative evidence. Tery frequently also the technic and method have been at fault. It is certain, howeror, that there is a vast difference be- 
tween the transmissibility of chemical and immune substances in health and in disease and although we may not know positively whether the meninges or chorioid plexus are entirely impermeable in health, we do know that they become permeable in disease-a fact of great importance in the genesis and also in the diagnosis and treatment of the diseases of the meninges.

\section{FUNCTION}

That the cerebrospinal fluid has a mechanic function there is no doubt. The fluid forms a water bed around the cord and brain and thus prevents the jarring from external trauma. The fluid also equalizes the pressure between the brain and the cord. Magendie, many years ago, pointed out the following:

"The cerebrospinal fluid which is barely mentioned in the classical works, not only fills out the empty spaces in the skull and spinal canal, it has a greater function, mainly to exert a continual and regulated pressure on the neuron masses."

However, a number of other functions are ascribed to cerebrospinal fluid. Mott believes that it is the function of the fluid to give up carbon dioxide and water to the blood and to take up oxygen and sugar. Cushing, and later Frazier, suggested that the fluid may be the medium of distribution of the active principle of the pituitary to the tissues of the central nervous system, which is essential to metabolism. Halliburton considers the fluid as a Locke modification of Ringer's solution. The sugar, as in Locke's solution, serves to supply the energy, the protein serves to repair the rear and tear resulting from the action of the nervous system, and the fluid as a whole acts as an ideal, plysiologic salt solution bathing the neurones and maintaining their osmotic equilibrium.

According to Gaskel the neural tube is a primitive digestive canal, and the cerebrospinal fluid a primitive gas- 
tric juice. Dandy calls attention to the gill-like appearance of the chorioid plexus, a fact that inclines him to believe that the chorioid plexus and the cerebrospinal fluid are concerned in respiration. Pettit and Girard hold that the fluid has an internal secretion. Still another theory of recent origin voices the opinion that the fluid serves as a destroyer of toxic substances introduced into the cerebrospinal nervous system.

Of the various theories advanced in regard to the function of the cerebrospinal fluid that of mechanic function has an unquestionable basis. All the other theories are open to objection of one kind or another; they lack in sufficient evidence. Mott's theory that the cerebrospinal fluids gives up $\mathrm{CO}_{2}$ and water to the blood seems illogical since the circulation of the fluid is entirely too slow and therefore inadequate to carry $\mathrm{CO}_{2}$ to the blood. Frazier's suggestion needs further confirmatory evidence. The theories of Dandy and of Gaskel do not appear at all plausible. As to the theory that the fluid destroys toxin, the objection may be raised that very few toxins are able to get into the cerebrospinal canal under normal conditions, as shown in the discussion on permeability. Of all the theories, the only one that has a firm basis is that of mechanical function.

\section{ORIGIN}

The question of the origin of cerebrospinal fluid is one that has engaged the attention of many physiologists and chemists, and even today the problem is far from settled, although attempts have been made to solve it through the aid of histology, chemistry, physiology, and pathology.

Carl Schmidt (1850) was the first to voice the opinion that cerebrospinal fluid was a secretion and not a transudate by virtue of the difference in the chemical composition of the blood and the fluid. Faivre (1854) also spoke of the intimate relation between the fluid and the chorioid plexus. 
Luschka, Schlaepfer, Yoshimura, Ernst, Kafka, Mott and Meek found the existence of vacuoles in the chorioid plexus, and all, with the exception of Meek, connected the globules with the secretion of cerebrospinal fluid. Mott examined the chorioid plexus of human beings soon after death and on staining with methylene blue, he found the cells of the chorioid plexus to contain many vacuoles. This, he believed, proved conclusively that the chorioid cells secreted some substance. He compared the epithelial cells of the chorioid with those of the lacrymal glands.

Physiologic evidence as to the secretion of the chorioid plexus was also brought forth by many observers. Kafka found that, after an injection of pilocarpine, the epithelial globules of the chorioid plexus were multiplied. Cavazzani showed that lymphagogues did not affect the cerebrospinal fluid. His observation that the alkalinity of cerebrospinal fluid was considerably less than that of the blood also led him to the conclusion that cerebrospinal fluid was a secretion. Cappelleti came to the same conclusion regarding the origin of the cerebrospinal fluid. $\mathrm{He}$ found that ethyl ether and pilocarpine increased the flow of the fluid, whereas atropin and hyoscyamin retarded the flow. Pettit and Girard found that the administration of pilocarpine, muscarin and ether to animals produced a marked increase in the secretion of the plexus. Dixon and Halliburton brought about an increase in the flow of the fluid by injecting chorioid extract. They claim that the chorioid plexus contains a hormone which when liberated into the blood becomes the precursor and regulating medium of the secretory activity of the plexus.

Interesting contributions to the chemical phase of the problem have been made by Schmidt, Polányi, Schottmüller and Schumm. The work of Schmidt has been mentioned. Polányi concluded, from the small protein content and the high molecular concentration of fluid in cases of hydrocephalus, that the fluid is not a transudate. Schottmüller 
and Schumm claimed that the fluid is not subordinate to the blood, as they had found the fluid in some cases to contain alcohol in as great and greater quantities than the blood. Leopold and Bernhard subscribe to the view of Cushing that the cerebrospinal fluid is secreted by the chorioid plexus on the ground that they were unable to find uric acid in the fluid in normal individuals.

Evidence from pathologic conditions, as to the secretive powers of the chorioid plexus has been fumished by other observers. Charles and Levy report a case of hydrocephalus in which there was hypertrophy of the chorioid plexus. Dandy and Blackfan occhded the aqueduct of Sylvius by a gelatine capsule and produced thereby an internal hydrocephalus. This would tend to show that the fluid is secreted above the aqueduct and most likely by the chorioid plexus. That part of the fluid might come from the ventricles themselves the work of Francini would indicate, as he noticed secretory phenomena of the ependyma cells of the ventricles after ether injections.

On the other hand, there are observations that would tend to show that cerebrospinal fluid is not a secretion. Mestrezat, on the basis of chemical analysis of the blood plasma and the cerebrospinal fluid, concluded that the fluid is not a filtrate, a transudate, or a secretion, but a dialysate of blood plasma produced by a passage through special epithelial cells. McClendon, on physico-chemical ground, claimed that the cerebrospinal fluid was an ultrafiltrate.

From the various data presented, one would be inclined to believe that the chorioid plexus is the seat of the origin of the cerebrospinal fluid. It is quite plausible to assmme that the plexus is located in the ventricles for some purpose and most likely for the secretion of the cerebrospinal fluid. Yet the evidence brought forward to prove these points is not altogether" ronvincing.

Mott's observation of the existence of vacuoles in the chorioid plexus, an observation that has been corroborated 
by Luschka, Findlay and Galeotti, does not necessarily indicate that the chorioid plexus secretes cerebrospinal fluid. Meek believes that the vacuoles are due to the melting of the fat in the epithelial cells of the chorioid through the action of such hardening fluids as alcohol and xylol, for chorioid cells which have not been subjected to alcohol and xylol do not show vacuoles. Pettit and Girard believe that these vacuoles are due to mechanical injury and to postmortem changes. Becht argues that secreting cells should not show vacuoles at all, but should be smaller than ordinary cells. He points out the fact that secreting cells in the parotid and other glands become smaller during the period of activity, whereas those of the chorioid plexus become larger. He notes other differences as well. While, in most glands, during the period of activity the cytoplasm is differentiated into an inner granular layer and an outer clear zone with well-defined nuclei, in the chorioid plexus, during activity, the very opposite takes place. The cytoplasm becomes differentiated into an inner clear and an outer granular zone and the nucleus can hardy be distinguished from the nucleus of the resting cells.

Cavazzani's evidence regarding the alkalinity of the cerebrospinal fluid does not hold good, because the methods used for the determination of the alkalinity were not the proper ones, and with newer methods, the acidity of the fluid is the same as that of the blood. As for the effect of pilocarpine in increasing the amount of cerebrospinal fluid, this does not necessarily show that the fluid is a secretion. The increase in the secretion can just as readily be attributed to the action of the drug on the blood vessels.

As for the chemical evidence brought forth by Polányi, is it not plausible to assume that the cerebrospinal fluid may come from the blood, and that the smaller content of protein in the fluid be due to the changes the fluid undergoes during the process of filtration? Schottmüller's observation that there may be a greater amount of alcohol in 
the cerebrospinal fluid than in the blood may be explained on the ground of slower absorption in the cerebrospinal canal than in the blood.

Until it is possible to remove the chorioid we shall not know conclusively whether the chorioid is the seat of the secretion of the cerebrospinal fluid. All that we can say at present with any degree of certainty is that there is convincing proof to show that the cerebrospinal fluid is produced above the aqueduct of Sylvius.

The fact that nearly all constituents of the blood are present in the cerebrospinal fluid, and that the physicochemical properties of the cerebrospinal fluid are practically the same as that of the blood, would make one believe that the cerebrospinal fluid is a direct product of the blood, most likely separated out by the chorioid plexus.

The data presented in this chapter may be summarized in the following points:

1. The cerebrospinal fluid is contained in the subarachnoid space of the brain and cord.

2. The fluid in the various ventricles is in direct communication with each other and with the fluid of the cord.

3. The cerebrospinal fluid has a circulation.

4. The rate of formations of normal fluids is unknown. So is the rate of absorption.

5. Absorption seemingly takes place by a process of diffusion from the subarachnoid of the cord and to a lesser extent from the subarachnoid of the brain. Some absorption also takes place by the lymphaties draining into the deep cervical glands, into the lymph vessels of the nose, perilymph spaces of the labyrinth and into the perineural sheets.

6. The cerebrospinal fluid, or rather the chorioid plexus, is not permeable, or very little so, under normal conditions.

7. The fluid exerts a mechanical function in that it equalizes the cerebrospinal pressure. The numerous other functions attributed to the fluid need further substantiation. 
8. The origin of cerebrospinal fluid is unknown. There is evidence pointing toward the theory that the chorioid plexus is the seat of origin of the fluid. There is also evidence pointing to the assumption that the fluid is a direct product of the blood. It is, therefore, plausible to assume that the chorioid plexus plays the role of separating the various constituents of the cerebrospinal fluid from the blood.

\section{Bibliography}

Achard and Ribot: Passage de l'iodure de potassium dans liquide eephalorachidean normal, Compt. rend. Soc, de biol., Paris, 1909, lxvi, 916.

Becht: Obserration on the Formation of Cerebrospinal Fluid, Proc. Am. Physiol. Soc., Boston, 1914, xxxii.

Blumenthal and Jacob: Zur Therapie des Tetanns, Berl. klin. Wchnselur., $1898, \mathrm{xxxr}, 1079$.

Böhm: Experimentelle Studien über die Dura Mater des Menschen und der Säugethiere, Virchows Areh. f. Path. Anat. 1867, xlvii, 218.

Cappelleti: Leconlement du liquide rerebo-spinale par la fistula Ceplalorachidienne en conditiones normales et sous l'influence de quelques, medieaments, Areh. ital. de biol., 1901, xxxvi, 299.

Carazzani: Contributo alla fisiologie del liquido cerebro-spinale, Centralbl. f. Physiol., 1901, xv, 216.

Crowe: On the Exeretion of Hexamethylenamin-(Utropin) in the Cerebrospinal Fluid and Its Therapeutie Value, Rull. Johns Hopkins Hosp., 1909, $\mathrm{xx}, 102$.

Cushing: Physiologische und Anatomische Beobachtungen üher deu intracraniellen Kreislauf, etc., Mitt. a. d. Grenzgeb. d. Med. u. Chir., 1902. ix. 773.

Cushing: Studies on the Cerebrospinal Fluid, Jour. Med. Research, 1914, xxxi, 1.

Dandy and Blackfan: Internal Hydroeephalus, Am. Jour. Dis. of Child., 1914 , viii, 406.

Dean: Intracranial Pressure, Jour. Path., 1892, i, 26.

Dixon and Halliburton: Cerebrospinal Fluid, I. Seeretion of the Fluid, Jour. Physiol., 1913, xlvii, 341.

Dixon and Hallibmton: The Rapidity of Alssorption of Drugs Introdueed Into the Cerebrospinal Fluid, Jour. Plysiol., 1912, xliv, Proc. Physiol. Soe., p. vii.

Fairre: Recherches sur la Structure du conarium et des plexus choroides ehez l'homme et chez les animaux, Compt. rend. l'Aead. d. se., 1854, xxxir, 424 .

Faive: Etude sur le conarium et les plexus choroides de l'homme et des animaux, Ann. d. se. nat. Paris, 1857, vii, 52; Gaz med. de Paris, 1854. No. 36.

Falkenheim and Naunyn: Ueber Hirndruck, Arch. f. exper. Path. u. Pharmakol., 1857, xxii, 261.

Findlay: The Choroid Plexus of the Lateral Ventricles of the Brain, Their IIistology, Normal and Pathological (in Relation Especially to Insanity), Brain, 1899, xxii, 161.

Frazier: The Cerelmospinal Flnid in Health and Discase. Jour. Am. Med. Assn., 1915, lxir, 1119. 
Geigel: Die Rolle des Liquor eerebralis bei der Cireulation im Schädel, Areh. f. d. ges. Physiol.; 1905, eix, 337.

Halliburton: Cerebrospinal Fluid, Jour. Physiol., 1889, x, 232.

Goldmann: Vitalfärbung am Zentralnervensystem; Beiträge zur physiopathologie des Plexus eloroideus und der Hirmhinte, Berlin, 1913.

Ifalliburton: Possible Funetion of the Cerebrospinal Fluid, Laneet, London, 1916 , ii, 779 .

Halliburton and Dixon: Choroid Plexus and Secretion of C. S. Fluid, Jour. Physiol., 1910, xl, 30.

Hektoen: Occurrence of an Isolated Antibody in the Cerebrospinal Fluid, Jour. Infect. Dis., 1913, xii, 1.

Hill: The Physiology and Pathology of the Cerebral Circulation, London, 1896; Allbutt's System of Medicine, 1899, vii, 239.

Kafka: Ueber die Bedingungen und die praktische und theoretische $\mathrm{Be}$ deutung des Vorkommens hammelblutlosender Normalambozeptoren und des Komplements im Liquor cerebrospinalis., Zeitsehr. f.d. ges. Neurol u. Psych., 1912, ix, 132.

Knoll: Über die Druckschwankungen in der Cerebrospinalflüssigkeit, Sitzungsheriehte der Akad. d. Wissenschaft, 1886, xeiii, 227.

Kolmer and Sekiguchi: Experiment on Passive Transfer of Antibodies from the Blood to the Cerebrospinal Fluid, Jour. Immunology, 1918, iii, 101.

Kramer: The Function of the Choroid Gland and Its Relation to the Toxicity of Cerebrospinal Fluid, Jour. Am. Med. Assu., 1911, lvi, 265.

The Circulation of Cerebrospinal Fluid and Its Relation to the Pathogenesis of Poliomyelitis, New York Med. Jour., 1912, xev, 1532.

Lewandowsky: Zur Lehre von der Cerebrospinalflüssigkeit, Ztschr. f. klin. Med., 1900, xl, 480; Neurol. Centralbl., 1901, p. $4+7$.

Leyden: Beitrage und Untersuchungen zur Physiologie und Pathologie des Gehirns, Virchows Areh., 1866, xxxvii, 519.

Luschka: Zur lehre von der Secretionzelle, Arch. f. Physiol. Ifeilk., 1854, xiii, 1.

Luschka: Die Adergeflechte des mensehlichen Gehirns, Berlin, 1855.

Luschka: Ueber die Communication der vierien Hirnhöble mit dem Subarachnoidelraume, Zeitselnift fiir rationelle Mediein, 1859, Dritte Reihe, vii, 68.

Magendie: Reeherehes physiologiques et eliniques sur le liquide ecphalorachidien ou cerebro-spinal, Paris, $18+2$.

Mare, See: Sur la communieationes des avites rentrienlares de l'encephale, Rev. mens. de Chir., 1878-1879.

MeClendon: The Formation and Composition of the Cerebrospinal Fluid, Jour. Am. Med. Assn., 1918, Ixx, 977.

Meek: A Study of the Choroid Plexus, Jour. Comp. Neurol. und Psychol., 1907, xvii, 286.

Mott: Cerehrospinal Fluid, Lancet, London, 1910, ii, 1; Brit. Med. Jour., 1904, ii, 1554.

Olmer and Tian: Permeabilite des meninges normales an salieylates de lithium, Compt. rend. Soc. de biol., 1909, lxvi, 894 .

Pettit and Girard: Sur la function Secretoire et la morphologie de plexus ehoroides, Areh. d' Anat. Miero., 1902-1903, v, 213.

Rous: Clinieal Studies of the Cerehrospinal Fluid, Am. Jonr. Med. Se., 1907 , exxxiii, 567.

Reiel:ardt: Zur Entstehung des Hirndrueks bei Hirugesehwiilsten und anderen Hirnkrankheiten und iiber eine hei diesen zil beobachtende besondere Art der Hirnsehwellung, Deutsch. Ztsehr. f. Nervenh., 1905, xxviii, 306. 
Schlaepfer, V.: Ueber den Bau und die Funktion der Epithelzellen des Plexus ehoroideus in Beziehung zur Granuladehr und mit besondere Berüeksichtigung der Vitaleı Färbungsmethoden, Beitr. z. path. Anat. u. z. allg. Path., Suppl. vii, 101.

Schmidt, Carl: Charakteristik der epidemischen Cholera, Leipzig und Milan, $1850,148$.

Sehmorl: Liquor eerebrospinalis und Ventrikelflüssigkeit, Veŕhandl. d. deutsch. path. Gesellsch., Er langen, 1910.

Sicard: Les injections sous-arachnoidiennes et le liquide cephalo-rachidien dans les maladies mentales, Bull. de la Soe. med. des hop. de Paris, June, 1901.

Spina: Untersuchungen über die Resorption des Liquors bei normalen und erhöhten intrakraniellen Druck., Arch. f.d. ges. Physiol., 1901, 1xxxiii, 120.

Spina: Experimentelle Beiträge zur Kenntniss der Hyperamie des Hirns, 1898, Wien. med. Bl., "247.

Spina: Über den Einfluss des hohen Blutdruekes auf Cerebrospinal Flüssigkeit, Pflugers Arch., 1900, $1 \times x x, 370$.

Sundwall: The Choroid Plexus with Special Reference to Interstitial Granular Cells, Anat. Rec., 1917, xii, 221.

Weed: Studies on the Cerebrospinal Fluid, Jour. Med. Research, 1914, xxxi, 1.

Weil and Kafka: Über die Durchgangikeit der Meningen, besonders bei der progressiven Paralyse, Wien. klin. Wehmsehr., 1911, xxiv, 335.

Weil and Kafka: Weitere Untersuehungen iiber den Hämolysingehalt der Zerebrospinalflüssigkeit bei akuter Meningitis and progressiver Paralyse, Med. Klin., 1911, vii, 1314.

Yoshimura: Das histochemisehe Verhalten des mensehliehen Plexus chol'oideus, Obersteiner's Arbeiten, 1910, xviii.

Zaloziecki: Zur Frage der Permeabilität der Meningen insbesondere Immunstoffen gegenüber, Deutsch. Ztsehr. f. Nerronh., 1913, xlvi, 195.

Ziegler: Beitrag zur Anatomie des Plexus chorioideus Deutsch. Ztschr. f. Chir., 1902, Ixvi, 509. 


\section{CHAPTER III}

\section{METHODS OF OBTAINING CEREBROSPINAL FLUID FRON THE LIVING BODY}

Before the day of spinal puncture the removal of cerebrospinal fluid from the body was effected with a great deal of difficulty. The usual method of removing cerebrospinal fluid from dogs was hy means of a fistula between the occiput and the atlas. From human beings cerebrospinal fluid was obtained through an aceidental flow of fluid from the nose or ears. There are about twenty such cases on record. Another way of obtaining cerebrospinal fluid from the living body, but one used only very rarely, was an open operation either on the head or on the vertebral column.

At present there are two reliable methods in use for the removal of cerebrospinal fluid from man or animal. One is spinal puncture, nore properly called, lumbar puncture, and the other is cranial or ventricular puncture. Both procedures are comparatively simple and can be carried out under ordinary conditions at the hospital or at home. Lumbar puncture is preferable for many reasons. We shall, therefore, discuss it more exhaustively.

\section{LUMBAR PUNCTURE}

The first lumbar puncture by Quincke in 1891 was done for therapentic purposes. Since his time, however, we have learned a great deal about the value of lumbar puncture for diagnostic as well as for therapeutic purposes. Therapentically, lumbar puncture is done for the relief of increased intracranial pressure as in hydrocephalus, delirium tremens, eclampsia, encephalitis and other con- 
vulsive conditions. Of great value is lumbar puncture for the purpose of injecting serum in cases of epidenic meningitis, and for the Swift-Ellis treatment of syphilis. Lumbar puncture is also done by some for the relief of general erlema in cases of nephritis. Recently, J. M. Brady re-

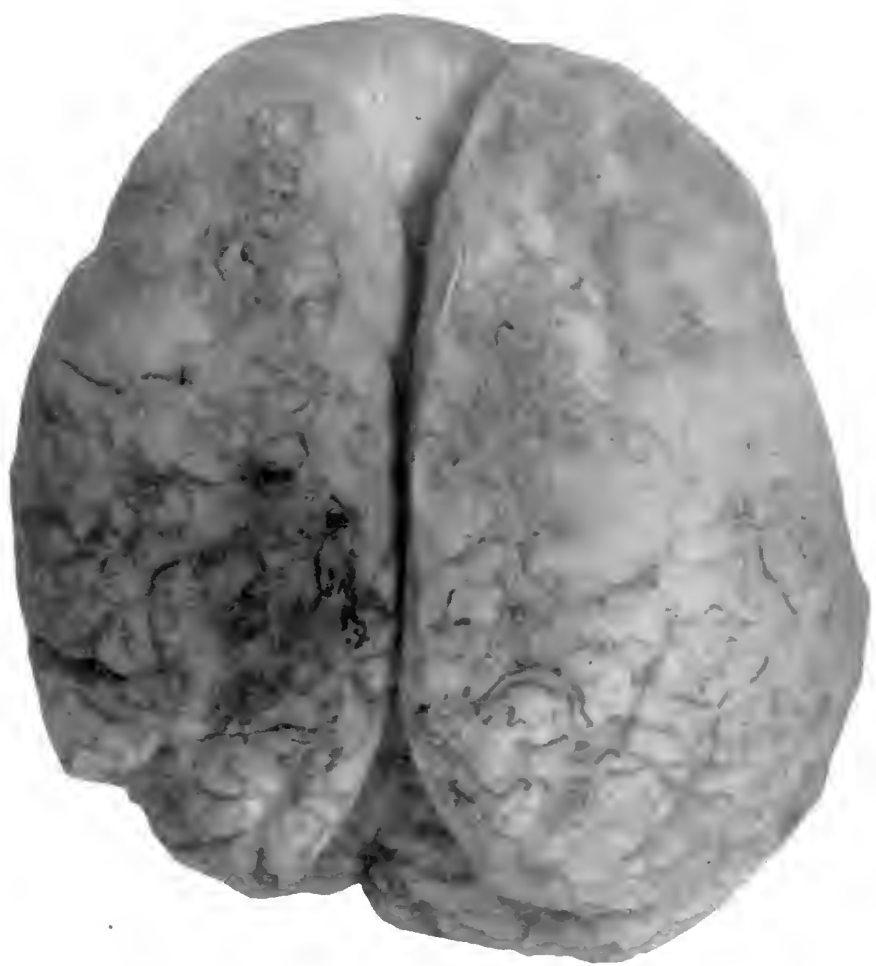

Fig.8.-Specimen illustrating the importance of spinal puncture for diagnostic purposes. S. C. entered the hospital with symptoms of pnemmonia and with marked cyanosis. At first sight there seemed to be no indication for a spinal puncture, but when convulsions set in, a puncture was done. The fluid withdrawn was very turbid and showed preumococci in direct smear as well as in culture. The postmortem slowed a well-defined exulate of the meninges, the exulate containing many pneunococci.

ported three cascs of meningeal hemorrhage which recorered after lumbar puncture. Cure by spinal puncture has also been reported in two ases of diabetes insipidus. As a general rule, therefore, a spinal puncture should be made 
in all cases showing signs of increased intracranial pressure.

Diagnostically, lumbar puncture is of great value in cerebrospinal lues, hemorrliage of the brain, tumors of the cord, poliomyelitis, ete. It is particularly valuable in the diagnosis of all forms of meningitis and poliomyelitis.

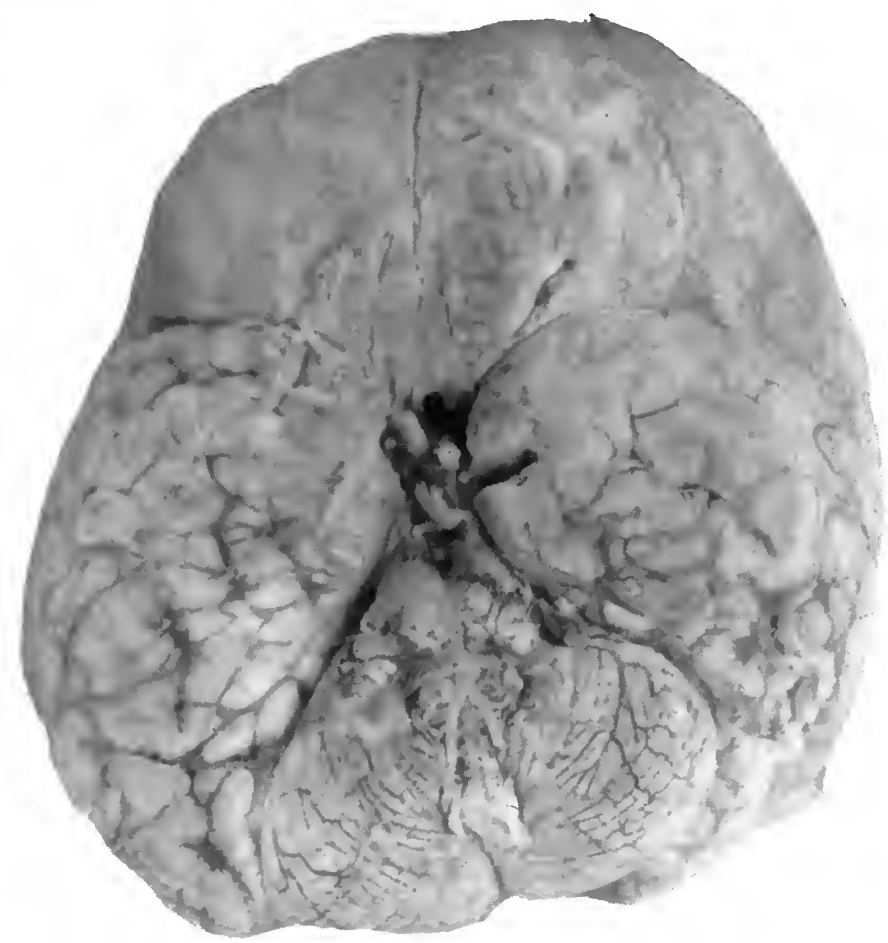

Fig. 9.-Opposite view of Fig. 8. (See Fig. 8 for description.)

The following cases are cited to show how important a diagnostic measure spinal puncture may be:

S. C., entered the hospital with srmptoms of pneumonia and cyanosis. The lung findings were indefinite. There was very little rigillity of the neek and no other symptoms pointing to a meniugitis. At first sight there seemed to be no indication for a spinal puncture, but when convulsions set in a fmoncture was male. The fluid withlrawn was turbid and showed pnemmococei in smear and eulture. The postmortem showed the lungs to be congested, but no pneumonia. The ecrebrum, however, was covered 
with a gelatinous, greenish gray, purulent material several millimeters thick and very firm; the exudate was located on the upper and lateral surfaces of the brain. (Figs. 8 and 9.) The smear's as well as the cultures showed gram-positive eoeei.

Although in this case not much could be done therapeutically even if the process had been recognized earlier, the spinal puncture was of great value. It served to establish a positive diagnosis in a case in which a meningeal exudate existed with few if any of the meningeal symptoms that usually accompany such a condition.

The case that follows illustrates even more vividly the importance of lumbar puncture:

S. W., ten years old. Siek for five days. Complained of pain in lumbosacral region, and also in the right hip, radiating to the sole of the foot at the time; oceasionally there was pain in the left shoulder. When first seen the temperature was $102^{\circ} \mathrm{F}$. There was tenterness to touch in the lumbosaeral and gluteal regions, slight rigidity of the neek, slight Kernig and eontralateral Brudzinski signs. The diagnosis by several physieians was neuritis. On lumbar puncture a very turbid fluid was obtained under great pressure. Bacteriologie examination showed meningoeocei and several hundred cells per culfic millimeter. All globulin tests were positive. The patient was given several doses of antimeningococeus serum and recovery followed.

In this case lumbar puncture was a life-saving measure. In the next case meningitis could hardly have been discovered without lumbar puncture as the general symptoms were so indefinite.

F. R., aged cight months. Sick one day with fever and constipation. Had attack of cyanosis for a few minutes. General examination was negative. Lumbar puncture was done and to the great surprise of the physicians, the fluid was found very turbid and full of meningococei.

These cases are but few of a great number coming under my observation that illustrate the extreme importance of lumbar puncture.

There are very few counterindications to lumbar puncture. In cases of tumors of the cerebrum and cerebellum, it is true that puncture is not so safe as under ordinary conditions. Even then, however, a lumbar puncture may be done with little trepidation if the pulse and reflexes of 
the patient are watched and if the amount and pressure of the cerebrospinal fluid are closely observed.

\section{Untoward Effects of Lumbar Puncture}

Cases of death from spinal puncture have been reported. These, however, usnally occurred in cases of brain tumor, and death in most instances was attributable to shock. Of the many hundreds of punctures that have come under my observation, I saw only one case of deatlu during puncture. Of other dangers attending spinal puncture the following may be mentioned: Piercing of the aorta, injury to the nerves, and breaking of the needle.

As to piercing of the aorta, it must be said that this is a very rare occurrence, and when it does happen it is due to poor judgment on the part of the operator as to the depth to which the needle should be introduced.

Injury to the nerves is a complication that can easily be averted if the puncture is made at a low level in the lumbar region, preferably between the third and fourth vertebre.

Breaking of the needle may result from undue force. If the needle is broken directly beneath the skin, it is best to incise the skin and remove it. If it is broken deeper, however, which is generally the case, it is best to leave it alone for a while. If no complications occur in several days, it is advisable to leave the needle in. If severe pain or suppuration occurs, a radical operation should be done and the needle removed. There are some less severe complications that may follow lumbar puncture. The most important of these are headache following the puncture, pain of the lower extrenities, and edema of the skin, especially after repeated punctures.

The cause of headache after lumbar puncture is a matter of speculation. It is generally attributed to the removal of too great an amount of fluid at one sitting. Headache, however, sometimes follows even after the removal of a small amount of fluid. MacRobert has recently sug- 
gested that headache following lumbar puncture may be due to the nonclosure of the puncture hole in the arachnoid. The arachnoid tissue in a case of this kind, the author says, is pulled through the dural opening when the needle is withdrawn. This results in prolonged epidural leakage and in the lack of support of the medulla, a condition which gives rise to severe headache. This explanation sounds plausible although it requires corroboration before we can accept it. When headache does occur after lumbar puncture the best method of treatment is to put the patient flat on his back for several hours. Occasionally it becomes necessary to resort to drugs for relief of the condition. Sodium and potassium bromide or salicylates may then be employed. Rarely is it necessary to use stronger remedies than these.

Pain of the extremities after lumbar puncture is usually due to injury of one of the filaments of the cauda equina. Rest in bed is usually all that is necessary to relieve this condition.

Edema of the skin in the lumbar region is an infrequent complication. I have seen it in but two cases and then after repeated punctures. When it does occur in infants, the lumbar region should be given a rest and if necessary to introduce sermu, it should be injected into the ventricles of the brain instead. Then edema of the skin occurs in adults, warm cloths should be applied to the edematous region and serum given intravenously until the edema subsides, after which intraspinal introduction of serum may be resumed.

In general, lumbar puncture when indicated should not be feared because of complications.

\section{Technic of Lumbar Puncture}

To do a spinal puncture properly one must take into consideration a number of important factors.

1. The anatomic relations of the cord and its membranes at the lumbar region. 
The cord, in the adult, ends at the first lumbar vertebra, and in the child, at the second vertebra, seldom at the third.

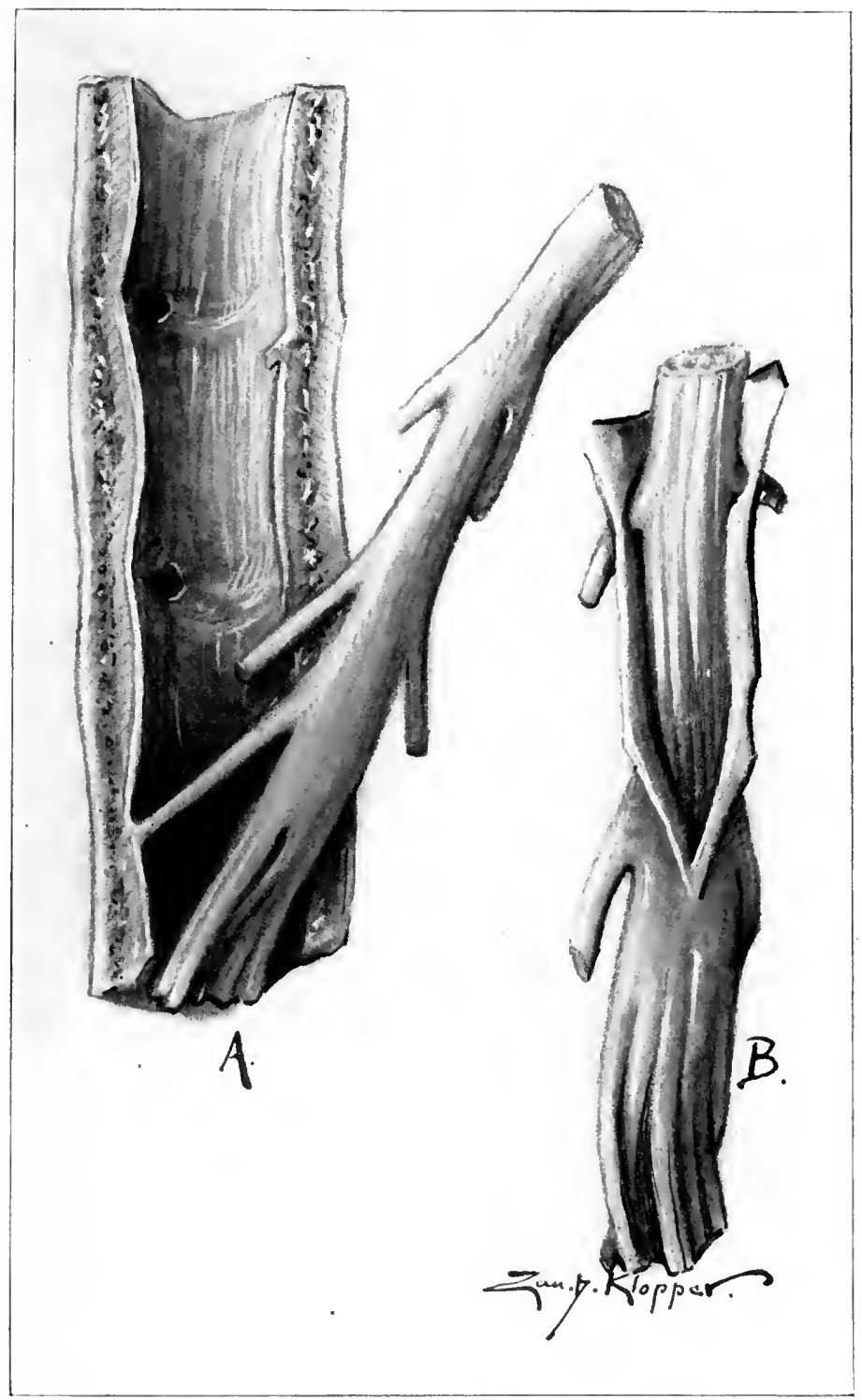

lig. 10.- Section of cauda equina of a dog. $A$, Membranes intact; $B$, Dura and arachnoid eut open. 
The cord has its ending in the conus medullaris, the apex of which is continnous with the filum terminalis. Throughout its entire length the cord is surrounded by three membranes, the dura, the arachnoid and the pia. The accompanying drawing (Fig. 10) shows the membranes surrounding the cord and the cauda equina in a dog. The same relations also hold good in man.

2. The structures encountered between the skin and the cord, which are as follows from without inward:
(a) Skin.
(b) Subcutaneous fascia.
(c) Fat.
(d) Deep fascia.
(e) Multifidus muscle.
(f) Vertebral arches.
(g) Ligamentum flavum.
(h) Dura.
(i) Arachnoid.

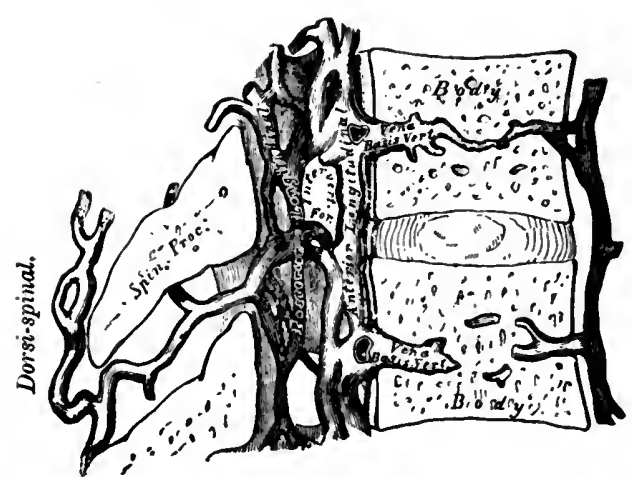

Fig. 11.-Plexus of veins, the puncture of which is responsible for blood obtained during spinal puncture. (Gray's Anatomy.)

3. The plexus of veins on the posterior wall of the body of the rertebra (Fig. 11). If these are struck by the spinal puncture needle the resultant fluid is bloody.

Another matter for consideration in lumbar puncture is the position of the patient, particularly if the patient is a child. While in an adult the physician may do the 
puncture with the patient in either the sitting or reclining position, in a child he should not attempt the puncture with the patient in any but a reclining posture. In all cases of meningitis the patient should be in the lying posture when the puncture is performed. I always made it a practice to puncture with the patient in a recumbent position. The patient may be placed on either right or left side, the right being the preferable one for the patient, who should be arched so as to widen the intervertebral space.

The skin should be prepared very carefully for the puncture. Soap and water, alcohol and iodine should be used for cleansing purposes. Rubber gloves should be worn and all other aseptic precautions must be taken to minimize the danger of infection of the meninges. As a rule neither a general nor a local anesthetic is called for in doing spinal puncture. It may be necessary to resort to an anesthetic in maniacal cases, although I have not encountered a single case in which I could not get along without it. Sophian suggests that the patient be given water to drink during lumbar puncture. He found that this procedure made an anestlietic unnecessary. As a rule, however, even this is not necessary.

\section{The Spinal Puncture Needle}

Regular spinal puncture needles are now made measuring from 7 to $9 \mathrm{~cm}$. in length and 0.6 to $1.2 \mathrm{~mm}$. in thickness with a stylet to fit the needle (Fig. 12). Some needles are made with valves for the measurement of the pressure of the fluid. Most needles on the market are made of steel, although there are some nickel-plated ones and some made of platinum iridium. If meningitis is not suspected a needle with a small lumen will do, but if there is the slightest suspicion of meningitis a needle with a large lumen should be used. In children it is always best to use a needle with a large lumen, so that in case the fluid is thick it will not 
clog up the needle. The needle should be boiled and cooled before using. It should also be examined very closely for rust.

Quincke's advice that the needle be introduced directly in the midline in children and 5 to $10 \mathrm{~mm}$. to the side in
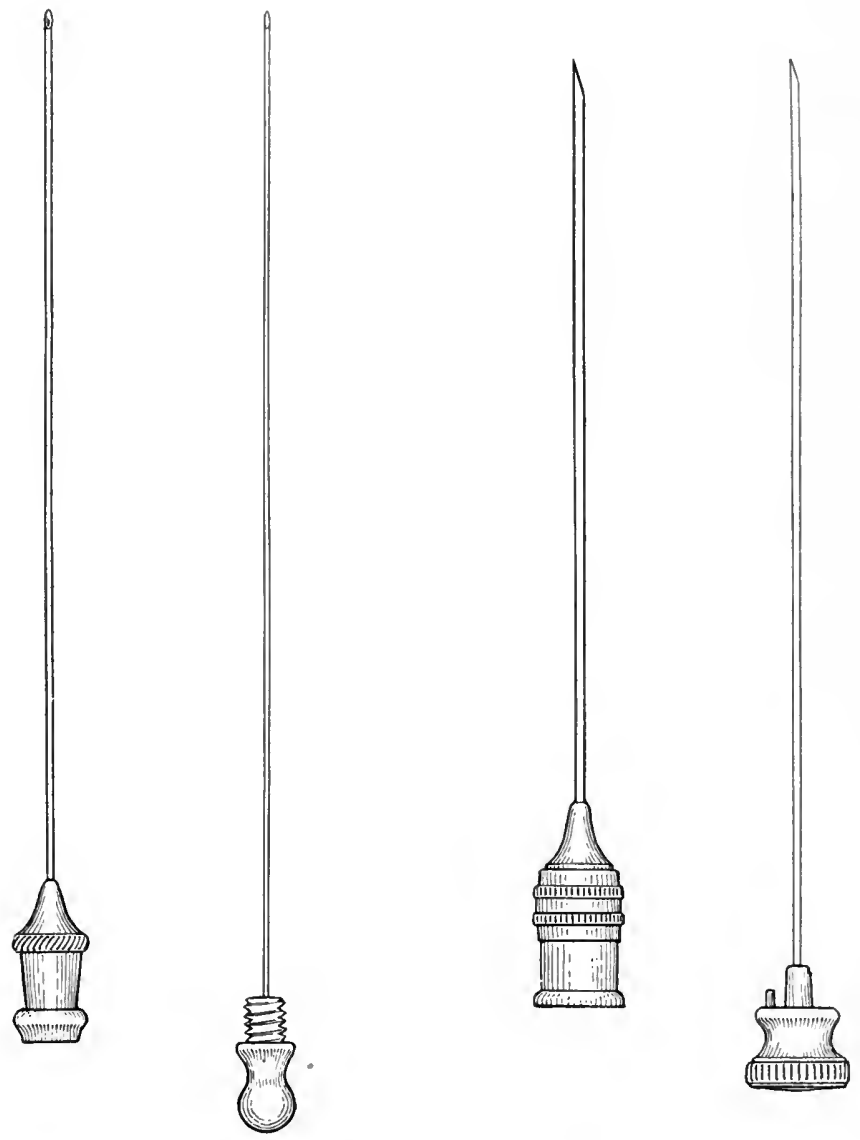

Fig. 12.-Various types of Iumbar puncture needles.

adults, holds good to this day. If the needle is inserted in the third or fourth interspace, cerebrospinal fluid may be withdrawn without injury to the nerves. A good landmark for the guidance of the needle may be made by drawing 
a horizontal line through the vertebral column across the crests of the ilium. I usually draw this line with tincture of iodine on a swab. This strikes the interspace between the third and fourth vertebra.

It is often quite difficult to feel the intervertebral space in fat people and in very young children. Becanse of this difficulty extreme care is necessary in cases of this kind.

"How much of the needle should be introduced into the canal?" is one of the first questions that greets the inexperienced operator. In consulting literature on the subject $I$ found very little information about the length of the needle, the only tabulated data available being by Quincke, who, however, cites only a few cases.

\section{TABLE I}

Measurements by Quincke

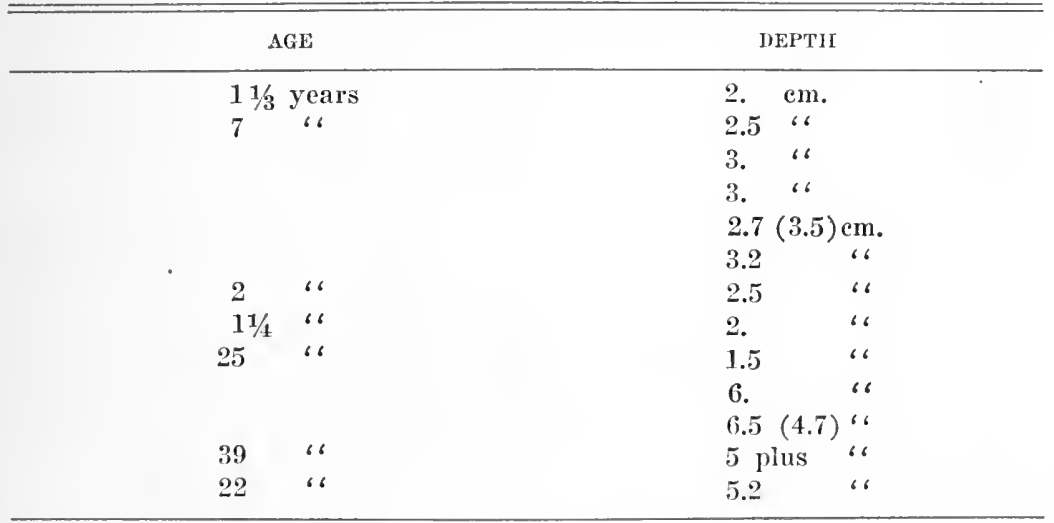

I measured the length of the needle in a series of several hundred cases, adopting the following procedure: When ready to remove the needle from the spinal canal after obtaining a good flow of fluid, I grasped the needle close to the patient's skin between the thrmb and index finger, pulled it out, and measured it from the point held by the fingers to the tip. 
TABLE II

Mesistremexts of Needle in Childrex

\begin{tabular}{|c|c|c|c|c|c|}
\hline NAME & & $A G E$ & LENGTH & $\mathrm{OF}$ & NEEDLE IN CM. \\
\hline R. R. & 4 & months & & & 2.0 \\
\hline R. D. & 5 & "6 & & & 2.2 \\
\hline A. J. & 6 & “ & & & 2.0 \\
\hline A. S. & 6 & “" & & & 2.3 \\
\hline I. G. & 6 & "، & & & 2.5 \\
\hline E. H. & 7 & "، & & & 2.5 \\
\hline E. G. & 8 & “ & & & 2.4 \\
\hline E. G. & 9 & “ & & & 2.2 \\
\hline A. C. & 12 & “ & & & 2.2 \\
\hline S. K. & 12 & “ & & & 2.0 \\
\hline A. $x$. & 14 & “ & & & 2.8 \\
\hline A. $N$. & 14 & “ & & & 2.5 \\
\hline J. S. & 21 & "، & & & 3.5 \\
\hline М. МГ. & 22 & “، & & & 3.0 \\
\hline T. K. & 2 & years & & & 2.7 \\
\hline T. $\mathrm{K}$. & 2 & "6 & & & 2.1 \\
\hline R. P. & 2 & “" & 7 mos. & & 2.4 \\
\hline F. W. & 3 & “، & & & 4.0 \\
\hline J. M. & 3 & “، & & & 2.0 \\
\hline M. H. & 3 & "“ & & & 2.8 \\
\hline м. К. & 3 & ، & & & 2.9 \\
\hline MeNI. & 4 & " & & & 3.2 \\
\hline H. & 4 & “" & & & 2.9 \\
\hline P. O. & 4 & “، & & & 2.8 \\
\hline W. J. & 5 & “" & & & 3.2 \\
\hline R.L. & 6 & “" & & & 3.0 \\
\hline A. G. & 7 & “ & & & 4.0 \\
\hline G. Mr. & 8 & " & & & 3.5 \\
\hline S. L. & 8 & “ & & & 3.5 \\
\hline S. B. & 9 & “6 & & & 3.7 \\
\hline S. B. & 9 & “" & & & 3.4 \\
\hline S. $B$. & 9 & “6 & & & 4.0 \\
\hline E. D. & 9 & “، & & & 3.8 \\
\hline R. A. & 10 & “ & & & 3.6 \\
\hline L. G. & 12 & “" & & & 3.2 \\
\hline L. G. & 12 & “ & & & 3.6 \\
\hline
\end{tabular}

Table II gives the measurements of the needle made in children from four months to twelve rears of age and Table III gives the measurements in adults of various ages. I include here but a few of the several hundred of measurements made. In cases in which the results were similar I tabulated but one measurement; in cases of the same age 
TABLF III

Measurements of Needle in Adults

\begin{tabular}{|c|c|c|c|c|}
\hline NAMF & & $A G E$ & LENGTH & OF NEEDLE IN CM. \\
\hline S. G. & 16 & years & & 5.4 \\
\hline T. R. & 20 & 6 & & 4.8 \\
\hline C. & 25 & “ & & 5.0 \\
\hline P. & 26 & “6 & & 5.3 \\
\hline K. & 27 & " & & 5.8 \\
\hline Mrs. D. & 29 & “" & & 4.9 \\
\hline L. & 29 & "6 & & 5.5 \\
\hline A. C. & 30 & “6 & & 5.6 \\
\hline E. & 30 & “ & & 4.5 \\
\hline D. & 30 & "6 & & 5.4 \\
\hline H. & 30 & "6 & & 5.2 \\
\hline E. & 30 & “ & & 5.8 \\
\hline A. C. & 30 & " & & 5.6 \\
\hline T. & 31 & " & & 5.5 \\
\hline J. T. & 31 & “ & & 10.0 (very fat) \\
\hline Mrs. 1. & 32 & ، & & 5.1 \\
\hline A. C. & 33 & “ & & 4.1 \\
\hline I. N. & 33 & “ & & 5.1 \\
\hline M. & 34 & ‘ & & 5.1 \\
\hline $\mathrm{P}$. & 34 & “6 & & 5.2 \\
\hline S. G. & 34 & " & & 4.5 \\
\hline S. & 34 & 6 & & 4.6 \\
\hline $\mathrm{M}$ & 35 & "6 & & 5.7 \\
\hline M. & 35 & “ & & 4.8 \\
\hline R. & 35 & "، & & 5.5 \\
\hline H. & 36 & $" 6$ & & 4.1 \\
\hline M. W. & 37 & “ & & 5.3 \\
\hline I. G. & 37 & "6 & & 5.5 \\
\hline D. & 37 & “ & & 5.9 \\
\hline S. S. & 38 & “ & & 5.0 \\
\hline J. J. & 39 & “ & & 7.0 (very fat) \\
\hline s. & 40 & 66 & & 6.0 \\
\hline$P$. & 40 & " & & 6.4 \\
\hline M. & 40 & "6 & & 4.9 \\
\hline$W$ & 40 & " & & 5.0 \\
\hline R. & 40 & ‘ & & 6.4 \\
\hline $\mathrm{E}$. & 42 & “ & & 5.0 \\
\hline W. & 43 & "6 & & 6.3 \\
\hline K. & 43 & “ & & 4.5 \\
\hline M. B. & 44 & " & & 4.9 \\
\hline J. A. & 44 & "6 & & 5.8 \\
\hline W. & 44 & “ & & 5.5 \\
\hline $\mathrm{s}$. & 45 & " & & 5.5 \\
\hline F. & 46 & “ & & 4.9 \\
\hline Mrs. B. & 48 & $\because$ & & 4.9 \\
\hline M. & 48 & 16 & & (Cont'd p. 62) \\
\hline
\end{tabular}


TABLE III-Cont'd

Measurements of Needle in Adults

\begin{tabular}{|c|c|c|c|}
\hline NAME & & $\mathrm{AGE}$ & LENGTH OF NEEDLE IN CM. \\
\hline I. & 48 & years & 5.5 \\
\hline S. & 52 & 6 & 5.2 \\
\hline R. & 53 & "6 & 5.1 \\
\hline B. & 53 & 6 & 10.0 (very fat) \\
\hline B. & 53 & “6 & 6.0 \\
\hline $\mathrm{H}$. & 54 & "6 & 5.2 \\
\hline $\mathrm{W}$. & 55 & “ & 5.3 \\
\hline s. & 55 & "6 & 6.7 \\
\hline D. & $5 \vec{\imath}$ & 6 & 5.4 \\
\hline A. & 57 & "6 & 5.6 \\
\hline M. R. & 60 & "6 & 4.1 \\
\hline F. & 60 & 16 & 5.9 \\
\hline $\mathrm{K}$. & 60 & 6 & 6.0 \\
\hline B. & 60 & 6 & 5.9 \\
\hline S. & 61 & 66 & 5.9 \\
\hline $\mathrm{W}$. & 65 & "6 & 8.0 \\
\hline
\end{tabular}

where the measurements were different several measurements are tabulated. In some cases the results of several measmrements are given for the same patient to show the length of the needle at different punctures. As is seen from the tables the needle requires a length varying from 2.0 to $4.0 \mathrm{~cm}$. in children up to twelve, and a length varying from 4.1 to $10 \mathrm{~cm}$. in people over sixteen years of age. The variations in the adult may be attributed to several factors. Physique is one; the direction taken by the operator in inserting the needle is another, an oblique insertion naturally requiring a greater length of needle than a straight insertion. The location of the interspace is another factor, the higher the point of insertion, the greater being the length of the needle required. Some clinicians use as the place of introduction the space between the second and third lumbar vertebrx, others the space between the first and second. It is also interesting to note that the length of needle inserted varies at different punctures in the same patient. 'This is due to the fact that the canal is quite wide and that fluid may be removed whether the nee- 
dle is near the anterior or near the prsterior surface of the canal.

When the needle passes the dura, a snap is felt. The stylet should then be removed and the fluid allowed to run into the pressure apparatus or into tubes.

\section{Reasons for Failure to Obtain Fluid}

There are times when no fluid can be obtained in spite of all efforts. Among the factors responsible for the failure to obtain fluid, the most important are the following:

1. The needle may not have been inserted far enough into the canal.

2. The needle may have been introduced too far into the canal. In such cases the material exuding from the intervertebral dise may elog up the needle.

3 . The presence of blood in the fluid.

The presence of blood is by far the most common cause of failure in lumbar puncture. It may be due to hemorrhage of the brain or to piercing some vein of the plexus in the spinal canal. If the presence of blood in the fluid is due to the striking of the plexus of veins, the exnding fluid has the color of fresh, venous blood. If it is due to a hemorrhage, the blood in the fluid is a dark red, and if the hemorrhage is one of long standing, clotted particles of blood may be seen clinging to the needle or coming out of the lumen.

If no fluid is obtained the stylet should be reintroduced into the needle to clear it of any particles that may be clogging the lumen, and it should then be withdrawn again. If there is still no sign of fluid the needle should be moved a little deeper or withdrawn slightly. If fhid is still not forthcoming, the needle should be removed and reintroduced one space higher. If after this procedure there is still no fluid an ethylchloride spray applied to the thigh may accelerate the flow. If after repeated trials no fluid escapes, one may ascertain whether the spinal canal has 
been reached by the following method: The first needle is left in its original position, and a second needle is introduced one space liigher. A solution of sterile salt is injected into the higher needle. If the first needle is in the canal, the salt solution will flow out of it. When this happens it indicates that in all probability no fluid can be obtained. As a rule one should be careful about pronouncing a puncture dry. A failure to obtain fluid may nearly always be attributed to some fault in the technic.

If the case shows symptoms of meningitis in spite of the fact that no fluid can be obtained by the spinal route, it may concern a basilar meningitis in which it often happens that the connection between the brain and cord becomes clogged. In such a case ventricular puncture should be (lone. The technic of rentricular puncture will be deseribed later.

\section{Pressure}

The measurement of the pressure of the cerebrospinal fluid is very significant from the standpoint of diagnosis as it furnishes an almost immediate clew as to the existence of a pathologic condition. It should, therefore, be used in connection with lumbar puncture whenever possible.

Various forms of apparatus have been described for the determination of the cerebrospinal fluid pressure. Quincke used an ordinary glass tube with a one-millimeter bore bent at the top, and an ordinary tape to measure the pressure: an arrangement like the one used by Quincke may be made at any laboratory by taking heavy glass tubing of one-millimeter bore, bending it at right angles below, and connecting it with hard rubber of one-millimeter bore to a tip fitting into an ordinary spinal puncture needle. The point to which the fluid reaches can be marked off and the height can then be measured on a slide or with a tape measure (Fig. 13). I used this arrangement for some time, but although it is of ralue, it is not accurate enough. The 
disadvantage of the Quincke apparatus lies in the fact that it takes too much time to attach the glass tubing to the needle. It frequently happens that the pressure of the

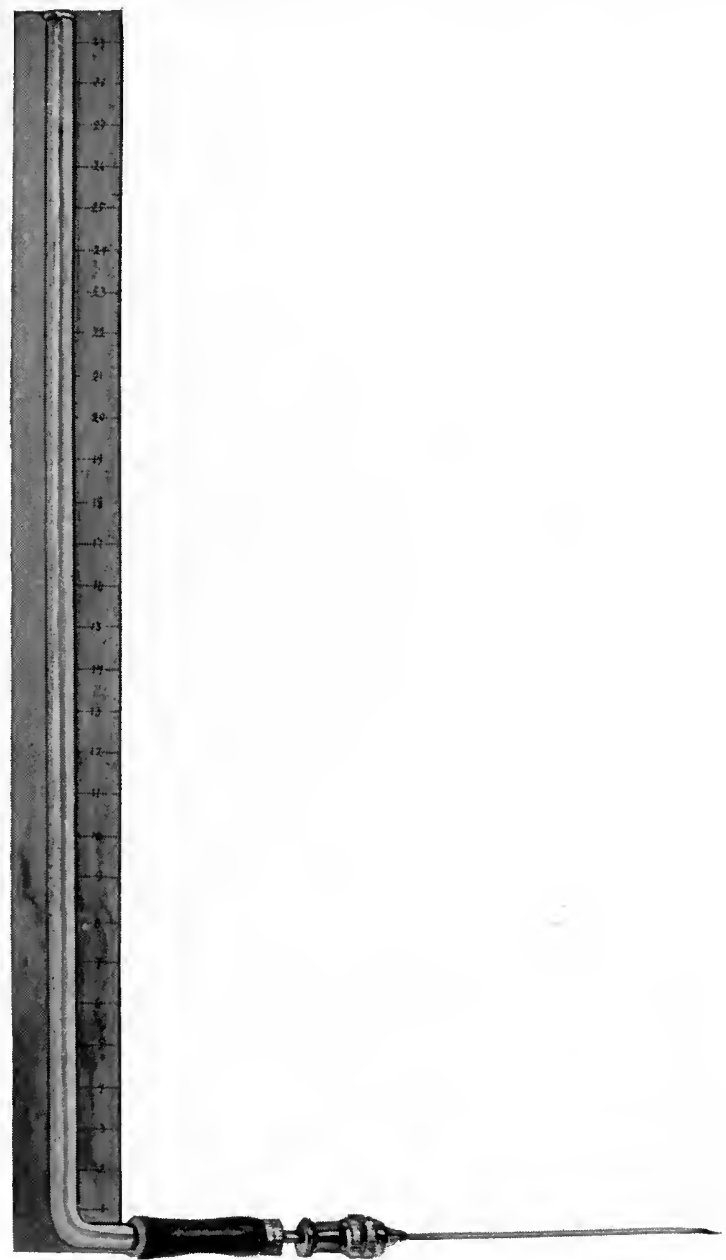

Fig. 13.-Modified Quincke apparatus for measuring the cerebrospinal fluid pressure.

fluid is so great that as soon as the stylet is removed from the needle, the fluid bursts out, and several cubic centimeters of fluid are lost before the tip of the pressure apparatus can be connected to the needle. In this way the 
real pressure value can not be ascertained, as it is known that once a few cubic centimeters of fluid are removed, the original cerebrospinal pressure is not maintained.

Several other types of apparatus have been described. One is by Kroenig, utilized principally for the purpose of withdrawing fluid from suspected cases of brain tumor. The caliber of the measuring tube is so small, that it only takes a few drops to fill it, and when the column of fluid shows no oscillation, no more fluid should be withdrawn.

Some authors have used a mercury manometer. In normal cases, however, I have found the pressure to be too small to be measured in millimeters of mercury, as each millimeter of mercury corresponds to $13 \mathrm{~mm}$. of water. Thus, for instance, when the pressure of the fluid is $65 \mathrm{~mm}$. of water, the mercury manometer registers only four and one-half or five, making too great an error in the reading. As for the objections raised against the ordinary one $\mathrm{mm}$. bore that it is too small and that it exerts capillary traction, it must be said that after all since the value of pressure reading lies in the comparison between the normal and pathologic capillary traction is not a great factor.

In my experiments on pressure I have been using an apparatus which allows no loss of fluid and which has the added advantage of being simple.

The apparatus (Fig. 14) consists of a specially devised needle and a glass manometer.

The needle is the ordinary, medium-sized, spinal puncture needle with a short piece of glass mounting. The glass tubing enables one to see whether the spinal canal has been reached with the first puncture. In the ordinary spinal puncture needle, one must withdraw the stylet entirely before one can see whether or not the spinal canal has been reached, thus ruming the risk of losing some fluid before the pressure can be measured. With the glass tubing on, one need only withdraw the stylet beyond the glass tubing, and if the spinal canal has been reached, the fluid 
withdrawn will be seen immediately through the glass. On the other hand, if no fluid makes its appearance, the stylet can be inserted again and another attempt made.

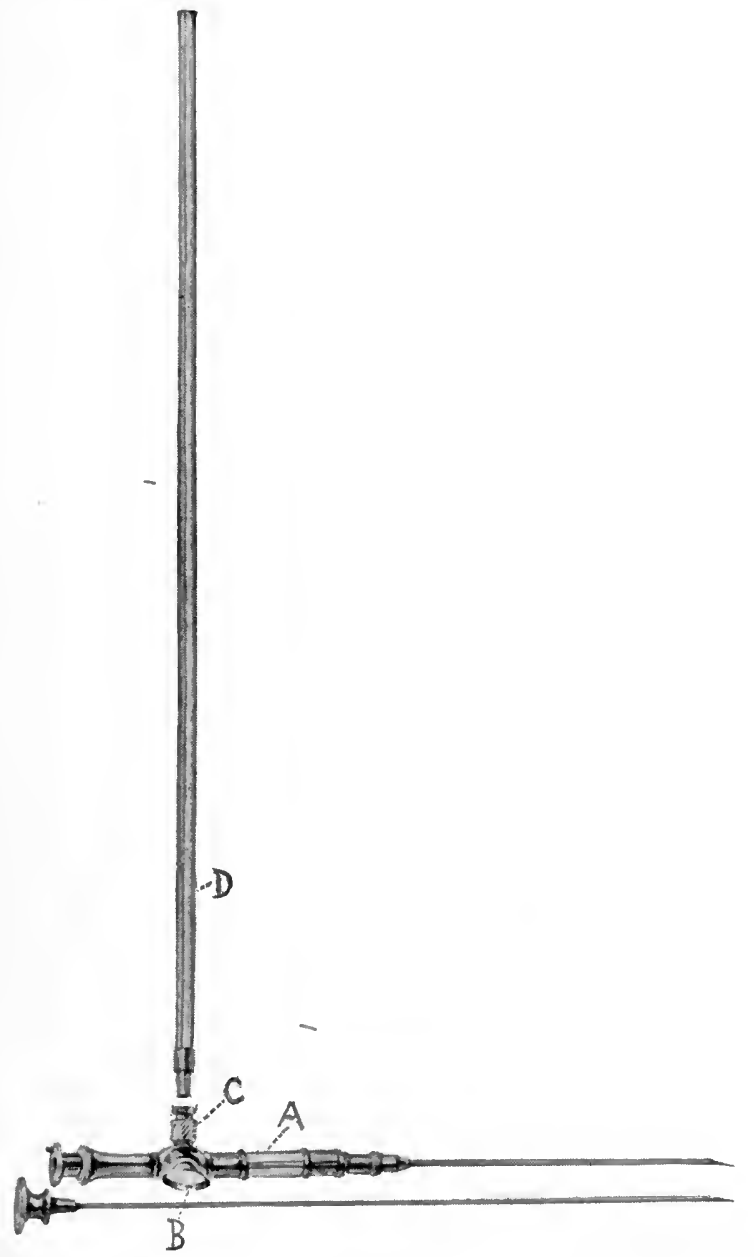

Jig. 14.-Author's spinal puncture needle and manometer; $A$, glass tubing in the needle; $B$, stopcock; $C$, upper projection of the needle into which the manomkter is in. troduced; $D$, glass inanometer.

The fear of breaking the glass on boiling the needle and sterilizing it is not a very strong objection. I liave boiled needles, repeatedly, without ever breaking the glass. 
The glass tubing may be slipped into the needle instead of being mounted, making possible the use of any form of spinal puncture needle. At the distal end of the glass tubing the needle has a three-way stopcock, the distal end of which is about three-fourths of an inch long. This length is required in order to allow space from the stopcock to the end of the needle so as not to lose any of the fluid as is the case when the valve of the stopcock is near the end of the needle. The stylet of the needle is long enough to reach from the distal to the proximal end of the needle.

The manometer consists of a long glass tube of one $\mathrm{mm}$. bore which is inserted into the projecting end of the needle. The glass tubing is $800 \mathrm{~mm}$. long as this was the highest pressure attained in any case, and for convenience sake, it is divided into two portions with a metal cap at the top of the first portion so that the other one can be screwed on. This makes it convenient to carry the manometer in any small instrument ease. Thick glass tubing is used for it so that it does not break easily in liandling. A metal tape is attached to the glass to measure the pressure. This, however, can be done away with and a ruler used instead, or have the glass tubing graduated.

The needle (with the piece of glass tubing at the end, the stopeock and its prolongation with the stylet inside) is introduced into the spinal canal. After a snap has been felt, so that one is reasonably certain the subdural canal is reached, the stylet should be removed to a point beyond the glass attachment. If fluid is seen in the glass tubing, the stopcock is turned at right angles so that the handle points upwards. The long glass tube is then attached and the stopcock turned so that the handle points opposite the manometer. The fluid will then rush into the tube. When the fluid has mounted to the highest point, the pressure is read off in millimeters of water. If no fluid is seen coming out when the stylet is removed bevond the glass tubing, the stylet should be reintroduced until the operator 
feels it is in the canal. It should then be removed beyond the glass and the measurement taken. The handle is now turned parallel to the needle and the fluid is collected in test tubes. The whole needle, including the glass attachment, stopcock, and prolongation is not any heavier than an ordinary medium-sized spinal puncture needle.

If no pressure apparatus is available, counting the drops and noting the force with which the fluid comes out from the needle will give a clew to the pressure, anything above ten drops per minute indicating an abnormal condition. I should like to remind the reader once more that the pressure must be taken at the very beginning, as after several cubic centimeters of fluid have been removed, the pressure lets up and determination then becomes practically valueless.

\section{Collection of the Fluid}

Some persons collect cerebrospinal fluid in graduated medicine glasses, so as to be able to measure the exact amount. This method of collection, however, is not advisable as it is hard to keep the fluid sterile in a wide glass, and it is also hard to observe the characteristic pellicle. I therefore, advise the collection of cerebrospinal fluid in test tubes.

The test tubes in which the fluid is to be collected should be sterile and chemically clean. It is best to use tubes of uniform size. The glass of the tube should not be too thick and its opening should be stoppered with a cotton plug, unless special tests requiring a slow escape of $\mathrm{CO}_{2}$ are to be made. For the sake of uniformity and because of the difference in the cell content of various portions of the cerebrospinal fluid, the following method has been found useful in cases where a quantity greater than 5 c.c. of fluid is withdrawn:

Several drops of the fluid are allowed to rum out of the needle to make sure that the fluid is free from blood. The 
entire amount is then collected into three tubes of uniform size. In the first test tube is run the first 2 c.c. of fluid. This amount is used for sereral different examinations: (1) cytologic examination; (2) direct smear for microorganisms if the fluid is turbid; (3) cultures; (4) 1 c.c. for the permanganate test. The contents of the first tube should be examined immediately. If it is not examined immediately, the test tube with its contents should be placed in the incubator.

In the second test tube, 3 to 5 c.c. of fluid is collected. If the pressure is not increased the contents of this test tube should be used for the globulin tests, Wassermann and Lange. If the pressure is increased the test tube should be put into a tube rack for the formation of a pellicle. Care should be taken that the mixture is not disturbed.

If there is a large amount of fluid present a third and fourth tube should be taken. Into the third tube should be rum from 5 to 8 c.c. of fluid. 'This fluid should be used for (1) the second portion of the permanganate test; (2) the Ross-Jones, Noguchi and Nonne, and the sulphosalicylic-mercuric chloride tests; (3) Lange test; (4) Wassermann test; (5) sugar content; (6) centrifugation, for the examination of organisms.

Into the fourth tube should be r'm all the rest of the fluid desired for collection.

In normal cases where the pressure is not increased only 5 to 10 c.c. of fluid should be withdrawn. In all cases of increased pressure a greater quantity of fluid should be removed. In delirium tremens, 10 c.c. usually suffices to quiet the patient. In meningitis, 15 to 40 c.c. may be withdrawn on account of the greatly increased amount of fluid in the canal. Even in the severe cases of meningitis, however, it is not advisable to remove more than 40 c.c. at one sitting on account of the danger of inducing shock. The quality of the pulse is a good guide as to the amount of fluid to remove. 
After the needle is withdrawn collodion should be put on the wound and the skin should be washed off if iodine has been applied before the puncture. The patient should be put to bed immediately after the puncture to prevent headache or dizziness.

\section{CRANIAL PUNCTURE}

When no cerebrospinal fluid can be drawn by way of lumbar puncture and it is found urgent to obtain some for diagnostic or therapentic purposes as is the case when meningitis is suspected or present, cerebrospinal fluid may still be obtained by cranial routes, either from the subarachnoid of the brain or from the ventricles. The amount of fluid obtainable from the subarachmoid space at best is small and the procedure is difficult. It is therefore always advisable to remove the fluid from the ventricles. The techuic employed for a ventricular puncture in infants when the anterior fontanelle is not yet closed, is as follows:

The patient is placed on the back with the head close to the edge of the table. The head around the region of the anterior fontanelle is shaved, and washed with alcohol and ether. Todine is applied to the surface. The needle to be used should be sterilized and all other necessary aseptic precautions should be taken. A short spinal puncture needle or an ordinary Luer needle should be used. The stylet should be left in the needle the same as in lumbar puncture, for if the stylet is removed brain tissue may clog the needle and prevent the flow of fluid. The needle should be introduced from $1 \frac{1}{1}$ to $1 \% 3$ inclies deep and the stylet renoved. The needle should be inserted into the anterior angle of the anterior fontanelle, in a somewhat oblique direction, a little to one side of the median line (Figs. 15 and 16) as piercing of the longitudinal simus will give blood in the fluid. After the desired amount of fluid is obtained, the needle is removed and collodion applied to the punctured surface. 
In adults, cranial puncture is most generally made for therapentic purposes, especially for the relief of intracranial pressure. It necessitates the use of a bore or a trephine to get through the skull. The method used is that of Kocher, consisting of a trephine opening $2.5 \mathrm{~cm}$. from the

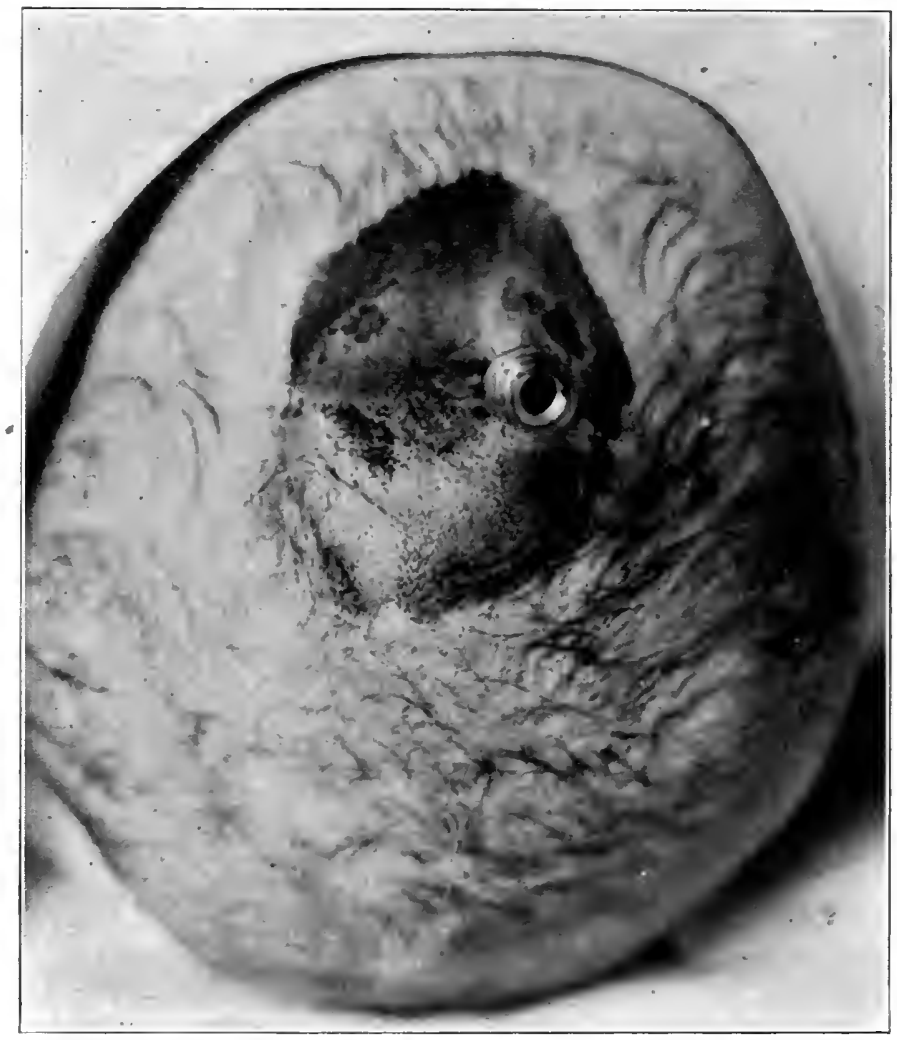

Fig. 15. - Photograph showing ventricular puncture in infant. Dark circular spot shows needle in position. (Front view.)

median line and $3 \mathrm{~cm}$. in front of the coronal or frontoparietal suture. The needle is then passed inward and slightly backward for a distance of 4015 cm. when the lateral ventricle is reached. The operation, in general, is a rather complicated one and calls for precision and careful 
surgical technic. It should therefore be used only when absolutely necessary. The rule should be to do a lumbar puncture whenever possible, but when fluid can neither be obtained nor introduced by way of lumbar puncture, then ventricular puncture should be made, especially in the case of infants.

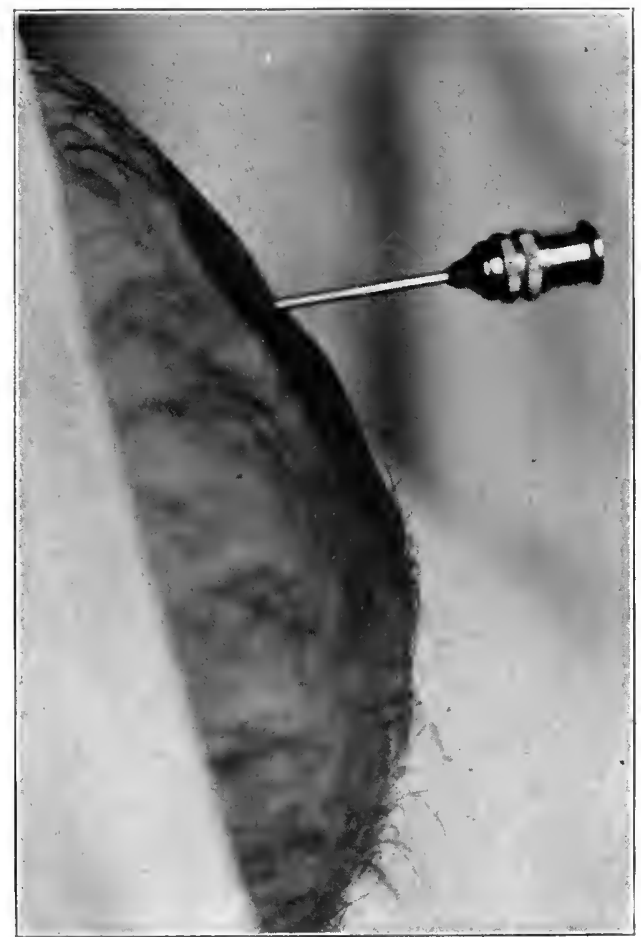

Fig. 16.-Photograph showing ventricular puncture in infant. (Side view.)

\section{Bibliography}

Brady: Lmmbar Puncture in Meningeal Hemorrlage of the New Born, Jour. Am. Med. Assn., 1918, lxxxi, 347 .

Curschman: Über die therapentische Bedentumg der Lumbalpunktion, Die Therapie der Gegenwart, 1912, lii, 242.

Funkhauser: Erfahrungen iiber Lumbalpunktion hei Geisteskranken, Korrespondenzbl. f. Sclhweiz. Irzte, 1907, xxvii, 33.

Gralam: Spinal Puncture in Diabetes Insipidus, Jour. Am. Med. Assn., 1917, lxix, 1498. 
Gumprecht: Gefahren bei der Lumbalpunktion plötzliche Todesfälle darnach., Deutsch. med. Wehnschr., 1900, xxri, 386.

Juvara: Topographie de la region lombaire en me de la ponetion dn canal rachidien, Semaine méd., 1907, No. 9.

Kroenig: Ưher Lumbalpunktion bei Eclampsie, Zentralbl. f. Gynäk., 1904, xxxix, 1153.

Kroenig und Gauss: Anatomisehe und physiologische Beobachtung ersten tausend Rückenmanksmäisthesien München. med. Wehnschr., 1907, liv, 1969.

Levinson: Measurements of the Spinal Puncture Needle, Jour. Lab. and Clin. Med., 1917, iii, 127.

Levinson: An Improved Spinal Puncture Needle and Pressure Apparatus, Jour. Am. Med. Assn., 1919, lxxii, 244.

MacRohert: The Canse of Lumbar Puncture Heidache, Jour. Am. Med. Assn., $1918, \operatorname{lxx}, 1350$.

Neisser and Pollak: Die Hirnpunktion und Punktion des Gehims und seiner Häute durch den intakten Schädel, Grenzgebiete der Mediz. und Chirurg., 190: , xiii, 807 .

Ossipow: ¿̈her die pathologisehe Veränderungen wolehe in dem Central Nerrensystem von Tieren durch die Limlalpunktion hervorgerufen werden, Deutsch. Ztschr. f. Nervenh., 1901, xix, 105.

Pfeiffer: Uber explorative Hirnpunktion zur Diagnose von Hirn, Arch. f. Psych. u. Nervenh., xlii, No. 2.

Quincke: Über Hydroeephalus, Verhandl. d. Cong. f. inn. Med., 1S91, x, 321.

Quincke: Die Technik der Lumbalpmnktion, 1902.

Quincke: Ueber Lumbalpunktion, Deutsch. Klin., 1906, vi.

Sehemensky: Lmmbalpunktion hei Typhis, Deutseh. Med. Wehnsehr., 1915, xli, 696.

Skoog: Cerebrospinal Fluid Pressure, Jour. Am. Med. Assn., 1917, 1xix, 1064. 


\section{CHAPTER IV}

\section{PROPER'TIES OF NORNAL CEREBROSPINAL FLUID}

The term "normal" as applied in the literature to cerebrospinal fluid is often misleading. The mere fact that cerebrospinal fhuid has been removed from a living person is indicative of the presence of some abnormality of the nervous system that prompted the puncture. Often the bacteriologic and qualitative chemical tests on a given specimen of fluid are negative, yet quantitative chemical analysis will show an alteration in the chenical or physical chemistry of the fluid. Furthermore, fluid removed postmortem can hardly be considered normal, for it has usually undergone marked chemical and physicochemical changes before examination. For instance, fluid removed postmortem las been shown by Myers to contain three and one-half times as much potassium oxide as fluid removed during life. I also found a marked difference between fluid removed during life and after death. In the former case the fluid was slightly alkaline and in the latter, distinctly acid. "Normal" as applied to cerebrospinal fluid should, therefore, be considered merely as a relative term; the term "nonmeningitic" perhaps would be still more accurate to designate the condition of the fluid where there may be some pathologic condition of the nervous system, such as brain tumor, hydrocephalus or the like, but no involvement of the meninges.

In the discussion following in this chapter I shall state so far as possible whether the cerebrospinal fluid under diseussion was withdrawn during life or postmortem, and whether it was obtained by lumbar or by ventricular puncture. I shall also endeavor to indicate the diagnosis of the respective cases so that the reader may be able to form an opinion regarding the type of the fluid in question. 


\section{PHYSICAL PROPERTIES}

\section{Amount}

The amount of fluid normally present in the ventricles and in the subarachnoid space has been variously stated. Contugno found between 125 and 156 c.c. in both; Magendie found between 62 and 372 c.c.; Luschka found only 25 c.c. According to Magendie, the normal amount of cerebrospinal fluid in a medium-sized man is 62 e.c. Of this amount, Magendie says, the rentricles contain from 20 to 30 c.c., and the subarachnoid space of the cord the greatest part of the remainder. It may be interesting to note that although there is from 60 to 150 c.c. of cerebrospinal fluid present in the subarachnoid space and the ventricles, it is generally inadvisable and often impossible to remove more than 10 c.c. of fluid from a patient at one sitting.

\section{Color}

Normal cerebrospinal fluid is clear and colorless, provided no blood has been removed with it during the puncture. The fluid does not change color upon standing if it is corked with a cotton plug, unless, of course, it has become contaminated by bacteria or moulds, in, which case the fluid becomes turbid.

\section{Lack of Sediment}

Normal cerebrospinal fluid shows no pellicle or sediment of any kind. This is because of the fact that the cell content, as well as the protein content, is very small, and fibrin is either entirely absent or present only in very small traces. The lack of sediment is helpful in differentiating normal or nonmeningitic fluid from fluid in cases of meningitis, especially tuberculous, in which the diagnosis is difficult because of the clearness of the fluid. 


\section{Pressure}

Observations on the pressure of normal cerebrospinal fluid have given various results in the hands of different workers. Magendie found that the pressure of the cerebrospinal fluid is positive. Falkenheim and Naunyn claim that it is necessary for the maintenance of the blood circulation of the brain that the cerebrospinal fluid remain at a certain pressure and they estimate the pressure under normal conditions to vary between 50 and $200 \mathrm{~mm}$. of water (4 to $16 \mathrm{~mm}$. $\mathrm{Hg}$ ) for a child one month to one year of age with a correspondingly higher pressure for an adult. Quincke gives 40 to $60 \mathrm{~mm}$. of water as the normal pressure for children, and 150 for adults; Adamkiewicz gives 80 to $100 \mathrm{~mm}$. of water, and Sicard gives 200 as the normal pressure. Many factors are responsible for these discrepancies, the most important of them being the type of the pressure apparatus, the insertion of the needle, the age of the patient, the position of the patient during the puncture, the position of the liead, the respiratory movements, and such external factors as coughing, sneezing and crying.

(a) Different pressure apparatus give different pressure values. In some forms of apparatus fluid is lost and therefore too small values are obtained. (Cf. Chapter III.) The position of the needle is also responsible for variation in pressure. A deeper insertion of the needle into the canal gives a ligher pressure than a slight insertion, and vice versa.

(b) Age also plays a part in the pressure of the fluid. Quincke found pressure in children to be less than that in adults. He gives 40 to $60 \mathrm{~mm}$. water as the pressure in children, and $150 \mathrm{~mm}$. water as the pressure in adults. I also found the pressure to be lower in children than in adults. My figures showed a pressure variation of from 45 to $90 \mathrm{~mm}$. water in children in a quiet recumbent posture and 130 to $150 \mathrm{~mm}$. water in adults. 
(c) The position of the patient during puncture has a marked influence on the pressure, the pressure in the sitting position being much higher than in the recumbent position. Kroenig found the pressure in the lying posture to be $120 \mathrm{~mm}$. of water and in the sitting posture $410 \mathrm{~mm}$. of water. E. Cotton and M. C. Salz found the normal pressure in the recumbent position to be 200 to $230 \mathrm{~mm}$. of water and in the sitting position to be 400 to $420 \mathrm{~mm}$. water. I found the normal pressure in the recumbent position in children under ten to vary between 45 and $90 \mathrm{~mm}$. of water and in the sitting position to rary between 150 and $230 \mathrm{~mm}$. of water. In adults, in recumbent position the pressure varied between 130 and 150 and in the sitting position between 200 and 250.

(d) Flexion of the head on the chest lessens the pressure and extension of the head raises the pressure, the difference between the two varying from 150 to $230 \mathrm{~mm}$. of water.

(e) Magendie commented on the effect of the respiratory movements on the pressure of the fluid. He observed that the cerebrospinal fluid showed movements corresponding to the respiration, the pressure falling during inspiration and rising during expiration. This observation has been confirmed by many workers. I have observed it frequently. The variation between inspiration and expiration, however, is small, the difference averaging from 10 to $15 \mathrm{~mm}$. of water.

(f) The relation between the pressure of the cerebrospinal fluid and the pulse beat was pointed out by Falkenheim and Naunyn. This is noticeable, however, only when the pressure is high, above $300 \mathrm{~mm}$. of water.

(g) Coughing, crying, sneezing or any other strain may increase the pressure from 50 to $100 \mathrm{~mm}$. of water.

Summarizing, it may be said that the normal pressure of the cerebrospinal fluid is influenced by many factors. As a general rule, however, the pressure varies from 45 to $90 \mathrm{~mm}$. in children, and from 130 to $150 \mathrm{~mm}$. in adults. 
TABI_E IV

Cerebrospinal Fluid Pressure in Normal Individuals Expressed in Milimeteis OF WATER

\begin{tabular}{lcccc}
\hline \multirow{2}{*}{ Author } & \multicolumn{2}{c}{ ADUIT } & \multicolumn{2}{c}{ CHILI } \\
& LYING & SITTING & LYING & SITTING \\
\hline Quincke & 150 & & $40-60$ & \\
Adamkiewicz & $80-100$ & & & \\
Kroenig & $125-150$ & 410 & & \\
Cotton and Salz & $200-300$ & $400-420$ & & \\
Boveri & $170-200$ & & & \\
Levinson & $130-150$ & $200-250$ & $45-90$ & $150-230$ \\
\hline
\end{tabular}

These figures are for the recumbent position. They are very much higher for the sitting position. The withdrawal of several cubic centimeters of cerehrospinal fluid lessens the pressure temporarily, but in a very short time it returns to normal. So it frequently lappens that when two punctures are made in one day, the pressure is found to be the same in both cases.

\section{Specific Gravity}

The specific gravity of normal cerebrospinal fluid varies between 1.001 and 1.008. Hoppe found the gravity in a case of spina bifida to be 1.001 and in one case of hydroceplatus to be 1.005. Talliburton found the gravity of normal fluid to be 1.007 to 1.008 , and Kafka found it to vary between 1.002 and 1.008. Zalarek gives the specific gravity of normal cerehrospinal fluid as 1.0078, Polámyi as 1.012 (15 degrees); 1.007 and 1.005. Nestrezat found it to be 1.0076, and Nawratski found it to be 1.0073 to 1.008 . In a series of nommeningitic cerebrospinal fhids examined by the pyknometer I found the specific enravity to vary between 1.0064 and 1.0070 .

\section{CHEMICAL COMPOSITION}

In spite of the large annount of work on the chemical composition of the cerebrospinal fluid, there are many funda- 
mental questions pertaining to the chemistry of this fluid that have not yet been answered. The reason that our information regarding the chemistry of cerebrospinal fluid is not as definite and as accurate as it might be, is that the anount of fluid one is obliged to work with under normal conditions is usually so small (5 to 10 c.c.) that it hardly permits any quantitative separations.

It is but recently that microchemical methods have been derised for body fluids, and even now, with improved methods, it is hardly possible to make an entire quantitative analysis on one normal specimen of cerebrospinal fluid. 'This scarcity of fluid necessitates working' on one chemical substance at the time or the use of a mixture of fluids for the determination of the various chemical constituents, a procedure adopted by Mestrezat. One can readily see that data gathered in this way can not be very accurate, especially since the chemical character of the fluid is affected by such factors as the condition of the patient, and the age of the fluid. It is surprising to note, however, that with all of the drawbacks some of the chemical determinations of the very early investigators still hold good, particularly the determinations of the organic matter, and of the amount of the total solids and chlorides.

I shall present here data obtained from the literature, following the experiments so far as possible in chronologic order to show the evolution of chemical methods as applied to cerebrospinal fluid. I shall give a complete table at the end of the discussion showing the results of the work by various authors on the chemistry of the cerebrospinal fluid.

One of the earliest determinations of the chemical composition of cerebrospinal fluid was that of Lassaigne who examined the cerebrospinal fluid of a horse after death. The fluid was obtained for the chemist by Magendie. The analysis gave the following composition per 100 parts: 


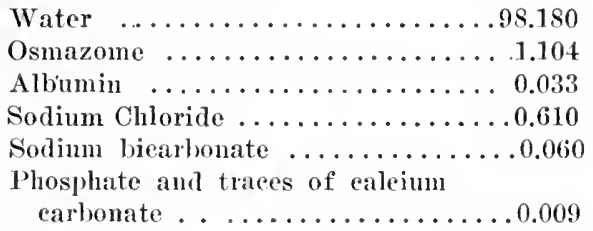

Lassaigne conld not find any soluble phosphates in the liquor.

The same author examined the cerebrospinal fluid of an old woman and found the following per 100 parts:

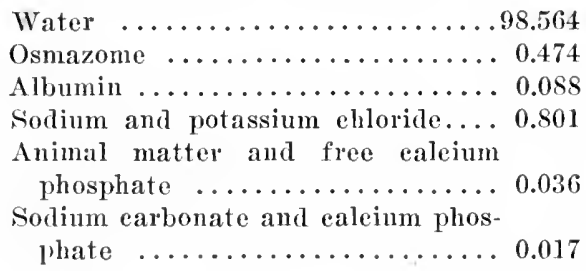

Among the early workers in this field was Hoppe. He made a chenical analysis in two cases of spina bifida and three cases of internal hydrocephalus. In one case of spina bifida, he removed 22 to 35 c.c. of cerebrospinal fluid at a sitting. (The author unfortmately does not give the method he employed in the removal of the fluid.) He found the fluid very alkaline. (Here again the author does not say what indicator he used, or how long after removal of the fluid from the body, he examined it). On heating, the fluid became slightly turbid, but on addition of acetic acid, floceuli appeared. The fluid rerlnced copper oxide and gave the following quantitative results in grams per 1000:

\begin{tabular}{|c|c|c|c|}
\hline & FIRST & SECOND & THIRD \\
\hline & PUNCTURE & PUNCTURE & PUNCTURE \\
\hline Albumin & 1.62 & 2.64 & 2.46 \\
\hline Water extractive & 0.70 & 0.35 & 0.42 \\
\hline Alcohol extractive & 9.57 & $\begin{array}{l}2.48 \\
7.52\end{array}$ & 2.23 \\
\hline Insoluble salt & 0.25 & 0.15 & 0.28 \\
\hline \multicolumn{4}{|l|}{ Giving- } \\
\hline 1)ry substance & 12.51 & 13.12 & 13.28 \\
\hline Water & 987.49 & 986.88 & 986.72 \\
\hline
\end{tabular}


From the second case of spina bifida the author obtained 500 c.c. of cerebrospinal fluid, in the first puncture, and 435 c.c. in the second puncture. The reaction of the fluid in this case was also stated to be alkaline. On boiling, very little if any turbidity occurred. On the addition of acetic acid slight flocculeney occurred. Quantitative analysis showed the following in grams per 1000:

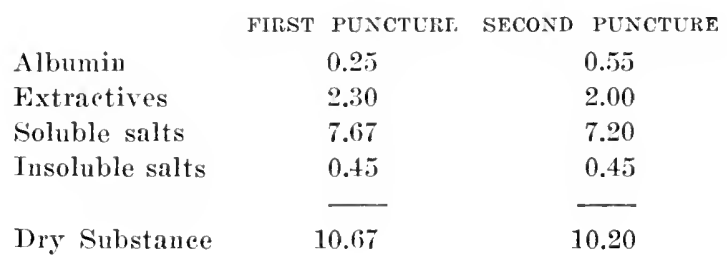

One case of hydrocephalus in a five-month-old girl gave Hoppe the following in grams per 1000: albumin 0.70, extractives, 1.57 , soluble salts 7.67 , insoluble salts 0.53 , giving dry substance 10.47 .

Another case of hydrocephalus gave Hoppe the following in grams per 1000: albunin 11.79, alcohol extractives 0.84 , water extract 0.48 , soluble salts 7.54 , insoluble salts 0.35 , and dry matter 20.99. It is evident, lowever, from the author's description of the fluid of the last ease which he says was of a greenish yellow color and showed a large sediment, absence of sugar and numerous cells, that the case was one of meningitis.

Halliburton also was one of the first to study the chemical composition of cerebrospinal fluid. He found no coagulation of the fluid at $56^{\circ} \mathrm{C}$. and no fibrin on the addition of sermo or fibrin ferment. He found further that practically all the protein present in the cerebrospinal fluid was precipitated by saturation with magnesium sulphate. The analysis of cerebrospinal fluid in a number of cases gave Halliburton the following results in parts per 1000: 
CASE 1. FEMALE-AGE 19

$\left.\begin{array}{l}\text { Water } \\ \text { Solids } \\ \text { Proteins } \\ \text { Extractives } \\ \quad \text { and } \\ \text { Salts }\end{array}\right\}$

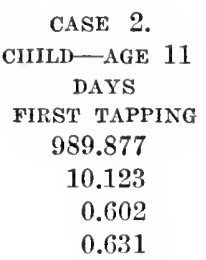

7.890

CASE 3.
CHID-AGE 13
WEEKS
FOURTH TAPPING
991.658
8.342
0.199
3.028

5.115

It is interesting to note in this connection the part taken by Halliburton in the discussion concerning the nature of the redueing substance in the cerebrospinal fluid. As early as 1852, Deschambs and Bussy described the presence of a copper-reducing substance in eerebrospinal fluid, a finding eorroborated by numerous other workers. However, the character of this substance has been made the subject of a great deal of discussion. Quineke, Comba, Friedenthal, Panzer and others considered it to be a dextrose. Halliburton however, supported by Mathien, Gauthies and others expressed the view that the reducing substance was pyroeatechin. Langstein thought that a portion of the reducing substance was galactose and Dubos believed that it was a xanthine body. Recent investigations have settled this eontroversy, the phenylhydrazin, the fermentation test, and the polariscope definitely proving its identity as a dextrose. Even Halliburton now admits that this redueing substanee is a dextrose.

The early investigations on the ehemistry of cerebrospinal fluid were made on eases of liydrocephalus or spina bifida. Of recent years some work has been done on the chemistry of eerebrospinal fluid of eomparatively normal persons. The work of Mestrezat, of Leopold and Bernhard deserves special attention in this connection. There are many additional facts on the ehemical constituents of the cerebrospinal fluid scattered throughout the literature, some of which are included in the table at the end of the chapter. 
Mestrezat, in a series of analyses, found the following chemical composition of cerebrospinal fluid, expressed in grams per 1000 parts: fixed matter 10.65 to 11.00 , with an average of 10.93 ; organic matter 1.75 to 2.65 with an average of 2.13 ; mineral matter 8.50 to 9.00 , with an average of 8.80 ; protein 0.13 to 0.30 with an average of 0.18 . He found no fibrinogen, no albumose or peptones, or nucleoprotein and mucin. He also noted the absence of cholin, and cholesterol (or only a very small trace of cholesterol). Amino acids were present on the average in the amount of 0.010 , urea on the average of 0.06 , varying between the extremes of 0.03 and 0.10 . The presence of ammonia was questionable, total nitrogen was found on the average of 0.197 , with the extremes of 0.196 to 0.198 ; sugar (reducing matter and glucose) on the average of 0.53 , with the extremes 0.48 to 0.58 . Total organic acids were present on an average of 0.30 . There was, however, no acetone found; chlorides on the average of 7.32 , with the extremes of 7.25 to 7.40 ; total phosphorus on the average of 0.030 in terms of $\mathrm{P}_{2} \mathrm{O}_{5}$ with the extremes of 0.029 to 0.031 ; inorganic phosphorus on the average of 0.012 in terms of $\mathrm{P}_{2} \mathrm{O}_{5}$; organic phosphorus on the average of $0.018 \mathrm{in}$ terms of $\mathrm{P}_{2} \mathrm{O}_{5}$; total sulphur on the average of 0.056 with the extremes of 0.028 to 0.071 ; inorganic sulphur on the average of 0.010 in terms of $\mathrm{SO}_{3}$; organic sulphur on the average of 0.046 in terms of $\mathrm{SO}_{3}$; nitrates on the average of 0.009 ; no nitrites; sodium 4.346 as $\mathrm{Na}_{2} \mathrm{O}$; potassium 0.251 as $\mathrm{K}_{2} \mathrm{O}$; ratio of $\mathrm{K}_{2} \mathrm{O} / \mathrm{Na}_{2} \mathrm{O} 1 / 17.3$; calcium 0.095 as $\mathrm{CaO}$; magnesium 0.050 as $\mathrm{MgO}$.

Leopold and Bernlıard determined the nonprotein nitrogen of normal cerebrospinal fluid. They found that the nomprotein nitrogen varied between 17 and $26 \mathrm{mg}$. per 100 c.e. of cerebrospinal fluid the average amount being $21 \mathrm{mg}$. The urea varied between $\tau$ and $13.5 \mathrm{mg}$. per 100 e.c. of fluid, the average amount being $9.9 \mathrm{mg}$. The creatinine varied between 0.7 and $1.5 \mathrm{mg}$. per 100 c.c. of fluid, the arerage 
amount being $0.9 \mathrm{mg}$. The sugar content varied between 0.07 and 0.1 per cent, the average content being 0.07 per cent.

My own work on the chemistry of cerebrospinal fluid is concerned mostly with the constituents that have or were expected to have a direct bearing on the differential diagnosis and pathogenesis of various diseases, including the protein content, the organic index, the sugar content, lactic acid, and urea, among the organic constituents, and the chlorides, the phosphates and $\mathrm{CO}_{2}$ among the inorganic constituents. The organic index was determined by the permanganate method of Meyerhofer, taking the amount of permanganate required to oxidize the organic substance in the cerebrospinal fluid as an index (the method will be described in detail in Chapter VI). The protein was determined by precipitating the cerebrospinal fluid with equal amounts of 5 per cent trichloracetic acid, with a pinch of kaolin, filtering off the inorganic constituents and determining the nitrogen in the sediment by the K.jeldahl method and multiplying by the factor $\mathrm{N} \times 6.25$. The sugar was determined by the Kowarsky method and also by the Lewis and Benedict method. Occasionally, the Epstein microchemical method was nsed. Urea was determined by the Folin method, acetone was determined qualitatively by the sodium nitroprusside method. Lactic acid by Uffelmans reagent, noting the drops of cerebrospinal fluid required to change the reagent to a camary yellow. The chlorides were determined by the Seelman method, the phosphates by the uranium acetate method and the $\mathrm{CO}_{2}$ by the Van Slyke method for the determination of alkali reserve and then calculating out the $\mathrm{CO}_{2}$ from the results obtained, or the alkali reserve was obtained by methyl red tituation. I should like to emphasize here that the fluid has been nonmeningitic, but nevertheless not always absolutely normal. 'Tables V, VT, and VII show some of the average findings in nonmeningitic fluids. 
Table V

The Permanganate Index in Nonmeningitic Fluid

\begin{tabular}{clccc}
\hline \hline \multirow{2}{*}{ No. } & DIAGNosis & \multicolumn{3}{c}{ PERMANGANATE } \\
& & INDEX \\
& FIRST & TUBE & SUBSEQUENT & TUBES \\
\hline 1 & Typhoid & 1.8 & 1.6 & 1.7 \\
2 & Pneumonia & 1.3 & 1.3 & \\
3 & Pneumonia & 1.4 & 1.2 & 1.0 \\
4 & Tetany & 1.3 & 1.2 & \\
5 & Epilepsy & 1.3 & 1.1 & \\
6 & Grippe & 1.5 & 1.4 & \\
\hline
\end{tabular}

TABLE VI

Sugar Content in Nonmeningitic and Nonluetic Cases

\begin{tabular}{|c|c|c|c|}
\hline No. & DIAGNOSIS & $\begin{array}{l}\text { SUGAR } \\
\text { CONTENT }\end{array}$ & $\begin{array}{l}\text { OTHER } \\
\text { TESTS }\end{array}$ \\
\hline 1 & $\begin{array}{l}\text { Alimentary } \\
\text { Intoxication }\end{array}$ & 0.116 & $\begin{array}{l}\text { Chemical and } \\
\text { baeteriologic } \\
\text { tests negative }\end{array}$ \\
\hline 2 & $\begin{array}{l}\text { Pneumonia with } \\
\text { meningism }\end{array}$ & 0.108 & $\begin{array}{l}\text { All tests } \\
\text { negative }\end{array}$ \\
\hline 3 & Insanity & 0.108 & Negative \\
\hline 4 & Uremia & 0.067 & Negative \\
\hline 5 & Insanity & 0.058 & Negative \\
\hline 6 & Insanity & 0.048 & Negative \\
\hline 7 & Otitis Media & 0.032 & Negative \\
\hline 8 & Erysipelas & 0.144 & Negative \\
\hline 9 & Renal Insufficiency & 0.048 & Negative \\
\hline 10 & $\begin{array}{l}\text { Pneumonia and } \\
\text { meningism }\end{array}$ & 0.032 & Negative \\
\hline 11 & Pneumonia & 0.088 & Negative \\
\hline 12 & $\begin{array}{l}\text { Brain tumor } \\
\text { also right }\end{array}$ & & \\
\hline 13 & $\begin{array}{l}\text { ovarian eyst } \\
\text { Cerebral spastie }\end{array}$ & 0.116 & Negative \\
\hline & paralysis & 0.06 & Negative \\
\hline 14 & Hydroeephalus & 0.104 & Negative \\
\hline 15 & Insanity & 0.118 & Negative \\
\hline 16 & Hematogenous Jaundice & 0.12 & Negative \\
\hline 17 & Epilepsy-had menin- & & \\
\hline & gitis one year previously & 0.068 & Negative \\
\hline 18 & Encephalitis, & 0.048 & Negative \\
\hline 19 & $\begin{array}{l}\text { Cerebellar tumor, re. } \\
\text { peated convulsions }\end{array}$ & 0.072 & Negative \\
\hline 20 & Brain tumor & 0.068 & Negative \\
\hline 21 & Multiple selerosis & 0.148 & Negative \\
\hline 22 & $\begin{array}{l}\text { Localized encephalitis } \\
\text { recovered. }\end{array}$ & 0.140 & $\begin{array}{l}\text { Negative } \\
\quad(\text { Cont'd p. 87) }\end{array}$ \\
\hline
\end{tabular}


PROPERTIES OF NORMAL CEREBROSPINAL FLUID

TABLe VI-Cont'd

Sugar Content in Nonmeningitic and Nonluetic Cases

\begin{tabular}{llll}
\hline \hline No. & DIAGNosis & $\begin{array}{l}\text { SUGAR } \\
\text { CONTENT }\end{array}$ & $\begin{array}{l}\text { OTHER } \\
\text { TESTS }\end{array}$ \\
\hline 23 & Acidosis (?) & 0.104 & Negative \\
2.4 & Normal & 0.086 & Negative \\
2.5 & Normal & 0.09 & Negative \\
26 & Normal & 0.106 & Negative \\
27 & Normal & 0.064 & Negative \\
28 & Normal & 0.088 & Negative \\
& & Blood sugar-0.088 & Negative \\
29 & Normal & 0.108 & Negative \\
30 & Normal & 0.064 & Negative \\
31 & Normal & 0.07 & \\
\hline
\end{tabular}

TABLE VII

Cimlorides in Nonmeningitic Fluid

\begin{tabular}{clc}
\hline \hline NO. & Diagnosis & $\begin{array}{c}\text { CHLORIDES } \\
\text { (IN GMS. PER 100 c.c.) }\end{array}$ \\
\hline $\mathbf{1}$ & Psychosis & 0.74 \\
2 & Alcoholic psychosis & 0.72 \\
3 & Aleoholic psychosis & 0.60 \\
4 & Neningism & 0.72 \\
5 & Preumonia & 0.60 \\
6 & Psychosis & 0.68 \\
7 & Psychosis & 0.70 \\
8 & Tertiary lues & 0.75 \\
9 & Chorea & 0.70 \\
\hline
\end{tabular}

TABLE VIII

Urea in Nonmeningitic Fluid

\begin{tabular}{c|c|c}
\hline No. & DIAGNOSIS & UREA IN GM. PER 100 c.C. \\
\cline { 3 - 3 } 2 & Psychosis & 0.032 \\
3 & Meningism & 0.090 \\
4 & Psychosis & 0.042 \\
5 & Psychosis & 0.064 \\
6 & Meningism & 0.070 \\
& Psychosis & 0.043
\end{tabular}

The amount of $\mathrm{CO}_{2}$ in the cerebrospinal fluid varied in my cases with the time the fluid has been standing after removal from the body. The longer it stands before exami- 
nation the less $\mathrm{CO}_{2}$ it contains. In fluid examined immediately after withdrawal from the body, the $\mathrm{CO}_{2}$ varies between $0.110 \mathrm{gm}$. and $0.124 \mathrm{gm}$. per 100 c.c. In fluid examined five to six hours after it has been remored from the body, the $\mathrm{CO}_{2}$ varies between 0.098 gm. and $0.106 \mathrm{gm}$. per 100 c.c. Table IX shows some of the amount of $\mathrm{CO}_{2}$ obtained in rolumes per cent.

\section{Table IX}

Total Carbonate of Nonmenisgitic Cerebrospinal Fluid and Its RELATION TO THE H-ION CONCENTRATION

\begin{tabular}{|c|c|c|c|}
\hline so. & DIAGNosis & PHI & $\begin{array}{c}\text { TOTAL CARBONATE IN } \\
\text { VOLEAIE PËR CENT }\end{array}$ \\
\hline 1 & Dementia Precox & 7.4 & 58.75 \\
\hline$\ddot{2}$ & Psychosis & $7 . t$ & 55.72 \\
\hline ، & ، & 7.7 & 51.52 \\
\hline 3 & Cerebrospinal Lues & 7.5 & 55.72 \\
\hline ، & 66 & 7.6 & 54.83 \\
\hline 4 & Psychosiz & 7.4 & 57.54 \\
\hline ‘ & ، & S.1 & 50.47 \\
\hline 5 & Tabes & 7.4 & $63.6 \mathrm{~s}$ \\
\hline ، & c6 & 8.1 & 54.08 \\
\hline 6 & Cliorea & $7.5-7.6$ & 63.0 \\
\hline ، & 6 & 8.1 & 52.48 \\
\hline 7 & Encephalitis & 7.7 & 51.3 \\
\hline
\end{tabular}

Lactic acid was present in traces. It took, as a rule, 15 to 20 drops of cerebrospinal fluid to change the color of 5 c.c. of Uffelman's reagent to canary yellow. Acetone was negative in all nommeningitic fluid, so was also ammonia.

\section{Crystallization}

I evaporated a number of specimens of cerebrospinal fluid, after precipitating and filtering off the protein. The resultant crystals (Figs. 17 and 18) resemble those of sodium chloride (Fig. 19) in most respects.

Then we now examine cerebrospinal fluid for the constituents it contains we find the following amounts: water, 98.60 to $99.12 \pm$ per cent; solids, 0.876 to 1.631 per cent. Of the solids, 0.175 to 0.265 per cent is organic matter and the 
rest mineral matter. The organic matter is made up principally of protein, sugar and urea. Protein is present in amounts varying between 0.013 and 0.07 ; sugar is present in amounts varying between 0.032 and 0.144 per cent.

The bulk of the inorganic matter consists of chlorides and
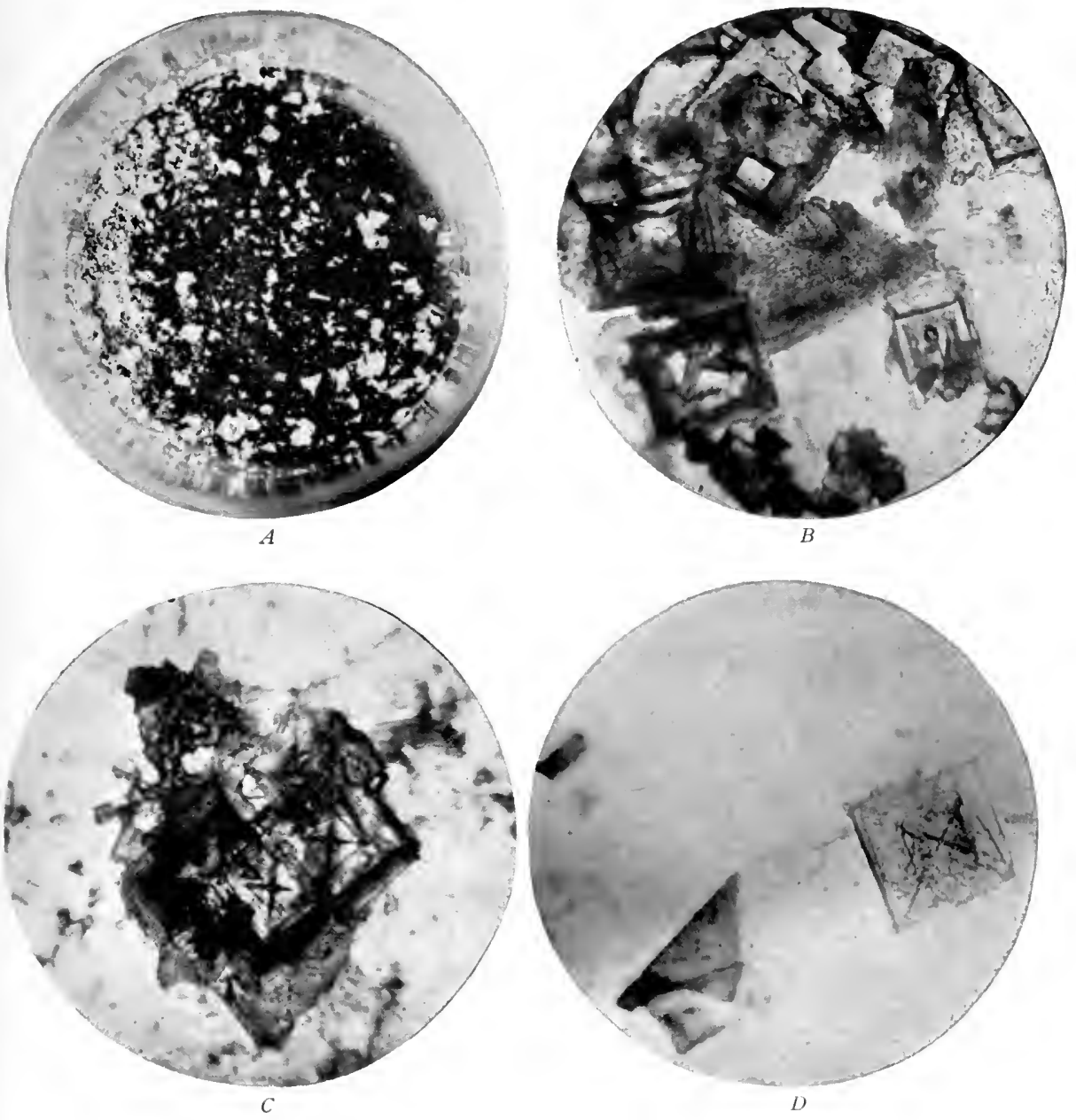

Fig. 17. - Crystallization of nonmeningitic cerebrospinal fluid.

A. Crystals obtained after the protein has been removed from the fluid by precipitation and the filtrate, evaporated on steam hath. (Natural size.)

B. Same fluid showing the erystals. (Magnified 24 times.)

C. Clump of crystals of same fluid. (Magnified 45 times,)

D. Single crystal. (Magnified 45 times.) 


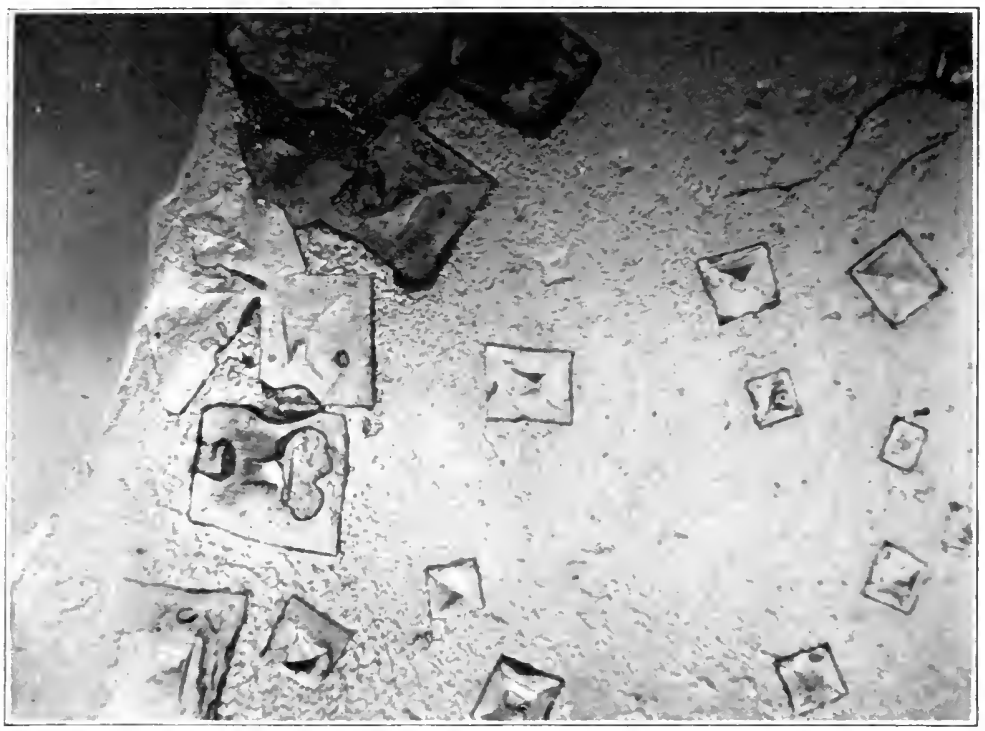

Fig. 18.-Crystals of evanorated nommeningite cerebrospinal fluid. (Magnitied 24 diameters.)

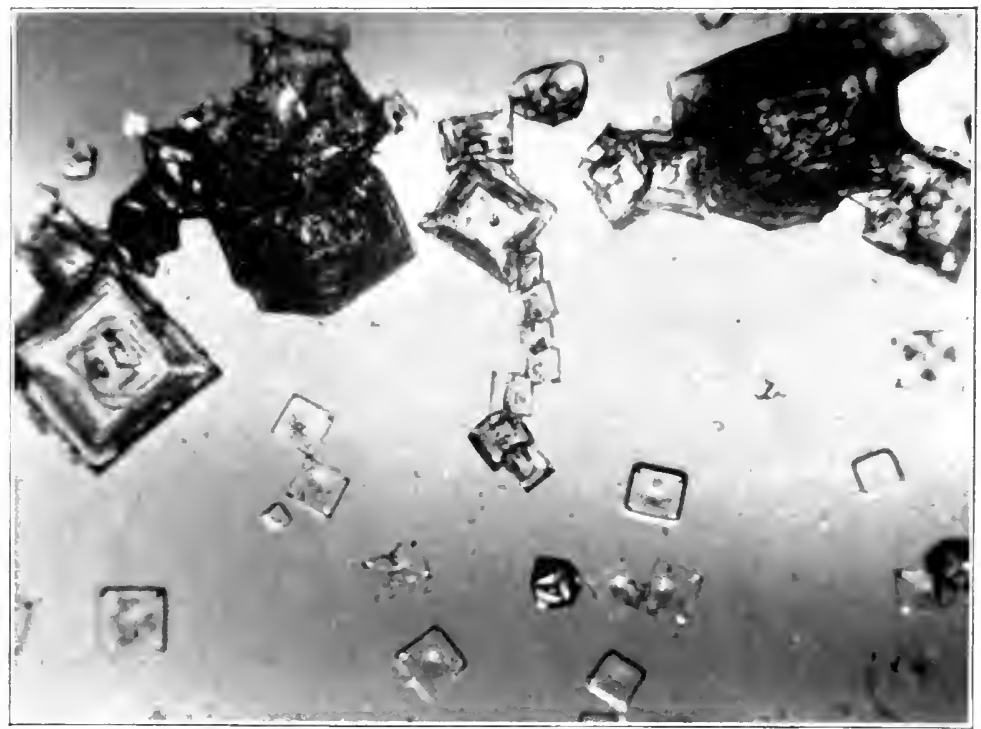

Fig. 19.-Crystals of sodium chloride in a 1 per cent solution of dextrose. (Magnified 24 diameters.) 


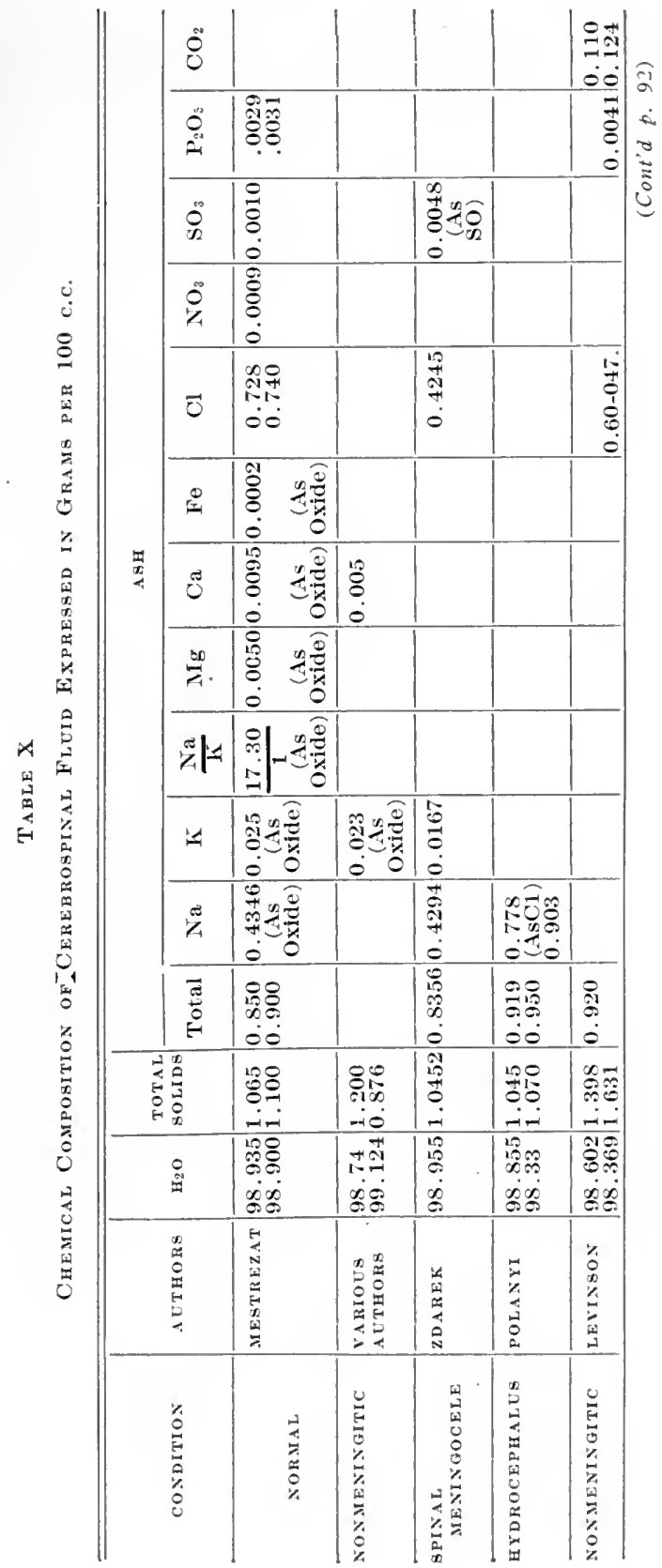




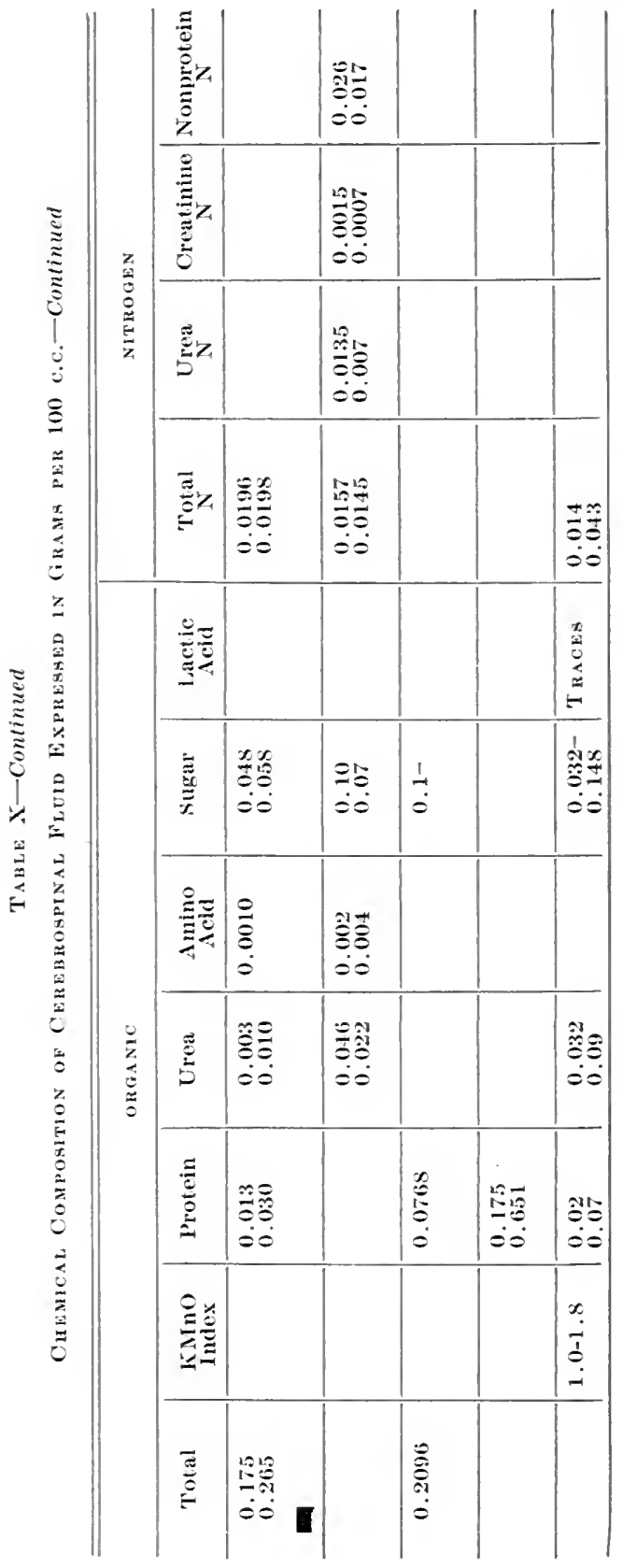


bicarbonates, the chlorides being present in amounts varying between 0.60 and 0.74 per cent.

Both of these constituents are present in much greater quantities than potassium, calcium or magnesium.

It is interesting to compare the chemical composition of the cerebrospinal fluid with that of other body fluids, notably blood, lymph, and aqueous humor. In comparing the

TABLE XI

Chemical, Composition of Cerebrospinal Fluid Compared witil that of BLOOD

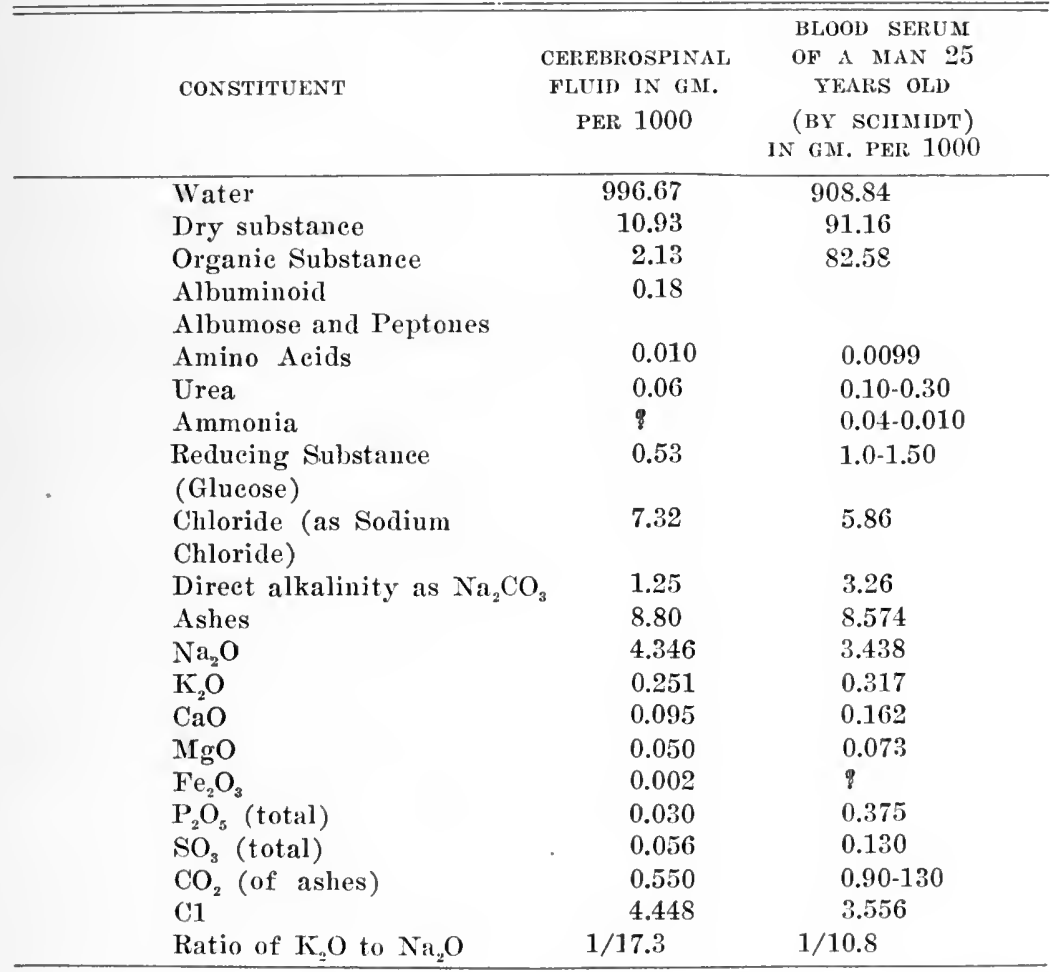

chemical composition of the cerebrospinal fluid with that of the blood we find that they both contain practically the same constituents, and that some of the constituents are present in the same amounts in both. This is particularly true of sugar and urea. I often found sugar to be present in the 
same amounts in both the fluid and in the blood. Cullen and Ellis found a difference of less than $2 \mathrm{mg}$. per 1000 c.c. in the amounts of urea in the fluid and the blood, in 63 per cent of their determinations. The urea content of the fluid varied from 22 to $46 \mathrm{mg}$. and that of the blood serum between 20 to $42 \mathrm{mg}$.

The other chemical constitnents, on the contrary, are present in much smaller proportions in the fluid than in the blood. The protein in the fluid varies between 0.013 and 0.07 whereas that in the blood plasma varies between 6.95 and 7.76 per cent. The calcium content of the fluid, according to Halverson and Bergeim, is only one-half that of the blood, the calcium in the fluid being $0.00 \mathrm{~s} \mathrm{gm}$. per 100 c.c., while that in the blood plasma or serum is 0.01 per 100 c.e. Table XI of Mestrezat shows the chemical constituents of the cerebrospinal fluid and the blood.

\section{PHYSICOCHEMICAL PROPERTIES OF NORMAL CEREBROSPINAL FLUID}

There is no line of scientific investigation where so many factors enter into the results obtained as in physicochemical determinations. Temperature, barometric pressure and especially the time the fluid has been standing before it is examined count a great deal. So it comes that while the chemical data found in the literature of several years ago are in the main confirmed by newer investigations, some of the older physicochemical data are found incorrect when newer methods are used, and when the various factors influencing physicochemical findings are taken into consideration. Especially is this true with regard to the reaction of the cerebrospinal fluid and the alkali reserve.

\section{Specific Gravity}

The specific gravity of normal cerebrospinal fluid to which $I$ have already referred in the discussion of the physical properties of normal cerebrospinal fluid, belongs also 
in a discussion on physicochemical properties of the fluid. since specific gravity forms the basis of many physicochemical constants. The specific gravity varied in my cases between 1.0064 and 1.0070 , and according to other anthors, it varies between 1.001 and 1.008.

\section{Viscosity}

Polanyi found the viscosity to vary between 1.020 and 1.027 at a temperature of $38^{\circ} \mathrm{C}$., taking the viscosity of water as 1 . 1 examined the viscosity of several cerebrospinal fluids, by means of the Ostwald apparatus, and found it to vary between 1.0424 and 1.0489 compared to water.

\section{Conductivity}

Polanyi examined the conductivity of the cerebrospinal fluid of hydrocephalus and found it to be $0.01136 ; 0.01280$;

1

0.01527 ; and 0.01452 at $20^{\circ} \mathrm{C}$. (Formula - ).

$\mathrm{Ohm} \times \mathrm{Cm}$.

My examination gave the conductivity as .01513, .01365, and .01513 at $25^{\circ} \mathrm{C}$.

\section{Surface Tension}

Polanyi found the surface tension to be $7.35,7.15,7.16$ and 7.20 dynes at $20^{\circ} \mathrm{C}$.

\section{Freezing Point}

Grenet found the freezing point of normal cerebrospinal fluid to be $-.38^{\circ}$ to $-.56^{\circ} \mathrm{C}$. Quincke found it to be $-.56^{\circ}$ to $-.75^{\circ}$. Polányi found it to be $-.566^{\circ},-.570^{\circ},-.678^{\circ}$, $-.583^{\circ}$. Mott found it to be $-.51^{\circ}$ to $-.56^{\circ}$. Mestrezat found the average to be $-.576^{\circ}$, with the extremes varying between $-.57^{\circ}$ and $-.59^{\circ}$. My findings showed the freezing point to vary between $-.56^{\circ}$ and $-.58^{\circ}$. In general it must be said here also that the interval between the removal of 
the cerebrospinal fluid from the body, and the time of the examination is a great factor; although the variation in the freezing point on standing is not nearly as much as is the case with H-ion concentration, or with the alkali reserve.

\section{Refractometric Index}

Polányi found the refractometric index to be 1.3499 at $23^{\circ} \mathrm{C} ., 1.33516$ at $21^{\circ} \mathrm{C}$, 1.33579 , at $20.3^{\circ} \mathrm{C}$, and 1.33554 at $20^{\circ} \mathrm{C}$. I found it to be 1.73516 at $23^{\circ} \mathrm{C}$.

\section{Reaction of Normal Cerebrospinal Fluid}

All through the older, writings, the statement is found that the cerebrospinal fluid is alkaline in reaction, the alkalinity being given as a rule as half that of the blood. Cavazzani examined the fluid of two cases of hydrocephalus, and found a neutral reaction. Concetti found the fluid alkaline three times, and weakly alkaline four times. Von Jaksch found the alkalinity to equal 20 c.e. of $n / 10$ acid solution.

Kafka used $\mathrm{n} / 10 \mathrm{HCl}$ and cochineal as an indicator, and found that on an average, 20 c.e. of acid was necessary to neutralize 100 c.c. of fluid. According to Mott, the alkalinity of the fluid corresponds to 0.1 per cent of sodium hydrate.

Of late, the entire conception of the reaction of body fluids has changed due mainly to the work of Michaelis, Sörenson, Henderson and Van Slyke. The reaction of body fluids is now spoken of in terms of hydrogen and hydroxyl ions, which is expressed either in the terms of hydrogenion concentration, or in terms of $\mathrm{P}_{\mathrm{H}}$, the latter term indieating the negative exponent of the hydrogen-ion concentration, for instance $P_{H} 7.1=1 \times 10^{-7.1} \mathrm{~N}$. The H-ion concentration can be determined in a number of ways, the most important of which are the compensation method of Michaelis or of Hildebrandt, and the indicator method of Sörenson. Practically all of these methods have been used 
recently for the study of the cerebrospinal fluid. The results, however, have not been uniform. Bisgaard examined the fluid against a borate mixture, 5.7 plus $\mathrm{HCl}$, and found that the fluid was more acid than the borate mixture. Polányi determined the H-ion concentration of one fluid drawn from a case of hydrocephalus, by the compensation method with the use of the Farkas-Szilisch electrode. He formd the H-ion concentration to be 9.084 $\times 10$. Hurwitz and Tranter, who used the Levy Rowntree-Marriott standards, found the $\mathrm{P}_{\boldsymbol{H}}$ of normal fluids to vary between 8.15 and 8.30 with an average of 8.26 , this being somewhat lower when the fluid was dialyzed, the average then being 8.11. Weston found the dialyzed fluid to vary between 7.9 and 8.3 with an average of 8.12 .

I have examined the H-ion concentration in over four hundred normal cerebrospinal fluids, or to be more accurate, fluid from cases that proved to be nonmeningitic in character. The series includes cases of neplritis, gastrointestinal intoxication, pneumonia, paresis, alcoholic psychosis, dementia precox, brain tumor, epilepsy and many other conditions. I used the methods of Michaelis and Hildebrandt for the determination of old fluids and the Levy-RowntreeMarriott method, or an indicator corresponding to this method, in fresh fluid. I found that when the fluid is examined immediately after its withdrawal from the body, the H-ion concentration expressed in terms of $P_{H}$ ranges from 7.4 to 7.6. In only two cases have I found an H-ion concentration of fresh fluid to be 7.7. However, if the fluid has been standing a short while, the reaction changes very quickly toward the alkaline side. As a rule, standing half an hour changes the reaction to a $P_{\mathrm{H}}$ of 7.5 to 7.6 ; standing one hour changes the reaction to a $P_{\text {н }}$ of 7.7 ; standing two hours changes it to 7.9 or 8.0. From two hours on, the change in the reaction toward the alkaline side is rather small, some fluids changing in twelve hours to 8.1, and remaining at this concentration no matter how long it stays; 
TABLe XII

H-ion Concentration of Normal Cerebrospinal Fluid by Other authors

\begin{tabular}{|c|c|c|c|c|}
\hline ALTHOR & METHON & \multicolumn{2}{|c|}{$P_{H}$} & \multirow{2}{*}{ REMARKS } \\
\hline AUTHOTE & FMPLOYED & \multirow{2}{*}{\multicolumn{2}{|c|}{$\begin{array}{l}\text { FRESH } \\
\begin{array}{l}\text { Neutral } \\
\text { Interval of standing not in- } \\
\text { dicated. }\end{array}\end{array}$}} & \\
\hline Cavazzani & $\begin{array}{l}\text { Tartarle } \\
\text { acid }\end{array}$ & & & $\begin{array}{l}2 \text { cases of hydro- } \\
\text { cephalus also dogs }\end{array}$ \\
\hline Concetti & & $\begin{array}{l}\text { Alkaline } 3 \\
\text { acid } 1 \text { time. } \\
\text { Interval of st } \\
\text { dicated. }\end{array}$ & $\begin{array}{l}\text { mes, weakly } \\
\text { nding not in- }\end{array}$ & \\
\hline Myers & Litmus & Neutral or fa & ntly alkaline & \\
\hline Bisgaard & $\begin{array}{l}\text { Phenol- } \\
\text { phthalein }\end{array}$ & $\begin{array}{c}\text { Less than } \\
8.1\end{array}$ & & \\
\hline Kopetzky & Litmus & Less than 8.0 & & \\
\hline Turner & $\begin{array}{l}\text { Phenol- } \\
\text { phthalein }\end{array}$ & Aeid & & $\left\{\begin{array}{l}\text { Fluid in stoppered } \\
\text { bottles retained } \\
\text { acidity } \\
\text { Fluid in unstopper } \\
\text { ed bottles beeame } \\
\text { alkaline }\end{array}\right.$ \\
\hline Polányi & $\begin{array}{l}\text { Farkas- } \\
\text { Szilisch } \\
\text { electrode }\end{array}$ & & 9.0 & \\
\hline $\begin{array}{l}\text { Hurwitz } \\
\text { and } \\
\text { Tranter }\end{array}$ & $\begin{array}{l}\text { Levy- } \\
\text { Rowntree- } \\
\text { Marriott } \\
\text { method }\end{array}$ & & $\begin{array}{l}8.15 \\
8.30 \\
\text { average- } \\
8.1\end{array}$ & \\
\hline Weston & $\begin{array}{l}\text { Levy- } \\
\text { Rowntree- } \\
\text { Narriott } \\
\text { method }\end{array}$ & & $\begin{array}{l}79-8.3 \\
\text { average- } \\
8.12\end{array}$ & \\
\hline $\begin{array}{l}\text { Felton, } \\
\text { Hussey } \\
\text { and } \\
\text { Bayne- } \\
\text { Jones }\end{array}$ & $\begin{array}{l}\text { Levy- } \\
\text { Rowntree- } \\
\text { Marriott } \\
\text { method }\end{array}$ & $7.7-7.9$ & 8.6 & \\
\hline
\end{tabular}

other fluids clanging to 8.3 or eren 8.6 in course of twentyfour hours or longer.

In Table XI, I give the H-ion concentration in some of my cases showing average results, indicating the method used by the letters a, b, c; "a" represents the gas-chain method, "b" the alkalinized phenolphthalein compared to the Sörenson standards, and "c" the Levy-Rowntree-Marriott indicator compared to the standard colorimetric tubes. A typical change in the $H$-ion concentration is illustrated 
in the curve shown in Fig. 20. The results olltained by phenolphthalein compared to the Sörenson standards, are often marked with an additional + and - signs. This means that $P_{\mathrm{r}}$ of the cerebrospinal fluid was higher or lower than the figure given, but how high or how low was not determined.

These findings have been so constant that I believe we can account for the high $P_{n}$ obtained in normal cerebrospinal fluid by the authors quoted. They examined the

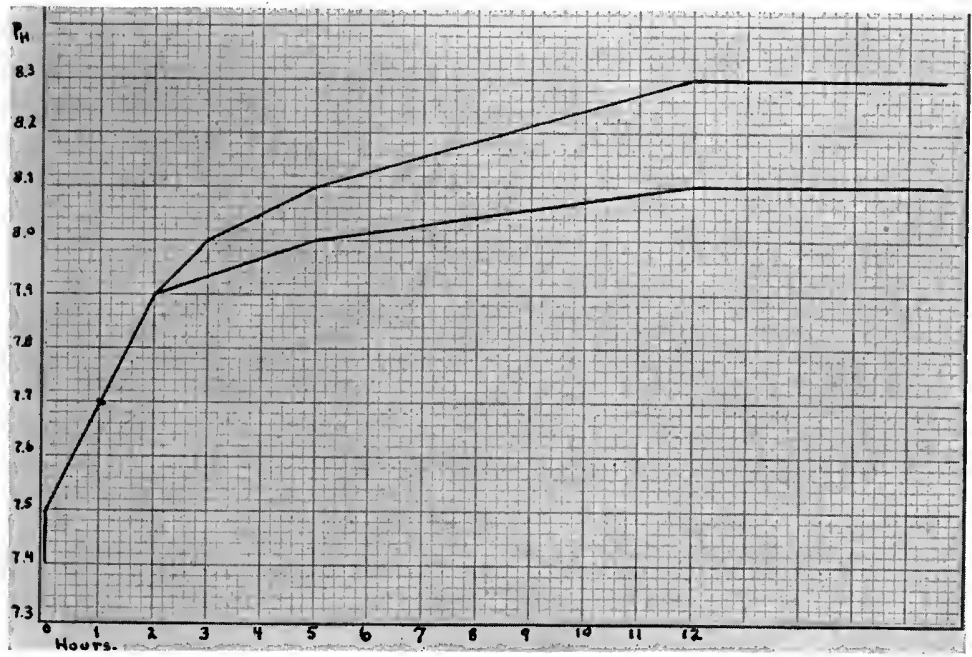

Fig. 20.-Average change in the $\mathrm{H}$-ion concentration of nonmeningitic fluid on standing.

fluid after it had been standing for some time, which naturally gave a very low $\mathrm{H}$-ion concentration, or a high $\mathrm{P}_{\mathrm{H}}$. Interesting in this connection is the work of John Thrner who not only knew of the high H-ion concentration of the fluid, but was also aware of the fact that the concentration changes on standing. To quote him:

"In all the cases of this series and in twenty examined fifteen years ago, I have obtained an alkaline reaction (and not amphoteric) to litmus paper, but with phenolphthalein the great majority have an acid reaction. The de- 
TABLE XIII

H-Ion Coxcentration of Noymenixgitic Spixal Fluid

\begin{tabular}{|c|c|c|c|c|c|}
\hline \multirow[b]{2}{*}{ CASE } & \multirow[b]{2}{*}{ DIAGXOSIB } & \multicolumn{4}{|c|}{$P_{H}$} \\
\hline & & Immediate & $1 / 2$ Hour & 1 Hour & 2 Hours \\
\hline 1 & Little's disease........... & . & ... & & \\
\hline 2 & Tetanus............... & $\cdots$ & & & \\
\hline $\begin{array}{l}3 \\
4\end{array}$ & Pneumonia. $1 \ldots \ldots \ldots$ &. & $\cdots \cdots$ & $\cdots$ & …....... \\
\hline $\begin{array}{l}4 \\
5\end{array}$ & & $\ldots .$. & $\cdots \cdots \cdots \cdots$ & $\cdots \ldots \ldots$ & $\ldots \ldots \ldots$ \\
\hline 6 & 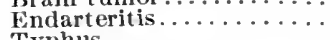 & $\cdots \cdots$ & $\cdots \cdots \cdots \cdots$ & $\cdots \cdots \cdots \cdots$ & $\cdots \ldots \ldots \ldots$ \\
\hline $\begin{array}{l}7 \\
8\end{array}$ & Typhus............... & $\cdots \cdots$ & .... & $\cdots$ & \\
\hline $\begin{array}{l}8 \\
9\end{array}$ & 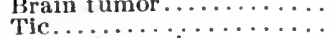 & $\begin{array}{l}\cdots \cdots \\
\cdots \cdots\end{array}$ & $\ldots \ldots$ & $\cdots$ & $8.0{ }^{\circ}(\mathrm{b}){ }^{\circ}$ \\
\hline 10 & General paresis......... & $\ldots \ldots$ & & & $8.0 \quad$ (b) \\
\hline 11 & Delirium tremens....... & $\ldots \ldots$ & & & $\ldots \ldots \ldots$ \\
\hline $\begin{array}{l}12 \\
13\end{array}$ & General paresis.... & & ‥ & $\cdots \cdots$ & $\ldots \ldots \ldots \ldots$ \\
\hline $\begin{array}{l}13 \\
14\end{array}$ & Tubercle of brain.......... & $7.4^{\cdots}(b)$ & & $\cdots \cdots$ & $\cdots \ldots \ldots$ \\
\hline 15 & Juvenile paresis......... & 7.4 (b) & & & 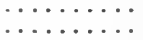 \\
\hline 16 & Alcoholic . . . . . . . . . & $\ldots \ldots \ldots \ldots$ & $7.4+(\mathrm{b})$ & & $\ldots \ldots \ldots$ \\
\hline 17 & General paresis........ & ........ & $7.4+(b)$ & & .......... \\
\hline 18 & $\begin{array}{l}\text { Alcoholic } \ldots \ldots \ldots \ldots \\
\text { Paranoia..... }\end{array}$ & 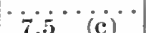 & $\cdots \cdots \cdots$ & $\cdots$ & $\cdots \cdots \cdots$ \\
\hline $\begin{array}{l}19 \\
20\end{array}$ & $\begin{array}{l}\text { Paranoia } \ldots \ldots \ldots \\
\text { Epilepsy } \ldots \ldots \ldots\end{array}$ & 7.4 (c) & & & …...... \\
\hline $\begin{array}{l}20 \\
21\end{array}$ & Epilepsy.... & $\ldots \ldots \ldots$ & $7.5{ }^{\circ}(\mathrm{c})$ & $\cdots \cdots \cdots \cdots$ & $\cdots \cdots \cdots$ \\
\hline 22 & C. Sp. Lues ?.......... & $\ldots \ldots \ldots$ & $\ldots \ldots \ldots$ & $7.9^{\circ}(\mathrm{c})$ & $\ldots \ldots \ldots \ldots$ \\
\hline 23 & 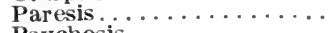 & ......... & $\ldots \ldots \ldots$ & $7.7 \quad$ (c) & .......... \\
\hline 24 & Psychosis.. & & ... & 7.7 (c) & . $\ldots \ldots \ldots$ \\
\hline 25 & Psychosis.. & $7.5 \quad$ (c) & $\cdots \cdots$ & $\ldots \ldots \ldots \ldots$ & $\ldots \ldots \ldots \ldots$ \\
\hline 26 & $\ldots \ldots$ & $7.6 \quad(c)$ & $\ldots \ldots \ldots$ & ........... & $\ldots \ldots \ldots$ \\
\hline 27 & Psychosis............. & & $\cdots \cdots$ & … & …..... \\
\hline $\begin{array}{l}28 \\
29\end{array}$ & 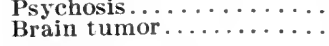 & $\ldots \ldots \ldots$ & $\cdots$ & $\cdots \cdots$ & $8.0 \cdots(c)$ \\
\hline 30 & Pneumonia............ & & & & 8.0 (b) \\
\hline 31 & Alcoholi & & $7.4 \quad(\mathrm{c})$ & $7.5{ }^{\circ}(\mathrm{c})$ & $\ddot{7}^{\cdots}(\mathrm{c})^{\cdots}$ \\
\hline 32 & Gene & (c) & $\ldots \ldots \ldots$ & $\ldots \ldots \ldots$ & $\ldots \ldots \ldots$ \\
\hline 33 & Psyc & 7.7 & . & $\ldots \ldots \ldots$ & $\ldots \ldots \ldots$ \\
\hline 34 & & & $\ldots \ldots \ldots$ & $\ldots \ldots \ldots$ & .......... \\
\hline 35 & Alcoholic. . . . . . & $7.4 \quad$ (c) & $\cdots \ldots \ldots$ & $\ldots \ldots \ldots$ & $\cdots \ldots \ldots$ \\
\hline $\begin{array}{l}36 \\
37\end{array}$ & …… & $7 \cdot 4 \quad$ (c) & $\cdots \cdots \cdots$ & $\cdots \cdots \cdots$ & ….... \\
\hline 38 & 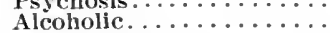 & $7.5 \quad$ (c) & …m. & $\cdots \cdots \cdots$ & $\cdots \cdots \cdots$ \\
\hline 39 & lic $\ldots \ldots \ldots \ldots \ldots$ & (c) & $\cdots \cdots \cdots \cdots$ & $\cdots \cdots$ & ann. \\
\hline 40 & General paresis.. & $7.5 \quad$ (c) & & & \\
\hline 41 & Psychosis...... & $7.4 \quad$ (c) & $7.6 \quad(\mathrm{c})$ & $\ldots \ldots \ldots$ & $\ldots \ldots \ldots \ldots$ \\
\hline $\begin{array}{c}\text { Mixture } \\
42\end{array}$ & 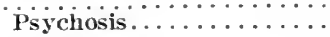 & $\begin{array}{ll}7.4 & (\mathrm{c}) \\
7.4 & (\mathrm{c})\end{array}$ & $\begin{array}{l}7.8 \quad(\mathrm{c}) \\
\ldots \ldots\end{array}$ & & $\ldots \ldots \ldots \cdots$ \\
\hline 43 & Psyc & 7.5 & & & \\
\hline Mixture & Psychosis........... & $7.4 \quad(\mathrm{c})$ & & $\cdots \ldots \ldots \ldots$ & ......... \\
\hline Mixture & & 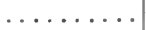 & 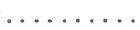 & & $\ldots \ldots \ldots$ \\
\hline 44 & Poliomyelitis.. & & & $7.7 \quad$ (c) & \\
\hline$\underset{45}{\stackrel{\text { Mixture }}{4}}$ & General paresis & $7.4 \quad(\mathrm{c})$ & $\cdots$ & $\cdots \cdots \cdots$ & $\cdots \cdots$ \\
\hline 46 & 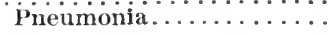 & $77^{\circ}(\mathrm{c})$ & 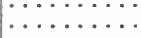 & $\cdots$ & ……? \\
\hline$\underset{47}{\operatorname{Mixt}}$ & $\cdots \cdots \cdots \cdots \cdots$ & $7.4 \quad$ (c) & $\cdots$ & $\cdots$ & $\cdots \cdots$ \\
\hline 48 & Psychosis... & $7.5 \quad$ (c) & ann & $\ldots \ldots \ldots$ & $\ldots$. \\
\hline $\begin{array}{l}49 \\
50\end{array}$ & Meningism $\ldots . . . .$. & $7.5 \quad(\mathrm{c})$ & $\because 6 \cdots$ & $\cdots \cdots \cdots$ & $\cdots \cdots \cdots$ \\
\hline & & & 7.6 & & \\
\hline
\end{tabular}

gree of acidity, howerer, is in many cases very slight. A very faint pink solution of phenolphthalein was poured into two small beakers, so that the tint in both was similar 
PROPERTIES OF NORMAL CEREBROSPINAL FLUID

TABLE XIII-Continued

H-Ion Concentration of Nonmeningitic Spinal FuUid

\begin{tabular}{|c|c|c|c|c|c|c|}
\hline \multicolumn{7}{|c|}{$P_{H}$} \\
\hline 3 Hours & 4 Hours & 5 Hours & 12 Hours & 18 Hours & 24 Hours & 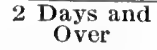 \\
\hline & & & & & & 8.56 (a) \\
\hline & $\cdots$ & & & $\ldots$ & $\ldots \ldots \ldots$ & 8.14 (a) \\
\hline$\cdots$ & $\cdots \cdots$ & . & $\cdots$ & $\cdots \cdots$ & $\ldots \ldots \ldots$ & 8.6 (a) \\
\hline & & & & & & 9.08 (a) \\
\hline$\cdots$ & & & $\cdots$ & & & 8.3 \\
\hline & $\therefore$ & & $\cdots$ & & $8.0+(b)$ & $\begin{array}{r}7.89 \text { (a) } \\
\ldots .\end{array}$ \\
\hline & & & & & $8.6-(b)$ & a......... \\
\hline$\because$ & & & & & ............. & $8.6-(b)$ \\
\hline$\cdots$ & ….... & $\cdots \cdots$ & $\cdots \cdots \cdots$ & $\cdots \cdots$ & $\cdots \cdots \cdots$ & ........... \\
\hline & & & & & $8.0+(b)$ & $\cdots \cdot$ \\
\hline & & & $\because \cdots$ & & .......... & $8.6-$ (b) \\
\hline$\because$ & $\cdots$ & $8.6-(b)$ & $\begin{array}{l}8.0 \quad(b) \\
\ldots \ldots \ldots\end{array}$ & & $\cdots \cdots$ & 21,2 \\
\hline . & .. & $\ldots \ldots \ldots$ & $\ldots \ldots \ldots$ & $\cdots$ & $\ldots$ & $\ldots \ldots \ldots$ \\
\hline & $\cdots \cdots \cdots$ & & & & $\cdots \cdots$ & ............ \\
\hline & $8.0(c)$ & & & $\cdots$ & $\cdots$ & $\cdots \cdots$ \\
\hline$\cdots$ & $\cdots \cdots \cdots$ & & & $\cdots \cdots$ & $\cdots$ & ……... \\
\hline$\cdots$ & & & & & $\cdots$ & $\cdots \cdots$ \\
\hline$\ldots$ & . & $\cdots$ & $\cdots \cdots$ & $\because$ & $\cdots$ & n......... \\
\hline$\cdots$ & . & $\ldots \ldots \ldots$ & $\ldots \ldots$ & $\ldots$ & $\ldots$ & an. \\
\hline & $\cdots$ & $8.0{ }^{\cdots}(\mathrm{c})$ & & $\begin{array}{l}\cdots \ldots \ldots \ldots \\
\cdots \ldots \ldots\end{array}$ & $\ldots \ldots \ldots \ldots$ & ${ }_{8,4}{ }^{\prime}{ }_{(c)}{ }^{\cdots}$ \\
\hline . & $\cdots$ & $\ldots \ldots \ldots$ & & & $\ldots$ & $\ldots \ldots \ldots$ \\
\hline$\ldots$ & $\cdots$ & $\ldots \ldots \ldots$ & & $\cdots$ & $\cdots$ & $\ldots \ldots \ldots$ \\
\hline$\cdots$ & & $\cdots$ & $\cdots$ & $\cdots$ & $\cdots$ & .......... \\
\hline & & & & & & $\cdots \cdots$ \\
\hline . & & $8.0 \cdots(c)$ & $8 i^{\prime c}$ & $8 i^{\cdots}(c)$ & $\cdots$ & $8.2 \quad(\mathrm{c})$ \\
\hline - & & $\ldots \ldots \ldots$ & & $\ldots \ldots \ldots$ & & $\cdots \cdots$ \\
\hline & & & & $\cdots \cdots$ & & $\ldots$ \\
\hline . & & & $8 . i^{\cdots}(a)$ & & & $\cdots$ \\
\hline & $\ldots \ldots$ & $\ldots \ldots \ldots$ & $\ldots \ldots \ldots$ & $\ldots \ldots$ & $\ldots$ & $\ldots \ldots$ \\
\hline & & & & & & $\cdots$ \\
\hline & & & $\cdots$ & $\cdots$ & & ( \\
\hline & $\cdots$ & $\ldots . . . \ldots$ & & & $\cdots$ & $\ldots \ldots$ \\
\hline & 8.1 & ${ }_{8.1} \cdots(\mathrm{c})$ & ${ }_{s i}{ }^{\cdots}(\mathbf{c})$ & …....... & & $\cdots \cdot$ \\
\hline & & & & $8.1^{\text {(a) }}$ & & $\ldots \ldots$ \\
\hline & & & & $8.1 \quad(\mathbf{c})$ & & \\
\hline & & & & 8.1 & & \\
\hline & & & & & & \\
\hline & & & & (c) & & \\
\hline & & & & 8.1 & & \\
\hline & & 8.1 & & $\ldots \ldots \ldots$ & $\ldots \ldots \ldots \ldots$ & $\cdots$ \\
\hline & & 8.1 & & & $8.2{ }^{\prime}(a)$ & $8.1 \ldots \ldots$ \\
\hline & & & $8.1 \quad(\mathrm{a}$ & & $\cdots \cdots \cdots$ & \\
\hline & & & & & 8.2 & \\
\hline & & & & & $\cdots \cdots$ & $\cdots$ \\
\hline & & & & & $\cdots$ & $\cdots$ \\
\hline
\end{tabular}

* Corked.

in looking down at them as they stood upon a porcelain slab. A little of the fhuid was then added to one beaker and generally the pink color was immediately discharged. I 
found that the fluid left unstoppered in my room, where gas is constantly burning, rapidly becomes alkaline, whereas similar fluid in stoppered bottles retained its acidity, and that in my later examinations where this source of fallacy was recognized and excluded, the results tend more and more to be uniformly acid with phenolphthalein.",

I have endeavored to find the factors that are responsible for the changes taking place in the $\mathrm{H}$-ion concentration of nonmeningitic cerebrospinal fluid. I found that when I put a part of the cerebrospinal fluid right after its withdrawal from the body into a desiccator containing twenty per cent sodium hydrate, and allowed it to remain in the desiccator from ten to thirty mimutes, the acidity of the fluid was greatly decreased, the $P_{H}$ being in a very short time 7.7 to 7.9 .

TABLE XIV

Cutajges in II+ Concentration on Removal of COg by lixposure to Al,kali in DESICCATOR

\begin{tabular}{|c|c|c|c|c|c|c|}
\hline CASE & FLUID DRAWN & $\begin{array}{l}\text { PII } \\
\text { MM- } \\
\text { MEDI- } \\
\text { ATELY }\end{array}$ & $\begin{array}{c}\text { EXPOSED TO } \\
\text { AL KALI }\end{array}$ & $\begin{array}{l}\text { EXPOSED TO } \\
\text { AIR }\end{array}$ & EXAMINED & Pн. \\
\hline 190 & $6: 55$ p. m. & 7.4 & 12 minutes & & $\begin{array}{l}7: 07 \text { p. m. } \\
7: 15 \text { p. m. }\end{array}$ & $\begin{array}{c}7.7 .7 .8 \\
7.8\end{array}$ \\
\hline 190 & $6: 55$ p. m. & 7.4 & 20 minutes & $\begin{array}{l}7 \text { minutes after } \\
20 \text { minites } \\
\text { exposure to } \\
\text { alkali }\end{array}$ & $7: 22 \mathrm{pm}$. & $7.8-7.9$ \\
\hline 190 & $6: 55$ p. m. & 7.4 & 27 minures & $\begin{array}{l}38 \text { minutes after } \\
27 \text { minutes } \\
\text { exposure to } \\
\text { alkali }\end{array}$ & 7:55 p. m. & $7.8-9$ \\
\hline $\begin{array}{l}190 \\
188 \\
188 \\
188 \\
186 \\
186\end{array}$ & $\begin{array}{l}6: 55 \text { p. } \mathrm{m} . \\
7: 03 \text { p. } \mathrm{m} . \\
7: 03 \text { p. } \mathrm{m} . \\
7: 03 \text { p. } \mathrm{m} . \\
7: 45 \text { p. } \mathrm{m} . \\
7: 45 \text { p. } \mathrm{m} .\end{array}$ & $\begin{array}{l}7.4 \\
7.4 \\
7.4 \\
7.4 \\
7.4 \\
7.4\end{array}$ & $\begin{array}{l}20 \text { minutes } \\
10 \text { minutes } \\
30 \text { minutes } \\
30 \text { minutes } \\
6 \text { minutes } \\
25 \text { minutes }\end{array}$ & $\begin{array}{l}13 \text { hours } \\
3 \text { minutes }\end{array}$ & $\begin{array}{r}11: 22 \text { a. m. } \\
7: 13 \text { p. m. } \\
7: 33 \text { p. m. } \\
7: 36 \text { p. m. } \\
7: 51 \text { p.in. } \\
8: 10 \text { p. m. }\end{array}$ & $\begin{array}{c}8.1 \\
7.7 \cdot 7.8 \\
7.8 \\
7.8 \\
7.6 \cdot 7.7 \\
7.9\end{array}$ \\
\hline
\end{tabular}

This shows that the removal of $\mathrm{CO}_{2}$ from the fluid causes a decrease in the H-ion concentration of the fluid. To make certain, however, that the increase in the $\mathrm{P}_{\mathrm{H}}$ of the cerebrospinal fluid is entirely dne to $\mathrm{CO}_{2}$, I performed the following experiment. I divided a fluid into two portions: one portion I corked tightly after its removal from the body, and coated with a layer of paraffin, and the other portion I left in a nonsol glass tube. The two portions of 
the fluid were examined twenty-four hours later. I found that the fluid which had been corked very tightly retained the original H-ion concentration, giving a $\mathrm{P}_{\mathrm{H}}$ of 7.4 to 7.6 in twenty-four hours; while the fluid that had been left in a cotton plugged test tube gave a $\mathrm{P}_{\mathrm{II}}$ of 8.1 or higher in twenty-four hours, which is the ordinary change taking place in cerebrospinal fluid. This shows that the decrease in the H-ion concentration in the cotton-plugged tube was not due to formation of ammonia or other alkaline substance, but to the loss of $\mathrm{CO}_{2}$ from the fluid into the air. I have furthermore shown that when the tube containing

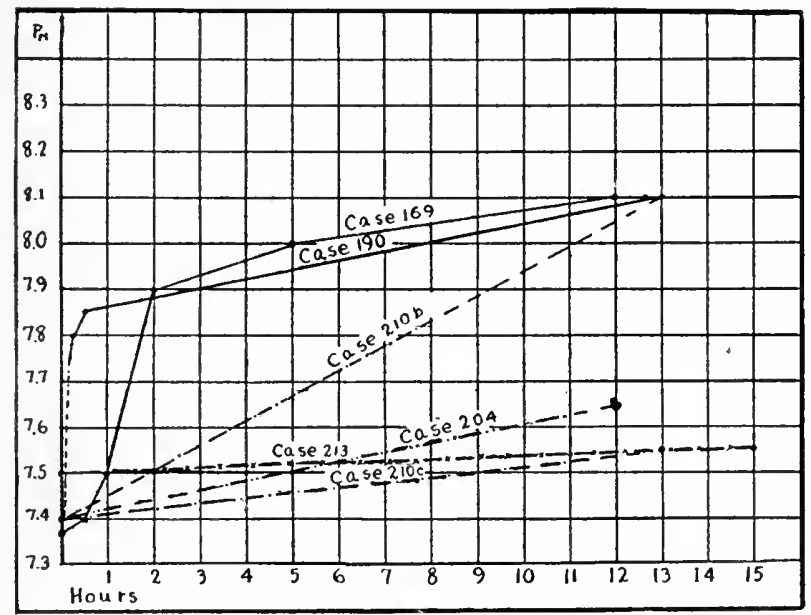

Fig. 21.- Change in IIt concentration of nonmeningitic fluids on standing at room temperature under various conditions. Case 169. Plugged with cotton. Case 190. Immediately after withdrawal, exposed to $\mathrm{CO}_{2}$ free air in desiccator (dotted line) and later left with cotton plug. Case $210 \mathrm{~b}$. Plugged with cotton; Case $210 \mathrm{c}$, the same fluid as b, but corked with a cork-a few bubbles at the top. Case 204. Six c.c. tube, half filled, and tightly corked; cotton plugged fluid was same as Case 210b (8.1). Case 213. Almost perfectly sealed with cork, without any air bubble above the fluid.

fluid is eorked tightly, but some space is left between the fluid and the cork, there will be some change in the H-ion concentration of the fluid, the H-ion decreasing slightly although not nearly as much as the fhuid standing in the cotton-plugged tube (Table XV) (Fig. 21). I have also measured the total carbonates in fresh and old fluid and found it to run parallel with the H-ion concentration as 
TABLE XV

H Concentratos of Fludos Standing in Corked Tubes

\begin{tabular}{|c|c|c|c|c|c|c|c|}
\hline $\begin{array}{l}\text { XU:- } \\
\text { BER }\end{array}$ & $A G E$ & DIAG Yosis & DATE DRAWX & $\begin{array}{c}\text { DATE } \\
\text { EXAMINED }\end{array}$ & INTERVAL & $\begin{array}{c}\text { STOPPERED } \\
\text { WITH }\end{array}$ & $\mathrm{P}_{\mathrm{H}}$ \\
\hline$\underset{210 a}{\text { Mixture }}$ & $\begin{array}{l}27 \\
38\end{array}$ & $\begin{array}{l}\text { Alcoholic } \\
\text { Alcoholic }\end{array}$ & $\begin{array}{l}\text { p.m. } \\
6 / 25 / 17-7: 15 \\
6 / 25 / 17-7: 20\end{array}$ & $\begin{array}{l}\text { p.m. } \\
6 / 25 / 17-7: 15 \\
6 / 25 / 17-7: 20\end{array}$ & $\begin{array}{l}\text { Immediately } \\
\text { Immediately }\end{array}$ & & $\begin{array}{l}7.4 \\
7.4\end{array}$ \\
\hline $210 \mathrm{~b}$ & $\begin{array}{l}27 \\
38\end{array}$ & $\begin{array}{l}\text { Alcoholic } \\
\text { Alcoholic }\end{array}$ & $\begin{array}{l}6 / 5 / 17-7: 15 \\
6 / 25 / 17-7: 20\end{array}$ & $\begin{array}{r}\text { a.m. } \\
6 / 26 / 17-8: 00\end{array}$ & 13 hours & Cotton & 8.1 \\
\hline $210 \mathrm{c}$ & $\begin{array}{l}27 \\
38\end{array}$ & $\begin{array}{l}\text { Alcoholic } \\
\text { Alcoholic }\end{array}$ & $\begin{array}{l}6 / 25 / 17-7: 15 \\
6 / 25 / 17-7: 20\end{array}$ & $6 / 26 / 17-8: 00$ & 12 hours & $\begin{array}{l}\text { Paraffined cork } \\
\text { (few bubbles } \\
\text { below cork) }\end{array}$ & $7.5-7.6$ \\
\hline $211 \mathrm{a}$ & $\begin{array}{l}43 \\
46\end{array}$ & $\begin{array}{l}\text { Alcoholic } \\
\text { Alcoholic }\end{array}$ & $\begin{array}{l}6 / 25 / 17-7: 28 \\
6 / 25 / 17-7: 37\end{array}$ & $\begin{array}{l}6 / 25 / 17 \\
6 / 25 / 17\end{array}$ & $\begin{array}{l}\text { Immediately } \\
\text { Immediately }\end{array}$ & & 7.5 \\
\hline $211 b$ & $\begin{array}{l}43 \\
46\end{array}$ & $\begin{array}{l}\text { A]coholic } \\
\text { Alcoholic }\end{array}$ & $\begin{array}{l}6 / 25 / 17-7: 28 \\
6 / 25 / 17-7: 37\end{array}$ & $6 / 26 / 17-8: 10$ & $121 / 2$ hours & Cotton & 8.1 \\
\hline $211 \mathrm{c}$ & $\begin{array}{l}43 \\
46\end{array}$ & $\begin{array}{l}\text { Alcoholic } \\
\text { Alcoholic }\end{array}$ & $\begin{array}{l}6 / 25 / 17-7: 28 \\
6 / 25 / 17-7: 37\end{array}$ & $6 / 26 / 17-8: 10$ & $121 / 2$ hours & Paraffined cork & $7.5-7.6$ \\
\hline $211 d$ & 46 & $\begin{array}{l}\text { Alcoholic } \\
\text { Alcoholic }\end{array}$ & $\begin{array}{l}6 / 25 / 17-7: 28 \\
6 / 25 / 17-7: 37\end{array}$ & $6 / 26 / 17-11: 17$ & $151 / 2$ hours & $\begin{array}{l}\text { Paraffined cork } \\
\text { replaced after } \\
3 \text { c.c. removed } \\
\text { for exam. at } \\
8: 10 \text {, leaving } \\
3 \text { c.c. space in } \\
6 \text { c.c. tube. }\end{array}$ & 7.6 \\
\hline 212 & 55 & Alcoholic & $6 / 25 / 17-7: 48$ & $6 / 25 / 17-7: 52$ & 4 minutes & & 7.4 \\
\hline $\mathbf{b}$ & 55 & Alcoholic & $6 / 25 / 17-7: 48$ & $6 / 26 / 17-11: 05$ & 15 hours & Paraffined cork & $7.5-7.6$ \\
\hline c & 55 & Alcoholic & $6 / 25 / 17-7: 48$ & $6 / 26 / 17-11: 30$ & 15 hours & Cotton & 8.2 \\
\hline d & 55 & Alcoholic & $6 / 25 / 17-7: 48$ & 6/28/17 -12:30 & & Cotton & 7.9 \\
\hline 213 & 39 & Alcoholic & $6 / 25 / 17-8: 00$ & $6 / 25 / 17-8: 02$ & 2 minutes & & 7.5 \\
\hline b & 39 & Alcoholic & $6 / 25 / 17-8: 00$ & $6 / 26 / 17-11: 25$ & $151 / 2$ hours & Paraffined cork & $7.5-7.6$ \\
\hline 218 & $1 \mathrm{yr}$. & Pneumonia & $6 / 26 / 17-1: 30$ & $6 / 26 / 17-1: 30$ & Immediately & & $7.5-7.6$ \\
\hline b & $1 \mathrm{yr}$. & Pneumonia & $6 / 26 / 17-1: 30$ & $6 / 28 / 17-12: 30$ & 47 hours & Paraffined cork & $7.5-7.6$ \\
\hline c & $1 \mathrm{yr}$. & Pneumonia & $6 / 26 / 17-1: 20$ & $6 / 28 / 17-12: 30$ & 47 hours & Cotton & 8,2 \\
\hline 204 & $\begin{array}{l}46 \\
42 \\
38\end{array}$ & $\begin{array}{c}\text { Pulmonary } \\
\text { tuberculosis } \\
\text { Alcoholic } \\
\text { General } \\
\text { paresis }\end{array}$ & $\begin{array}{l}6 / 18 / 17-7: 15 \\
6 / 18 / 17-7: 20 \\
6 / 18 / 17-7: 30\end{array}$ & $6 / 18 / 17-7: 30$ & $\begin{array}{l}15 \text { minutes } \\
10 \text { minute; } \\
\text { Immediately }\end{array}$ & & 7.4 \\
\hline $\mathbf{b}$ & 38 & $\begin{array}{l}\text { General } \\
\text { paresis }\end{array}$ & $6 / 18 / 17-7: 30$ & $6 / 19 / 17-\underset{\text { a.m. }}{7: 30}$ & 12 hours & Cotton & 8.1 \\
\hline c & 38 & $\begin{array}{l}\text { General } \\
\text { paresis }\end{array}$ & $6 / 18 / 17-7: 30$ & $6 / 19 / 17-7: 30$ & 12 hours & $\begin{array}{l}\text { Paraffin; left } 3 \\
\text { c.c. s p a ce } \\
\text { above volume } \\
\text { of liquid. }\end{array}$ & $7.6-7.7$ \\
\hline 205 & $\begin{array}{l}29 \\
34 \\
36\end{array}$ & $\begin{array}{l}\text { Alcoholic } \\
\text { Alcoholic } \\
\text { Alcoholic }\end{array}$ & $\begin{array}{l}6 / 18 / 17-7: 40 \\
6 / 18 / 17-7: 45 \\
6 / 18 / 17-7: 53\end{array}$ & 6/18/17 - $\begin{array}{c}\text { p.m. } \\
7: 53\end{array}$ & $\begin{array}{l}11 \text { minutes } \\
8 \text { minutes } \\
\text { Immediately }\end{array}$ & & 7.4 \\
\hline b & 36 & Alcoholic & $6 / 18 / 17-7: 53$ & $6 / 19 / 17-\stackrel{\text { a.m. }}{7: 55}$ & 12 hours & Cotton & 8.1 \\
\hline c & 36 & Alcoholic & $6 / 19 / 17-7: 53$ & $6 / 19 / 17-7: 55$ & 12 hours & $\begin{array}{l}\text { Paraffined; } 1 \text { c.c. } \\
\text { of space left } \\
\text { on top of fluid }\end{array}$ & $7.5-7.6$ \\
\hline
\end{tabular}


shown in Table IX. To show further that ammonia, even if absorbed from the air, is a negligible factor, I made the following experiment: A fluid was divided into two portions, one of which was exposed to ammonia-free air in a desiccator, and the other left at the ordinary laboratory temperature. After thirty minutes I examined the two fluids for their H-ion concentration and found it to be the same in both cases, showing that the usual decrease in the H-ion concentration of a fluid is not due to absorption of ammonia from the air.

When we compare $\mathrm{H}$-ion concentration of normal cerebrospinal fluid with that of the blood, we find that they are both the same. The H-ion concentration of the blood also ranges between a $P_{H}$ of $7.4-7.6$ immediately after being removed from the body.

\section{Alkaline Reserve}

I determined the alkaline reserve on the amount of $\mathrm{CO}_{2}$ present in the cerebrospinal fluid as hicarbonate, by means of the Van Slyke alkaline reserve apparatus. Table XVI shows the alkaline reserve in nommeningitic fluid:

TABLE XVI

Alkaline Reserve of Nonmeningitic Cerebrospinal Fluid

\begin{tabular}{ccc}
\hline No. DIAinosis & ALKALINE RLSERVE \\
\hline 1. Tabes & 56.5 \\
2. Poliomyelitis & 45.7 \\
3. Uremic eoma & 52.0 \\
4. Meningism & 47.5 \\
5. Chorea & 68.0 \\
6. Demential precox & 58.75 \\
7. Psychosis & 55.72 \\
8. Cerebrospinal lues & 55.72 \\
9. Psychosis & 57.54 \\
\hline
\end{tabular}

The above shows that the alkaline reserve of nommeningitic cerebrospinal fluid varies between 45.7 and 63.0 , the average being between 52 and $57 \%$ of $\mathrm{CO}$. found by the cerebrospinal fhid at $0^{\circ}$ temperature, at 760 barometric pressure, which is about the same as the alkaline reserve of blood. 


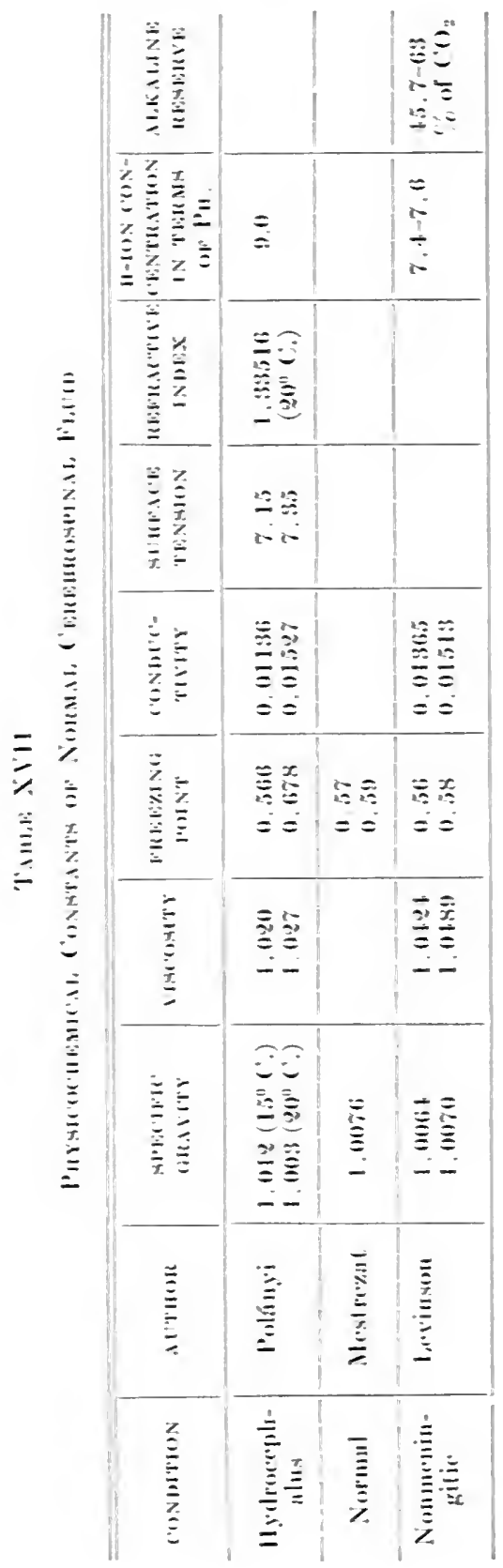




\section{BIOCHEMICAL PROPERTIES}

The data on the biochemical properties of normal cerebrospinal fluid are conflicting in nature. Up to date most of the biochemical findings reported on have been negative, but it is possible that with more accurate methods positive biochemical properties may be found.

\section{Amylolytic Power}

Toison and Lenoble found that the cerebrospinal fluid of hydrocephalics possesses amylolytic power. Cavazzani reports the same. Galletta, however, says that he found this to be true in only two out of eleven cases examined. Mestrezat found no amylolytic power in the normal cerebrospinal fluid or very slight traces of it.

\section{Proteolytic Power}

Link and Pollack report finding a peptolytic enzyme in normal cerebrospinal fluid. In three cases of hydrocephalus and one case of spina bifida examined for the presence of pepsin or trypsin Halliburton found no trace of either. Miller found no proteolytic enzyme or antienzyme in normal cerebrospinal fluid.

Galletta found a fat-splitting enzyme in three of seven cases. Clere found none.

\section{Glycolytic Ferment}

Cavazzani found glycolytic ferment in the cerebrospinal fluid. However, neither Panzar, Lewandowsky, nor Mott conld find the presence of any glycolytic ferment.

\section{Fibrin Ferment}

Normal fluid contains no fibrin ferment.

\section{Alexin}

Normal fluid contains no alexin. 


\section{Hemolysin}

Normally no hemolysin is found in the fluid.

\section{Toxicity}

Normal fluid is not toxic, compared to pathologic fluid which is toxic.

\section{Bactericidal Action}

The question as to whether normal fluid has a bactericidal action has not yet been settled.

\section{CYTOLOGY}

The study of the cell content and of the cell elements of the cerebrospinal fluid was inangurated in France by Ravant, Sicard, Nagoette and Widal in 1901, and has since been recognized as a very important phase of the study of the cerebrospinal fluid.

The exact number of cells in normal cerebrospinal fluid is a matter on which authorities who have worked with the fluid do not agree. Fuchs and Rosenthal found 0 to 2 cells per c.mm. in normal fluid, Rehm found 1 to 5 and even 6 to 9 , and Gennerich found 8 cells in the fluid of one healthy person. There are others who give the number as $\mathbf{5}$ to 20 per c.mm. The reason for the wide discrepancy is the fact that different investigators have employed different methods in determining the number of cells. There are some who count the cells in the centrifuged fhuid, using a certain amount of fluid in a graduated centrifuge tube and taking one drop of the sediment on a slide (the so-called French method), and others who count the cells in counting chambers. It is easy to see how these two methords will give entirely different results, the difference being at times as high as 50 or 60 per cent. Even those who count the cells in a counting chamber, get variations in their results due to the type of chamber they use. The Fuchs-Rosenthal 
chamber, for instance, gives a smaller percentage of error than the ordinary lencocyte counter. The greatest source of errors responsible for the discrepancy of findings by various authors however, is the admixture of blood in the cerebrospinal fluid, for no matter how clear the fluid may look there may be some blood cells obtained by the passage of the needle through the tissue, which would in turn result in enormous errors, when figured out as their number per c.mm. In addition to the above factors, the amount of cerebrospinal fluid used for comting and the use of a stain may account for the difference in the reports of the various authors.

I found the number of cells in normal fluid to be between 4 and 6 per c.mm. I have, therefore, adopted this number as an arbitrary standard, anything above 6 cells per c.mm. being suspicious, and anything above 10 cells per c.mm. being indicative of some pathologic condition of the central nervous system. I, of course, make certain that the cerebrospinal fluid contains no blood to begin with.

Fischer claims that the result obtained in the cell count of fluid obtained by lumbar puncture is not indicative of the cell count in the cerebrospinal fluid contained in the ventricle of the brain. 'This, however, has been found by Nomne not to be true. The cell content in the fluid of the lumbar region, and that of the ventricle are found to run parallel to each other. I have found that the cell content in the different portions of the cerebrospinal fluid does differ, the first tube containing more cells than the subsequent fluid. I believe that this may be due to a contamination of blood cells in the first portion of the fluid. In this comnection, it is interesting to point ont that one author advises shaking the patient from side to side before doing a lumbar puncture, in order to stir up the cells and distribute them evenly which, of course, is very absurd. 


\section{Type of Cell}

Normally, no red blood cells are found in the fluid, the cells in the fluid always being leucocytes. The normal type of lencocyte in cerebrospinal fluid is the small lymphocyte, which is the size of a red blood cell or slightly smaller or larger than the red blood cell. The nucleus of the lymphocytes of normal cerebrospinal fluid is round or slightly oval. It is seldom irregular. The nucleus fills up the largest part of the cell leaving a very small cell body. No granules can be detected in the cells, as a rule. The nucleus stains intensively with methyl-violet, while the cell body does not.

Large lymphocytes do occur in normal fluid but not very frequently. It has been observed that there very seldom exists a combination of large and small lymphocytes in the same specimen of fluid that gives no other pathologic findings. Large lymphocytes, however, always should make one think of some diseased condition of the central nervous system.

The origin of the cells in the cerebrospinal fluid is not fully determined. The cells in normal fluid would seem to be of hematogenous origin as they are small lymphocytes with occasional large forms which are also found in the blood. On the other hand, the cell forms in the fluid of pathologic conditions are often very different from those in the blood and this suggests some other source for the cells. The fibroblasts, for instance, would point to a histogenic origin of the cells. It is possible, of course, that the cells do originate in the blood and during their transmission into the cerebrospinal fluid or while in the cerebrospinal fluid may change forms. Szecsi suggested that some cells originate in the blood, while fibroblasts and other such elements have a histogenic origin. I believe that under normal conditions the cells in the cerebrospinal fluid originate in the blood and have the same characteristics as the cells in other parts of the body. 


\section{Bibliography}

Risgaard: Untersuelıugen über die Wiweiss und Stickstoffrerhältnisse der Cerebrospinalflüssigkeit sowie iiber die Wasserstoffionen-Konzentration, Bioehem. Ztsehr., 1914, 1viii, 1.

Cavazzani: Über die Cerebrospinalflüssigkeit, Centrallbl. f. Physiol., 1892, xiv, $6,393$.

Weiteres über die Cerebrospinalflüssigkeit, Centralbl. f. Physiol., No. 6, 145.

Concetti: Chemische Untersuchungen über die Hydroeephalusflüssigkeit von Kindern, Areh. f. Kinderh., 1898, xxiv, 161.

Commal: A Study of the Cerebrospinal Fluid in the Infeetive Diseases with Special Reference to Cerebrospinal Fever, Quart. Jour. Med., 1910, jii, 152.

Coriat: Cerebrospinal Fluid in Hydrocephalus, An. Jour. Physiol., 1903, $\mathrm{x}, 111$.

Cottin and Saloz: La Mesure de la pression du liquide cephalo-raehidien, Rev, de Med., 1916, xxxv, 511.

Cullen and Fillis: 'Tne Urea Content of Human Spinal Fluid and Mlood, Jour. Biol. Chem., 1915, xx, 511.

Felton, Hussey, and Bayne-Jones: The Reaction of the Cerebrospinal Fluid, Areh. Int. Med., 1917, xix, 1085.

11ildebrandt: Some Application of the Hydrogen Electrode in Analysis, Researeh and 'leachng, Jour. Am. Chem. Soc, 1913, xxxy, $\$ 47$.

Henderson: The Theory of Nentrality Regulation in the Animal Organism, Am. Jour. Physiol., 1908, xxi, 427.

Hoppe: Ueler die chemische Zusammensetzung der Cerebrospinalflüssigkeit, Virehows Areh., 1859, xvi, 391.

Hurwitz and Tranter: On the Reaction of the Cerebrospinal Fluid, Areh. Int. Med., 1916, xrii, 828.

Kafka: Die Cerebrospinalllüssigkeit, Ztsehr. für die gesammte Neurologie und Psychiatrie, Referrate, 19, vi, Part 4, 321.

Landau and Halpern: Jeiträge zur Cnemic der Cerebrospinalflïssigkeit, Bioehem. Ztsch., 1905, ix, 72.

Lery, Rowntree, Marriott: A Simple Method for Determining Variations in the Hydrogen-ion Concentration of the Blood, Areh. Int. Med., 1915, xvi, 389.

Levinson: The Hydrogen-ion Concentration of Cerehrospina! Fluid, Jour. Infeet. Dis., 1917, xxi, 556.

Leopold and Bernhard: Studies in the Chemistry of the Spinal Fluid of Children, Am. Jour. Dis. Child., 1917, xiii, 34.

Michaelis, L.: Die Wasserstoffionenkonzentration, Berlin, 1914.

Mott: The Cerebrospinal Fluid, Lancet, 1910, ii, 1.

Palmer, W. W. and Henderson, L. J.: Chemical Studies in Aeid Base Equilibrium and the Nature of Acilosis, Areh. Int. Med., 1913, xii, 153.

Pfeiffer, Kober, Field: Nephelometrie Study of the Proteins of Cerebrospinal Fluids, Proe. Soe. Exper. Biol. and Med., 1915, xii, 7.

Polányi: Beiträge zur Chenie der Hydrocephalusflüssigkeit, Bioehem. Ztsehr., 1911, xxxiv, 205.

Satta, Gastuldi: Antityptie Power of Cerebrospinal Fluid, Biochem. Et. Therap. Sper. 2, 49-56, Ztsehr. Immunit. (Ref.) 3, 814 .

Sehultze: Krankleiten der IFirnhaute, Nothnagel, ix, 1894.

Soltmann: T'he Chemistry of Cerebrospinal Fluid, Jour. Am. Med. Assn., 1903, 1. 1569.

Sörenson: Ueher die Messung und Bedeutung der Wisserstoffionenkonzentration bei hologischen Prozessen, Ergebnisse der Physiologie, 1912, xii, 39:\%. 
Toison and Lenoble: Note sur la structure et sur la composition du liquide cephalo-rachidien chez l'homme, Compt. rend. Soc. de biol., 1S91, xliii, $373-379$.

Turner: Examination of the Cerebrospinal Fluid as au Aid to Diagnosis in Certain Cases of Insanity, Jour. Ment. Sc., 1910, lvi, 485.

Van Slyke: A Method for Determination of Carbon Dioxide and Carbonates in Solution, Jour. Biol. Chem., 1917, xxx, 347.

Weston: The Reaction of the Cerebrospinal Fluid in the Psychoses, Jour. Med. Research, 1917, xxxr, 367.

Zlarek: Ein Beitrag zur Kenntniss der Cerebrospinalfliissigkeit, Ztschr. f. physiol. Chem., 1902, xxxv, 202. 


\section{CHAPTER V}

\section{PATHOLOGIC CEREBROSPINAL FLUID}

Cerebrospinal fluid reacts to all processes that affect the central nervous system. The changes taking place in the fluid under pathologic conditions are due to two causes: systemic and meningitic. The systemic changes are due to metabolic disturbances in the body snch as nephritis or diabetes. The meningitic changes are due to affections of the meninges. These may be divided into (1) simple irritation of the meninges or of the brain tissue; (2) infection of the meninges. Irritation of the meninges may be produced by mechanical disturbances in the cranial cavity, or by the action of metabolic or infectious toxins. The latter condition is termed serous meningitis by some, and meningism by others, the latter term being used to describe all conditions wherein the meninges are irritated by some toxic substance which increases the amount and pressure of the cerebrospinal fluid without changing the chemical composition of the fluid or affecting its sterility. This is the condition that often exists in pneumonia, influenza, and otitis media. Simple irritative changes produce only physical alterations in the fluid or at most only slight physicochemical changes. Changes produced by the entrance of bacteria into the fluid, on the contrary, take on a varied character and may be physical, chemical, cytologic, and bacteriologic. These changes may appear singly or in various combinations at one and the same time. Some anthors voice the opinion that the irritative and infectious changes differ in degree only, and not in character. I believe, however, that although there are changes common to both conditions, those in infections 
are different in type from those of simple irritation. Furthermore, the reaction is specific for each type of infection.

Just how bacteria may enter the cerebrospinal fluid is still a matter of controversy. There are two ways in which they can make their entrance: one is through the circulation and the other is by direct continuity from the nose or from the ears. For a long time it was thought that the attack of the meninges in epidemic meningitis or in poliomyelitis was by way of the lymphatics of the nasal mucous membrane, the bacteria passing through the cribriform plate of the ethmoid directly into the meninges. However, the fact that the meningococeus in many cases may be cultivated directly from the blood in the early stages of meningitis, and that arthritis and iridochoroiditis often complicate meningitis would make one believe that the meningeal infection is most frequently hematogenous. The recent work of Austrian on experimental meningitis is also suggestive of the septicemic nature of meningococcic invasion.

In tubereulous meningitis the infection hardly ever reaches the meninges directly from the nose. It is usually part of a general miliary tuberculosis of which the meningitis is a terminal process. From the work of Albrecht and Ghon, we know that the primary process of tuberculosis usually takes place in the lung, and gives rise to an enlargement of the hilus glands, which in time either becomes retrogressive with calcification, or goes on to a general miliary tuberculosis. According to this explanation, what happens in tuberenlous meningitis, then, is first a tuberculous infection in the lung tissue proper; second, an infection of the hilus glands; and third, an invasion of the meninges by way of the blood. It takes some time before the protective wall of the meninges is broken through by the tubercle bacilli, but they finally break through and infect the meninges. That tuberculous meningitis is a part of 
a miliary tuberculosis is seen on autopsy, miliary tubercles being found in the lungs, liver, and spleen in all cases.

The pnemococi act much like the tubercle bacilli and meningococci in their relation to meningitis. Not every pneumonia, it is true, produces a pnemmococcus meningitis but almost every pnemmococcus meningitis is the result of a pneumococcus septicemia. Some observers claim that they have found pneumococci in the cerebrospinal fluid in uncomplicated pneumonia, but this seems very unlikely. There is no apparent reason why pneumococci in the fluid should produce meningitis in one instance and not in another. It is probably safe to assume that if no meningitis is produced there are no bacteria in the cerebrospinal fluid. The nervous system is the master system of the body, and Nature has provided it with protection by surrounding it with cerebrospinal fluid and with three layers of meninges, one of which, the dura, is especially heavy and firm. In addition, Nature also protects the meninges with the heavy walls of the skull and spine and in spite of the fact that the nervous system is a delicate system, and that the cerebrospinal fluid is not microbicidal it is not easy for bacteria to gain access to either.

In certain cases the meningococci and other bacteria find their way into the cerehrospinal fluid through the cribriform plates of the ethmoid. The nasal mucous membrane may harbor pnemmococei and streptococci, meningococei and influenza bacilli, and it is conceivable that when the system is in a low state of resistance, the bacteria may enter the meninges directly. The cerebrospinal fluid in these cases, instead of being a means of protection for the central nervous system, serves as a good medium for the dissemination of the bacteria.

Still another route for the entrance of bacteria into the cerebrospinal fluid is the ear. In advanced cases of otitis media or mastoiditis, the bacteria may enter the brain substance, in which case they produce a brain abscess or 
the meninges, in which case they produce a meningitis. This happens most frequently in infections with the pneumococcus, and with the streptococcus hemolyticus.

Less frequently bacteria make their way into the cerebrospinal fluid through wounds of the skull and spine, especially through fractures of the skull.

Whichever way the bacteria enter the cerebrospinal fluid, once there, they produce changes in the meninges or brain and give rise to many alterations in the fluid. Some of the changes are common to all pathologic processes in the meninges or brain, whereas others are specific to certain bacteria or toxic substances.

\section{Increase in Amount of Fluid}

It is the rule that whenever there is irritation in some serous cavity, the fluid normally present is increased in amount. This is true of the pleural eavity, the peritoneum, pericardium, and also of the meninges. Any irritation of the meninges, therefore, increases the amount of cerebrospinal fluid, the increase in some cases being only moderate, in others very great. Is every case of increased cerebrospinal fluid to be termed a serous meningitis as Quincke proposed? It would seem less confusing to use E. Dupré's term of meningism for all cases where the fluid shows only physical changes and reserve the term meningitis for all processes producing chemical, cytologic and bacteriologic changes. The name, however, makes little difference. The important fact is that there are two classes of irritation of the meninges. It should be noted that the more acute the irritation, the greater the amount of fluid accumulating in the ventricle and in the subarachnoid spaces.

\section{Pressure}

With the increase in the amount of fluid in the subarachnoid there is naturally an increase in the pressure of the fluid, so that we very seldom have a pathologic process of 
the meninges without a corresponding inerease of the pressure of the fluid. Here also the character of the process and the degree of its acuteness determine the increase in pressure.

\section{Foam}

I found that all pathologic fluids produce a foam on shaking. When a test tube is filled one-third to one-half its size with fluid, and is shaken for two or three minutes, a heavy foam one to two inches in thickness forms, persisting for half an hour or longer. When normal fluid is shaken in a test tube only a thin foam forms, disappearing in a few minutes. The foam is present in all pathologic fluids, but it is of greater size and duration in acute infections of the meninges. Recently Zingher described the formation of a heary foam in poliomyelitis which corroborates my observations. It seems but natural to think that the foam production is due to the $\mathrm{CO}_{2}$ in the fluid. Close observation, however, does not bear this out. I found repeatedly that a foam formed just as readily in fluid in which all the $\mathrm{CO}_{2}$ had been driven off, if the fluid was pathologic. The foam, therefore, is best explained by the increased amount of protein in the fluid.

\section{Cells}

Any infection of the meninges gives rise to an increased number of cells in the cerebrospinal fluid. The cells in disease are derived from the congested blood vessels of the meninges, the number of the cells varying with the causative organism and with the acuteness of the process. The character of the cells also differs with the type of the inflammation. In acute inflammations the polynuclear cells prevail and in subacute or in chronic inflammations the lymphocytes are the rule. In general paresis, according to Alzheimer, plasma cells predominate.

Does an increase in the cells of the cerebrospinal fluid mean a corresponding increase in the white cells of the 
blood? This interesting question has been studied by many authors who found that although the leucocytes in the blood are usually increased in meningitis, the lencocytes in the blood and those in the fluid do not necessarily rum parallel. There are cases of meningitis in which several thousand cells per c.mm. have been found in the cerebrospinal fluid, but only six to eight thousand leucocytes per eubic millimeter in the blood. There are other eases on the contrary where there is a high leucocytosis of the blood and only a slight increase in the cells of the cerebrospinal fluid.

In addition to these changes common to all pathologic fluids, there are changes peculiar to special types of disease. The changes are manifold, physical, chemical, physicochemical, and bacteriologic. I shall discuss here the mechanism of the various changes and leave the description of the methods for the next chapter.

\section{Pellicle}

In addition to the physical changes which make their appearance in the cerebrospinal fluid under all pathologic conditions of the meninges, such as an increase in the amount, in the pressure, and the foam of the fluid, there is one change which takes place in the cerebrospinal fluid that is fairly characteristic for various diseases. This is the formation of a pellicle.

In most acute diseases of the meninges a pellicle or a net of fibrin and blood cells forms in the fluid on standing. The time it takes a pellicle to form varies with the character of the disease. In suppurative meningitis, the pellicle forms in a rery short time. In tuberculous meningitis, it takes from twelve to twenty-four hours for the pellicle to form, althongh $I$ have seen it form in as short a time as one hour. Some authors have described a pellicle formation in polionyelitis and in lues of the central nervous system. I have observed a pellicle in polionyelitis only very rarely. I 
have, however, observed a certain sediment in some cases of tabes dorsalis and in certain cases of cerebrospinal lues. The sediment formed was flocculent in type, resembling the floceuli formed by the Noguchi test, or after the addition of sodium hydrate to the fluid of tuberculous meningitis.

The pellicle consists of a separation of the heavier elements of the cerebrospinal fluid, so that microscopically

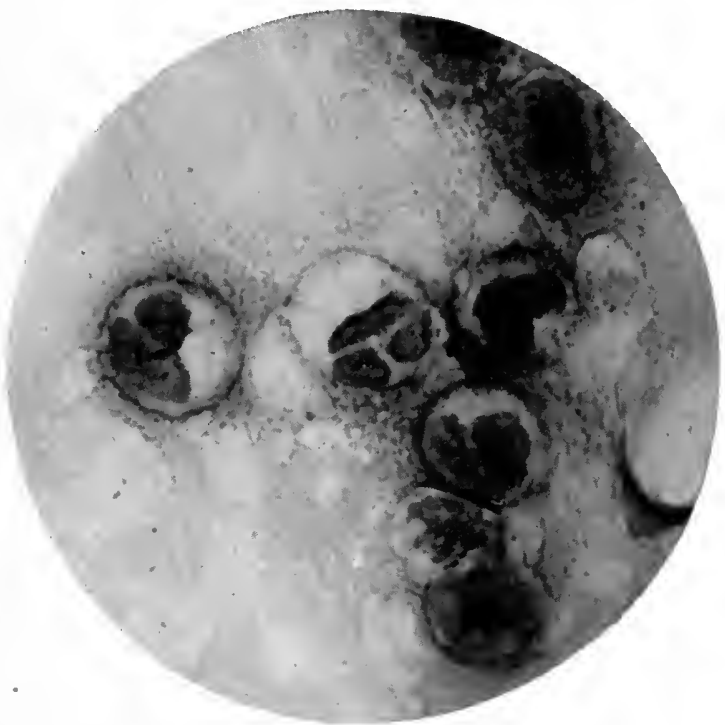

Fig. 22.-Photomicrograph of stained pellicle from cerebrospinal fluid of a pneumococcus meningitis.

one can see in the pellicle many leucocytes on a fibrinous background. (Fig. 22.)

The formation of a pellicle depends on three factors: (1) fibrin; (2) fibrin ferment; (3) blood cells. Of these three factors the most important is the fibrin, although the other two also play an important role. The addition of blood serum to the cerebrospinal fluid accelerates the formation of a pellicle, but it is generally inadrisable to add blood serum, as it interferes with chemical tests.

The pellicle not only indicates the existence of a pathologic condition, but also, I believe, serves to show the phys- 
ical changes produced in various fluids. Fig. 23 illustrates the various forms of pellicle in various diseases as observed early before autolysis takes place.

\section{Crystallization}

Another pliysical phenomenon which takes place in cerebrospinal fluid on standing, is the formation of crystals,

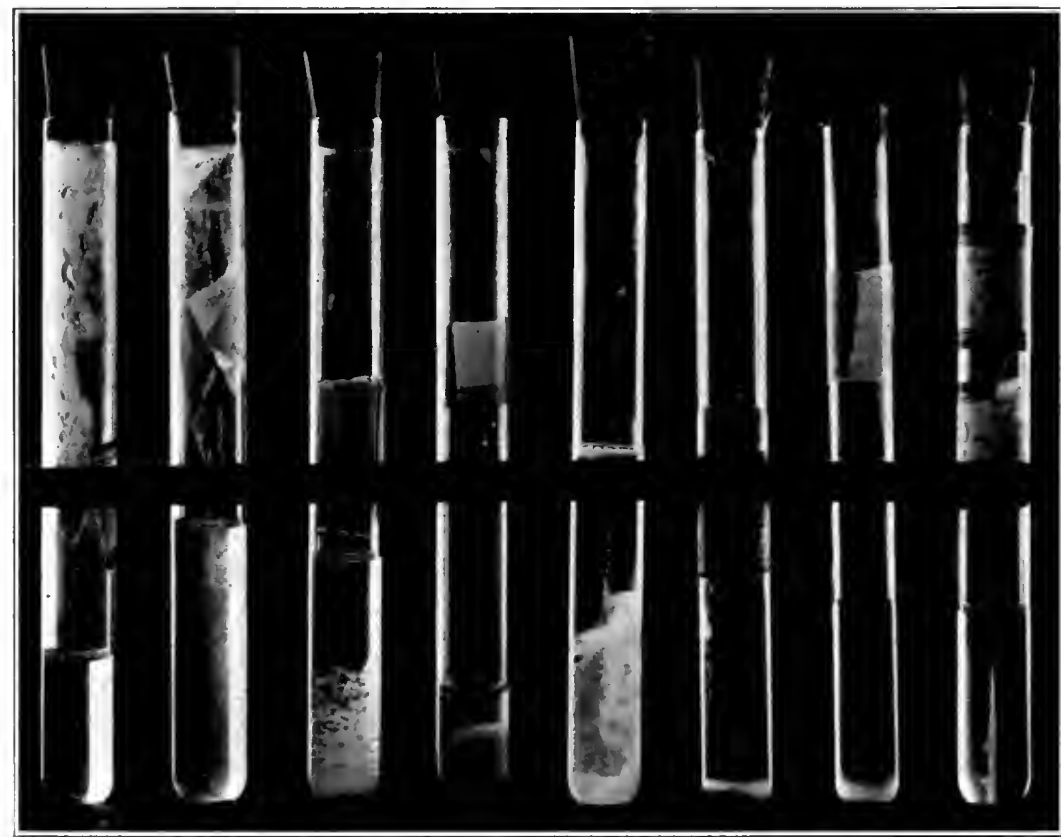

A. $\quad B$.

C.

$D$.

E.

$F$.

$G$.

$H$.

Fig. 23.-Pellicle formation in meningitis.

A. Normal. B. Meningococcus meningitis, fairly early. C. Meningococcus meningitis, advanced (sulphur-like granules). D. Meningococcus meningitis, late in disease. E. Meningococcus meningitis, severe, on road to recovery. $F$. Pneumococcus ineningitis, fatal. G. Pneumococcus meningitis, fatal. $H$. Tuberculous meningitis.

their character depending on the character of the disease. Various authors have called attention to the crystals found in the cerebrospinal fluid. Mott speaks of cloolin crystals in the fluid of patients suffering from disease producing a degeneration of the nervous tissue. Thomson describes 


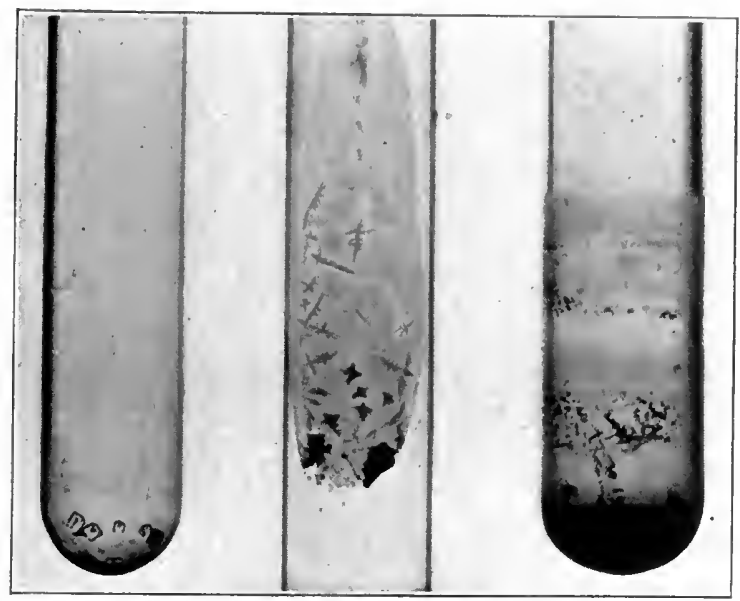

Fig. 24.-Crystals formed in test tube on spontaneous evaporation of cerebrospinal fluid from a case of tuberculous meningitis.

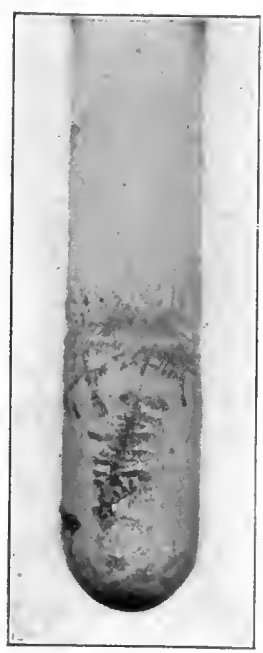

Fig. 25.-Spontaneously evaporated fluid from another case of tubcrculous meningitis.

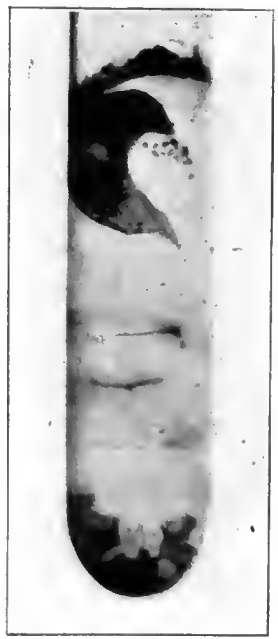

Fig. 26.-Spontaneously evaporated cerebrospinal fluid from a case of meumococcus meningitis.

the presence of elongated, colorless, transparent crystals in septic meningitis. He suggests that the acid radical present in the crystals is most likely phosphoric acid. I 


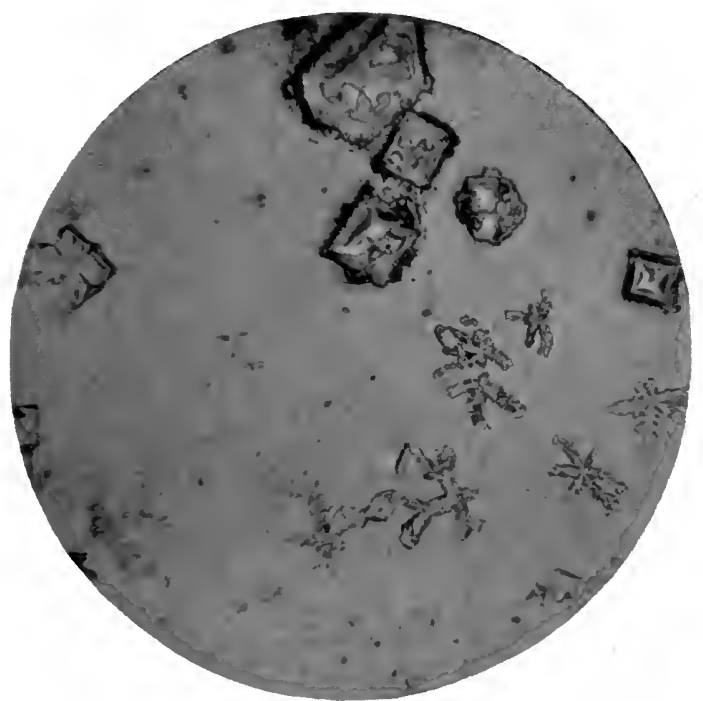

Fig. 27-A.-Crystals from an evaporated fluid in a case of tuberculous meningitis. (76 diameters.)

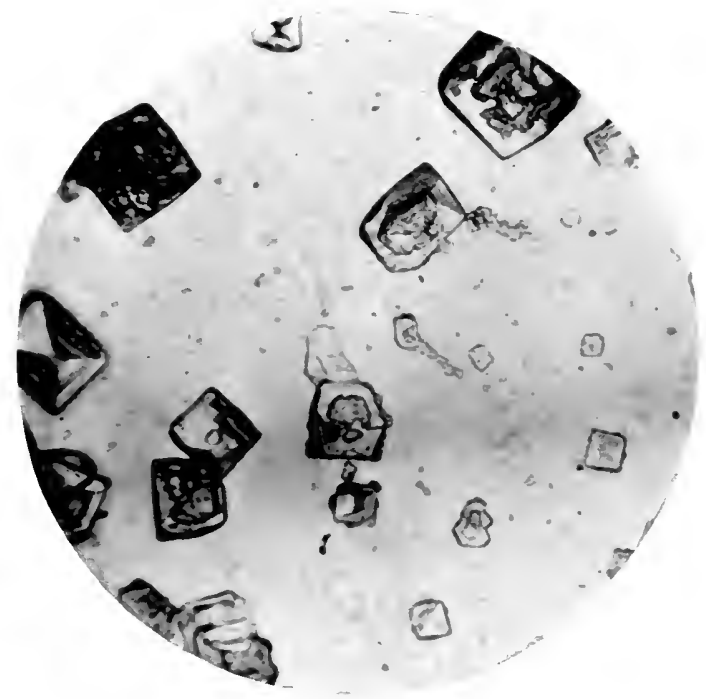

IFig. 27-B.-Crystals from another evaporated fluid of a case of tuberculous meningitis. (76 diancters.) 
made a study of the crystalization process in a great number of pathologic fluids which were allowed to evaporate spontaneously at room temperature, and found that after several months of standing, most pathologic fluids showed the presence of many crystals of various sizes and shapes different from those formed in nommal fluids. Figs. 24, 25, and 26 show the different forms of crystals present in different conditions, the varieties being even more distinct on microscopic examination. (Figs. 27 and 28.)

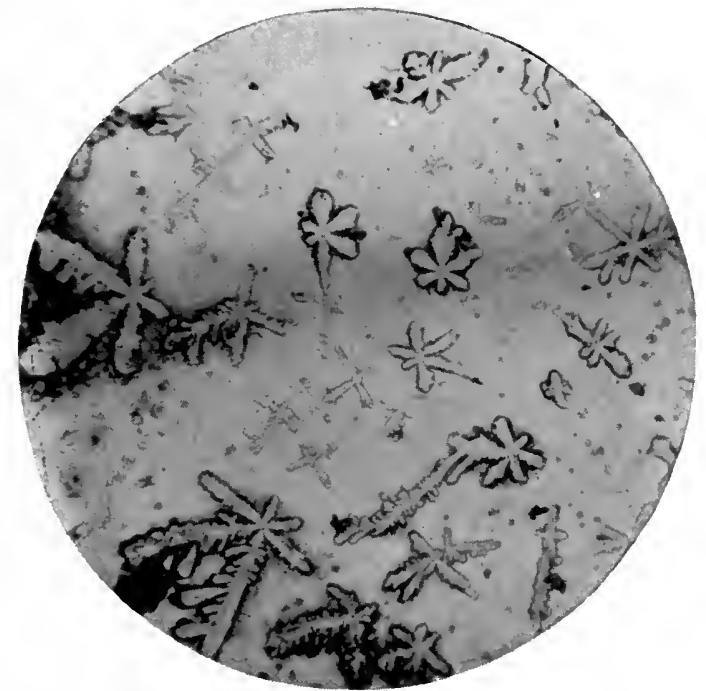

Fig. 28.-Crystals from an evaporated fluid of a case of pneumococcus meningitis. (76 diameters.)

\section{Permanganate or Organic Index}

Mayerhofer was able to show by means of the Kubl Thiemich permanganate method that there is an increase in the organic substance in cerebrospinal fluid in all meningitides. This increase, he found, could be measured by the amount of permanganate necessary to oxidize the organic substance. Mayerhofer's observations led him to the following conclusions: 
TABLE XVIII

Organic Index ix Cerebrospixal Fluid ix Variocs Forms of Mexingitis

\begin{tabular}{|c|c|c|c|c|c|c|}
\hline \multirow{2}{*}{ NAME } & \multirow{2}{*}{ DIAGXOSIS } & \multicolumn{5}{|c|}{ PERMANGANATE IXDEX } \\
\hline & & TUBE I & TCBE II & TUBE III & TUBE IV & TUBE V \\
\hline A.M. & Tuberculous meningitis & 3.0 & & 3.0 & & \\
\hline A.M. & $\begin{array}{l}\text { Tuberculous meningitis } \\
\text { (Same case } 4 \text { days later.) }\end{array}$ & $\begin{array}{l}2.9 \\
3.35\end{array}$ & 2.6 & 3.2 & $\begin{array}{c}4.55 \\
(15 \text { c.c. } \\
\text { between })\end{array}$ & \\
\hline J. P. & $\begin{array}{l}\text { Tuberculous meningitis } \\
\text { (Examined } 2 \text { days later) }\end{array}$ & $\begin{array}{l}2.55 \\
\mathcal{2 . 9 5}\end{array}$ & $\begin{array}{l}1.7 \pi \\
1.55\end{array}$ & $\begin{array}{l}1.6 \\
1.75\end{array}$ & & \\
\hline D. II. & $\begin{array}{c}\text { Tuberculous meningitis } \\
\text { (Examined } 3 \text { days later) }\end{array}$ & $\begin{array}{l}3.1 \\
3.9\end{array}$ & 1.8 & 3.0 & 2.7 & 2.7 \\
\hline M. H. & Tuberculous meningitis & 2.1 & & & 1.8 & \\
\hline D. $\mathrm{K}$. & Tuberculous meningitis & 2.6 & $\mathcal{2} .2$ & & & \\
\hline E.S. & Epidemic meningitis & 7.9 & & & & \\
\hline E. C. & Epidemic meningitis & 5.6 & & & & \\
\hline D. S. & Epidemic meningitis & 2.0 & & & & \\
\hline O. C. & $\begin{array}{c}\text { Epidemic meningitis } \\
(12 \text { hours after serum } \\
\text { injection })\end{array}$ & $\begin{array}{l}9.2 \\
7.3\end{array}$ & $\begin{array}{l}9.3 \\
8.7\end{array}$ & & & \\
\hline M. E. & Influenza meningitis & 2.6 & & & & \\
\hline E. M. & $\begin{array}{l}\text { Pneumococcus meningitis } \\
\text { (Examined.7 days later) }\end{array}$ & $\begin{array}{l}3.3 \\
4.6\end{array}$ & $\begin{array}{l}4.3 \\
4.3\end{array}$ & $\begin{array}{l}3.0 \\
4.6\end{array}$ & & \\
\hline H. N. & P'neumococcus meningitis & 4.7 & & 4.7 & +7 & \\
\hline
\end{tabular}

(1) That the reduction index of normal cerebrospinal fluid is low. Different portions of the same fluid give either the same reduction index or a different one, the tendency being toward a higher index in each subsequent portion.

(2) That the reduction index of meningitis is higher than that of normal cerebrospinal fluid (2 and up). Un- 
like normal fluid, the index becomes lower with each subsequent portion of the fluid.

(3) That the reduction index of cerebrospinal fluid in epidemic meningitis drops to one-half its original pathologic rate after an injection of meningococcic serum.

My work on the permanganate index gave similar results. I found that fluid of all forms of meningitis gives a higher organic index than normal fluid and that the fluid of suppurative meningitides gives a higher organic index than fluid of tuberculous meningitis. Table XVIIT gives some of the findings with the permanganate index in fluid of various diseases.

\section{Protein}

In normal cerebrospinal fluid the protein content is small and consists mainly of globulin. In pathologic conditions there is both an increase in the amount of the protein and a change in its character, as Table XIX of Nestrezat shows. (Figures expressed in grams per liter).

\section{TABLE XIX}

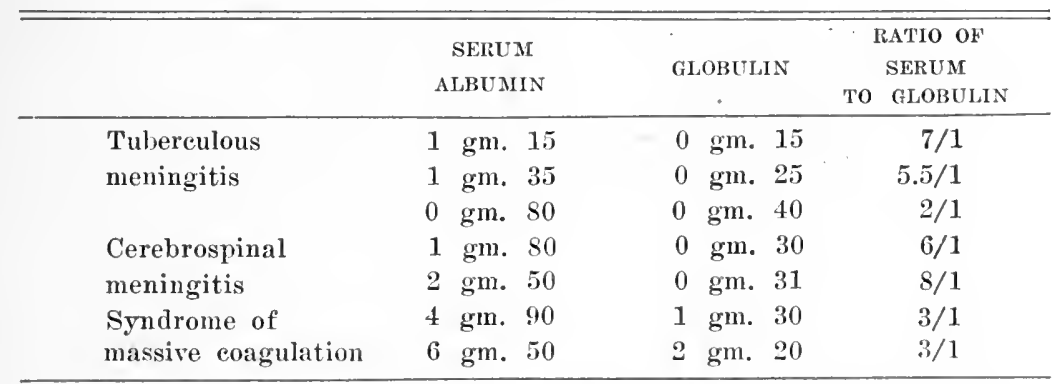

\section{Precipitation}

'The action of the precipitants on cerebrospinal fluid in various diseases furnishes another evidence of the varying character of the protein in different diseases. Tashiro and I found that in certain pathologic conditions a character- 
istic ratio may be obtained between the precipitate formed by sulphosalicylic acid and that formed by mercuric chloride. We based our comparison on the assumption that different processes respond differently to alkaloidal

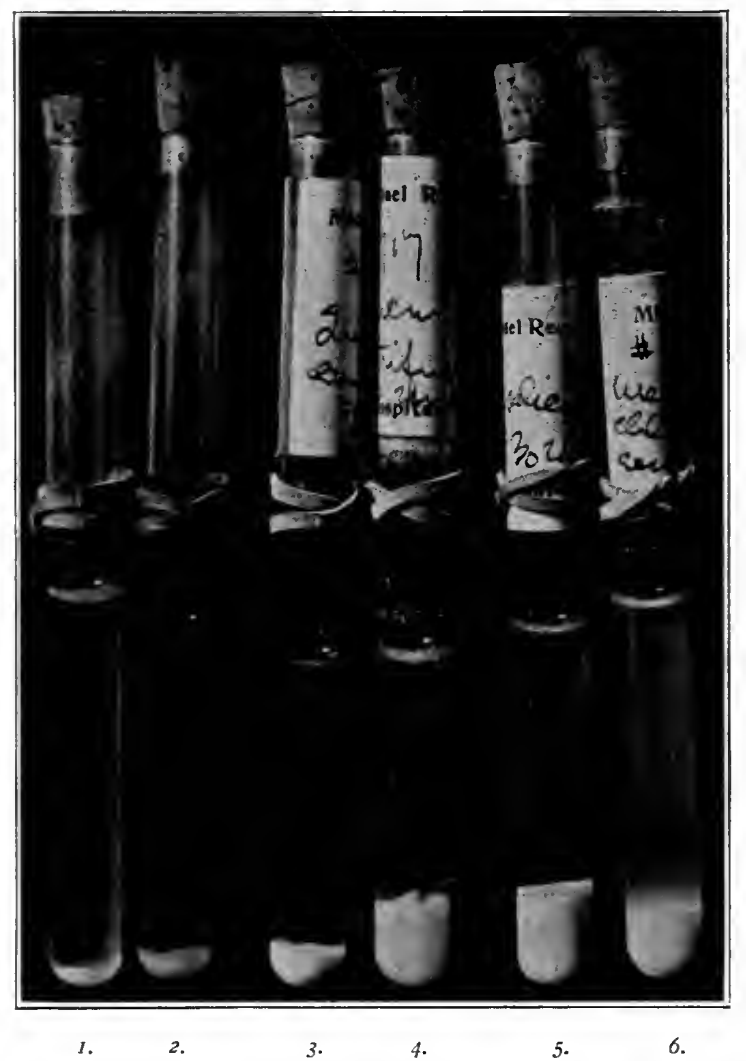

Fig. 29.--Photograph showing the typical ratio of precipitates by the two precipitants.

I. 1 c.c. of nonmeningitic fluid plus 1 c.c. of 3 per cent sulphosalicylic acid.

2. 1 c.c. of nonmeningitic fiuid plus 1 c.c. of 1 per cent $\mathrm{HgCl}_{\mathrm{g}}$.

3. 1 c.c. of fluid from epidemic meningitis plus 1 c.c. of sulphosalicylic acid.

4. 1 c.c. of fluid from epidemic meningitis plus 1 c.c. of $\mathrm{HgCl}_{2}$.

5. 1 c.c. of fluid from tuberculous meningitis plus 1 c.c. of sulphosalicylic acid.

6. 1 c.c. of fluid from tuberculous meningitis plus 1 c.c. of $\mathbf{H g C l}_{\mathbf{g}}$.

precipitants, such as sulphosalicylic acid and metallic precipitants, such as mercuric chloride (Tables XX, XXI, and XXII, Fig. 29). 


\section{TABLE XX}

Comparison of Amount of Sediment from tue Metaldic and Alkaloidal Precipitation witim Nonmeningitic Fluids

\begin{tabular}{|c|c|c|c|}
\hline \multirow[b]{2}{*}{ NUMBER } & \multirow[b]{2}{*}{ DIAGNOSIS } & \multicolumn{2}{|c|}{$\begin{array}{l}\text { MEASUREMENTS OF THE DEPTH OF } \\
\text { SEDIMENT IN MM. AFTER } 24 \text { HOURS }\end{array}$} \\
\hline & & $\mathrm{HgCl}_{2}$ & Sulphosalicylic Acid \\
\hline 1 & Psychosis & 3 & 2 \\
\hline 2 & Tic & 4 & 3 \\
\hline 3 & General paresis & $41 / 2$ & $q$ \\
\hline 4 & Delirium tremens & 3 & 1 \\
\hline 5 & General paresis & $31 / 2$ & 2 \\
\hline 6 & Psychosis & 3 & $\mathcal{Q}$ \\
\hline 7 & General paresis & $3 \frac{1}{2}$ & 2 \\
\hline 8 & General paresis & 3 & 0 \\
\hline $\mathbf{9}$ & Psyehosis & 4 & 3 \\
\hline 10 & Psychosis & 4 & 0 \\
\hline 11 & Psychosis & 4 & z \\
\hline 12 & Meningism & 3 & $q$ \\
\hline 13 & Dementia precox & 3 & 0 \\
\hline 14 & Alcolıolic & 3 & 2 \\
\hline 15 & Psychosis & 3 & $\mathcal{2}$ \\
\hline 16 & Psychosis & 4 & $\boldsymbol{z}$ \\
\hline 17 & Psychosis & 3 & 1 \\
\hline 18 & Psychosis & $21 / 2$ & 2 \\
\hline 19 & Meningism & 3 & 2 \\
\hline
\end{tabular}

TABLE XXI

Amount of Sediment from tile Metalific and Alealoidal Precipitation from Fluid of Tuberculous Meningitis

\begin{tabular}{|c|c|c|}
\hline \multicolumn{3}{|c|}{$\begin{array}{l}\text { MEASUREMENTS OF TILE DEPTH OF } \\
\text { SEDIMENT IN MM. AFTER } 24 \text { HOURS }\end{array}$} \\
\hline NUMBER & $\mathrm{HgCl}_{2}$ & Sulphosalicylic Acid \\
\hline 1 & 10 & 4 \\
\hline 2 & 15 & 4 \\
\hline 3 & 10 & $31 / 2$ \\
\hline 4 & 11 & 5 \\
\hline 5 & 6 & 3 \\
\hline 6 & 7 & 3 \\
\hline 7 & 9 & 6 \\
\hline 8 & 13 & 5 \\
\hline 9 & 11 & 7 \\
\hline 10 & 10 & 4 \\
\hline 11 & 6 & 3 \\
\hline 12 & 10 & 4 \\
\hline 13 & 20 & 5 \\
\hline
\end{tabular}


TABle XXII

Measurement of Seminest from Metallic and Alkaloidal Precipitation from Fluid in Epidemic Meningitis Before Serum was Given

\begin{tabular}{|c|c|c|c|}
\hline \multirow[t]{2}{*}{ - } & \multicolumn{3}{|c|}{$\begin{array}{l}\text { MEASUREMENTS OF THE DEPTH OF } \\
\text { SEDIMENT IN MM. AFTER } 24 \text { HOURS }\end{array}$} \\
\hline & NUMBER & $\mathrm{HgCl}_{2}$ & Sulphosalicylic Acid \\
\hline & 1 & 1 & 8 \\
\hline & 2 & 2 & 7 \\
\hline & 3 & 1 & 20 \\
\hline & 4 & 1 & 10 \\
\hline & 5 & 7 & 20 \\
\hline
\end{tabular}

These findings which can be utilized for diagnostic purposes speak in favor of my contention that there are specific changes produced by various disease processes which manifest themselves both chemically and physicochemically. Although the fluid in cases of tuberculous meningitis contains less organic substances than the fluid of epidemic meningitis as the table on organic index shows, still the mercuric chloride solution produces a heavier sediment in tuberculous meningitis than it does in epidemic meningitis. Table XXIII shows further that the precipitants in question do not bear any quantitative relation to the amount of protein present in the cerebrospinal fluid. In determining

\section{TABLE XXIII}

\begin{tabular}{|c|c|c|c|c|c|}
\hline CASE & DIAGNOSIS & $\begin{array}{l}\text { APPEAR- } \\
\text { ANCE } \\
\text { OF FLUID }\end{array}$ & $\begin{array}{l}\text { AMIOUNT } \\
\text { OF } \\
\text { PROTEIN }\end{array}$ & $\begin{array}{l}\text { MERCU- } \\
\text { RIC } \\
\text { CHLORIDE } \\
\text { SEDI- } \\
\text { MEN' } \\
\text { After } 24 \\
\text { hours }\end{array}$ & $\begin{array}{l}\text { SULPHO- } \\
\text { SALICYL } \\
\text { IC ACID } \\
\text { SEDI- } \\
\text { MENT } \\
\text { After } 24 \\
\text { hours }\end{array}$ \\
\hline 230 & $\begin{array}{c}\text { Tuberculous } \\
\text { meningitis }\end{array}$ & Clear & $0.1 \%$ & $\overline{20 \mathrm{~mm} .}$ & $\overline{5 \mathrm{~mm}}$. \\
\hline 231 & $\begin{array}{c}\text { Tubereulous } \\
\text { meningitis }\end{array}$ & Clear & $0.1 \%$ & $18 \mathrm{~mm}$. & $7 \mathrm{~mm}$ \\
\hline 232 & $\begin{array}{c}\text { Tubereulous } \\
\text { meningitis }\end{array}$ & Clear & $0.9 \%$ & $14 \mathrm{~mm}$ & $6 \mathrm{~mm}$ \\
\hline 233 & $\begin{array}{l}\text { Epidemie } \\
\text { meningitis }\end{array}$ & Turbid & $0.3 \%$ & $5 \mathrm{~mm}$ & $20 \mathrm{~mm}$. \\
\hline 234 & $\begin{array}{l}\text { Epidemie } \\
\text { meningitis }\end{array}$ & Turbid & $0.25 \%$ & $7 \mathrm{mms}$ & $20 \mathrm{~mm}$. \\
\hline
\end{tabular}


the amount of protein present in the fluid I used the method of Esbach, except that I used half the proportions advised for urine. I also added to the cerebrospinal fluid and the reagent, one drop of a 10 per cent solution of acetic acid. I put the entire solution into a small centrifuge tube which I allowed to stand for 24 hours undisturbed. I did not, however, centrifuge the mixture.

\section{Sugar}

The study of sugar in the cerebrospinal fluid in its relation to certain diseases of the meninges, has occupied an important place in the literature. Kopetzky found an entire absence of sugar in all cases of meningitis. His method of determination was qualitative, however, not quantitative. Connall reported an absence of sugar in all acute infections of the meninges. Schloss observed an absence of sugar in some cases of tuberculous meningitis and a small amount in others. Hopkins found a smaller amount of sugar in the fluid of syphilitics than in any other condition except meningitis. My own work on sugar in pathologic cerebrospinal fluids with Strouse gave no alteration in the fluid of lues which we found to contain a normal amount of sugar and gave an increase of sugar in diabetes, and either an entire absence of sugar in various forms of meningitis, or its presence in small or normal amount. Tables XXIV, XXV and XXVI give some of our results.

TABLE XXIV

Sugar Content in tile Cerebrospinal Fluid qf Lues

\begin{tabular}{ccc}
\hline NAME & WASSERMANN TEST & SUGAR CONTENT \\
\hline P. N. & Strongly positive & $0.104 \%$ \\
M. I. & Strongly positive & 0.104 \\
P. G. & Positive & 0.064 \\
M. I. & Strongly positive & 0.048 \\
J. J. & Positive & 0.070 \\
J. I. & Positive & 0.074 \\
E. M. & Suspicious & 0.080 \\
\hline
\end{tabular}


TABLE XXV

Sugar Content in Cerebrospinal Fluid of Diabetes

\begin{tabular}{cccc}
\hline \multirow{2}{*}{ NAME } & \multicolumn{3}{c}{ SUGAR ConTENT } \\
& Cerebrospinal Fluid & Blood & Urine \\
\hline T. G. & 0.076 & 0.080 & 0.42 \\
D. R. & 0.38 & & \\
M. B. & 0.28 & 0.24 & \\
\hline
\end{tabular}

TABLE XXVI

Sugar Content in the Cerebrospinal Fuuid of Meningitis

\begin{tabular}{l|l|c}
\hline \hline NAME & \multicolumn{1}{|c}{ DIAGNosis } & SUGAR \\
\cline { 2 - 3 } J.P. & Tubereulous meningitis & Absent \\
E. L. & Tuberculous meningitis & $0.08 \%$ \\
A. M. & Tuberculous meningitis & Absent \\
M. E. & Tuberculous meningitis & 0.038 \\
M. L. & Tuberculous meningitis & 0.032 \\
I. W. & Tuberculous meningitis & 0.024 \\
O.C. & Meningococcus meningitis & Absent \\
H.F. & Meningococeus meningitis & 0.024 \\
M. K. & Meningococcus meningitis & 0.028 \\
J.R. & Meningococcus meningitis & Absent \\
M. H. & Meningococeus meningitis & Absent \\
S.N. & Pneumococcus meningitis & Absent \\
E. S. & Pneumococeus meningitis & Absent \\
\hline
\end{tabular}

Among the other chemical constituents that undergo changes in certain diseases, are urea, phosphates, cholin, and cholesterol. In nephritis and uremia the urea has been found to be 3.7 per cent and even as high as 4.5 per cent, compared to 0.003 and 0.090 per cent in normal fluid. Some workers have also observed an increase of urea in the fluid in cases of arteriosclerosis with symptoms pointing to an involvement of the central nervous system. Phosphates were found by Donath to be increased in conditions of rapid nerve degeneration, such as progressive paralysis, tabes dorsalis and tumor of the brain. Mott and Halliburton found cholin in the fluid and also sometimes in the blood in cases of severe nervous lesions, especially in paresis. Donath found cholin in the fluid of epileptics and pareties, the largest amount being present in the latter. Pighini reported the presence of cholesterol in cases of general paralysis, dementia precox, and epi- 
lepsy. It was found to be present in 88 per cent of general paralysis, in 66 per cent of epilepsy, and in 43 per cent of dementia precox.

The chlorides were increased in the cases of nephritis I examined. In the cases of meningitis I examined the chlorides differed with the type of infection as seen from Table XXVII.

\section{TABLE XXVII}

Cillorides in Meningitic Fluid

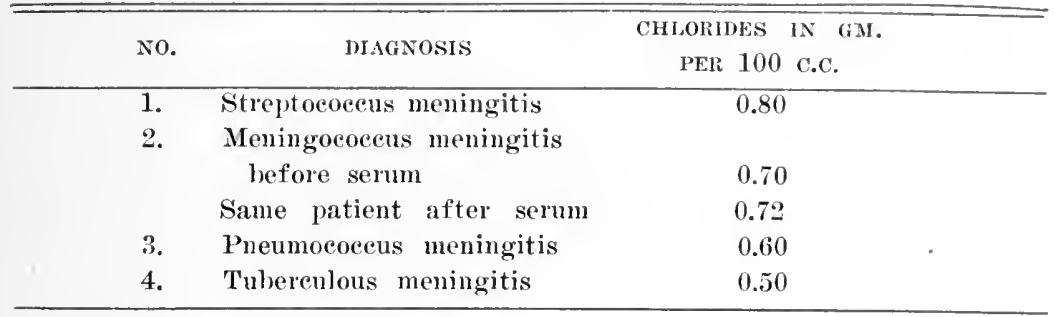

Lactic acid was increased in the cases of suppurative meningitis I examined. It usually took only 5 to 6 drops of cerebrospinal fluid to turn 5 c.c. of Uffelnan's reagent to canary yellow instead of 18 to 20 drops required for nonmeningitic fluid. Acetone was present in some cases after the fluid had been standing for several days. In a case of influenza meningitis there was a deep violet ring such as occurs in urine loaded with acetone. On a number of fluids from meningococcus meningitis the nitroprusside test for acetone gave a deep green ring.

\section{Turbidity}

By using one c.c. of cerebrospinal ftuid in a test tube onethird inch in diameter, and adding to the fluid small portions of decinormal sodium hydrate and decinormal sulphuric acid, I was able not only to detect the presence of a pathologic process, but also to get a clue as to the type of the disease. Normal cerebrospinal fluid shows no turbidity on the addition of either sulphuric acid or of sodium 
hydrate. The fluid of tuberculous meningitis, however, is not affected by sulphuric acid, but is precipitated by a very small amount of sodium hydrate. The fluid of suppurative meningitis, which is turbid to begin with, is cleared up by sodium hydrate and is not affected by sulphuric acid.

\section{PHYSICAL CHEMISTRY}

Among the most important changes that make their appearance in pathologic conditions of the nervous system are those of a physicochemical character. Although not all physicochemical changes are of diagnostic value, they are all of significance in that they bring out specific changes typical of special diseases. What is more, further investigations on the physicochemical changes taking place in pathologic cerebrospinal fhuids give promise of an even wider range of information that can be applied with equal effectiveness to pathologic conditions of other body fluids, such as blood and urine.

Table XXVIII will show some of the variations found in physicochemical constants in various pathologic conditions of the cerebrospinal fluid.

\section{TABLE XXVIII}

Physicociemical Findixgs in Variocs Forms of Meningitis

\begin{tabular}{|c|c|c|c|c|c|c|}
\hline & $\begin{array}{l}\text { SPECIFIC } \\
\text { GRAVITY }\end{array}$ & $\begin{array}{l}\text { VISCOS- } \\
\text { ITY }\end{array}$ & $\begin{array}{l}\text { FRELZING } \\
\text { POINT }\end{array}$ & $\begin{array}{l}\text { CONDEC- } \\
\text { TIVITY }\end{array}$ & $\begin{array}{l}\text { H-ION } \\
\text { CONCLN- } \\
\text { TRATION }\end{array}$ & $\begin{array}{r}\text { ALKALINE } \\
\text { RESERVE }\end{array}$ \\
\hline $\begin{array}{l}\text { Epidemie } \\
\text { meningitis }\end{array}$ & 1.0075 & $\begin{array}{l}1.0434 \\
1.0735\end{array}$ & $\begin{array}{r}-.55^{\circ} \text { to } \\
-.57^{\circ} \mathrm{C} .\end{array}$ & .011629 & $\begin{array}{l}\text { Immed. } \\
\mathrm{P}_{\mathrm{F}} \\
7.3 \\
\text { On Stand- } \\
\text { ing } \\
\mathrm{P}_{\mathrm{H}} \\
\text { Increases } \\
\text { slowly } \\
\text { or may be- } \\
\text { come } \\
\text { more acid }\end{array}$ & $\begin{array}{l}18-38 \% \\
\text { of } \mathrm{CO}^{2} \\
\text { bound } \\
\text { by the } \\
\text { fluid }\end{array}$ \\
\hline $\begin{array}{l}\text { Tubereulons } \\
\text { meningitis }\end{array}$ & $\begin{array}{l}1.00693- \\
1.00626\end{array}$ & 1.0693 & $-.47^{\circ}$ & .013660 & $\begin{array}{c}7.4- \\
7.6 \\
\text { Increases } \\
\text { to } \\
8.1 \& \\
\text { higher }\end{array}$ & $\begin{array}{c}33-\overline{5} 8 \% \\
\text { of } \mathrm{CO}_{2}\end{array}$ \\
\hline
\end{tabular}


A comparison of these figures with those given for nornal fluid (Chapter IV) shows the great variation between the physicochemical constants of pathologic and normal fluids. Other authors have reported even greater differences. Achard, Loeper and Lanbry found the freezing point of fluid from tuberculous meningitis to be $-.44^{\circ}$, and that of epidemic meningitis $-.46^{\circ}$, whereas the freezing point of normal fluid usually varies between $-.56^{\circ}$ and $-.58^{\circ}$.

\section{PROTEIN CHARGES}

It is well known that the electrical charge of a protein depends on the reaction of the medium. In acid solution, proteins become electropositive, and in alkaline solutions they become electronegative, as shown in Table XXIX.

\section{TABLE XXIX}

Showing Cataphoresis of Proteins; Figures 'Taken from Miciafalis

\begin{tabular}{|c|c|c|}
\hline SUBSTANCES & $\mathrm{II}^{+}$ & MOVES TO \\
\hline 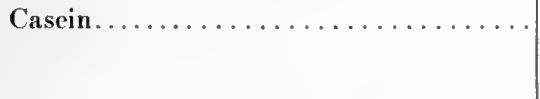 & $\begin{array}{l}4.9 \times 10^{-5} \\
4.1 \times 10^{-5} \\
1.3 \times 10^{-5}\end{array}$ & $\begin{array}{c}\text { Cathode } \\
\text { Stand still } \\
\text { Anode }\end{array}$ \\
\hline Serum Albumin $\ldots \ldots \ldots \ldots \ldots \ldots$ & $\begin{array}{c}1.2 \times 10^{-4}-2.1 \\
\times 10^{-5} \\
2.0 \times 10^{-5}-1.9 \\
\times 1.1 \times 10^{-5} \\
\quad \times 10^{-5}-1.9\end{array}$ & $\begin{array}{c}\text { Cathode } \\
\text { Stand still } \\
\text { Anode }\end{array}$ \\
\hline 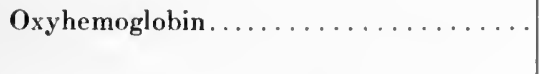 & $\begin{array}{l}2.4 \times 10^{-7} \\
1.2 \times 10^{-7}\end{array}$ & $\begin{array}{l}\text { Cathode } \\
\text { Anode }\end{array}$ \\
\hline Gelatin................ & $\begin{array}{c}1.2 \times 10^{-5}-3.5 \\
\times 10^{-5} \\
3.9 \times 10^{-5}\end{array}$ & $\begin{array}{c}\text { Anode } \\
\text { Stand still } \\
\text { Cathode }\end{array}$ \\
\hline
\end{tabular}

It is thus seen that one way of precipitating protein is to let it combine with some radicle to form an insoluble protein salt. From the standpoint of the electrical charge of the protein such a protein is necessarily either a positive protein radicle forming a protein salt with nega- 
tively charged ions (alkaloidal precipitants), such as tungstic, picric, tannic acid and the like, or a negatively charged protein combining with a positively charged metal (metallic precipitants) such as $\mathrm{Cu}, \mathrm{Ag}, \mathrm{Hg}, \mathrm{Zn}$, and $\mathrm{Pb}$. If these protein salts are sufficiently insoluble, a precipitate will come down.

To ascertain whether the difference in the acidity of the cerebrospinal fluid under various conditions as discussed below is great enough to produce different electrical states of the proteins in the fluids, I have made a series of observa-

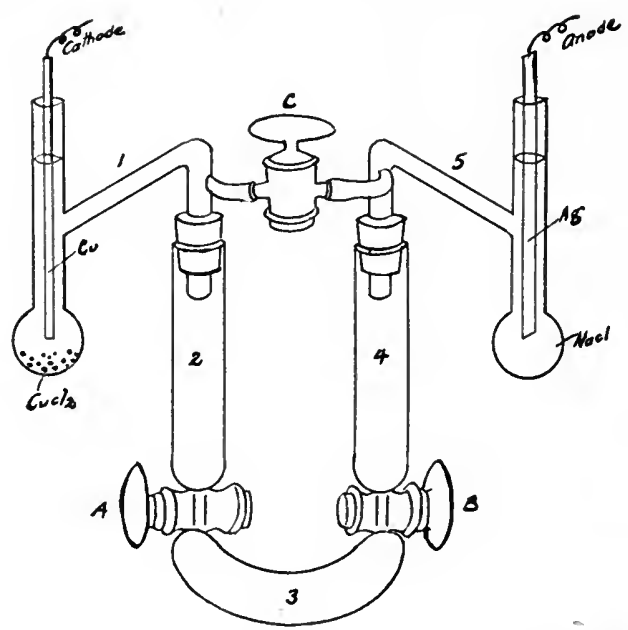

Fig. 30.-Apparatus for cataphoresis of proteins, after Michaelis.

tions. The apparatus used was the one recommended by Michaelis. (Fig. 30.)

The fluids were placed in 3 , care being taken to see that there was no bubble inside the core of the stopcocks. Tubes 2 and 4 were filled with 3 per cent sulphosalicylic acid, and the upper portions (1 and 5), with distilled water. To one electrode was added $\mathrm{CuCl}_{2}$ and to the other $\mathrm{NaCl}$; a silver electrode was put in the anode and a copper electrode in the cathode. The poles were connected to a light circuit with 110 volt constant current, with an ordinary lamp in the circuit as resistance. The object was to determine the 
pole to which the protein would move. The migration of the protein from the cerebrospinal fluid was detected by the formation of a precipitate with sulphosalicylic acid in the arm. This method, of course, is necessarily crude. For an accurate test it would be necessary that the $\mathrm{H}$-ion concentration, the osmotic pressure of the precipitants and of cerebrospinal fluid be the same for each experiment-a procedure almost impossible on account of the variation in the fluid. Furthermore, under these conditions, positively charged protein has a better chance of forming precipitates at the cathode, while negatively charged protein, which moves to the anode, must change its charge at the anode in order to combine with sulphosalicylic acid. In other words, the amount of negatively charged protein to be precipitated at the anode depends not only on the amount of protein that moves to the anode, but also on the strength of the acidity of the precipitating agent at the anode. Al-

\section{Table XXX}

Results of Cataphoresis on Fluid from Cases of 'Tuberculous Meningitis

\begin{tabular}{|c|c|c|c|}
\hline \multirow{2}{*}{ NUMBER } & \multirow{2}{*}{$\begin{array}{l}\text { TIME AFTER } \\
\text { WITHDRAWAL }\end{array}$} & \multicolumn{2}{|c|}{ CATAPIORESIS } \\
\hline & & Cathode & Anode \\
\hline 1 & 2 hours & $\downarrow$ & $\frac{1}{\square}$ \\
\hline 1 & 2 days & $\frac{1}{4}$ & 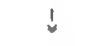 \\
\hline 1 & 2 days & $\downarrow$ & $!$ \\
\hline 2 & 2 hours & $\downarrow$ & $\vdots$ \\
\hline 2 & 3 hours & $\downarrow$ & $!$ \\
\hline 3 & 1 day & $\downarrow$ & $!$ \\
\hline 4 & 3 hours & $\downarrow$ & $!$ \\
\hline 5 & $2+$ hours & $\downarrow$ & $!$ \\
\hline
\end{tabular}

$\checkmark$ Indicates heavy precipitate.

$\downarrow$ Slight precipitate. 
TABLE XXXI

Results of Cataphoresis ox Fluids from Epinemic Mexingitis

\begin{tabular}{|c|c|c|c|c|}
\hline \multirow{2}{*}{ SUMBER } & \multirow{2}{*}{ INTERYAL } & \multicolumn{2}{|c|}{ CATAPHORESIS } & \multirow{2}{*}{ REMIARKS } \\
\hline & & Cathode & Anode & \\
\hline 1 & 1 day & $!$ & $\downarrow$ & \\
\hline 1 & 1 day & 1 & $\downarrow$ & \\
\hline $\mathscr{2}$ & 20 hours & 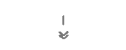 & $\downarrow$ & \\
\hline 2 & 3 days & $!$ & $\downarrow$ & \\
\hline 3 & 3 days & 1 & $\downarrow$ & \\
\hline 3 & 2 days & $\downarrow$ & $!$ & Fluid bloody \\
\hline 3 & 3 hours & ! & $\downarrow$ & 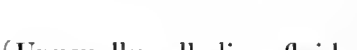 \\
\hline $\begin{array}{l}4 \\
5\end{array}$ & $\begin{array}{l}8 \text { hours } \\
3 \text { hours }\end{array}$ & $\downarrow$ & $\begin{array}{l}1 \\
\vdots \\
\vdots \\
y\end{array}$ & $\left\{\begin{array}{l}\text { Onusually alkaline flund; } \\
\text { cases brought in from } \\
\text { another hospital; ad- } \\
\text { ministration of serum } \\
\text { not ascertained. }\end{array}\right.$ \\
\hline 6 & $\ldots \ldots \ldots$ & 1 & $\downarrow$ & \\
\hline 6 & 17 hours & $\dot{q}$ & $\downarrow$ & \\
\hline 7 & $\ldots \ldots \ldots$ & 1 & $\downarrow$ & 1 \\
\hline 7 & 2 days & $\frac{1}{2}$ & $\downarrow$ & \\
\hline
\end{tabular}

I Indicates heavy precipitate.

$\downarrow$ Slight precipitate.

though this method is quite crude it is convenient for detecting the charge of protein in the cerebrospinal fluid.

Tables XXX and XXXI show some of the results obtained on cerebrospinal fluid with the cataphoresis experiment.

As is seen from the tables, a considerable amount of the protein in epidemic meningitis moves toward the cathode, showing the presence of positively charged protein in the cerebrospinal fluid of that disease. In tuberculous meningitis, however, the precipitate moves toward the anode, 
showing that the protein in that case is negatively charged. This again indicates the occurrence of specific biochemical changes in various diseases.

\section{The Colloidal Gold Reaction}

Lange has applied the work of Zsigmondy who found definite measures of the protective action of colloids on the precipitation of gold suspensions by sodium chloride, to the protein of cerebrospinal fluid. Lange found that normal cerebrospinal fluid when diluted with 0.4 per cent solution of sodium chloride bees not affect the solution of colloidal gold, while pathologic fluid produces characteristic changes for various diseases. The exact mechanism of the gold cliloride reaction is not well known, but we have here a distinct physicochemical reaction that not only signifies the existence of a pathologic state of affairs, but also indicates its nature as this test produces specific discolorations in certain diseases.

\section{Mastic Reaction}

The Lange test has been simplified by Emanuel by employing a solution of mastic, the resin of the bark of Pistacia lentiscus, a tree of the Terebinthaceac. The mastic test works on the same principle as the Lange, and further corroborates the physicochenical specificity of disease.

\section{Ninhydrin Reaction}

Noble has applied the ninhydrin reaction of Abderhalden to the cerebrospinal fluid and found that in tuberculous meningitis a blue to a blue-violet color appears on boiling 0.5 to 1 c.c. of spinal fluid with 0.1 c.e. of 1 per cent ninhydrin solution for about one-half minute. Other worker's have confirmed his observations. 


\section{Changes in the Reaction of the Cerebrospinal Fluid}

Kopetzky applied the acidosis theory of Fischer to cerebrospinal fluid, claiming that the fluid presents an acidity of varying degree in all conditions which give rise to pressure symptoms of the brain. Kopetzky used litmus paper for his determination of the reaction and he also titrated the cerebrospinal fluid against decinormal sodium hydroxide solution. He expressed his results in grains of decinormal hydrochloric acid solution, estimated for 100 c.c. of cerebrospinal fluid, using a one per cent phenolphthalein solution as an indicator.

I studied the reaction of cerebrospinal fluid in disease from various points of view using the titration, the $\mathrm{H}$-ion concentration and the alkaline reserve methods for this purpose. Originally I determined the reaction of the cerebrospinal fluid by titrating the fluid against $\mathrm{n} / 100$ sulphuric acid. The following method was used:

In each of three Erlenmeyer flasks with a capacity of 50 c.c., 20 c.c. of distilled water was measured, all of the flasks being of the same height and width. Into each flask was put 1 drop of a 0.2 per cent solution of methyl red. This produced a straw-red color which was the neutral point. Then 1 c.c. of the fluid to be examined was placed in one of the flasks by means of a graduated pipette. This turned the solution still deeper yellow. The flask was now titrated with $n / 100$ sulphuric acid until the neutral point was obtained. This was compared with the other two flasks, all three flasks being placed on a porcelain stand. When the neutral point was reached the reading was taken and then one more drop of the sulphuric acid was introduced. A bright red color appeared. In order to check the result 1 drop of $n / 100 \mathrm{NaOH}$ was added. This gave the solution a straw color. Another drop was added which changed it to yellow, thus proving that the end point had not been overrun. This procedure gave no difficulty in obtaining a sharp end point. 
With this method it was found that normal or nonmeningitic fluid required between 1.5 and 2.6 c.c. $\mathrm{n} / 100$ to reach the end point which would correspond to an alkaline reserve varying between 33 and 58 per cent total $\mathrm{CO}_{2}$. Fluid from epidemic meningitis required between 0.7 and 1.3 c.c. of $\mathrm{n} / 100$ sulphuric acid which would correspond to an alkaline reserve varying between 18 and 29 per cent total $\mathrm{CO}_{2}$ and fluid from pnemmococcus meningitis, the same amount. Tuberculous meningitis, however, acted the same as nonmeningitic fluid, requiring 1.5 to 2.6 c.c. of $11 / 100 \mathrm{sul}-$ phuric acid to reach the end point. (Table XXXII.)

After I had completed my investigation of the reaction of the cerebrospinal fluid by means of this titration method, it was realized that the fluid on which the work had been done had been standing too long before examination to give an accurate idea of the real acidity of the fluid. I was also aware of the fact that the titrable acidity did not represent the true hydrogen-ion concentration of the fluid although it does tell the titrable acidity or alkaline reserve. I, therefore, decided to determine whether there was a similar variation in the free hydrogen-ion concentration between the normal and meningitic fluids of special types. To make the test the gas-chain method of Michaelis was used, and, benefiting by the experience with nonmeningitic fluid, I endeavored to examine fluid as soon after removal from the body as possible. To carry out the immediate examination it was often necessary to resort to the indicator method, using the Levy-Rowntree-Marriott standard and a special indicator, checking both indicators by the gas-chain apparatus. In over a hundred cases of meningitis examined and checked by the above methods, the following observations were made:

Fluid from cases of tuberculous meningitis differed in no respect from that of normal eases, the $P_{n}$ being 7.4-7.6 immediately after withdrawal and ascending to 8.1 or 
TABLE XXXII

Titration of Cerebrospisal Fluid With Methyl Red as Indicator

\begin{tabular}{|c|c|c|c|c|c|}
\hline CASE & $\mathrm{AGE}$ & DLAGNOSIS & 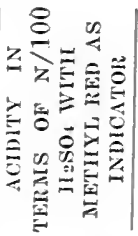 & OTHER TESTS & REMARKS \\
\hline
\end{tabular}

A-NONMENINGITIC

\begin{tabular}{|c|c|c|c|c|}
\hline 1 & 11 yrs. & Epilepsy & 2.2 с.с. & Negative \\
\hline 2 & 12 yrs. & Typhoid & 2.2 & Negative \\
\hline 3 & 8 yrs. & Encephalitis (?) & 2.4 & Negative \\
\hline \pm & 40 yrs & Lues & 2.2 & $\begin{array}{l}\text { Wassermann } \\
\text { Positive }\end{array}$ \\
\hline 5 & Adult & $\begin{array}{l}\text { Cerebrospinal } \\
\text { lues }\end{array}$ & 1.8 & $\begin{array}{c}\text { Wassermanu } \\
\text { Positive }\end{array}$ \\
\hline 6 & Adult & Insanity & 1.9 & Negative \\
\hline 7 & Adult & Insanity & 2.0 & Negative \\
\hline S & Adult & Nephritis & 2.2 & Negative \\
\hline 9 & $11 \mathrm{mos}$. & $\begin{array}{c}\text { Otitis media, } \\
\text { pneumonia }\end{array}$ & 1.5 & Negative \\
\hline 10 & $51 / 2$ mos. & Erysipelas & 1.9 & Negative \\
\hline
\end{tabular}

B-MENINGITIC

\begin{tabular}{|c|c|c|c|c|c|}
\hline 11 & $11 \mathrm{yrs}$. & $\begin{array}{l}\text { Meningococeus } \\
\text { meningitis }\end{array}$ & $\begin{array}{l}0.9 \text { c.c. } \\
\text { Before } \\
\text { serum }\end{array}$ & $\begin{array}{l}\text { Increased pressure. } \\
41,200 \text { cells, } 100 \% \\
\text { polymorphonirelear. } \\
\text { Meningococei in } \\
\text { smear and eult ure. }\end{array}$ & $\begin{array}{l}\text { After } 3 \\
\text { doses of } \\
\text { serum } \\
\text { aeidity } \\
2.0 \text { c.c. }\end{array}$ \\
\hline 12 & $10 \mathrm{yrs}$. & $\begin{array}{l}\text { Meningoroceus } \\
\text { meningitis }\end{array}$ & $\begin{array}{l}0.9 \text { c.e. } \\
\text { Before } \\
\text { serum }\end{array}$ & $\begin{array}{l}9,400 \text { cells, } 99 \% \\
\text { polymorphonuclear. } \\
\text { Meningococci in } \\
\text { smear and eulture. }\end{array}$ & \\
\hline 13 & 4 yrs. & $\begin{array}{l}\text { Meningococeus } \\
\text { meningitis }\end{array}$ & $\begin{array}{l}0.7 \text { e.c. } \\
\text { Before } \\
\text { serum }\end{array}$ & $\begin{array}{l}\text { Several thousand } \\
\text { cells per c.mm. } \\
95 \% \text { lymphoeytes. } \\
\text { Meningococeus in } \\
\text { direct smear and } \\
\text { culture. }\end{array}$ & $\begin{array}{l}\text { After } \\
\text { serum } \\
1.5 \text { e.c. }\end{array}$ \\
\hline 14 & & $\begin{array}{l}\text { Pneumococcus } \\
\text { meningitis }\end{array}$ & 0.9 c.e. & $\begin{array}{l}\text { Chemical tests } \\
\text { positive. } \\
\text { Pneumococei in } \\
\text { culture. }\end{array}$ & \\
\hline 15 & & $\begin{array}{l}\text { Pneumococeus } \\
\text { meningitis }\end{array}$ & 1.1 e.e. & $\begin{array}{l}\text { Pneumococens in } \\
\text { enlture. }\end{array}$ & \\
\hline 16 & 3 yrs & $\begin{array}{l}\text { Tnlereulons } \\
\text { meningit is }\end{array}$ & 1.9 e.e. & $\begin{array}{l}\text { Tubercle bacilli } \\
\text { found in C.S. fluid. }\end{array}$ & \\
\hline 17 & 20 mos. & $\begin{array}{c}\text { Tulerenlons } \\
\text { meningitis }\end{array}$ & $\begin{array}{l}2 \text { c.e. } \\
2.1 \text { c.c. }\end{array}$ & $\begin{array}{l}\text { All chemical tests } \\
\text { positive. Autopsy. }\end{array}$ & \\
\hline
\end{tabular}


higher. In some tuberculous fluids the H-ion concentration decreased in a much shorter time than in normal fluid (Table XXXTII).

\section{TABLE XXXIII}

$\mathrm{H}^{+}$Concentration of Fluib from Tuberculous Meningitis

\begin{tabular}{|c|c|c|c|c|c|c|c|c|c|c|c|}
\hline \multirow{2}{*}{ No. } & \multicolumn{11}{|c|}{$\mathrm{P}_{\mathbf{H}}$} \\
\hline & $\begin{array}{c}\text { Imme- } \\
\text { diate }\end{array}$ & $\begin{array}{c}1 / 2 \\
\text { Hour }\end{array}$ & $\begin{array}{c}1 \\
\text { Hour }\end{array}$ & $\begin{array}{c}2 \\
\text { Hours }\end{array}$ & $\left|\begin{array}{c}3 \\
\text { Hours }\end{array}\right|$ & \begin{tabular}{c|}
4 \\
Hours
\end{tabular} & $\begin{array}{c}5 \\
\text { Hours }\end{array}$ & $\begin{array}{c}12 \\
\text { Hours }\end{array}$ & $\mid \begin{array}{l}18 \\
\text { Hours }\end{array}$ & $\begin{array}{c}24 \\
\text { Hours }\end{array}$ & $\begin{array}{l}2 \text { Days } \\
\text { orOver }\end{array}$ \\
\hline $\begin{array}{r}1 \\
2 \\
3 \\
4 \\
5 \\
6 \\
7 \\
8 \\
9 \\
10 \\
11 \\
12 \\
13 \\
14 \\
15 \\
16 \\
17 \\
18 \\
19 \\
20 \\
21 \\
22 \\
23\end{array}$ & $\begin{array}{l}\cdots \\
7.4(\mathrm{~b}) \\
7.4(\mathrm{~b}) \\
7.4 \text { (b) } \\
7.4(\mathrm{~b}) \\
7.4 \text { (b) } \\
7.4 \text { (b) } \\
7.4(\mathrm{c}) \\
\ldots \ldots \ldots \\
\ldots \ldots \ldots \\
7.4(\mathrm{c}) \\
7.4(\mathrm{c}) \\
\ldots \ldots \ldots\end{array}$ & 7.6 (c) & $\begin{array}{l}7.6(\mathrm{c}) \\
\ldots \ldots \\
7.6(\mathrm{c})\end{array}$ & $\begin{array}{l}7.8(\mathrm{c}) \\
7.75(\mathrm{a}) \\
7.7(\mathrm{c}) \\
\ldots \ldots\end{array}$ & $\mid \begin{array}{l}7.8(\mathbf{c}) \\
\cdots \cdots \cdots \\
\cdots \cdots\end{array}$ & $\mid \begin{array}{c}\cdots \cdots \\
\cdots \cdots \\
\cdots \cdots \\
8.1 \\
\cdots \cdots \\
\cdots \cdots \\
\cdots\end{array}$ & 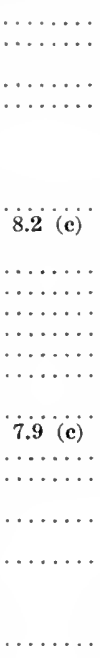 & 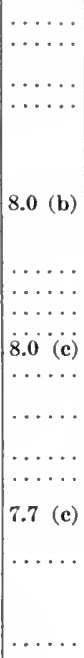 & 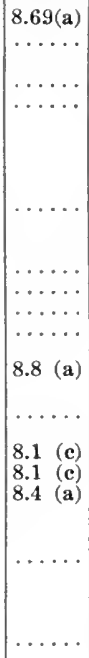 & $\begin{array}{l}8.0+(b) \\
\\
8.2(c) \\
8.2(c) \\
\cdots \cdots \cdots \cdots \\
\cdots \cdots \cdots\end{array}$ & $\begin{array}{l}8.6(\mathrm{~b}) \\
8.6 \text { (b) }\end{array}$ \\
\hline
\end{tabular}

* Corked

Fluid from cases of epidemic meningitis showed an H-ion concentration slightly higher than that of normal, the $P_{H}$ being 7.2 to 7.5 immediately after withdrawal, the average being 7.3. The greatest deviation from normal, however, was observed in fluid allowed to stand, the H-ion concentration then decreasing slowly in some cases, remaining stationary in others, and increasing in still others. Usually the graver the condition of the patient, the more turbid the fluid, and the longer the retention of the acidity. Administration of serum altered the H-ion concentration of the flujd, generally decreasing it. Cases of pneumococ- 
cus meningitis showed a strong resemblance to those of epidemic meningitis. (Tables XXXIV and XXXV.) (Fig. 31.)

The slightly higher H-ion concentration of the fluid in epidemic meningitis as compared to normal, on immediate examination of the fluid, can be explained, I believe, by the bacterial fermentation of the dextrose in the fluid as indicated by the absence of sugar or the lessened amount of it in meningococcus meningitis-a fact

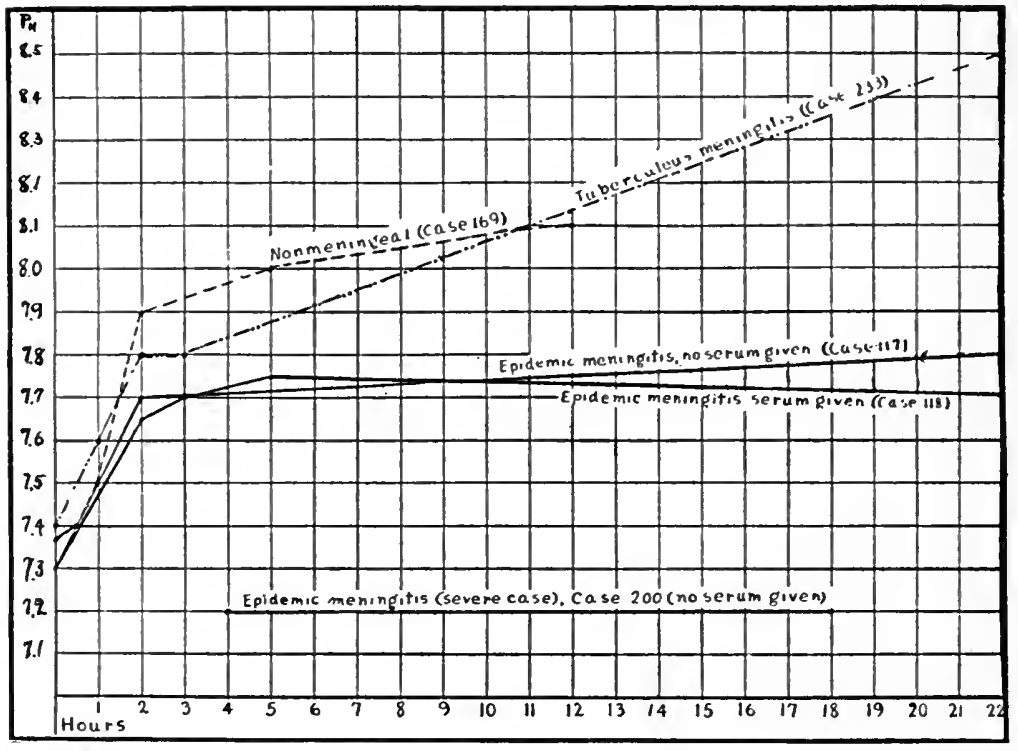

Fig. 31.-Change in the $\mathrm{H}+$ concentration of three types of cerebrospinal fluid.

that has been brought out by several investigators. As for the mechanism responsible for the slow decrease in the $\mathrm{H}$ ion concentration of epidemic fluid, there are several possibilities to be considered, such as a slower loss of $\mathrm{CO}_{2}$ in the fluid upon standing, a constant $\mathrm{CO}_{2}$ production by the cells present in the sediment of the fluid; lactic acid formation due either to further fermentation of sugar by the bacteria in the test tube or to a destruction of the cells on standing of the fluid. 
TABLE XXXIV

$\mathrm{H}^{+}$Concentration of Fluid of Epidemic Meningitis Before Admistipaton OF SERUM

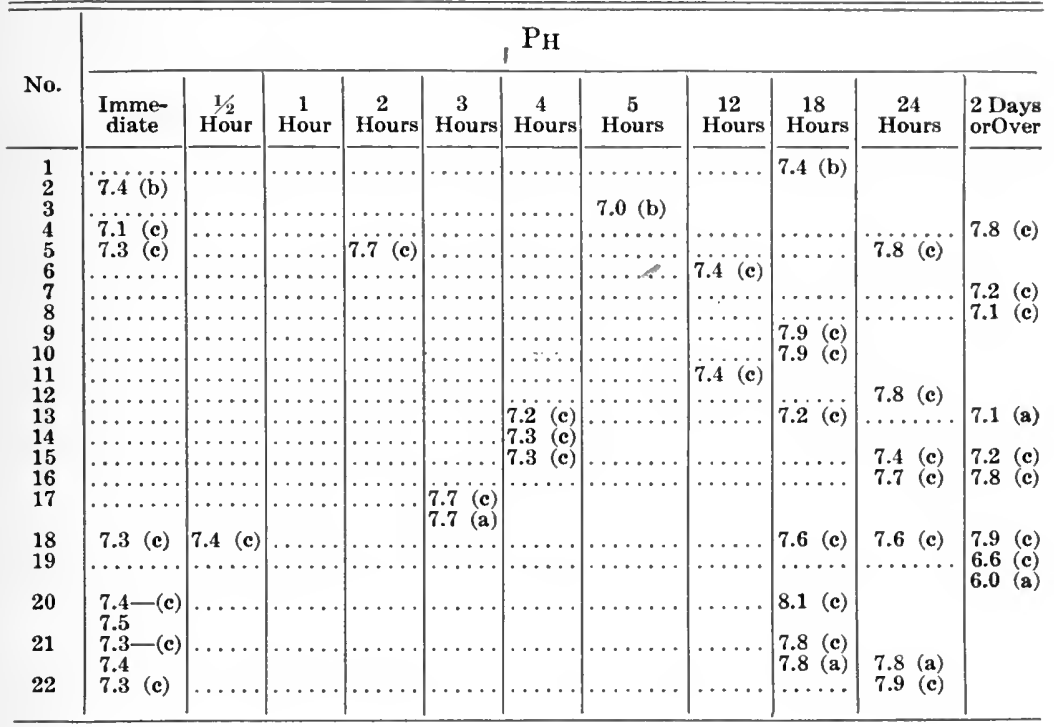

TABLE XXXV

H-Ion Concentration of Fluid of Epidemic Meningitis After Adinistration OF SERUM

\begin{tabular}{|c|c|c|c|c|c|c|c|c|c|c|c|}
\hline \multirow{2}{*}{ No. } & \multicolumn{11}{|c|}{$\mathrm{P}_{\mathbf{H}}$} \\
\hline & $\underset{\text { diate }}{\text { Imme- }}$ & $\begin{array}{l}1 / 2 \\
\text { Hour }\end{array}$ & $\begin{array}{c}1 \\
\text { Hour }\end{array}$ & $\stackrel{2}{\text { Hours }}$ & $\begin{array}{c}3 \\
\text { Hours }\end{array}$ & $\begin{array}{c}4 \\
\text { Hours }\end{array}$ & $\begin{array}{c}5 \\
\text { Hours }\end{array}$ & $\begin{array}{c}12 \\
\text { Hours }\end{array}$ & $\begin{array}{c}18 \\
\text { Hours }\end{array}$ & $\begin{array}{c}24 \\
\text { Hours }\end{array}$ & $\begin{array}{l}2 \text { Days } \\
\text { orOver }\end{array}$ \\
\hline $\begin{array}{r}1 \\
2 \\
3 \\
4 \\
5 \\
6 \\
7 \\
8 \\
9 \\
9 \\
10 \\
11 \\
12 \\
13 \\
14 \\
15 \\
16 \\
17\end{array}$ & 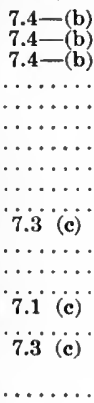 & 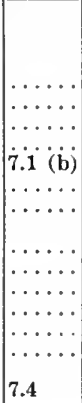 & $\begin{array}{l}\cdots \\
\cdots \\
\cdots\end{array}$ & 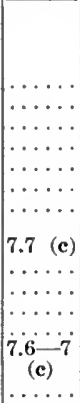 & 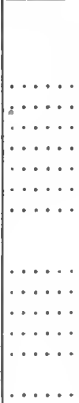 & $\begin{array}{l}7.0(b) \\
\cdots \cdots \\
\cdots \cdots \\
\cdots \cdots \\
\cdots \cdots \\
\cdots \cdots \\
\cdots \cdots \\
\end{array}$ & 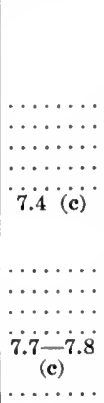 & 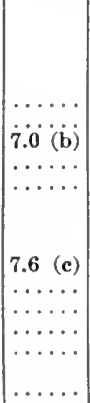 & $\begin{array}{l}7.4(\mathrm{~b}) \\
7.4(\mathrm{~b}) \\
\ldots \ldots \\
7.8(\mathrm{c}) \\
7.9(\mathrm{c}) \\
8.1 * \\
\ldots \ldots \\
8.2\end{array}$ & 7.1 (c) & 7.4 (b) \\
\hline
\end{tabular}

* Diagnosis was not settled. 
I found that the H-ion concentration of these fluids increased from 7.4 to 7.0 upon standing in tubes tightly corked, thus indicating that there is not only no loss of $\mathrm{CO}_{2}$, but that there is also a formation of certain acids on standing. Nonmeningitic and tuberculous fluids give quite different results (Tables XXXVI and XXXVIT). (Fig. 32.)

With the view of further ascertaining the cause of this increase of acidity the following experiments were made:

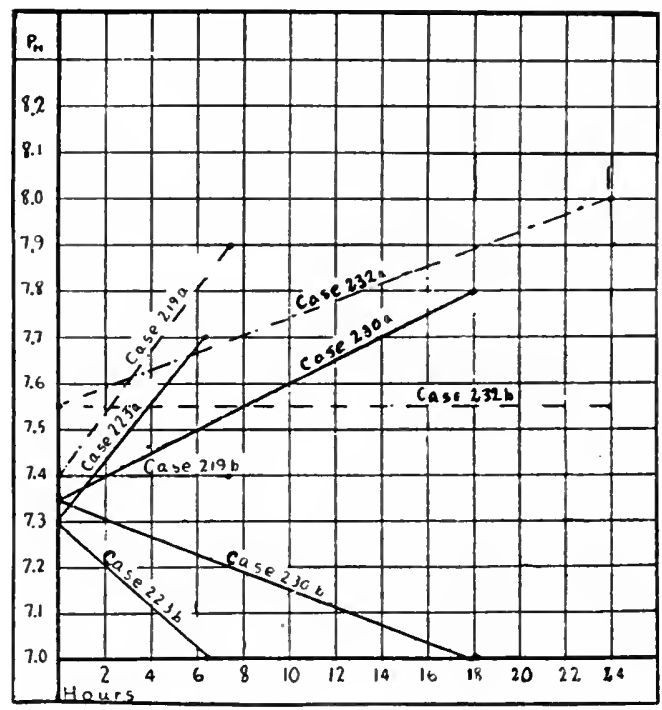

Fig. 32.-Different effects of corking on tuberculous and epidemic fluids. Case 219a, tuberculous meningitis, cotton plugged; b, same fluid, tightly corked (no air above). Case 232a, tuberculons meningitis, cotton plugged; b, same fluid, corked (no air above). Case 223a, epidemic meningitis, cotton plugged; b, same fluid, tightly corked (no air above); Case 230a, epidemic neningitis, cotton plugged; b, same fluid, tiglitly corked (no air above.)

In one chamber of the biometer (Tashiro) was put 1 c.c. of tuberculous meningitic fluid, and exactly the same amount of epidemic fluid in the other chamber. It was found that the tuberculous fluid gave off more $\mathrm{CO}_{2}$ than the epidemic, showing that although both tuberculous and epidemic fluids give off $\mathrm{CO}_{2}$ constantly, tuberculous fluid 


\section{TABLE XXXVI}

Tuberculous Fluid, Corked

\begin{tabular}{|c|c|c|c|c|c|}
\hline FLUID & DATE DRAWN & $\begin{array}{c}\text { DATE } \\
\text { EXAMINED }\end{array}$ & INTERVAL & $\begin{array}{c}\text { IfOW } \\
\text { STOPPERED }\end{array}$ & Pи \\
\hline $\begin{array}{l}\text { B. } \\
\text { B. } \\
\text { B. }\end{array}$ & $\begin{array}{c}6 / 28 / 1 \tau \\
9: 10\end{array}$ & $\begin{array}{c}6 / 28 / 17 \\
3: 05 \\
6 / 98 / 17 \\
3: 05\end{array}$ & $\begin{array}{l}5 \text { hours } \\
5 \text { hours }\end{array}$ & $\begin{array}{l}\text { Cork } \\
\text { Cotton }\end{array}$ & $\begin{array}{l}7.4 \\
7.4 \\
7.9\end{array}$ \\
\hline A. C. & $\begin{array}{l}7 / 13 / 17 \\
11 \mathrm{arm} . \\
7 / 13 / 17 \\
7 / 13 / 17\end{array}$ & $\begin{array}{l}7 / 13 / 17 \\
11 \mathrm{a} . \mathrm{m} . \\
7 / 14 / 17 \\
11 \mathrm{a} . \mathrm{m} . \\
7 / 14 / 17 \\
11 \mathrm{a} . \mathrm{m} .\end{array}$ & $\begin{array}{l}\text { Immediately } \\
24 \text { hours } \\
24 \text { hours }\end{array}$ & $\begin{array}{l}\text { Cork } \\
\text { Cotton }\end{array}$ & $\begin{array}{l}7.5-6 \\
7.5-6 \\
8.0\end{array}$ \\
\hline
\end{tabular}

\section{TABLE XXXVII}

Fluid from Epiphaic Menixgetis, with Cork and Cotron Stopper

\begin{tabular}{|c|c|c|c|c|c|}
\hline DIAGNOSIS & $\begin{array}{l}\text { DATE } \\
\text { DRAWN }\end{array}$ & $\begin{array}{c}\text { DATE } \\
\text { EXAMINED }\end{array}$ & INTERVAL & $\begin{array}{c}\text { STOPPERED } \\
\text { WITH }\end{array}$ & $\mathrm{P}_{\mathrm{H}}$ \\
\hline $\begin{array}{l}\text { Epidemic } \\
\text { meningitis }\end{array}$ & $\begin{array}{c}6 / 30 / 17 \\
12: 20 \text { p.m. }\end{array}$ & $\begin{array}{c}6 / 30 / 17 \\
12: 20 \text { p.m. } \\
6: 35 \text { p.m. } \\
6: 35 \text { p.m. }\end{array}$ & $\begin{array}{l}\text { Immediate } \\
61 / 4 \text { hours } \\
61 / 4 \text { hours }\end{array}$ & $\begin{array}{l}\text { Paraffined cork } \\
\text { Cotton plug }\end{array}$ & $\begin{array}{l}7.3 \\
7.0 \\
7.7\end{array}$ \\
\hline $\begin{array}{l}\text { Epidemic } \\
\text { meningitis }\end{array}$ & $\begin{array}{c}7 / 6,17 \\
2: 30 \text { p.m. }\end{array}$ & $\begin{array}{c}7 / 6 / 17 \\
2: 30 \mathrm{p} . \mathrm{m} . \\
7 / 7 / 17 \\
\text { s:30 a.m. } \\
7 / 7 / 17 \\
8: 30 \text { a.m. }\end{array}$ & $\begin{array}{l}\text { Inmediate } \\
18 \text { hours } \\
18 \text { hours }\end{array}$ & $\begin{array}{l}\text { Paraffined eork } \\
\text { Cotton }\end{array}$ & $\begin{array}{l}7.4 \\
7.3 \\
8.9\end{array}$ \\
\hline $\begin{array}{l}\text { Epidemie } \\
\text { meningitis }\end{array}$ & $\begin{array}{c}7 / 11 / 17 \\
11: 30 \mathrm{a} . \mathrm{m} .\end{array}$ & $\begin{array}{l}7 / 11 / 17 \\
7 / 12 / 17 \\
4: 30 \mathrm{p.m} . \\
4: 30 \text { p.m. }\end{array}$ & $\begin{array}{l}\text { Immediate } \\
17 \text { hours } \\
17 \text { hours }\end{array}$ & $\begin{array}{l}\text { Paraffined cork } \\
\text { Cotton }\end{array}$ & $\begin{array}{c}7.4-7.5 \\
7.4 \\
8.1\end{array}$ \\
\hline $\begin{array}{l}\text { Epidemic } \\
\text { meningitis }\end{array}$ & $\begin{array}{c}7 / 11 / 17 \\
1: 30 \text { p.m. }\end{array}$ & $\begin{array}{c}7 / 11 / 17 \\
1: 30 \text { p.m. } \\
7 / 12 / 17 \\
7: 30 \text { a.m. }\end{array}$ & $\begin{array}{l}\text { Immediate } \\
18 \text { hours } \\
18 \text { hours }\end{array}$ & $\begin{array}{c}\text { Paraffined cork } \\
\text { Cotton }\end{array}$ & $\begin{array}{c}7.3-7.4 \\
7.0 \\
7.8\end{array}$ \\
\hline $\begin{array}{l}\text { Epidemic } \\
\text { meningitis }\end{array}$ & $7 / 14 / 17$ & $\begin{array}{l}7 / 14 / 17 \\
7 / 15 / 17\end{array}$ & $\begin{array}{l}\text { Immediate } \\
22 \text { hours } \\
22 \text { hours }\end{array}$ & $\begin{array}{c}\text { Paraffined eork } \\
\text { Cotton }\end{array}$ & $\begin{array}{l}7.3 \\
7.1 \\
7.9\end{array}$ \\
\hline
\end{tabular}


loses more $\mathrm{CO}_{2}$ than does epidemic. This suggests that the increased acidity in epidemic meningitis is not due to a greater production of $\mathrm{CO}_{2}$ but probably to the production of some other acid, very likely lactic acid.

Further work on the subject showed a greater amount of lactic acid in the fluid of epidenic and other forms of suppurative meningitides than in that of normal or of tuberculous meningitis. Furthermore, upon standing, the fluid of suppurative meningitides showed an increase in its lactic acid content. This was more marked in the fluids that contained many polymorphonuclear leucocytes. Many fluids that showed no acetone immediately after withdrawal, showed traces of it when allowed to stand for a day or two. These changes indicate that the increase, on standing, of the H-ion concentration of fluids from suppurative meningitides is due to a constant formation of organic acids, resulting from the decomposition of the cells in the fluid.

\section{BACTERIOLOGIC}

Cerebrospinal fluid is sterile, even after it has passed through the nose as suggested by the cases reported in the literature. Any bacteria in the fluid, is, therefore, indication of the existence of some pathologic process in the body, unless it is known that the bacteria are the result of some external contamination of the fluid after its removal.

The cerebrospinal fluid is one of the best mediums for the growth of bacteria. They grow in it luxuriantly. However, at times it is very difficult to isolate the bacteria from the fluid. Some bacteria, such as the pneumococens and streptococcus grow easily on ordinary culture media; others, notably meningococei and influenza bacilli grow only on special media and at that with difficulty, while still others, like the tubercle bacilli can hardly be grown at all. 


\section{IMMUNOLOGIC}

Immunology has thrown a great deal of light on the diagnosis and pathology of diseases related to the nervous system. The various agglutination tests help to differentiate the various types of meningococci. The hemolysin reaction indicates a permeability of the meninges. The neutralization test assists in the diagnosis of poliomyelitis, and the Wassermam test is an invaluable aid in the diagnosis of syphilis of the nervous system.

\section{Agglutination}

The agglutination test is based on the principle that various bacteria agglutinate when they are brought into contact with their respective sera. This principle is utilized for the identification of meningococei and pneumococci.

\section{Hemolysin}

It has been found by a number of observers that normal cerebrospinal fluid contains no antisheep hemolysin, whereas the spinal fluid in some cases of meningitis and poliomyelitis has been found to contain hemolysin. The hemolysin test is of value as corroborative evidence of an inflammation of the meninges although the results of the test up to date are not constant enough to be of diagnostic value.

Hauptmann found that the cerebrospinal fluid of patients suffering from lesions of the central nervous system inhibits the hemolysis of erythrocytes which is usually produced by a solution of saponin. He considers the inhibition of hemolysis in cases of this kind to be due to cholesterin produced by the degeneration of nervous tissue. 


\section{Wassermann Reaction}

The Wassermann reaction has done a great deal to change our conception of diseases in general and of syphilis in particular. Most authors consider a positive Wassermann test of the cerebrospinal fluid to be specific for syphilis of the central nervous system. Positive tests are reported to have been found in the fluid of other conditions, such as leprosy and beriberi, still it is practically pathognomonic of lues, especially in harmony with the clinical condition and the history of the case. A negative Wassermamn, however, does not always rule out syphilis.

\section{Bibliography}

Apelt and Schumm: Untersuchungen über Phosphorsäuregehalt der Spinalflüssigkeit, Arch. f. Psych., 1908, xliv, 2.

Ardin-Delteil: Note sur la toxicite du liquide cephalo-rachidien des paralytiques generaux, Montpel. Med., 1904, xviii, 103.

Austrian: Experimental Meningococeus Meningitis, Bull. Johns Hopkins Hosp., 1918, xxix, 183.

Ball: The Value of Spinal Fluid in Diagnosis, Interstate Med. Jour., 1913, $\mathrm{xx}, 1109$.

Boyd: The Clinical Importance of Cerebrospinal Fluid, Brit. Med. Jour., 1914 , i, 961.

Chmielewska: Le liquide cephalo-rachidien dans les hemorragies du nevraxe, Thèse de Genere, 1905.

Cimbal: Chem., physikal, u. morpholog. Ergebnisse an 240 Spinalpunktionen und deren diagnostische und therapentische Verwertung; Therap. d. Gegenw., 1906.

Donath: Das Vorkommen und die Bedentung des Cholins in der Zerebrospinalflüssigkeit bei Epilepsie u. organisehen Erkrankungen des Nervensystems, Ztsehr. f. physiol. Chem., 1903, xxxix, 526.

Donath: Die Phosphorsauregehalt der Cerebrospiualflüssigkeit bei verschiedenen Nervenkrankheiten, Ztschr. f. physiol. Chem., 1904, xlii, 141.

Grunberger: Über den Befund von Acetessigsaure in der Zerebrospinalflüssigkeit bei Coma diabeticum, Ztsehr. f. inn. Med., 1905, xxv, 617.

Guillain et Parant: Sur la presence d'Albumines coagulables par la chaleur dans le liquide cephalo-rachidien des paralytiques generaux, Rev. neurol., 1903 , xi, 406.

Halliburton: Biochenie der peripheren Ncrven, Ergebniss der Physiol, 1905, iv, 23.

Hauptmann: Eine biologisehe Reaktion im Liquor Cerebrospinalflüssigkeit bei organischen Nervenkrankheiten, Med. Klin., 1910, vi, 181.

Herrick: Early Diagnosis and Intravenous Serum Treatment of Epidemic Cerebrospinal Meningitis, Jour. Am. Med. Assn., 1918, lxxi, 612.

Kauffman: Über angeblichen Befund von Cholin in der Lumbalflüssigkeit, Neurol. Centralhl., 1908, xx, 966.

Kcpetzky: Meningitis, Nature, Cause, Diagnosis, and Principles of Surgical Relief, Manhattan Eye, Ear and Throat IIospital Reports, 1913.

Landois: Lehrbuch der Physiologie. 
Launois et Bonlud: Sur la Teneur en suere du liquide eephalo-rachidien, Rev. neurol., May, 1904.

Loekemann: Nachweis von Fleischmilehsaure im Blut, Urin und Cerebrospinalflüssigkeit, Münehen med. Wchnsehr., 1906, liii, 299.

Latiner: Das Verhalten des Reduktionsindex in dem normalen und pathologisehen Zerebrospinalflüssigkeit, Wien, klin. Wehnsehr., 1911, xxiv, 783.

Mayerhofer: Zur Charakteristik und Differential Diagnose des Liquor Cerebrospinalis, Wien. klin. Wehuschr., 1910, xxiii, 651.

Mott and Halliburton: The Chemistry of Cerebrospinal Fluid, Laneet, London, 1901.

Myers: The Cerebrospinal Fluid in Certain Forms of Insanity With Special Reference to the Content of Potassium, Jour. Biol. Chem., 1909, vi, 115.

Pighihi: Über den Cholesteringehalt der Lumbalflüssigkeit einiger Geisteskrankheiten, Hoppe-Seylers Ztsehr. f. pinysiol. Chem., 1909, lx, 508.

Reichmann: Zur Physiologie und Pathologie des Liquor cerebrospinalis, Deutseh. Ztschr. f. Nervenh., 1911, xlii, 279.

Rubenstone: Cerebrospinal Fluid and Its Diagnostic Significanec, New York Med. Jour., 1913, xeviii, 1210.

Tashiro: Chemieal Sign of Life, Chicago, 1917.

Thomson: A Note on Certain Peculiar Crystals Found in the Cerebrospinal Fluid from a Case of Septic Meningitis, Lancet, London, 1915, 653.

Zsigmondy: Colloids and the Ultramicroseope, New York, 1909. 


\section{CHAPTER VI}

\section{METHODS OF EXAMINATION OF CEREBROSPINAL FLUID FOR DIAGNOSTIC PURPOSES}

In the following pages I shall outline the methods employed in the examination of cerebrospinal fluid for the purpose of detecting the presence of pathologic processes. I shall describe only those methods that have been proved to be both simple and practical.

\section{PHYSICAL}

No special apparatus is required for the physical examination of the cerebrospinal fluid with the exception of that used for the determination of the pressure of the fluid. All other physical examinations can be made by the naked eye. The amount of fluid withdrawn can be measured either in a graduate or it may be estimated. If the amount of fluid easily withdrawn from the patient in recumbent position exceeds 10 c.c. a pathologic condition should immediately be suspected and the fluid carefully examined.

\section{Color}

The color of the fluid furnishes one of the best indications of the existence of an abnormal condition. Normal fluid in its natural state is colorless. Any change in color is therefore significant. The best way to examine the fluid for color is to hold it up against the light with a background of black or yellow. The glass of the tube containing the fluid should be thin enough to show the color clearly and the tube itself should always be kept in the same position toward the light. Daylight naturally is better for the observation of color than artificial light. The specific 
changes of color in different conditions, in the various types of meningitis, and in conditions known as xanthochromia and in jaundice, will be described under their respective headings.

\section{Foam}

If only five or ten c.e. of fluid is removed the tube containing the fluid should be shaken and watched for the formation of foam. The length of time the foam persists should be observed, and its character noted, as both furnish a clew as to the presence and intensity of pathologic processes.

If more than 10 c.c. is removed, the first tube, containing 2 to 3 c.c., should be put away for various examinations (Cf. Chapter III). The second tube, containing 3 to 5 c.c., should be left undisturbed for pellicle formation. The third tube, containing preferably between 9 and 10 e.c., although 5 c.c. will also do, should be tested for foam formation. After the foam has subsided, the fluid in this tube may be used for any purpose desired.

\section{Pellicle}

In looking for a pellicle, one must be careful not to disturb the fluid. It is therefore best to put the tube aside for this purpose, as soon as the fluid is collected. As for the best conditions under which a pellicle will form, no set rules can be given. Generally, a pellicle will form either at room temperature or in the cold. Мy experience has shown that a pellicle forms more easily at room temperature than on ice. Hence, the tube in which the pellicle is expected to form should be left at room temperature, absolutely undisturbed. Another point is that the pellicle must be examined not later than twenty-four hours after the withdrawal of the fluid, as autolysis often takes place, so that the pellicle undergoes changes on standing for two or three days. 


\section{CHEMICAL}

Many qualitative and quantitative chemical tests have been used by various scientific workers. Not all of the tests, however, are necessary or applicable for rontine diagnostic purposes.

The quantitative determination of urea may be of value, as urea has been found to be greatly increased in the cerebrospinal fluid in cases of uremia and nephritis and at times also in arteriosclerosis. However, since the urea content of the blood is also greatly increased in these conditions it is best to reserve this test for the determination of urea in the blood and to keep the fluid for other tests.

The determination of phosplates has not been found practical because of its uncertain diagnostic value.

The chenical examinations of the cerebrospinal fluid for diagnostic purposes should therefore be limited to albumin and globulin tests, permanganate index, sugar, and chlorides. In a rapid examination of the fluid all but the globulin test may be dispensed with as the globulin increase is the one factor common to all inflammatory processes, whereas the sugar and chloride content often remain unchanged. In making the chemical tests one should make sure that all the ressels employed are chemically clean.

\section{Increase of Protein}

A number of qualitative tests have been described for the detection of an increase in protein. One is the acetic acid test of Moritz which consists of the addition of a few drops of a 5 per cent acetic acid solution to 2 c.c. of cerebrospinal fluid. If a precipitate forms, an increase of protein is indicated. Another one is the nitric acid test. A few drops of nitric acid are added to the fluid, and a heavy cloud is produced if the protein content is increased. How- 
ever, neither of these two tests is employed to any great extent.

The quantitative protein determination has been used by various workers for the diagnosis of meningitis and other pathologic conditions. Bybee and Lorenz employed the Brandenburger method for urinalysis for the determination of albumin, Nestrezat used a colorimetric method for this purpose. Probably the simplest method for the determination of albumin in cerebrospinal fluid is the following: A glass tube, five to six millimeters in dianeter and six to six and one-half inches in lengtlı is stripped by a piece of adhesive plaster, or fastened by a rubber band to an Esbach albuminometer. 'The small tube is filled with cerebrospinal fluid to a level corresponding to mark " $\mathrm{U}$ ", on the Esbach tube, and with the Esbach reagent to a level corresponding to mark " $\mathrm{R}$ ', on the albuminometer. The two tubes are allowed to stand for twenty-four hours, and the amount of precipitate in the small tube is then read off on the Esbach albuminometer, the result being expressed in grams of albumin per liter.

\section{GLOBULIN TESTS}

Several globulin tests have been proposed. Among the most important of them are the Noguchi, Ross-Jones, Nonne-A pelt, the Pandy, and the sulphosalicylic mercuric chloride tests. In doing any globulin test one must make sure at the beginning that the fluid is perfectly free of blood. Should there be any blood present in the fluid the globulin test will be positive even if no pathologic process exists. The effect of centrifugation on the fluid is not marked. I found very little difference between the globulin reaction of centrifuged and uncentrifuged specimens. The cells present in the fluid neither interfered with nor accelerated the positiveness of the globulin test. A description of the various globulin tests follows: 


\section{Noguchi}

Two-tenths c.c. of cerebrospinal fluid is transferred by means of a pipette to a small test tube, preferably a regular Noguchi tube. Five-tenths c.c. of butyric acid solution (5 c.c. of butyric acid to 45 c.c. of physiologic salt solution) is added to the fluid; this mixture is boiled for a few seconds and 0.1 c.c. of a 4 per cent aqueous $\mathrm{NaOH}$ solution is poured into it and it is boiled again for a few seconds. If there is an increase in the globulin of the fluid a fine or coarse granular, flocculent deposit is formed in from five to twenty minutes. If no floceulence makes its appearance within two hours, or if nothing more than a slight opalescence is present, it shows that the globulin is not increased.

\section{Ross-Jones}

The Ross-Jones test consists of the superimposition of 0.3 c.c. of a saturated solution of ammonium sulphate upon an equal amount of cerebrospinal fluid. The ammonium sulphate solution is prepared in the following manner: 85 grams of ammonium sulphate is put into 100 c.c. of water and boiled in an Erlenmeyer flask until no more salt goes into solution. This is then filtered and used for the test. If the solution has an acid reaction the results will not be accurate. If the globulins in the fluid are increased an opaque ring develops at the point of contact of the fluid and ammonium sulplate.

\section{Nonne-Apelt}

Phase I.-The constituents used for the Nonne-Apelt test are the same as those used for the Ross-Jones, except that equal parts of the cerebrospinal fluid and saturated ammonium sulphate are mixed instead of being superimposed one upon the other. A white precipitation forms in three minutes if the reaction is positive (euglobulin).

Phase II.-The precipitate is filtered, one drop of a 10 per cent acetic acid is now added to the filtrate and the 
mixture is boiled. A precipitation forms if the reaction is positive (serum albumin).

Zaloziecki has modified the Nonne test, Phase I, in that he uses only 0.5 c.c. of cerebrospinal fluid instead of the original method of using 2 c.c. It has been found that 0.5 c.c. is just as accurate as is 2 c.c.

\section{Kaplan Method}

Five-tenths c.c. of cerebrospinal fluid is heated and boiled twice. Then 3 drops of a 5 per cent solution of butyric acid in physiologic salt solution is added to the test tube and is followed immediately by 0.5 c.c. of a supersaturated solution of ammonium sulphate. The mixture is now set aside for 20 minutes. An excess of globulin is indicated by a thick granular precipitate.

\section{Pandy}

One drop of cerebrospinal fluid is added to one c.c. of a concentrated solution of carbolic acid (1 part of phenol crystals to 15 parts of water). A bluish white ring or clond results if an excess of globulin is present.

\section{Sulphosalicylic Mercuric Chloride Method}

One c.c. of cerebrospinal fluid is introduced into each of two small tubes of uniform height and width, (about 0.3 $\mathrm{cm}$. in diameter); into one of the tubes 1 c.c. of a 3 per cent sulphosalicylic acid is introduced, and into the other 1 c.c. of a 1 per cent mercuric chloride. If the fluid is pathologic, a heavy precipitate forms in the tube containing the sulphosalicylic acid; if the fluid is normal only a slight turbidity appears. The tubes are then allowed to stand for twentyfour hours, after which the sediment in them is measured and compared. Under normal conditions the sediment found after 24 hours in either of the two tubes is very slight; in all suppurative meningitides, however, the precip- 
itation with the sulphosalicylic is very heary, often being three times the size of the precipitation obtained with the mercuric chloride. In tuberculous meningitis, the opposite reaction takes place, the precipitation with the mercuric chloride usually being three times as heary as that obtained with sulphosalicylic acid.

\section{Relative Value of the Globulin Tests}

It would be well to emphasize the fact that there is no one test for the diagnosis of pathologic conditions that can be considered absolutely final. Furthermore, even all the tests together are at times unreliable, unless supported by additional observations. A careful worker soon learns that to make a correct diagnosis he must take into account the entire picture of the disease gained from both clinical and laboratory observations. There are so many possibilities for error in laboratory work that unless one combines the clinical with the laboratory results, he is apt to arrive at erroneous conclusions. As for the relative value of the different tests, the experience of different workers varies. I found the sulphosalicylic mercuric chloride test the most helpful chemical or physicochemical test in the diagnosis of tuberculous meningitis. Early in the course of the disease when other tests could not be depended on for definite results this test gave a positive reaction in the diagnosis of tuberculous meningitis. Many of my colleagues report a similar experience with this test. Of the other globulin tests, the Noguchi has been found the most reliable. The Ross-Jones has at times been known to give a negative reaction when the other tests showed a positive reaction. The Nonne, Phase I, is not so sensitive as the Noguchi or even the Ross-Jones although with a well-prepared ammonimm sulphate solution the test is fairly reliable. As for the Pandy, it is very sensitive, but at times it precipitates even normal cerebrospinal fluid so that one is often at a loss to know what is the borderline between normal and pathologic fluid. 


\section{The Permanganate Test}

The test was described by Mayerhofer in 1910 for the determination of organic substances in cerebrospinal fluid, the method having originally been described by KubelThiemich for the determination of organic substances in water. Mayerhofer showed that every cerebrospinal fluid oxidizes, or, as he termed it, reduces, permanganate, and that fluid in cases of meningitis has a higher oxidation index than normal fluids or even those of meningism.

One c.c. of cerebrospinal fluid is introduced into an Erlenmeyer flask by an accurately graduated pipette; 50 c.c. of distilled water and 10 c.c. of diluted $\mathrm{H}_{2} \mathrm{SO}_{4}$ ( 1 part $\mathrm{H}_{2} \mathrm{SO}_{4}$ and three parts $\mathrm{H}_{2} \mathrm{O}$ ) are added, and the mixture is brought to a boiling point; 10 c.c. of a decinormal permanganate solution is then introduced into the flask and the solution is boiled for exactly ten minutes. At the end of this time 10 c.c. of decinormal oxalic acid is put into the flask, whereupon the red or yellowish-red color turns white. Titration is now carried on drop by drop from a burette containing the permanganate solution until the color of the solution in the receptacle turns red and remains so for a number of minutes. The number of cubic centimeters of permanganate required to produce the end reaction is then read off and the figmre is taken as the permanganate index. In doing this, one must make certain that 10 c.c. of $n / 10$ permanganate equals 10 c.c. of $n / 10$ oxalic acid. It is also necessary to ascertain how much permanganate is required to oxidize the water and the $\mathrm{H}_{2} \mathrm{SO}_{4}$ and this amount should be subtracted from the number of cubic centimeters of permanganate required to oxidize the cerebrospinal fluid solution. For example, if 4 c.e. of $n / 10$ permanganate was required for the cerebrospinal fluid and 0.5 c.c. permanganate for water and $\mathrm{H}_{2} \mathrm{SO}_{4}$, the 0.5 c.c. should be subtracted from the whole number, leaving the reduction index only 3.5. Boveri simplified the permanganate test. He uses 1 c.c. of cerebrospinal fluid and 1 c.e. of a 1 per cent permanganate 
solution. If the cerebrospinal fluid is normal, there is no change of color on contact of the fluid with the permanganate. In all pathologic fluids, a yellow ring forms on contact. When the fluid and the permanganate solution come into contact, the change in color appears in a few seconds or at most in a few minutes. The quicker the reaction, the more pathologic the fluid.

\section{Sugar}

The qualitative determination of sugar in the cereorospinal fiuid by Fehling's solution is of no special diagnostic importance as by this method only an absence of, but not a decrease in, the sugar content can be detected. The quantitative determination, however, is of diagnostic significance.

Several methods have been employed for sugar determination, the most accurate one being the Lewis and Benedict method, originally described for blood sugar. The technic is as follows: 2 c.c. of cerebrospinal fluid is put into a 25 c.c. volumetric flask containing 5 c.c. of distilled water, 15 c.c. of saturated picric acid solution is added, water filled up to 25 c.c. and the whole solution is shaken and filtered. Eight c.c. of the filtrate in duplicate are put into large Jena test tubes for determination; 2 e.c. saturated picric acid solution and 1 c.c. of a 10 per cent sodium carbonate solution are added; the contents of the tube is evaporated over the flame until precipitation occurs, 3 c.c. of water is added and the tube heated again to the boiling point, in order to dissolve the precipitate; the contents of the tube is now transferred to a 10 c.e. volumetric flask, cooled, filled up to the mark with water, shaken and filtered through cotton into a colorimetric flask; the color is compared in a Dubosque colorimeter either with a dextrose standard, freshly made up every time, or with a permanent standard consisting of $0.064-\mathrm{mg}$. picramic acid and $0.1 \mathrm{gm}$. sodium carbonate in 1000 c.c., and the results are calculated. 
Epstein described a rapid microchemical method for the determination of sugar in the blood which I believe may easily be applied also to the cerebrospinal fluid. The principle is the same as that of the Lewis-Benedict method, except that a permanent standard is used and smaller quantities of the fluid to be tested are used. It differs from the blood sugar test in that in the determination of sugar in the cerebrospinal fluid, no sodium fluoride or potassium oxalate has to be used as is the case in sugar of the blood. The apparatus consists of the following:

(a) Sahli-Gower hemoglobinometer stand and a graduated tube.

(b) Two standard color tubes, one for measuring quantities of sugar ranging from 0.05 to 0.1 per cent and the other for measuring quantities of sugar over 0.1 per cent.

(c) A test tube ( $1 / 2$ by 4 inches) graduated at 1.0 c.c. and 2.5 c.c.

(d) A special pipette graduated at 0.1 c.c. and 0.2 c.c. (As will be seen later, this pipette may be dispensed with.)

(e) A test tube suitable for boiling fluid.

The procedure is as follows: 0.2 c.c. of cerebrospinal fluid is drawn up with the pipette of the apparatus or any other graduated pipette into the large graduated test tube. Distilled water is then drawn up into the pipette and discharged into the graduated test tube, till the fluid reaches the 1.0 e.c. mark; picric acid is added to the 2.5 c.c. mark, and the tube shaken vigorously; the contents are filtered through a small filter, or centrifuged for 2 to 3 minutes; 1 c.c. of the filtrate is now withdrawn, put into the boiling tube and heated carefully over the naked flame. The contents of the tube is boiled until all but 2 or 3 drops of the solution is evaporated. Five-tenths c.c. of a 10 per cent soda solution is now added and the tube heated again until the contents are down to a few drops, the color of the fluid being changed from yellow to deep red or reddish brown. Three or four drops of distilled water are added and the 
tube warmed gently. The contents are next transferred to graduated tube 1 . The boiling tube is rinsed several times with a few drops of water, the tube being warmed with each rinsing. The volume of the fluid is then made up to mark 50 on the scale. The color of the resulting solution is now compared with one of the two standard tubes A or B. If the fluid tested is darker than the standard A which represents 0.05 per cent of sugar, and is lighter than standard B which represents 0.1 per cent of sugar, the first standard is used for comparison. The solution in the graduated tube is gradually diluted with water until the color matches. The percentage of sugar on using standard A is figured out. Each reading on scale being 1/1000. For example, if the reading is 86 then $86 / 1000=0.086$ per cent. If $B$ is used, the figure on the scale is multiplied by 2 divided by 1000. For example, if the reading is 73 , then $73 \times 2$ 1000

I have clecked the Epstein method against the Dubosque colorimetric with a standard solution of dextrose. The determination by Epstein method usually gave a higher reading of dextrose than the amount originally started with. The percentage of error, however, was small. I think it could be accounted for by the fact that the picramic used by Epstein in the standard tubes loses some of its potency in time; the result of it being that the solutions to be tested gave a higher percentage of sugar than the solution really contained. I have also encountered difficulty in using the pipette designated by Epstein for drawing up the fluid. The lumen of the pipette was too large so that when I succeeded in getting 0.2 c.c. of cerebrospinal fluid, the fluid would rum out of the tube before I had a chance to empty it into the test tube. This difficulty, howerer, was done awaywith by calibrating my own tubes, using graduated pipettes and ordinary centrifuge tubes for that purpose, so that I had a double check on the amount used. I let the spinal 
fluid drop down into the centrifuge tubes np to the 0.2 c.c. mark on the tube, using the same tube for the purpose of centrifugation.

\section{Chlorides}

For the quantitative estimation of chloride in the cerebrospinal fluid, the Seelman method originally described for the determination of chloride in urine is the most practical. It requires only 0.5 c.c. of fluid and the results are quite accurate.

Two solutions are prepared for the test. Solution 1 consists of the following:

Anhydrous, crystallized silver nitrate, (C. P.)...........29.055 gm. $25 \%$ nitric acid in distilled water.......................

Cold saturated solution of ammonioferric alum in distiljed

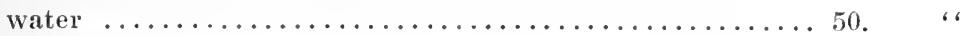

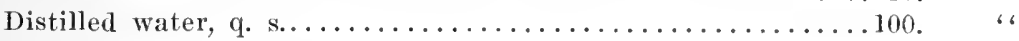

Solution 2 consists of:

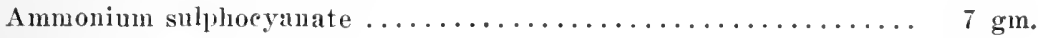

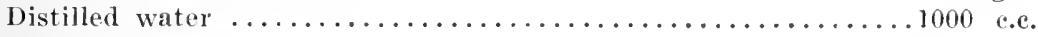

Solution 2 is intentionally made too strong, and must be standardized by adding distilled water in such an amount that exactly the last drop of 2 c.c. of this solution will bring about the end reaction when added to 1 c.c. of Solution 1 . The end reaction consists of a reddish-brown color, which does not disappear on moderate stirring. If the second last drop produces a discoloration which disappears rather slowly, and the last drop a deep brown color, the solntion must be still further diluted, until the discoloration on the addition of the last drop is a light reddish-brown, which does not disappear on stirring fifteen to twenty seconds.

The test proper is made as follows: 0.5 c.c. of cerebrospinal fluid to be tested is placed in a porcelain dish, 1 c.c. of Solution 1 is then added and the mixture is stirred for about a minute with a glass rod. Solution 2 is now added drop by drop by moans of a 2 cee pipete graduated to at 
least .05 c.c. and the mixture is stirred until the brown color developing after "ach drop disappears. The amount of Solution 2 which has been used to bring about the end reaction is now read off, and the difference between this and 2 is equal to the number of grams of sodium chloride per 100 c.c. of the specimen tested. If for example, it takes 1.26 c.c. of Solution 2 to bring about the end reaction, the amount of chloride in 100 c.c. of cerebrospinal fluid equals 2. - 1.26 which equals 0.74 per cent of chlorides.

\section{PHYSICOCHEMICAL METHODS}

If determined accurately, specific gravity, viscosity, surface tension and freezing point, are of some value in elucidating diagnosis of pathologic conditions. However, since accurate determinations of physicochenical constants require a great deal of care and consmme a good deal of time, I do not recommend most of them for routine laboratory use. I believe, for instance, that specific gravity, to be of any value, should be determined by a pyknometer, the determination of specific gravity by the urinometer method being very inaceurate, and requiring more fluid than can be spared even in pathologic conditions. The pyknometer, however, is a delicate instrument, and consumes a. great deal of time in drawing up the fluid withont bubbles, in weighing the instrument, and also in keeping it at a constant temperature. It is, therefore, best to leave it out in ordinary laboratory work.

The determination of the H-ion concentration and of the alkaline reserve of cerebrospinal fluid, howerer, is of greater value than some of the other physicochemical constants. As has been shown in Chapter $V$ the H-ion concentration and the alkaline reserve varies in the different types of meningitis especially after the fhid stands uncorked. This makes it of diagnostic importance to say nothing of the scientific interest attached to it. I wonld, therefore, ad- 
vise to determine the H-ion concentration and the alkaline reserve whenever a sufficient amount of cerebrospinal fluid can be spared after other more important tests have been made. The method for the H-ion concentration in rontine laboratory work, I. would recommend, is that of LevyRowntree-Marriott. This method requires only 3 c.c. of cerebrospinal fluid and very few apparatus. The gas-chain method, although more exact, requires 7 to 8 c.c. of fluid and is highly complicated. The technic of the Levy-Rowntree-Marriott method is as follows:

Three c.c. of cerebrospinal fluid is collected directly from the lumbar puncture needle, or from another test tube into a nonsol glass tube. To this is added 0.2 c.c. of the indicator which consists of a solution of 0.01 per cent of phenolsulphonephthalein. The tube with the cerebrospinal fluid is now compared in a special stand with one of the series of sealed standards ranging from a $P_{H}$ of 6.6 to a $\mathrm{P}_{\text {н }}$ of 8.6.

If sufficient fluid has been obtained, it is advisable to determine the H-ion concentration immediately after the fluid has been removed from the body and also several hours later. If no large amount of fluid can be spared, the H-ion concentration should be determined only once, immediately after the removal of the fluid from the body. It must always be kept in mind that the $\mathrm{H}$-ion concentration changes on standing and the time factor must be taken into consideration in order to arrive at any conclusion.

Some anthors have used a dialyring tube for the determination of the H-ion concentration of the cerebrospinal fluid by the indicator method. I have, however, fomd that with the exception of severe cases of epidemic meningitis where the protein content is very high, no dialysis is necessary and that the result obtained by the indicator method corresponds quite well with those obtained from the gas-chain method, especially in $P_{и}$ reading of 7.0 to 8.1 
For the determination of the alkali reserve, the Van Slyke method is the most accurate and requires the least amount of fluid.

\section{Lange Gold Chloride Test}

The Lange test is a very sensitive one and is quite helpful in detecting various forms of syphilis of the nervous system and often also in discovering the type of meningitis. It is a test, however, which calls for extraordinary care and precision on the part of the one who is making it. To begin with, the vessels in which the solutions are used must be perfectly clean. Secondly, the vessels must be neutral in reaction. Thus, after the glassware has been cleaned with bichromate solution, for instance, sufficient water should be run through the vessels to make the reaction nentral. The water used in making up this solution must be doubly distilled, and if possible, trebly distilled. The pipettes used for measuring the cerebrospinal fluid and sodium chloride solution must be accurately graduated. Great care must also be taken not to blow the pipette in emptying the solution, for the introduction of saliva or carbon dioxide into the solution will greatly interfere with this delicate physicochemical reaction. There is one point, however, in which the Lange test requires less precaution than other tests and that is, in the matter of the time intervening between the drawing of the cerebrospinal fluid and the application of the test. While in an examination for pellicle or for the cells of the cerebrospinal fluid time of standing is a great factor, the examination with colloidal gold may be made, even after the cerebrospinal fluid has been standing for some time. The solution for the test is prepared in the following manner:

To 1000 c.e. of doubly distilled water, which is heated slowly to $60^{\circ}$ C., 10 c.c. of a 1 per cent gold chloride solution and 7 c.c. of a 2 per cent solution of $\mathrm{K}_{2} \mathrm{CO}_{3}$ are added. 
The mixture is then rapidly heated to $90^{\circ} \mathrm{C}$. The flame is then removed and 5 c.c. of a 1 per cent formaldehyde solution is added quickly. The solution should at once assume a ruby red color. The solution when ready for use should be transparent, should be neutral in reaction, and should be precipitated by 1.7 c.c. of a 1 per cent sodium chloride solution in one hour. The solution usually remains indefinitely without spoiling, although it is best to keep it in a bottle wrapped in dark paper.

The technic of examining cerebrospinal fluid for the colloidal gold test is as follows :

A series of 10 large test tubes are put in a test tube rack and numbered. In the first test tube 0.2 c.c. of cerebrospinal fluid is poured and to it is added 1.8 c.c. of a 0.4 per cent solution of sodinm chloride. Into each of the other tubes, 1 c.c. of sodium chloride is poured. The contents of the first tube are then thoroughly mixed and 1 c.c. of the amount is poured into the second tube. The contents of the second tube are then mixed and 1 c.c. of its solution is emptied into the third tube. And so the processes continue with all the tubes, until 1 c.c. of the solution in the ninth tube has been emptied into the tenth tube. The solution in the tenth tube is then thoroughly mixed and 1 c.c. of its contents is removed and discarded. This leaves each tube with a content of 1 c.c. and gives the following series of dilution $1: 10,1: 20,1: 40,1: 80,1: 160,1: 320,1: 640 ; 1: 1280$; $1: 2560,1: 5120$. Five c.e. of the prepared colloidal gold solution is then added to each test tube and the tubes are put away and the changes taking place in them observed. Generally some change occurs in a very short time, but it is best not to attempt to judge the reaction before the lapse of an hour and it is still better to wait until the next day, for sometimes it takes 24 hours for a completion of the reaction. The tubes should be read in daylight as artificial light may cause a false interpretation of the changes. 


\section{Mastic Test}

The mastic test which has been described by Emannel has been used by some observer's with success anci those observers recommend it for use in routine examination of cerebrospinal fluid. The principle is the same as that of the Lange gold chloride and the advantage. claimed for this test is the fact that the mastic solution is easily made up, much more easily than the gold chloride solution. Until we get further data on the subject, I would suggest that between the two tests, the Lange and the mastie, the first is preferable. However, when time permits, the mastic test should be employed for corroborative evidence. The technic described for the mastic test is that of Emanuel modified by Cutting. The technic follows:

A stock mastic solution is made by dissolving $10 \mathrm{gm}$. of gum mastic in 100 c.c. of absolute alcohol. The solution is filtered. This stock solution keeps indefinitely if well corked. To 2 c.c. of this solution 18 c.c. of absolute alcohol are added, and insufflated rapidly into 80 c.c. of distilled water, this makes an emulsion of mastic which is opalescent when held to the light. This solution can be used immediately or after several days; indeed, the reactions seem to be more casily read when a solution is employed which has stood for at least a few hours.

Next, a 1.25 per cent sodium chloride solution is made with distilled water, and to each 99 c.c. of this salt solution is added 1 c.c. of a 0.5 per cent solution of potassium carbonate made up with distilled water.

Then six small test tubes are placed in a rack. These tubes should have been washed thoroughly in tap water, then in denatured alcohol, to remove any old mastic adhering to the sides of the tubes, rinsed in distilled water and dried, conveniently in the hot air oven. To the first tube 1.5 c.e. of the combined salt and potassimm carbonate solutions are added, and to the others 1. c.e. each. Then 0.55 c.c. of spinal fluid is added to the first and after thorough 
mixing, 1 c.c. is transferred from the first to the second, 1 c.c. from the second to the third, and so on, the last cubic centimeter that remains over from the next to the last tube being thrown ont, and no spinal fluid being put in the control. Now to each tube, 1 c.c. of the mastic solution is added and stirred thoroughly with a glass rod, care being taken to wash the rod with distilled water before going to the next series. It is best to finish each group before beginning another.

The racks are set away, and in from twelve to twentyfour hours the end results can be read. If the racks are placed in an incubator at $37.5^{\circ} \mathrm{C}$, the precipitation is complete in fiom six to twelve hours.

\section{CYTOLOGIC EXAMINATION}

The examination of the cells in the cerebrospinal fluid is of extreme importance diagnostically and should be included in every routine examination of the fluid. There are essentially two methods of counting the cells; one is the sedimentation, or French method, and the other is the counting chamber method.

\section{The French Method of Cell Counting}

This method, originally described by Ravant, Sicard and Widal, is as follows: 3 to 4 c.c. of fluid is centrifuged for forty-five minutes. The fluid is then poured off and a few drops of the sediment are drawn up into a pipette of small caliber, and put on a glass slide, making a smear of uniform thickness. The stide is dried in the air, fixed in the flame, and stained with methyl blue or with Wriglit stain and examined under the microscope with the high power or oil immersion lens. The number in each field is now read. The results of this examination are recorded as follows: 


\section{Chamber Method of Cell Counting}

Either a special counting chamber for spinal fluid, such as the Fuchs-Rosenthal counting chamber, or the ordinary lencocyte chamber, such as the Thoma-Zeiss or Neubaner chamber may be used.

The Fuchs-Rosenthal chamber (Fig. 33) is larger than the ordinary lencocyte chamber, being $16 \mathrm{~mm}$. square and $0.2 \mathrm{~mm}$. deep, whereas the Thoma-Zeiss chamber is only 1 mm. square and $0.1 \mathrm{~mm}$. deep. (Fig. 34.)

The cells are counted in the following way hy the FuchsRosenthal method: the fluid is drawn up into a white blood pipette to mark 1.0 and then the staining fluid, consisting

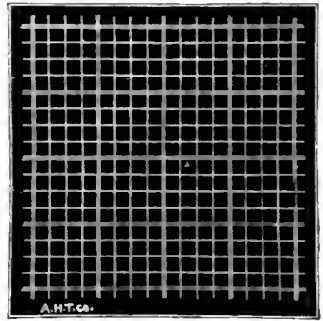

Fig. 33.-Fiuchs-Rosenthal chamber for counting cells in cerebrospinal fluid.

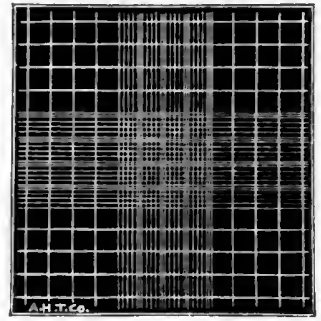

Fig. 34.-Neubauer blood counting chamber which may be used for cere. brospinal fluid.

of methyl violet $0.2 \mathrm{gm}$, glacial acetic 5 c.c. and water to 100 c.c. is drawn up to mark 11. The resulting number gives the cells contained in $16 / 5 \mathrm{~mm}$. The Fuchs-Rosenthal chamber also allows the differentiation of the different types of cells present in the fluid.

In using an ordinary blood counting chamber for counting the cells in cerebrospinal fluid any of the standard chambers answer the purpose quite well. The same solution used for staining the cells in the Fuchs-Rosenthal' chamber is also used here, namely, methyl violet $0.2 \mathrm{gm}$, glacial acetic 5 c.c. and water to 100 c.e. The methyl violet is drawn up into the pipette to mark 1.0 and the spinal fluid 
to mark 11. This gives a dilution of $1: 10$. Since the ruled surface of the blood counting chamber has an area of 9 square millimeters and the depth of the chamber is $1 / 10$ millimeter, the total count of the ruled surface will be the amount contained in the entire volume which is $9 / 10$ cubic millimeters. To obtain the number of cells in one cubic millimeter $1 / 9$ of the entire cell count has to be added to the number found. Since to ten parts of the spinal fluid, one part of counting fluid was added the result obtained corresponds to $\% / 10$ of the number of cells in a cubic nillimeter of pure spinal fluid. Therefore, in order to obtain the number of cells in one c.mm. of spinal fluid, we have to make allowance for this by adding $1 / 9$ to the result obtained. This gives the number of cells per cubic millimeter of undiluted cerebrospinal fluid.

Example: Let us suppose that the chamber contains 90 cells in its nine fields.

A counting chamber $\% 1 / 10$ c.mm. volume contains 90 cells.

Then 1c.mm. will contain $1 \%$ × 90 cells $=100$ cells.

In other words, 100 cells are contained in one cubic millimeter of space which contains nine parts of spinal fluid and one part of methyl violet. In ten parts of fluid, therefore, we will have 111 cells.

\section{Comparative Value of the Two Methods}

The centrifuge method of counting the number of cells in the spinal fluid is open to several rather serious objections. First of all the method is not accurate enough as it is not always easy to measure the exact amount of fluid put into the centrifuge tube. Moreover, the size of the drop taken from the sediment of the fluid can not possibly be the same at all times. Furthermore, the force of centrifugation and the rate of velocity of the centrifuge are important determining factors. Still another drawback is the fact that the centrifuge method requires a great amount of fluid for counting, more than can usually be spared. For precise results, I should therefore, recommend the use of the blood or fluid comnting chamber. However, when a rough estimate of the number of cells is all that is re- 
quired, the centrifuge method is perhaps the more convenient one to use. Another point in its favor is the fact that it enables one to study the type of the cell on one and the same slide.

There is one thing, however, that can not be emphasized too strongly and that is, that whatever method is employed, the examiner should thoroughly familiarize himself with it and should use it as a standard, so that he can easily detect eren a slight increase in the cells of the spinal fluid. Another thing to remember is that the cells should be counted immediately after withdrawal of the fluid from the body, as they undergo autolysis upon standing.

When the cerebrospinal fluid is blood stained, the specimen may still be utilized for cell counting, if only a rough count is desired. It is known that under normal conditions the blood contains one lymphocyte to three lencocytes. To obtain the number of lymphocytes, therefore, the white blood cells in the spinal fluid should be counted and the result divided by three.

\section{Type of Cells}

In doing a differential cell count, care must be taken to count only the white cells and not the red cells or the débris. When the fluid is turbid as in epidemic or in pneumococcus meningitis, a differential cell count may be made on the fluid directly without centrifugation. As a rule, however, it is best to centrifuge the fluid from fifteen to thirty minutes through about 1500 revolutions. If the fluid contains only a very small amount of protein, some egg albumin may be rubbed on the slide to prevent the smear from being washed off. The fluid may be stained with Wright's stain, or with other blood stains such as Jemner's, Leischman's, or eosin hematoxylin and the cells counted according to their type and the cell count expressed in percentages. As a rule, however, no special stain is needed for the differential cell count, for usu- 
ally the gram stain shows the cells quite well and also stains the organisms at the same time. If tuberculous meningitis is suspected, the special carbol fuchsin stain should be used, as it shows the tubercle bacilli and also stains the cells well.

\section{BACTERIOLOGIC}

One must be very careful in doing bacteriologic work on spinal fluid, for there are many technical factors that may interfere with the success of the work. Such factors may be wrong media, insufficient length of time for the organism to develop, contamination of the media, dirty slide, overheating of the slide, (protein particles often look like bacteria) and faulty stains. At times, I have found organisms in a spinal fluid smear done by a novice that did not belong to the spinal fluid, but were introduced while in the centrifuge tube, or were on the slide used for a urine examination.

\section{Culture Media}

One drop on a platinum needle or several drops are planted on a culture medium. The kind of media to plant the spinal fluid on depends on the type of organism looked for. Most organisms grow on plain agar. Meningococei have given some workers great difficulty in that they do not grow easily on ordinary media. I, however, have grown meningococei successfully on ascitic dextrose agar and also sheep blood agar. It is strongly advisable to implant every specimen of cerebrospinal fluid on several media, such as blood agar, ascitic dextrose agar, and glucose and agar. The culture should be examined microseopically after twenty-four hours' incubation, and also after fortyeight hours, as some organisms do not manifest their characteristies till after forty-eight hours of incubation.

In addition to the culture media, it is a good plan to put the spinal fluid left over in the test tube directly into 
the incubator and to examine it twelve to twenty-four hours later for organisms, as it has been found that some organisms, especially the meningococci, will show up well after the spinal fluid has been incubated for several hours.

\section{Direct Smear}

Several cubic centimeters of spinal fluid are centrifuged in a centrifuge tube for several minutes, the supernatent fluid is poured off and the sediment is put on a slide and stained. Where suppurative organisms are suspected it is best to stain with both methyl blue and gram stain. When tubercle bacilli are searched for, the fluid should be allowed to centrifuge at high speed for forty-five minutes to one hour and stained by the Ziehl-Neelsen method. If there is more than one tube of cerebrospinal fluid, it is advisable to examine the pellicle formed in the tube for tuberele bacilli. In my hands this has given good results. If the spinal fluid is very thick, the smear may be taken from the uncentrifuged spinal fluid.

\section{IMMUNOLOGIC}

Among the immunologic tests in routine cerebrospinal fluid examinations are agglutination tests for meningococci and pneumococci, precipitin tests of cerebrospinal fluid with antimeningococens serum, the neutralization test for anterior poliomyelitis, and the Wassermamn test. Two agglutination tests have been described for the meningococcus; the macroscopic and the microscopic.

\section{Macroscopic Method}

A polyvalent antimeningococeus serum which has been proved by appropriate tests to agglutinate established strains of meningococcus in dilutions from $1: 200$ to $1: 2000$ is used. 
A meningococcus culture, preferably only 24 hours old, grown on ascitic dextrose agar or on blood agar is washed down with 2 or 3 c.c. of an 0.8 per cent sterile salt solution; 0.2 c.c. of this meningococcus emulsion is added to a series of small test tubes each one containing 0.8 c.c. of various serum dilutions such as 1:10, 1:20, 1:40,1:80, 1:100, 1:500, $1: 1000,1: 2000$ strength. This is mixed and incubated overnight (15 to 20 hours) at $56^{\circ} \mathrm{C}$. Controls of meningococcus

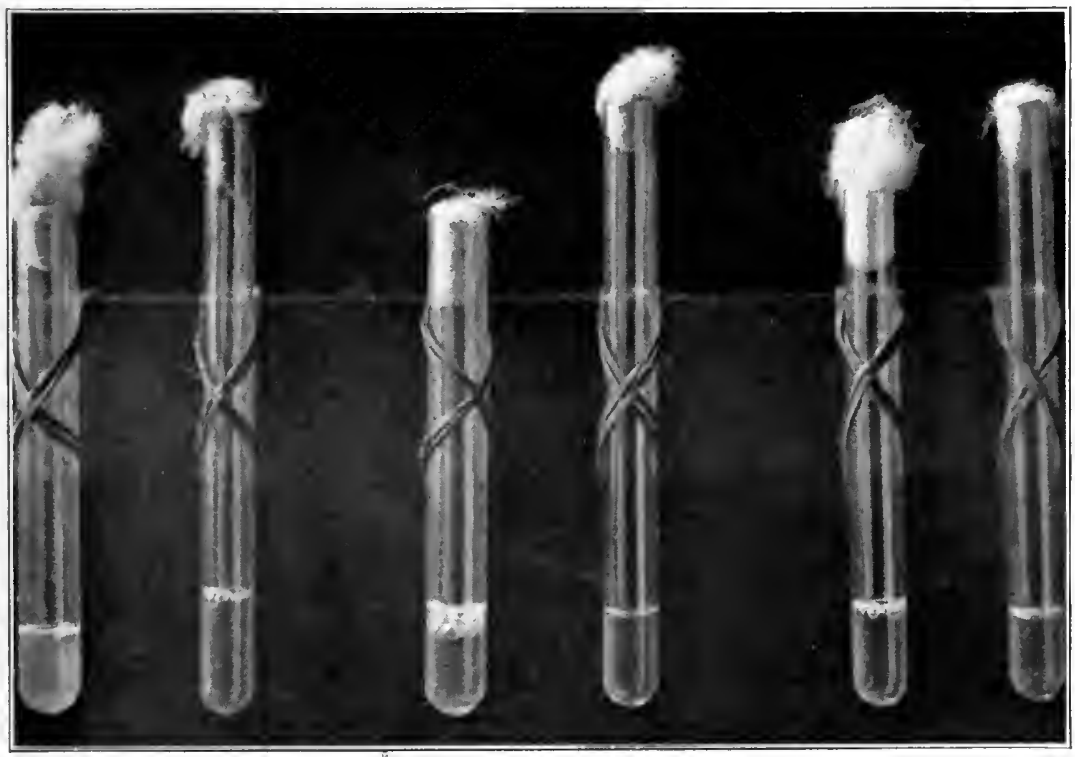

$A$. $B$. C. D. E. F.

Fig. 35.-Photograph showing agglutination of meningococci by the macroscopic method.

A. Fmulsion of meningococci $+1: 10$ dilution of antimeningococcus serum.

B. Control of emulsion of meningococci + salt solution.

C. Emulsion of meningococci $+1: 160$ dilution of antimeningococcus serum.

D. Control.

F. Finulsion: of meningococci $+1: 640$ dilution of antimeningococcus serum.

F. Control.

enuulsion added to 0.8 c.e. of salt solution are also incubated. If the culture in question is meningococcus, a flocculent precipitate will be seen in the tubes containing the bacterial emulsion and antineningoeoceus serum, the heaviness of the precipitate depending on the amount of dilution. The controls will be free from precipitate. A true menin- 


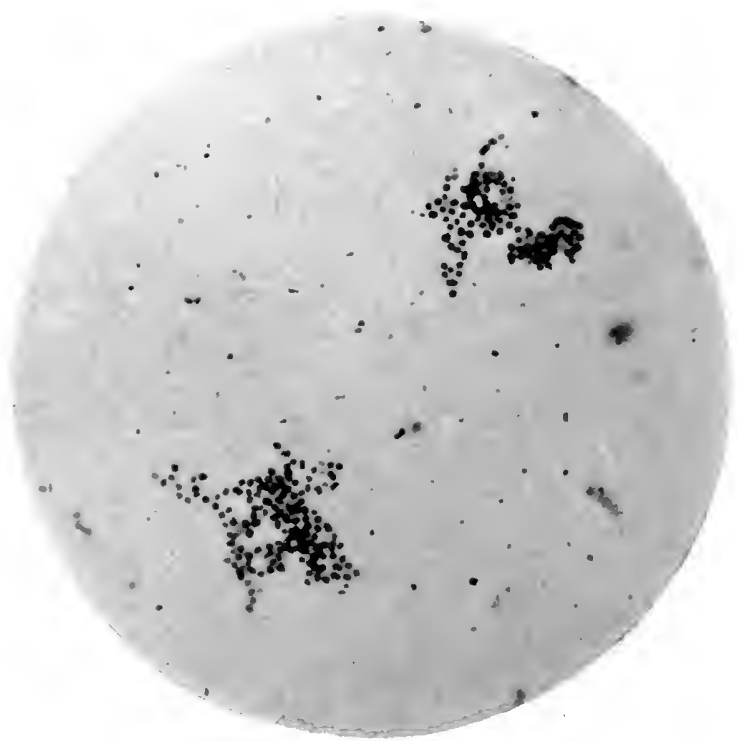

A. Agglutination by specific serum.

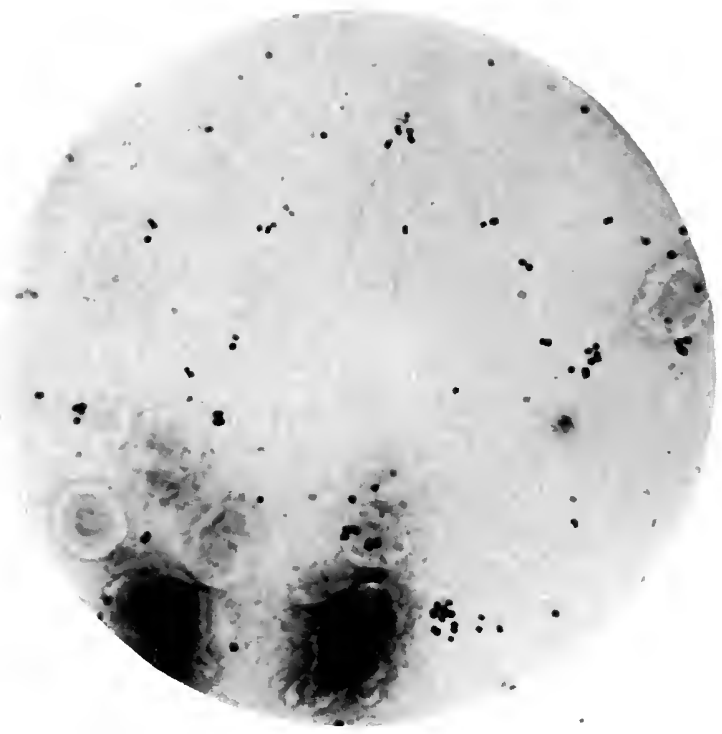

B. Absence of agglutination with normal horse serum.

Fig. 36.-Microscopic method of agghtinating meningococci. (Tumnicliff.) 
grococcus is completely agolutinated in $1: 200$ dilution of polyvalent serum. It is usually also agglutinated in higher dilutions (Fig. 35). The other gram-negative cocei are usually not agghtinated at all and never in greatre dilutions than 1:100. Micrococeus flavus sometimes agglutinates in polyvalent and monovalent moningococens serum in 1 :50 dilutions but may be differentiated from the meningococcus by its cultural properties.

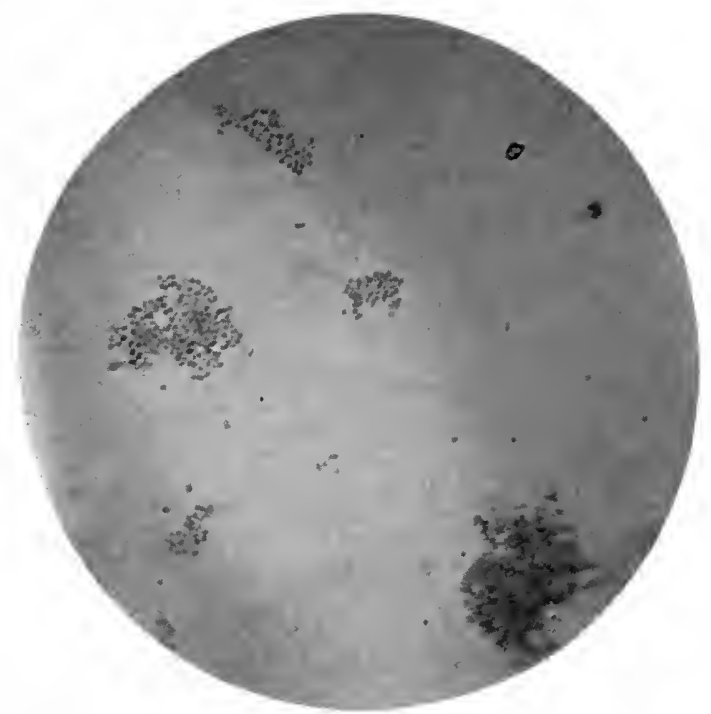

rig. 37.-Agglutination of meningococci by the microscopic method. (Magnification 800 diameters.)

\section{Microscopic Method}

A more rapid method than the macroscopic for the agglutination of meningorocei has been described by Tumnicliff. Fqual parts of antimeningococens serum, whole human blood in sodium citrate solution (one part of blood to 2 per cent sodium citrate in salt solution), and a suspension of organisms are incubated for ten minutes and then stained and examined. Normal horse serum with a suspension of organisms is used as control. In the mixture with normal horse sermm there is very little or no elump- 
ing of the meningococcus, while in the mixture containing antimeningococcus serum there is decided agglutination (Figs. 36 and 37). The suspension of the organisms is made by adding one or two colonies of the original culture to two or three drops of salt solution. One drop of serum is drawn up in a bent capillary tube, and the upper point marked, then an equal amount of citrated blood and later the suspension of the organisms are drawn up. The content of the pipette is now carefully mixed and heated for ten minutes at $36^{\circ} \mathrm{C}$, or left at room temperature for twenty minutes; after incubation the content is blown out on a glass slide, spread with cigarette paper and stained unfixed with carbol thionin or fixed with heat and stained with methylene blue.

Either of the agghtutination tests gives good results. I would advise that whenever possible both the macroscopic and microscopic agghtutination shonld be carried out; when the time is limited the microscopic method can be depended upon.

Agglutination of pneumococei is utilized to determine the type of the organism, Type I, Type II and Type III, antipneumococcus serum being used for that purpose.

\section{Precipitation of Cerebrospinal Fluid with Antimeningo- coccus Serum}

According to Vincent and Ballot normal cerebrospinal fluid does not form any precipitate with antimeningococeus serum, while fluid from meningococcus meningitis is precipitated, when incubated with antimeningococeus serum.

The technic of the test is as follows: The spinal fluid is centrifuged till it becomes clear. Two to five drops of antimeningococeus serum are then added to 50 and 100 drops of the clear spinal fluid. The specimens are inculbated at $50^{\circ}$ C. for eight to fourteen hours. If the fluid is one of meningococcus meningitis, the mixture becomes turbid. A tube 
containing spinal fluid to which no antimeningococcus serum has been added is used as a control.

While other workers have confirmed the observation of Vincent and Ballot, it has been pointed out that at times fluids from other types of meningitis will show the same reaction with antimeningococeus sermu. One of the difficulties of the test is that often it is impossible to clarify the spinal fluid of meningococeus meningitis even after ecmtrifugation for a long period. This test should therefore be performed only when there is sufficient fluid left over from other more necessary tests.

\section{Guinea Pig Inoculation}

It is often necessary to employ the inoculation test to decide whether or not the process is tuberculous in nature.

Five to 10 c.e. of cerebrospinal fluid is injected into the groin of a guinea pig. A month later $0.1 \mathrm{mg}$. of Old Tuberculin is injected into the axilla of the pig. If the meningitis is tuberculous in nature the pig usually dies the morning after the injection of the tuberculin. Tubercles are found postmortem in both the spleen and the inguinal glands.

\section{Neutralization Test}

Some authors employ the neutralization test in poliomyelitis. The technic of this test is as follows: A fatal dose of active virus is mixed with the suspected fluid obtained during the stage of recovery. This mixture is incubated and injected intracerebrally into a monkey. Failure of the disease to develop in the monkey indicates neutralization of the virus.

\section{The Wassermann Reaction}

It is impossible to describe all the details of the Wassermann reaction in a small volume. I shall therefore, limit myself here to only those factors in the Wassermamn 
reaction that lave a special bearing on the subject of cerebrospinal fluid.

Principle.-The blood serum and cerebrospinal fluid of persons affected with syphilis contains syphilitic antibodies. The presence or absence of syphilitic antibodies in the system is demonstrated by the complement-fixation test, or the Wassermann test as it is more commonly known. The substances necessary for complement fixation are: antigen, fluid to be tested, and complement. An antigen is a substance which, when injected into an animal, causes the organism to react by the formation of antibody. The fluid to be tested supplies, if positive, the syphilitic antibody. Complement is a substance present in fresh blood serum which is necessary for the binding of antigen to antibody. The Wassermann reaction is called a complementfixation test although it is not really a complement fixation in the strictest sense of the term muless a suspension of spirochetes is used as an antigen.

Different kinds of antigen are used for the Wassermann test, (a) an aqueons extract of syphilitic liver (original method); (b) an alcoholic extract of syphilitic liver; (c) an alcoholic extract of normal liver; (d) an alcoholic extract of heart (either human or beef) reinforced with cholesterin; (e) ether soluble, acetone insoluble extract of heart. At present alcoholic extracts of heart are generally used as antigen.

The complement consists of blood serum of healthy guinea pigs diluted with sterile normal salt solution.

The amboceptor (antisheep antibody) is contained in the serum of rabbits immunized with washed sheep corpuscles.

If the cerebrospinal fluid contains syphilitic antibodies, the antigen combines with the syphilitic antibody and the complement, so that when antisheep amboceptor and sheep cells are added, the complement is alleady bound and there- 
fore hemolysis can not take place. If there are no syphilitic antibodies in the fluid, the complement unites with the antisheep antibody or amboceptor and the sheep corpuscles and produces hemolysis. Table XXXVIII shows the process in the Wassermann reaction of both syphilitic and nonsyphilitic cases.

TABLE XXXVIII

\begin{tabular}{|c|c|}
\hline POSITIVE & NEGATIVE \\
\hline $\begin{array}{l}\text { I. Antigen } \\
\begin{array}{l}+ \\
\text { Syphilitic Antibody } \\
+ \\
\text { Complement }\end{array}\end{array}$ & I. Antigen \\
\hline $\begin{array}{c}\text { II. Antibody or Antisheep } \\
\text { Amboceptor } \\
+ \\
\text { Sheep Corpuseles }\end{array}$ & $\begin{array}{l}\text { II. Complement } \\
+ \\
\text { Antibody or Antisheep } \\
\text { Amboceptor } \\
+ \\
\text { Sheep Corpuscles }\end{array}$ \\
\hline
\end{tabular}

The amount of fluid used for the Wassermann test is not always the same. Some use as little as 0.2 c.c. of fluid, whereas others, notably Thomson, use as much as 1.0 and even 1.2 c.c. It has been found that the small amounts do not give positive results as frequently as the larger. This fact, I believe, explains the great number of negative Wassermann reactions on cerebrospinal fluid by the older authors who used very small amounts for the tests. On the other hand, large amounts of cerebrospinal fhuid such as Thomson advises are likely to be anticomplementary. Schottmuiller's suggestion that various amounts of the fluid be used for the same test, is, I believe the most commendable plan.

Schottmüller advises the use of a series of Wassermann tests with fluid varying in amount from 0.2 to 1 c.e. and with dilutions of salt solution. 
TABLE XXXIX

\begin{tabular}{lccccc}
\hline & TUBE 1 & TUBE 2 & TUBE 3 & TUBE 4 & TUBE 5 \\
\hline Cerebrospinal Fluid & c.c. & e.c. & c.e. & c.c. & c.c. \\
NaCl Solution & 0.2 & 0.4 & 0.6 & 0.8 & 1.0 \\
Antigen & 0.8 & 0.6 & 0.4 & 0.2 & \\
Complement & 1.0 & 1.0 & 1.0 & 1.0 & 1.0 \\
Amboceptor plus colpuscles 2.0 & 1.0 & 1.0 & 1.0 & 1.0 & 1.0 \\
\hline
\end{tabular}

It is advisable to carry the amounts of cerebrospinal fluid even further than is indicated in Table XXXLX. It is best to make the Wassermamn test with freshly drawn cerebrospinal fluid. If the test can not be made immediately after the withdrawal of fluid, it should be put away in the ice box without preservative. The cerebrospinal fluid is

\section{TABLE XL}

Examination of Cerebrospinal Fluid for Diagnostic Purposes

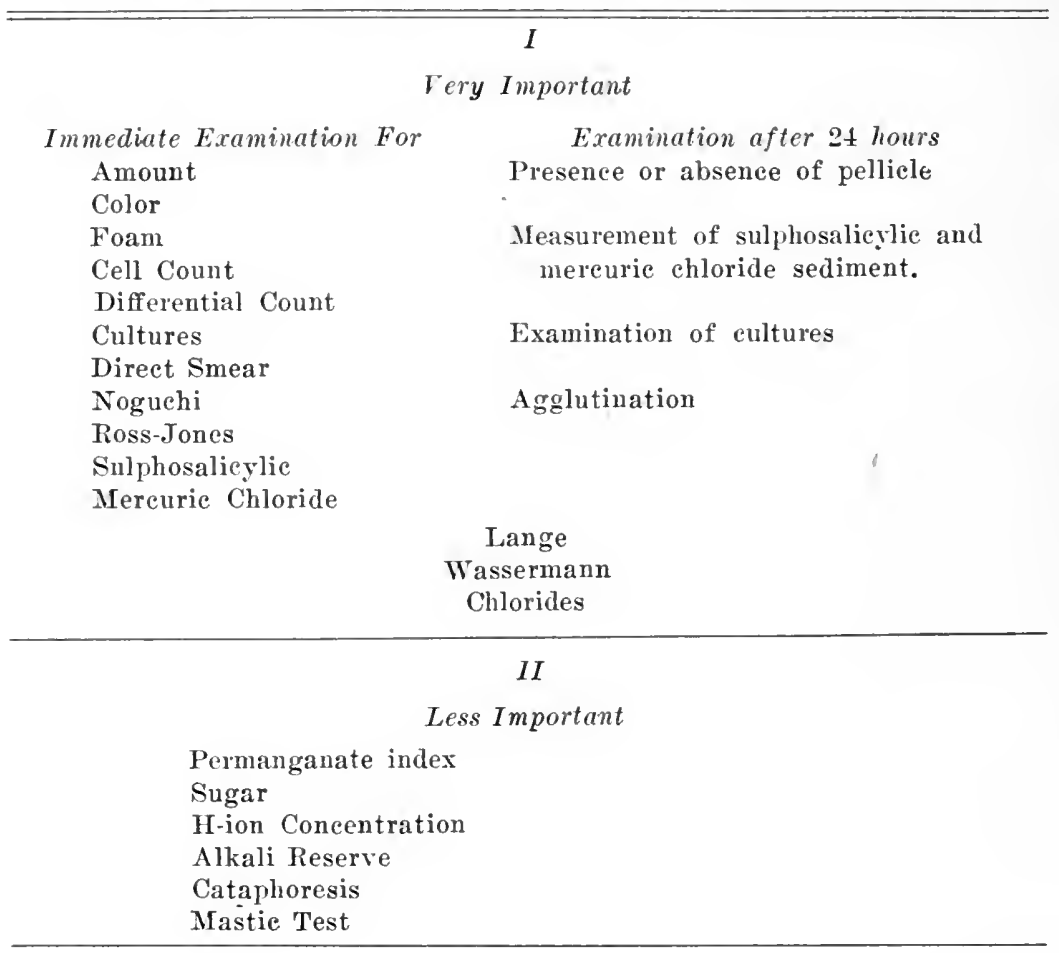


not inactivated. Preliminary titrations must be made on antigen, complement and amboceptor before the test is set up. The proper dose of antigen I believe to be one-fourth of anticomplementary unit and the proper dose of complement and amboceptor to be two units each. Control tubes of the cerebrospinal fluid should be set up with the test.

The cerebrospinal fluid, salt solution, antigen and complement are incubated for one hour at $37.5^{\circ} \mathrm{C}$. Then the antisheep amboceptor and the sheep corpuscles are added and the solution is returned to the incubator where it is allowed to remain from 30 minutes to 2 hours. At the expiration of this time, it is taken out and examined. If hemolysis is present the test is negative; if there is an inhibition of hemolysis, the test is positive.

\section{Bibliography}

Alzheimer: Einige Methoden zur Fixierung der zelligen Elemente der Cerebrospinalflïssigkeit, Centralbl. f. Nervenh. u. Psychiat., 1907, xxx, 449.

Andernach: Beiträge zur Untersuchung des Liquor eerebrospinalis mit besonderer Berücksichtigung der zelligen Elemente, Arch. f. Psychiat., 1910, xlvii, 806.

Black, Rosenberg and MeBride: The Colloidal Gold Test, Jour. Am. Med. Assn., 1917, lxix, 1855.

Blumenthal: Serodiagnose der Syphilis, Dermat. Ztschr., 1910, xvii, 1.

Boveri: Di una nuova reazione del liquido eefalo rachidano, Riv. di patol. nerv., 1914, xix, 280.

Cutting: A New Mastic Test for the Spinal Fluid, Jour. Am. Med. Assn., 1917, lxviii, 1810.

Emanuel: Eine neue Reaktion zur Untersuchung des Liquor Cerebrospinalis, Berl. klin. Wehnschr., 1915., lii, 792.

Epstein: An Accurate Microchemical Method of Estimating Sugar in the Blood, Jour. Am. Med. Assn., 1914, xiii, 1667.

Fuchs and Rosenthal: Physikalisehe, ehemische $u$. anderwertige Untersuehungen der Cerebrospinalflüssigkeit, Wiener, med. Presse, 1904, xlvii, 44.

Grulee and Moody: Lange's Colloidal Gold Chlorid Test on the Cerebrospinal Fluid in Congenital Syphilis, Jour. Am. Med. Assn., 1913, Ixi, 13.

Lange: Die Ausflockung kolloidalen Goldes durch Zerebrospinalflüssigkeit bei luetisehen Affektionen des Zentrahervensystems, Ztsehr. f. Chemotherap., 1913, i, 44.

Lowrey: Cerebrospinal Fluid Tests, Especially the Gold Reaction in Psychiatric Diagnosis, Jonr. Nerv. and Ment. Jis., 1917, xlvi, 186.

The Mastiche and Potassium Permanganate Tests Applied to the Cerebrospinal Fluid of the Insane, Boston Med. and Surg. Jour., 1917, elxxvii, 115.

Mann and van Saun: Value of Chemical Tests on the Serums and Spinal Fluids of Syphitities, New York Med. Jour., 1918, evii, 783. 
Miller, Brush, Hammers and Felton: A Further Study of the Diagnostic Value of the Colloidal Gold Reaction, Together with a Method for the Preparation of the Reagent, Bull. Johns Hopkins Hosp., 1915, xxvi, 391.

Noguchi: The Relation of Protein, Lipoids and Salts to the Wassermann Reaction, Jour. Exper. Med., 1909, xi, 84.

Eine für die Praxis geeignete leicht ausführbare Methode der Serumdiagnose bei Syphilis, München. ned. Wehnsehr., 1909, lvi, 494.

Sernn Diagnosis of Syphilis, J. B. Lippineott Co., 1910.

Nonne: Weitere Erfahrungen (Bestitigungen und Modifikationen) über die Bedeutung der 4 Reaktionen (Pleocytose, Phase I. Wassermam Reaktion im Serum und im Liquor spinalis) für die Diagnose der syphilidogenen IIim- und Rückenmarkskrankheiten, Dritte Jahresvers. d. Ges. deutseher Nervenärzte, Ref. x. Ztsehr. f. Nervenh., 1910, xxxviii, 291-307.

Nonne and Apelt: Über fraktionierte Eiweissausfallung in der Spinalflüssigkeit, Areh. f. Psyehiat., 1907, xliii, 433.

Pandy: ¿̈ber die neue Eiweissprobe für die Zerebrospinalflüssigkeit, Neurol. Zentralbl., 1910, xxix, 915.

Redlich, Potzl, and Hess: Untersuchungen üher das Verlalten des Liquor cerebrospinalis bei der Epilepsie, Ztseh. f. ges. Neurol. u. Psychiat., 1910, ii, 715 .

Ross and Jones: On the Use of Certain New Chemical Tests in the Diagnosis of General Paralysis and Tahes, Brit. Med. Jour., 1909, i, 1111.

Seelman: Simple Test for Estimating Chlorides in the Urine Founded on Volhard's Method, Jour. Lab. and Clin. Med., 1916, i, 444.

Swift and Ellis: Method of Cell Counting in Cerebrospinal Fluid, Jour. Exper. Ned., 1913, xviii, 164.

Szeesi: Zur Technik der Chen. und Zytolog. Untersuchung der Lumbalfiüssigkeit, Monatsehr. f. Psychiat. u. Neurol., 1910, xxvi:, 152. 


\section{CEREBROSPINAL FLUID IN VARIOUS DISEASES}

\section{Uremia}

In uremia the fluid is often increased both in anount and pressure, especially if there are convulsions. The cells may or may not be increased in number. The chlorides are often increased to 0.8 or $0.85 \mathrm{gm}$. per 100 c.e. of fluid. The urea is greatly increased in anomnt. According to Lockemann and Füth the lactic acid in the fluid is also increased in amount.

\section{Diabetes Mellitus}

The cerebrospinal fluid is normal in appearance and pressure in cases of diabetes mellitus. It is chemically negative in all respects but in its sugar content, which is greatly in excess of normal. Foster found the sugar in the fluid of 12 cases of diabetes to vary between 0.5 per cent and 3 per cent. My highest finding was 0.38 per cent. In one case I found the sugar content in the cerebrospinal fluid to be even higher than that of the blood. Acetone and diacetic acid may also be found in large amounts in the cerebrospinal fluid of patients suffering with diabetes mellitus.

\section{Chorea}

Dupre and Damus found a distinct lymphocytosis in the cerebrospinal fluid of a chorea in a boy of eighteen. Babonneix found a lymphocytosis in two of five cases. Thonlas and Tinel found a distinct lymphocytosis in a girl of thirteen, suffering from chorea. They found a similar condition in two of four other patients exannined a few montlis later. Gatow-Gatorski found a hypertension in one case of chorea. 
Richardier, Lemaire and Sourdel found a lymphocytosis in twelve out of fourteen cases and hypertension in ten. In three cases, symptoms were somewhat relieved by puncture. A number of French observers found a positive Wassermann in chorea and because of this finding, argued in favor of the specific nature of chorea. Leopold and Bernhard found the cerebrospinal fluid in chorea to be normal in the chemical and eytologic tests. In the cases of chorea that came under my observation, the cerebrospinal fluid was normal in all respects, including the Wassermann. The cerebrospinal fluid in Huntington's chorea or hereditary chorea is normal in all respects. The rarious experiences cited above incline me to the belief that the examination of spinal fluid is of no special value in the diagnosis' of chorea.

\section{Epilepsy}

During an epileptic attack the cerebrospinal fluid is increased both in amount and in pressure. During the intervals between attacks, both the amount and pressure of the fluid may or may not be increased. In epilepsy due to cerebrospinal lues, the cells and globulin content are increased; in idiopathic epilepsy, both the cells and the globulin content are normal. The same is true of the Wassermann reaction.

\section{Mongolian Idiocy}

In Mongolian idiocy the cerebrospinal fluid is often negative physically, chemically and bacteriologically. Stevenson found the fluid from a large number of cases to give a typical lnetic gold chloride curve. Some of the cases examined by me gave positive Wassermann and Lange tests; many of them, however, gave negative tests. I, therefore, do not subscribe to the view that all cases of Mongolian idiocy have a luetic origin. There are some that are luetic by coincidence only. 


\section{Psychoses}

In psychosis the fluid is not uniform. In alcoholic psychosis the quantity of fluid that can be removed in one sitting is greatly increased, it often being possible to remove as much as 30 to 40 c.c. easily. The pressure is greatly increased in this type of psychosis, running, as a rule, from 150 to $300 \mathrm{~mm}$. of water in height. T'The fluid is clear and colorless; the protein is not increased, and the cells are usually normal both in number and type, although occasionally I have noticed an increase in the cell count ranging from 26 to 30 cells per cubic millimeter.

A number of authors who have been able to detect the presence of alcohol in the cerebrospinal fluid of alcoholic psychosis, suggest that the test for alcohol be used for diagnostic purposes.

Dementia precox gives a normal fluid as a rule. Rarely is the pressure increased. Paranoia also shows no deviation from the normal. The fluid in general paresis is not constant. In the majority of cases the fluid is increased in amount and pressure; the cell count is high, 30 to 40 per cubic millimeter; both the globulin and the Wassermann tests are positive. In a small percentage of cases, all the findings are negative with the exception of increase in amount and pressure of the fluid.

\section{Lues}

The findings in the cerebrospinal fluid in acquired lues depend on whether or not the nervous system is involved. If there is no involvement the fluid is negative, including the Wassermann test. If there is involvement there is an increase in the amount of the fluid, in the content of the protein, and in the number of the cells in the fluid, the cells being principally lymphocytes. The Wassermann is also positive.

Nonne speaks of four reactions in connection with syphilis of the nervous system: positive Wassermann reaction 
of the blood, increased globulin, lymphoeytosis and positive Wassermann reatction of the cerebrospinal fluid. Nomne's results may be smmmarized in Table XLI.

TABLE XLI

\begin{tabular}{|c|c|c|c|c|}
\hline & $\begin{array}{l}\text { WASSERMANN } \\
\text { TEST IN BLOOD }\end{array}$ & PHASE I & $\begin{array}{l}\text { LYMPHO- } \\
\text { CYTOSIS }\end{array}$ & WASSERMANX TEST IN \\
\hline General & $100 \%$ & $9 \overline{-100 \%}$ & $95 \%$ & $100 \%$ posit \\
\hline & Positive & Positive & & $\begin{array}{l}\text { quantities of fluid are } \\
\text { userl. }\end{array}$ \\
\hline $\begin{array}{l}\text { Tabes } \\
\text { without } \\
\text { paresis }\end{array}$ & $\begin{array}{l}60-70 \% \\
\text { Positive }\end{array}$ & $\begin{array}{l}85-90 \% \\
\text { Positive }\end{array}$ & $90 \%$ & $\begin{array}{l}100 \% \text { positive if large } \\
\text { quantities of fluid are } \\
\text { used. }\end{array}$ \\
\hline $\begin{array}{l}\text { Cerebro- } \\
\text { spinal } \\
\text { lues }\end{array}$ & $\begin{array}{l}\text { S0-90\% } \\
\text { Positive }\end{array}$ & & $100 \%$ & $\begin{array}{l}100 \% \text { positive if large } \\
\text { quantities of fluid are } \\
\text { used. }\end{array}$ \\
\hline
\end{tabular}

In syphilis of the nervous system the gold chloride test gives a positive reaction in the syphilitic zone, the reaction varying witl the type of the disease. Tn rerebrospinal lues the discoloration is in Tubes 1, 2, 3, 4. 5, and 6; (Fig. 38 ) in tabes the riscoloration is inconstant, but is nsually in Tubes 2, 3, 4, and 5 and sometimes in 6. (Figs. 39 and 41.) In paresis, the discoloration is nsually in the first six tubes and sometimes also in the seventh and eighth. (Figs. 40 and 42.)

TABLE XIII

\begin{tabular}{|c|c|c|c|c|c|c|}
\hline & \multicolumn{2}{|c|}{$\begin{array}{l}\text { GENERAL } \\
\text { PARALYSIS }\end{array}$} & \multicolumn{2}{|c|}{ TABES } & \multicolumn{2}{|c|}{$\begin{array}{c}\text { CEIREIRROSPINAL } \\
\text { SYPIILIS }\end{array}$} \\
\hline & $\begin{array}{l}\text { Num- } \\
\text { ber of } \\
\text { cases }\end{array}$ & $\%$ & $\begin{array}{l}\text { Num- } \\
\text { ber of } \\
\text { cases }\end{array}$ & $\%$ & $\begin{array}{l}\text { Jum- } \\
\text { ber of } \\
\text { cases }\end{array}$ & $\%$ \\
\hline 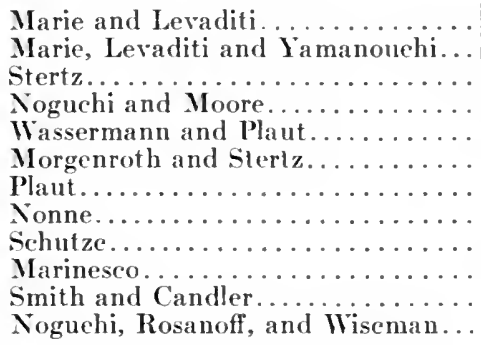 & $\begin{array}{r}39 \\
30 \\
45 \\
60 \\
41 \\
8 \\
54 \\
\vdots \\
35 \\
64 \\
56\end{array}$ & $\begin{array}{l}73 \\
93 \\
88.8 \\
73 \\
88 \\
100 \\
90 \\
90 \\
94 \\
92.1 \\
8 \% .5\end{array}$ & $\begin{array}{r}9 \\
5 \\
11\end{array}$ & $\begin{array}{l}66.6 \\
60 \\
54.5\end{array}$ & $\begin{array}{r}+ \\
16\end{array}$ & $\begin{array}{r}0 \\
50 \\
\\
0 \\
25\end{array}$ \\
\hline 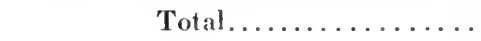 & 432 & 90 & 52 & 56.2 & 34 & 19 \\
\hline
\end{tabular}




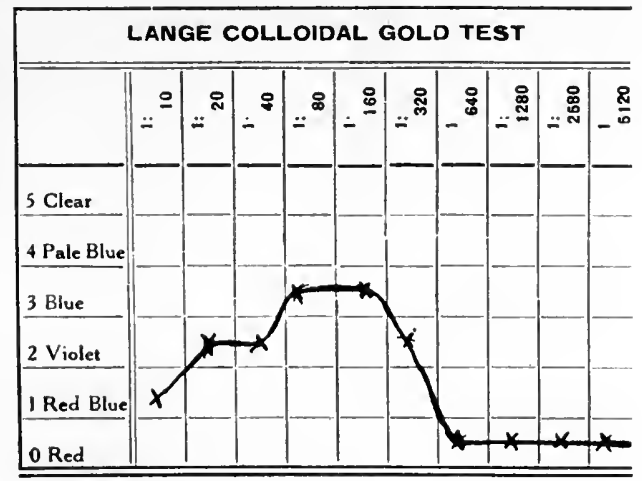

Fig. 38. - Case of cerebrospinal lues. Wassermann $t+++$.

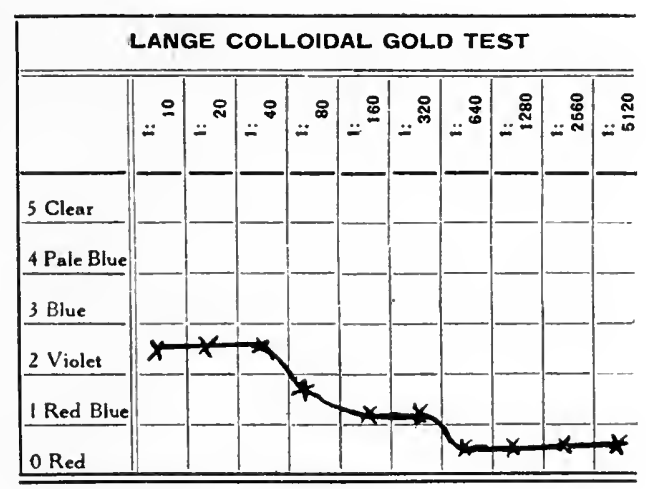

Fig. 39.-Case of tabes.

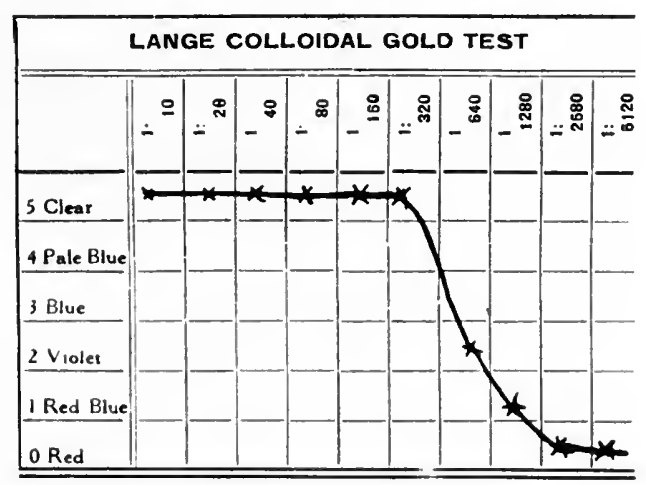

lïig. 40.-Case of general paresis. Wassermann +++ . 
The incidence of positive Wasserman reaction in the cerebrospinal fluid of lues is seen from Table XLII of Noguchi.

\section{Hydrocephalus}

As was pointed out in the chapter on normal cerebrospinal fluirl, the older writers considered the cerebrospinal fluid of hydrocephalus as normal fluid. Recent investigations have corroborated the truth of this observation. With the exception of the increase in the amount of the cerebrospinal fluid, the fluid of lydrocephalus shows no chemical, physicochemical or bacteriologic changes of any kind. Only infrequently does one find an increase in the protein content of hydrocephalic fluid. The amount of fluid which can be withdrawn from the subarachnoid space depends on the form of the hydrocephalus, whether it is internal or external. If the foramina of Magendie and Tuschka are blocked, very little fluid may be obtained by lumbar puncture. If the communication is open a great deal of fluid may be obtained by lumbar puncture. The pressure also depends on the amount of cerebrospinal fluid in the subarachnoid of the cord, being greatly increased where there is free communication.

\section{Spina Bifida}

The fluid is usually increased in amount in this condition, as is the protein.

\section{Hemorrhage of the Brain}

Cerebrospinal fluid removed soon after the hemorrhage occurs is bright red in color due to the admixture of the blood; and contains many red and white blood cells. As time progresses the cerebrospinal fluid becomes more yellow in color and the red cells become less in number. The amount of fluid, as a rule, is not increased. The protein is increased due to the addition of the protein from the blood. All other tests are negative. 



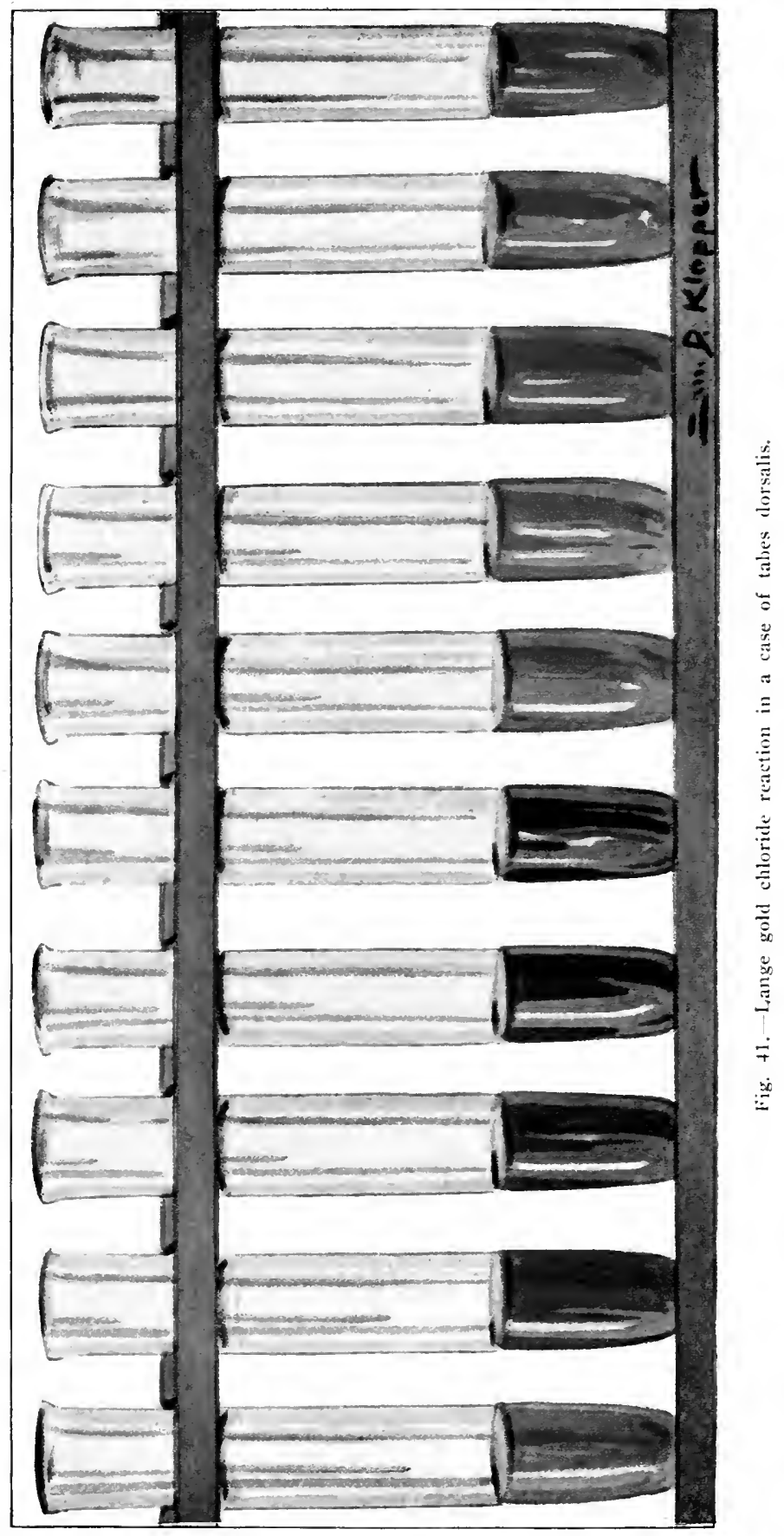




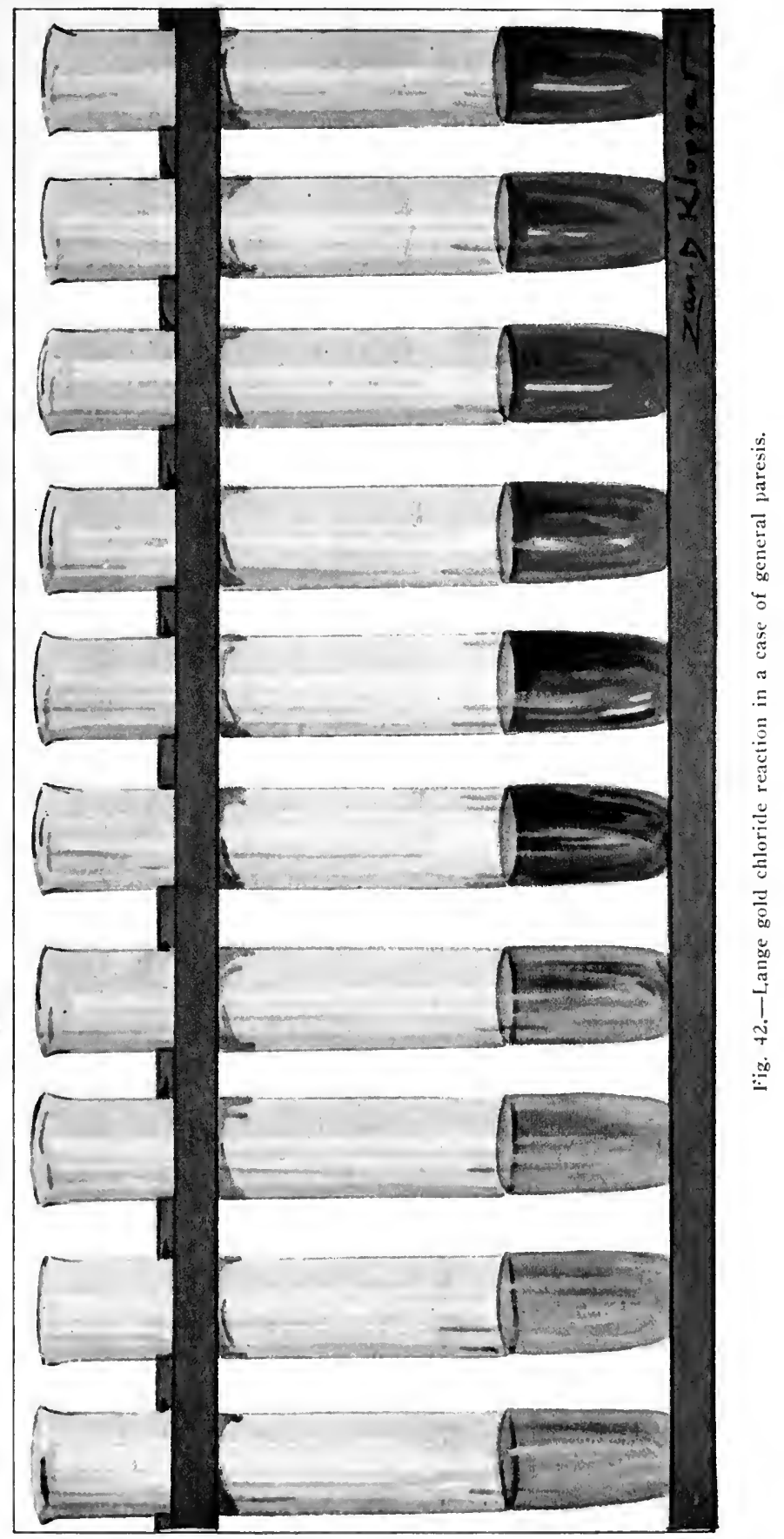




\section{Tumors of the Brain}

In tumors of the brain, the amount of cerebrospinal fluid may or may not be increased. The protein is usually not increased. Occasionally one finds an increase in the number of the cells, all of which are lymphocytes.

\section{Compression of the Cord}

Compression of the spinal cord gives rise to a number of manifestations of the cerebrospinal fluid. In tumors of the cauda equina and conus medullaris the Froin's syndrome usually makes its appearance. The syndrome shows the following characteristics: (1) xanthochromia or yellowish discoloration of the cerebrospinal fluid; (2) massive coagulation of the fluid; (3) an increased number of lymphocytes.

In tumors situated at higher levels of the cord, there is an excess of globulin present, but no increase of the cells. There may or may not be a yellowish discoloration of the fluid. In extramedullary compression of the cord there is usually a yellow discoloration of the fluid and an increase in the globulin, but no increase in the cells. Discoloration of the fluid alone, does not indicate compression of the cord, as this condition may be due to the presence of an old hemorrhage of the brain, or even to a puncture of the plexus of veins surrounding the cord.

\section{Encephalitis}

It is difficult to establish a diagnosis of encephalitis during life. After death encephalitis is seen as a feature of poliomyelitis, of meningitis, and of hydrocephalus. The cerebrospinal fluid in encephalitis, therefore, responds to the condition it accompanies. In poliomyelitis the fluid shows the changes of this discase; in meningitis it gives the reactions typical of the organism causing the infection. In encephalitis following acute infectious diseases, such as 
pertussis and measles, the cerebrospinal fluid is increased in amount and in pressure. The cells are either normal or slightly increased in number. The globulins are not increased, as a rule. In the recent epidenic of encephalitis lethargica the cerebrospinal fluid was colorless and showed a slight increase in the cell count and in the globulin. content.

\section{Meningism}

In many infectious diseases, notably, pneumonia and grippe and cases of otitis media and also in some cases of intestinal intoxication, there are often symptoms of cerebral irritation, simulating a meningitis, although no bacteria are found in the fluid and no meningeal exudate makes its appearance. To cases of this character, E. Dupré has given the name of meningism. The fluid in these conditions is generally increased in amount, sometimes even to the same extent as in a severe case of meningitis. The pressure of the fluid is also higher than normal. The color, however, is unclianged and the number of cells is increased only slightly or not at all. The globulin as well as the bacteriologic tests are usually negative. Only occasionally is there an increase in the globulin and in the cells. Caution, however, must be exereised not to make a premature diagnosis of meningism in all instances of negative findings of the fluid, for it frequently happens that eases of tuberculous meningitis and poliomyelitis in the early stages of the discase, give no other changes in the cerebrospinal fluid but an increase in the amount of the fluid.

\section{Tuberculous Meningitis}

The amount of fluid in tuberculous meningitis varies with the stage of the disease, being greater in the initial than in the paralytic stage. The pressure at the onset of the disease is very high, ranging between 300 and 700 $\mathrm{mm}$. water in height. The pressure remains high during 
the irritative stage but decreases during the stage of coma. The fluid is usually clear and transparent throughout the disease, although occasionally it becomes opalescent; it shows a heary foam on shaking. On standing from one hour to an entire day a pellicle forms, the pellicle being generally suspended in the center with processes projecting from its sides. There is an increase in the number' of cells which range from 30 to 150 per c.mm., most of them being small lymphocytes, although early in the disease there may be a preponderance of polymorphonurear lencocytes. The protein in the fluid is also greatly increased in amount. The albumin content ranges between 0.1 and 0.2 per 100 c.c. in adults. Fibrin and fibrinogen ale present in small amounts as is indicated by the presence of the pellicle in the fluid. Albuniose and peptone are absent, as a rule, as is also mucin.

The fluid of tuberculous meningitis also shows other variations from normal. The permanganate index is above 2 as compared with the index in nommeningitic fluid which is below 2. The chlorides are lessened in tuberculous meningitis, usually ruming below 0.6 gm. per 100 c.c. and sometimes falling as low as 0.5 gm. per 100 c.c. The sugar content varies, sometimes equaling the amount in normal fhid and sometimes falling below that of normal. As a rule, however, the sugar content ranges between 0.5 gin. and 0.6 sm. per 100 c.c. Plosphates, according to Apelt and Schumm, are present in amounts varying between 0.0034 and 0.0049 per cent.

The pliysicochemical constants also show a deviation from normal. The average density is given as 1.002, althongh in my cascs, I found it to vary botween 1.00626 and 1.00693 .

The viseosity varies between 1.0693 and 1.0694 . The conductivity is given by Fuchs and Rosenthal as ranging from 0.097 and 0.0225 , with an average of 0.0127 . The freezing point is usually lowered ruming between 0.45 and 0.55 . 
The $\mathrm{H}$-ion concentration averages a $\mathrm{P}_{\mathrm{H}}$ of from 7.4 to 7.6 immediately after the removal of the fluid from the body, with an increase in the alkalinity upon standing, so that one-half hour after withdrawal the $\mathrm{P}_{\mathrm{H}}$ of the fluid becomes 7.7 or 7.8. Twenty-four hours after withdrawal the $\mathrm{P}_{\mathrm{H}}$

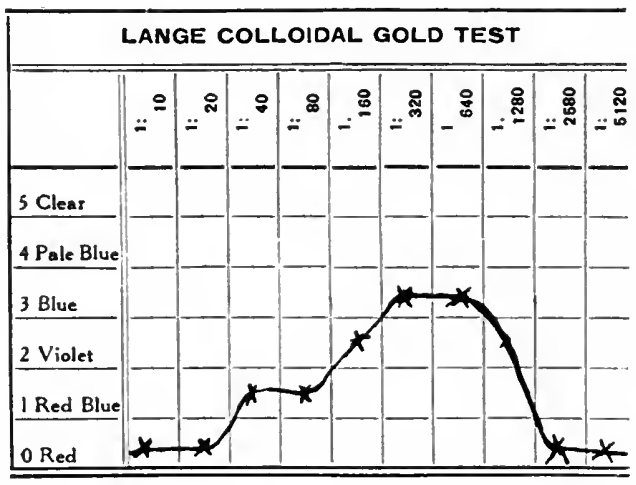

Fig. +3-A.-Case of tuberculous meningitis.

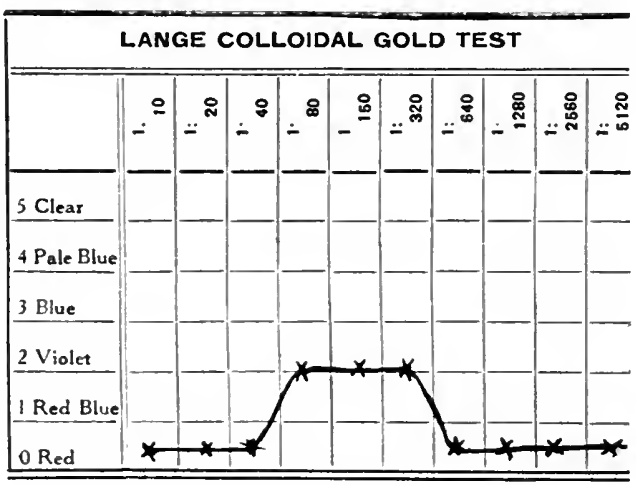

Fig. +3-B,-Case of tuberculous meningitis.

becomes 8.1, 8.2 or even higher. The alkali reserve runs parallel with the $\mathrm{H}$-ion concentration.

The gold chloride reactions give a discoloration corresponding to Tubes 5,6 , and 7 , sometimes to Tubes 7,8 , or 9 . (Figs. 43 and 44.) The ninhydrin test shows a discoloration with the fluid of tuberculous meningitis. 


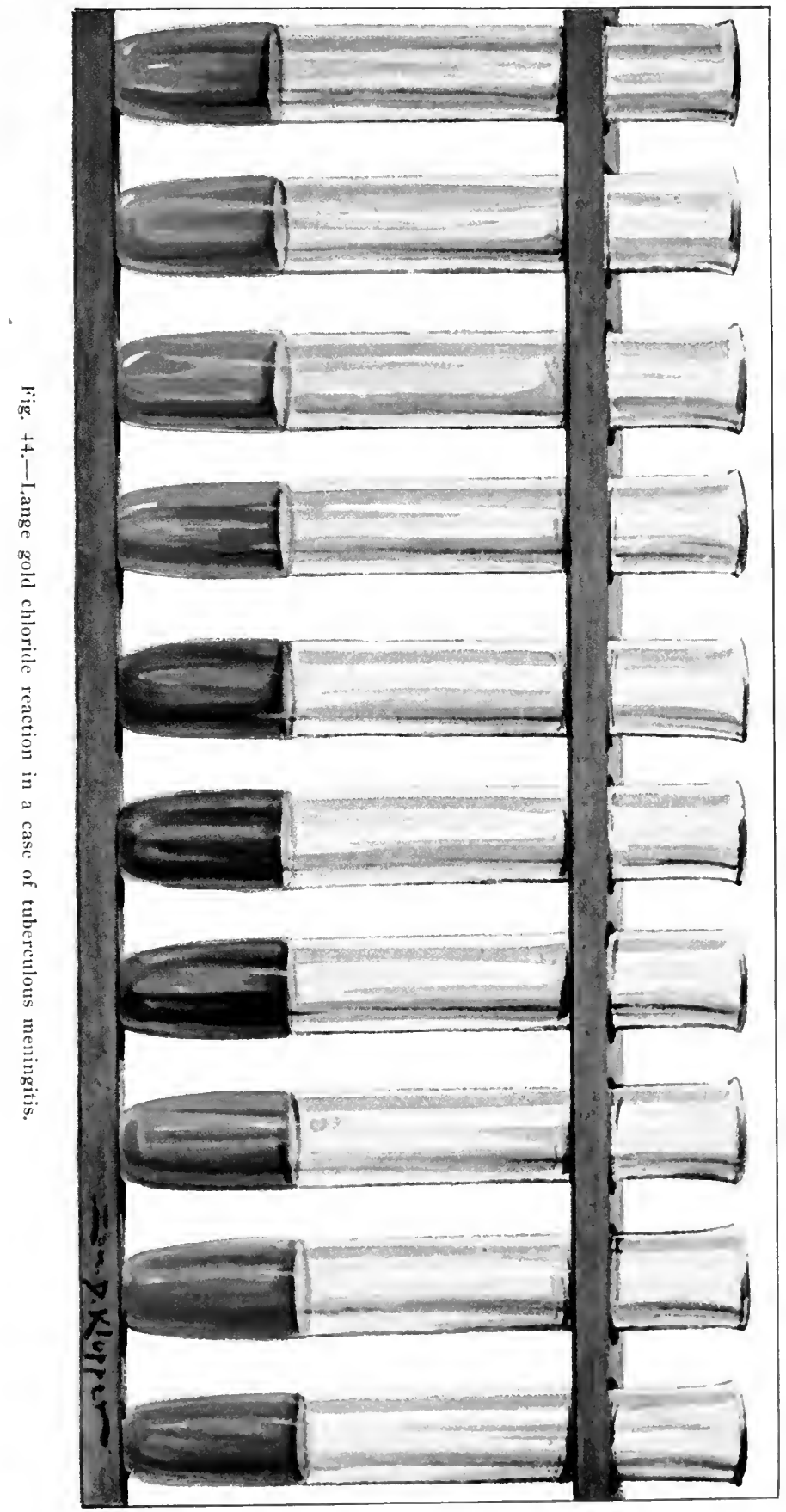



The cataphoresis shows most of the protein moving toward the anode. Upon evaporation long crystals form in the fluid. The sulphosalicylic mercuric chloride ratio is marked, the precipitate with mercuric chloride being three times as great as that of the sulphosalicylic on standing.

Tubercle bacilli are found in the centrifuged fluid only after a careful search. They are often found more easily in the pellicle. Inoculation of the cerebrospinal fluid of tubereulons meningitis in guinea pigs produces a miliary tuberculosis in the animal in course of one to six weeks.

From a diagnostic standpoint the following are the most important changes in the cerebrospinal fluid of tuberculous meningitis: Increase in amount and pressure, increase in the number of cells with a relative lymphocytosis, positive Noguchi, Ross-Jones, and Nonne tests, sulphosalicylic mercuric chloride ratio, high permanganate index, low chlorides, Lange curve, and above all the presence of tubercle bacilli in the fluid, and the development of tubereles in guinea pigs after inoculation.

The following case will illustrate the cerebrospinal fluid findings in a case of tuberculous meningitis:

D. H., eleven and one-half years of age, entered the hospital eomplain. ing of headache, vomiting, extreme constipation, anorexia, and weakness. The onset was slow with vomiting and headache, the vomiting being projectile in type. The patient beeame listless and sleepy. Examination showed marked symptoms of meningeal irritation. A spinal puneture was performed. The fluid obtained was clear and under marked pressure. The cell count showed 320 cells per eubie millimeter, 98 per eent of which were lymphocytes and 2 per cent polymorphonuclear leucocytes. The Noguehi and Ross-Jones globulin tests were strongly positive. The permanganate index was 3.0. The mereuric ehloride sediment was four times the size of the sulphosalicylie sediment. The direet smear showed no organisms. The blood showed 80 per cent hemoglobin, 5400 lencocytes per eubie millineter, of wilich, 5 s pereent were nentrophiles; 20 per cent small mononuclear and 12 per cent large mononuclear. The Widal reaction was negative, so were the blood cultures.

The ehild beeame progressively worse and another spinal puneture was done the next day with practically the sane findings as the first specimen with the additional finding of a pellicle when the flnid was allowed to stand. $A$ third puncture showed all globulin tests to be positive, the gold 
ehloride reaction was also characteristic of tubereulous meningitis. The patient died after staying twelve days in the hospital. The postmortem showed a grayish white, purulent exudate at the base of the brain, measuring $0.5 \mathrm{~cm}$. in thickness, the exudate covering the region of the hypophysis and the right optic nerve. A part of it also extended to the right of the longitudinal fissure in the region of the parietal lobe. The exudate showed the presence of tubercle bacilli. Caseated glands were found. in the hilus of the lung.

\section{Meningococcus Meningitis}

In meningococcus meningitis, the amount of the cerebrospinal fluid is increased, and as a rule, 20 to 40 c.c. can easily be removed by one lumbar puncture. This increase in the amount of the fluid is a constant feature of meningococcus meningitis throughout the disease. Only very seldom does it happen that the amount of the fluid is not increased. Cases of this kind usually have an occlusion of the subarachnoid space somewhere along the tract of the cerebrospinal stem.

The pressure of the fluid in meningococcus meningitis is also increased ranging between 300 to $700 \mathrm{~mm}$. water high. In two of my cases the pressure was as high as $800 \mathrm{~mm}$. of water.

The color of the fluid of meningococcus meningitis varies from a slight opalescence at the onset of the disease to a yellowish green later in its course. The yellowish green color is the product of the meningococcus. On standing it sometimes becomes a pronounced green. The fluid continnes turbid throughont the course of the disease. It rarely happens that the fluid in the early stages of epidemic meningitis is clear and colorless. On standing one-half hour or longer the fluid forms a sediment that changes in character with the development of the disease.

(a) In the early stages of the disease, the pellicle is made up of a yellowish-white network, the reticuli being close together and forming an opaque layer. The upper portion of the network is balloon- or dome-shaped and the base or lower portion is flattened in appearance. The whole net- 


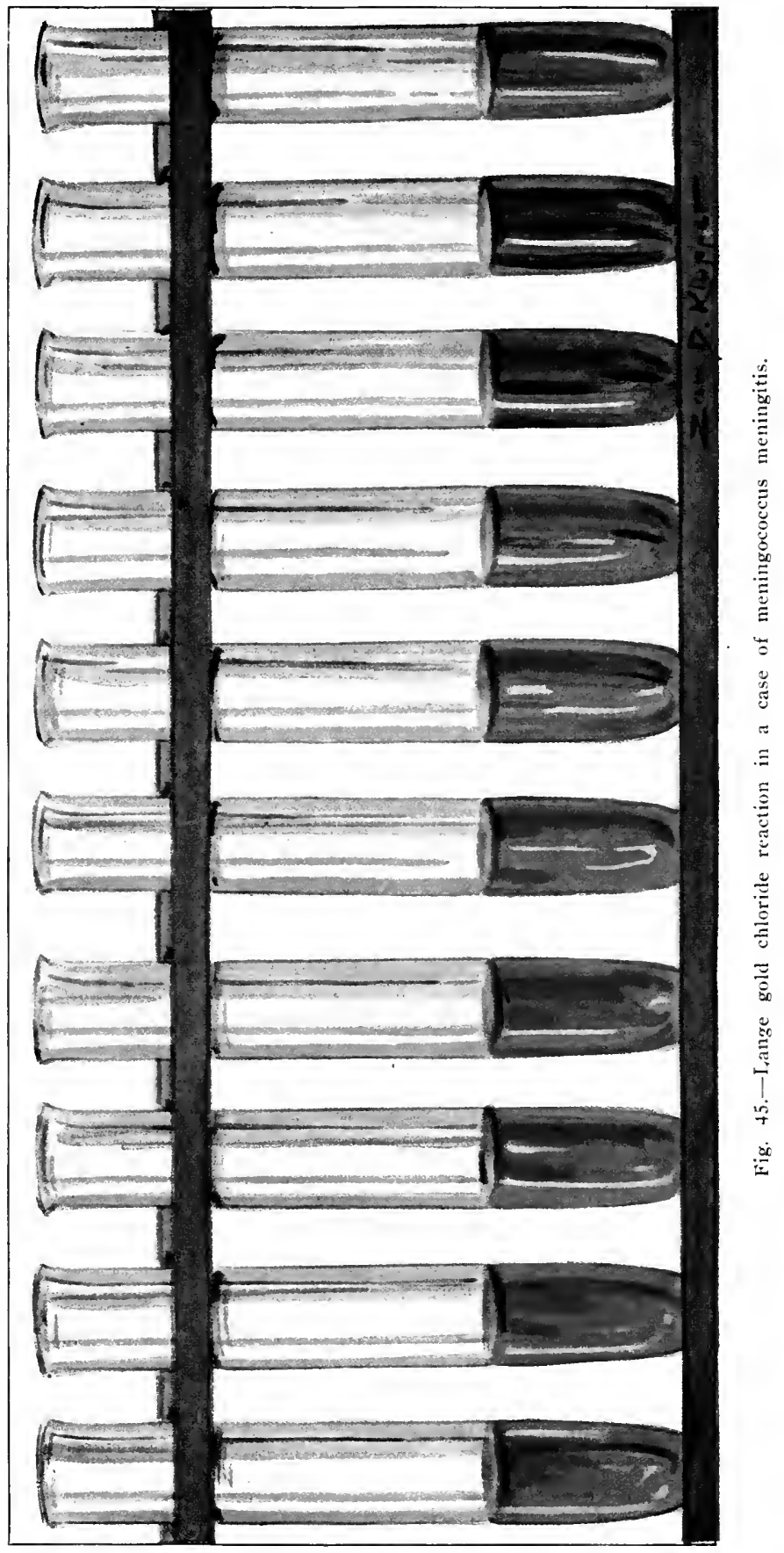


work resembles a small bursa. It usually does not reach the upper level of the fluid and generally it is seen inclining toward one side of the tube.

(b) In the more advanced stages of meningitis, the sediment formation is firmer. It generally spreads out along one side of the tube in the form of a heavy film.

(c) In still more advanced cases, a sediment of yellow gramules may be seen attached to one side of the tube. These granules are an indication that the disease has progressed to an advanced stage.

(d) In the very grave cases the sediment is thick and falls by gravity to the bottom.

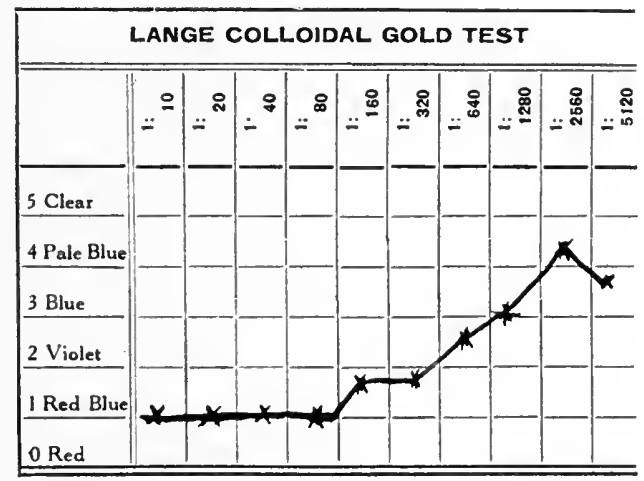

Fig. 46.-Case of meningococcus meningitis.

When the meningitic process recedes, the pellicle or sediment takes on a character the reverse of the one that appeared at its formation. The chemical changes are marked. The organic index determined by the permanganate is high, ranging between 5 and 7 . The protein content is greatly increased ranging between 1 and 7 per cent. The Noguchi, Ross-Jones, Nonne and Pandy globulin tests are strongly positive. A 3 per cent sulphosalicylic acid solution gives a heavy sediment on standing, measuring from 10 to $20 \mathrm{~mm}$. in height, while a 1 per cent mercuric chloride solution gives a sediment much lower than the sulpho- 
salicylic acid. The sugar is usually absent or greatly diminished during the active stage of the disease. Lactic acid is present in the fluid in large quantities. The chlorides are usually the same as normal, although they may be present in quantities less than normal.

Among the physicochemical changes that take place in meningococcic meningitis the following are important: Cataphoresis shows that the protein migrates to the cathode pole. The H-ion concentration is increased and it continues high for a long time after the removal of the fluid

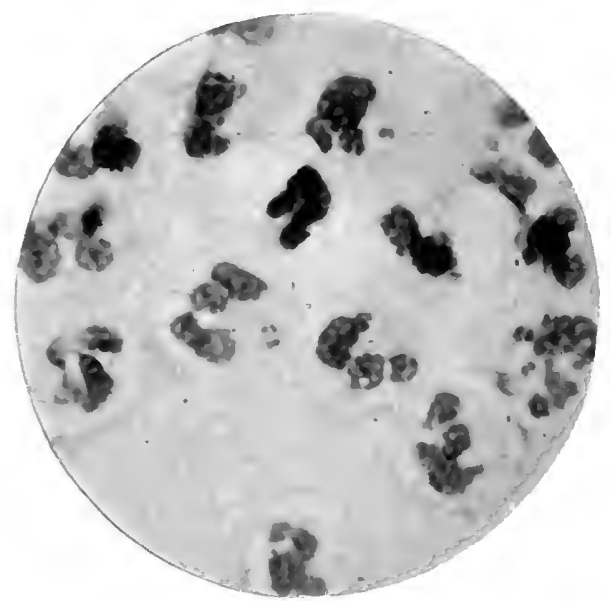

Fig. 47.-Photomicrograph showing direct smear from cerebrospinal fluid of case of meningococcus meningitis.

from the body. The alkali reserve does not run parallel with the H-ion concentration. The riscosity is 1.0434 to 1.0735. The gold chloride test shows the greatest discoloration in Tubes 7,8 , and 9 (Figs. 45 and 46).

The cytologic changes are distinct. The leucocytes are increased in number, varying from 50 to several thousands per cubic millimeter. The greatest percentage of the cells (90 to 98 per cent) is made up of polymorphonuclear leucocytes, although the lymphocytes are also present in greater number than in normal fluid.

The bacteriologic findings are fairly constant. A gram- 
negative biscuit-shaped organism is usually foumd in the direct smear within the lencocytes, some being found also outside of the leucocytes (Fig 47). The number of organisms found in the smear of epidemic meningitis is not nearly so great as that found in the smears from pneumo-

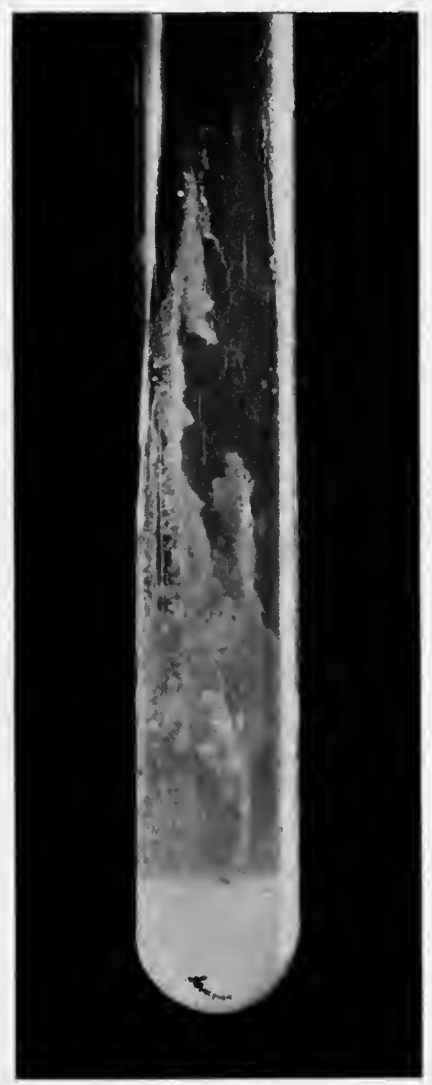

Fig. 48.-Twenty-four-hour culture of meningococci grown on ascitic dextrose agar. The culture which has been originally obtained from a case of meningococcus ineningitis has been transplanted several times on artificial media, hence the heavy growth in twenty-four hours.

coceus fluid. It sometimes happens that early in the disease the organisms in the direct smear are very scanty in number, but after the first or second dose of antimeningococeic serum, there is a shower of organisms in the fluid. 
On ascitic dextrose agar, the meningococci usually grow in pure culture (Figs. 48 and 49) although it is not always easy to grow them. The meningococci can be differentiated from the pneumococci by the gram stain, the meningococci being gram-negative and the pneumococci grampositive. It is also possible to differentiate the two by the agghtination test. On the other hand, it is very difficult to differentiate the meningococci from other gram-negative cocci such as gonococcus, micrococcus catarrhalis, and diplococcus mucosus. However, since these organisms rarely

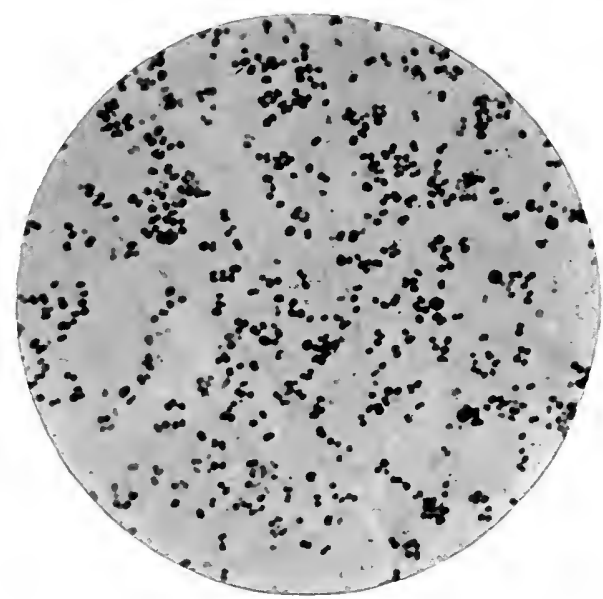

Fig. 49.-Photomicrograph of pure meningococcus culture. Twenty-four-hour growth.

ever produce meningitis it is seldom necessary to take them into consideration.

Occasionally it happens that a case of meningitis shows meningococci in the cerebrospinal fluid both in the direct smear and in the culture, but several days later examination of the fluid shows both meningococci and pneumococci or pneumococci alone. Such cases have been reported by Netter and Salonier, by Mathers and by Fitzgerald. Two such cases of mixed infection also came under my observation. 
One must, however, be careful in lis staining technic to avoid reaching erroneous conclusions. Above all, even when the existence of a mixed infection of meningococeus and pneumococcus has been established one must not neglect giving the patient antimeningococeus serum, as this is the only hope left for him.

After several doses of antimeningococcus serum have been administered to the patient and the case shows improvement, the cerebrospinal fluid gradually changes in all respects. The fluid becomes less and less turbid by degrees, the color remains yellow because of the color of the serum, but it loses its greenish tint. The amount withdrawn at each sitting is smaller than at the height of the disease; the pressure becomes lower, the protein content becomes less, and the pliysicochemical changes grow less and less distinct. The cells decrease in number and the type of cell changes from polymorphonuclear to lymphocyte. The bacteria also gradually disappear after several doses of serum.

The following reports give the average findings in the cerebrospinal fluid of meningococcus meningitis:

I. M. G., Flnid eloudy, cell count 51, differential count 90 per cent polymorphonuelear leueocytes. Noguchi, Ross-Jones, and Nonne, positive. Sulphosalicylic gives heavy precipitate, mereuric chloride produces only turbidity. Sugar 0.01 per cent. No baeteria found in direct smear.

Twenty-four hours later: Gram-negative organism on ascitic dextrose agar agglutinating in 1:200 dilution. Sulphosalieylic sediment measures 20 mm., mereuric chloride $5 \mathrm{~mm}$., albumin by modified Esbach 0.1 per cent.

Fluid examined after administration of 30 c.e. of antimeningoeoceus serm, - very cloudy. Cell count 218; Noguchi, Ross-Jones, and Nonne positive. Sulphosalicylic gives heavy precipitate, mereuric ehloride only turbidity. Sugar absent. Gram-negative eocei in smear.

Twenty-four hours later: Gram-negative organisms in culture, agglutinating in 1:200 dilution, sulphosalicylie sediment $24 \mathrm{~mm}$, meremic ehloride 6 mm., albumin 0.15 per eent.

Flnid withdrawn after administration of 120 e.e. of antimeningococeus serum. Appearance yellow. Cell count 14. Differential count 50 per eent polymorphomelears. Globulin tests slightly positive. Sugar 0.07 per cent. No organisms in direct smear or in enlture. 
II. E. C. Fluid turbid. Cell count 14,000; differential count 95 per cent polymorphonuclear; occasional endotlielial cell. Noguchi, Ross-Jones, and Nonne positive. Sulplosalicylic very heavy precipitate; mercuric chloride turbid. Sugar absent. Chlorides 0.6 per cent. Permanganate index 4.0. Gram-negative intracellular diplococci.

Twenty-four hours later: No growth on aseitic dextrose agar. Albumin 0.15 per cent. Sulphosalicylic sediment $18 \mathrm{~mm}$; mercuric chloride $6 \mathrm{~mm}$.

Forty-eight-hour report: Gram-negative diplococei agglutinating antimeningitic serum in $1: 250$ dilution.

\section{Pneumococcus Meningitis}

In pneumococcus meningitis the cerebrospinal fluid is greatly increased in amount, ranging between 20 and 50 c.c. of fluid in one puncture. The color of the fluid varies according to the stage of the disease, but as a rule, it is pearly gray, in contrast to the greenish yellow of the fluid of meningococcus meningitis. On standing, a heavy sediment forms which is usually fibrinous in character, the amount of fibrin being greater in the pneumococcic than in the meningococcic form.

In pneumococcus meningitis, the amount of protein is greatly increased ranging between 0.1 and 0.7 per cent. Thus all globulin tests are strongly positive. The amount of sugar is less than normal and very often is absent altogether. Chlorides are generally present in the same amount as in normal fluid, ranging between 0.6 and 0.74 grams per 100 c.c. of cerebrospinal fluid.

The physicochemical changes are usually the same as in the meningococcus type. The cells in the fluid are numerous, numbering as high as 1000 or more per c.mm. The greatest percentage of the cells are polymorphonuclear lencocytes. The pnemmococci which are usually found with ease in the direct smear are present in great numbers. At times there are many gram-positive bacteria in the smear and very few cells. (Fig. 50.)

The bacteria often are arranged in chains of four or six, thus making it difficult to differentiate pneumococeus from 


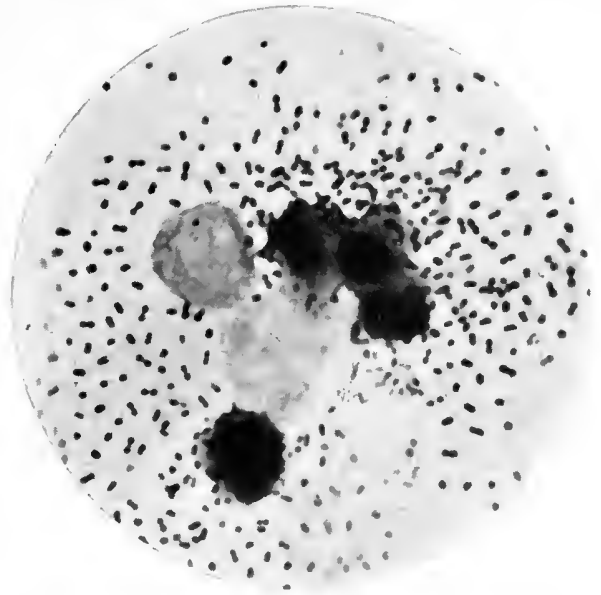

Fig. 50.-Photomicrograph of smear from cerebrospinal fluid of pneumococcus meningitis.

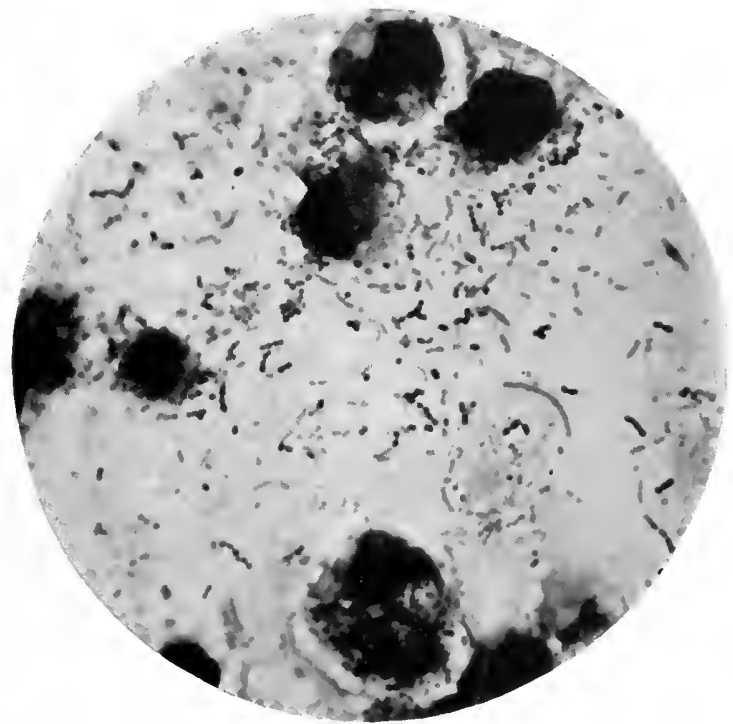

Fig. 51.-Photomicrograph showing direct sncar from cerebrospinal fluid of case of mixed streptococcus and pneumococcus meningitis.

streptococcus. Howerer, the fluid of pnemmococeus meningitis contains a more fibrinous pellicle than does that of streptococcus. The capsule stain is also of assistance in differentiating between the two bacteria. The final diag- 
nosis, however, must rest on the character of the culture and on the agghtinative properties of the organism. At times, however, there is a mixed pnemmococens and streptococcus infection of the meninges (Fig. 51).

E. B., three and one-half months old, brought to hospital with a history of fever and rigidity of neck of one reek's duration. Physical examination showed, in addition to rigidity of neek, a positive Kernig sign, positive Brudzinsky and twitchings of the right side of the body. The cerebrospinal fluid removed by humbar puncture, was increased in pressure and very turbid. The cells numbered 1400 per eubie millimeter, of which 52 per cent were polymorphonuclear leucoeytes, and 48 per cent were lymphocytes. Noguchi, Ross-Jones, and Nonne globulin tests were positive. Sulphosalieglie gave a heavy turbidity and mereurie chloride only a very slight turbidity. The chlorides were $0.66 \mathrm{per}$ cent. Quantitative protein ly modified Esbach 0.1 per cent. The gold chloride test gave a discoloration in the seventh, eightl, and ninth tubes. The direct smear showed gram-positive, lanecolated organisms, arranged in pairs, which, however, did not agglutinate with eitler Type I, Trpe II, or Type II antipneumococeus serum.

The patient became progressively worse. Another lumbar puncture was made twelve hours later, but only 2 c.e. of rery thick cerebrospinal fluid was oltained. A rentricular punctuie was thereupon made and 25 e.e. of eerehrospinal fluid was obtained. The fluid was turbid but not as turbid as that olstained by lumbar puncture. The eells numbered 150 per eubie millimeter, the globulin tests were all positive, the ehlorides read 0.74 per cent and the direct smear showed the same organism as in the first fluid.

Twenty e.e. of polyvalent antipneumoeoecus serum was injected into the ventricle by gravity method. The patient, lowever, grew coustantly worse and died eighteen hours after the injeetion of the serum.

\section{Streptococcus Meningitis}

In my experience, hemolytic streptococei were found to be the most frequent type of streptococcus producing. meningitis, although many cases of nonhemolytic streptococeus meningitis also came to my attention.

The cerebrospinal fluid of all forms of streptococcus meningitis is very turbid. It is increased in amount and in pressure. The protein content is also increased and all globulin tests are positive. The cells are also increased and 90 to 95 per cent of them are polymorphonuclear lencoeytes. The streptococei are found in the direct smear (Fig. $51)$ and in culture. To differentiate between the types of 
streptococcus, the fluid should be put on blood agar. The hemolytic streptococei will produce hemolysis.

\section{Influenza Meningitis}

This not infrequent form of meningitis gives an increased amount of fluid which varies in color from a slight opalescence to a distinct yellow. The cells in this condition are increased in number and range from 100 to 400 per c.mm. As a general rule, the cells are almost entirely polymorphonuclears, although occasionally one may find as high as 40 to 50 per cent of the cells to be lymphocytes. Gram-negative bacilli are found extracellularly in the direet smear in large numbers. (Figs. 52 and 53.) However, a special medium containing hemoglobin is required to grow the influenza bacilli.

\section{Colon Meningitis}

Colon meningitis, typhoid meningitis and gonococeus meningitis have been reported in the literature. These conditions are very rare, however. Their findings are the same as those manifested in other forms of suppurative meningitis. The diagnosis in these conditions can be made upon recovering the bacteria from the cerebrospinal fluid and enlture. It can also be made on the characteristic agghutination tests.

\section{Syphilitic Meningitis}

Chronic syphilitic involvement of the meninges is rather frequent, but as a rule remains unrecognized, giving few symptoms or signs. Acute syphilitic meningitis is less frequent, but it does occur occasionally and one must always keep it in mind in eases where a meningitis exists and where the exciting organisms can not be recovered from the cerebrospinal fluid culture and where the clinical symptoms do not justify a diagnosis of either tuberculous meningitis or polionyelitis.

The cerebrospinal flnid in acute syphilitic meningitis is 
clear or slightly opalescent. It is moderately increased in anount, gemerally from 15 to 25 c.c. of cerelnospinal fluid at

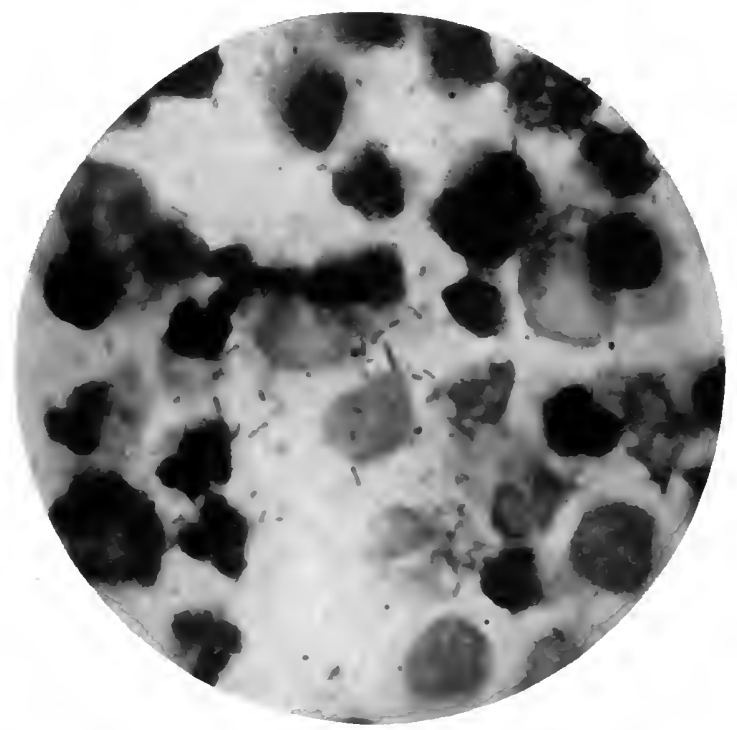

Fig. 52.-Photomicrograph showing direct smear from cerebrospinal fluid of case of influenza meningitis.

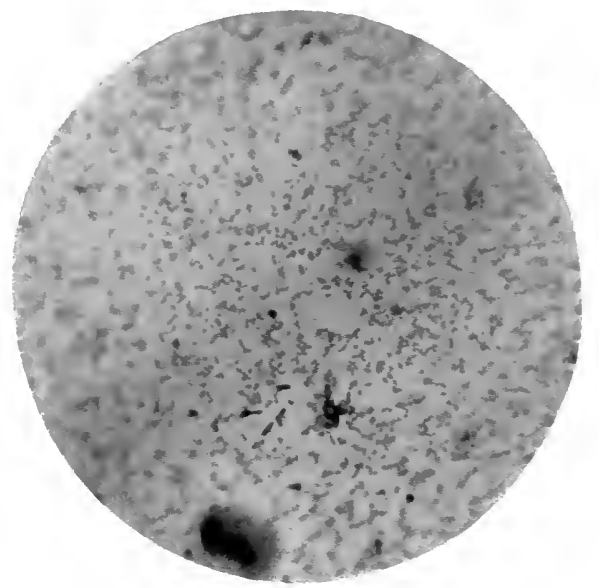

Fig. 53.- I'hotomicrograph of pure culture of influenza bacilli.

one sitting. The fluid is moderately increased in pressure. The globulin tests are positive. The cells are greatly in- 
creased in number, rumning between 100 to 600 cells per cubic millimeter, 60 to 80 per cent of the cells are lymphocytes. The smear's and cultures are negative to bacteria, but on careful search with the India-ink method one may find the presence of Spirochete pallida. The Wassermann is positive. The Lange gives a reaction in the syphilitic zone.

\section{Cerebrospinal Fluid in Poliomyelitis}

The fluid is increased in amount ranging between 20 to 50 c.c. at one sitting.

The pressure is increased, ranging between 300 to 700 mm. of water in height.

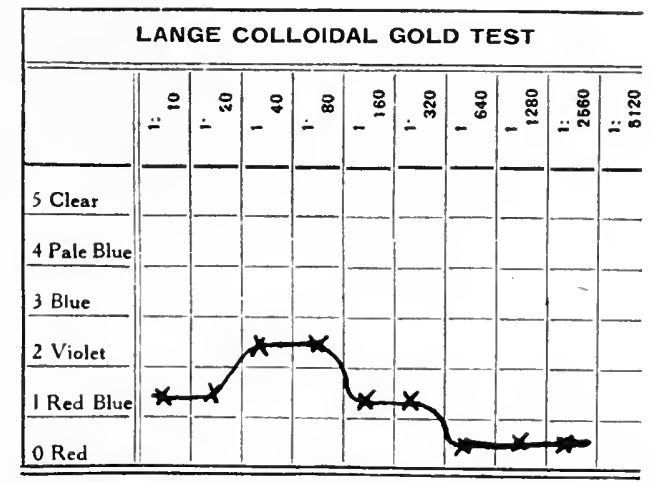

Fig. 54.-Case of epidemic poliomyelitis. First week of disease.

It is usually colorless, only oceasionally being opalescent. On shaking the fluid, a thick foam is produced which does not disappear for some time.

The permanganate index is slightly above the normal averaging 1.5 to 2.5 . The protein is usually increased in amount, generally giving positive globulin tests, although once in a while the globulin tests are negative.

The gold chloride test in the preparalytic stage, shows either no change at all, or a change in the luetic zone only. (Fig. 54.) After the subsidence of the acute symptoms, from the second to the twelfth day, the reaction may be most prominent in the meningitie zone. The cells in this condi- 


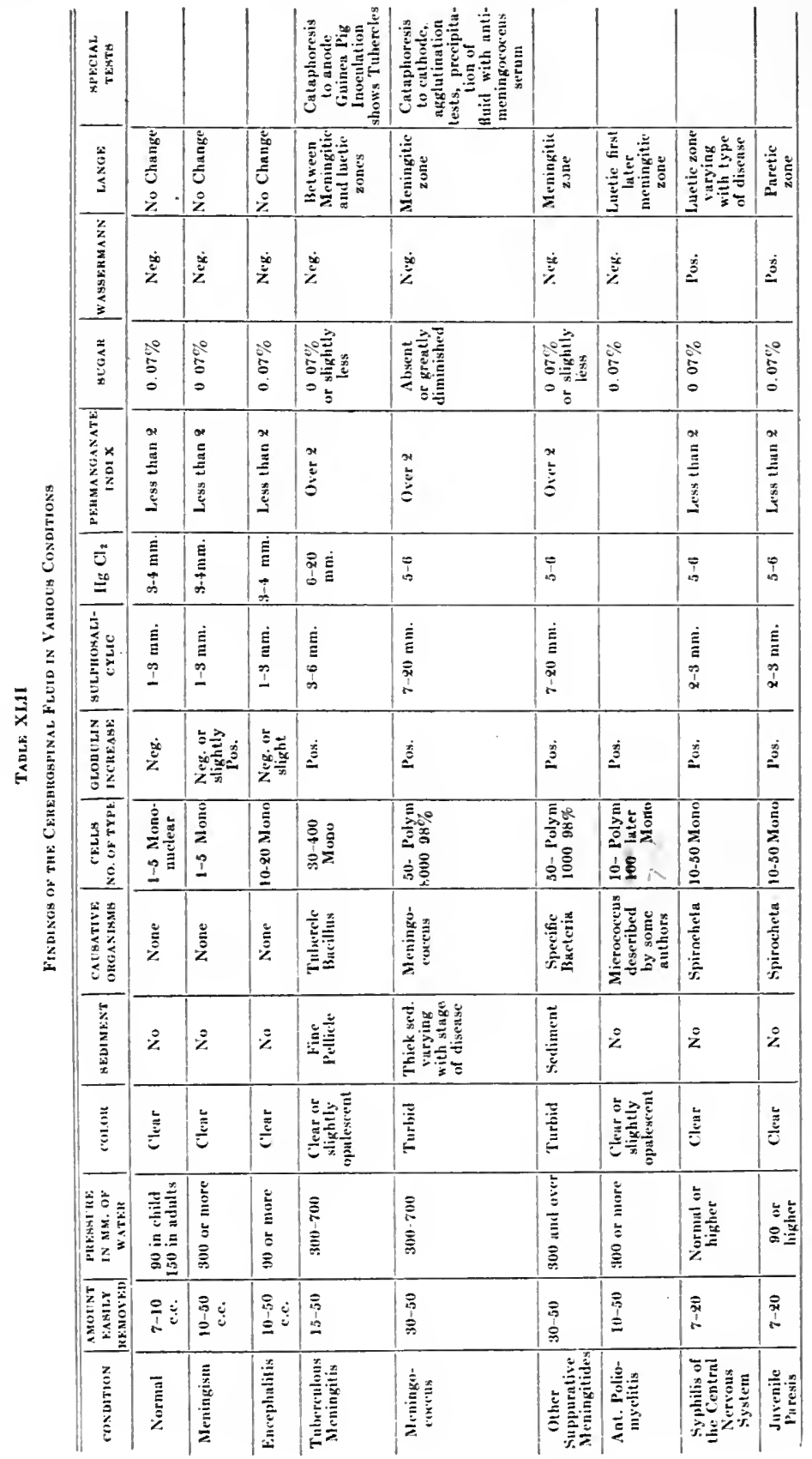


tion are increased in number, 90 per eent of them being of the small, mononuclear type. The increase manifests itself in the preparalytic stage and lasts fourteen to sixteen days after the onset of paralysis. The cells are greatest in number during the first week after the onset of paralysis. The largest percentage of cells (60 to 90 per cent) is of the small lymphocyte type, except in the very early stage of the disease when the predominating cell may be the polymorphonuclear.

The bacteriology of poliomyelitis is still an open question. Flexner and Lewis found a filtrable virus. Mathers, Nuzum and Rosenow report the finding of a micrococeus in the brain and cord. Nuzum reports the presence of the coccus in the cerebrospinal fluid. The organism, according to these authors, is grown best on a 1 per cent glucose broth medium, incubated under aerobic conditions. Other workers dispute the specificity of this microorganism in poliomyelitis. At the present state of our knowledge no positive diagnosis can be made of poliomyelitis by the fluid findings alone. The history of the case and its progress must always be taken into consideration as well.

\section{Bibliography}

Acehiote: Poliomyelite anterieure aigue et lymplocytose, Rev. newrol., 1911, xix, 711 .

Apelt and Sehumm: Untersuehungen über Phosphorsauregehalt der Spinalflüssigkeit, Arch. f. Psyehiat., 1908, xliv, 2.

Arzt and Boese: Über Paratyphusmeningitis im Säuglingsalter, Wien. klin. Wehnsehr., 1908, xxi, 217.

Ayer and Viets: Spinal Fluid Findings Characteristic of Cord Compression, Jour. Am. Med. Assn., 1916, lxvii, 1707.

Bailey: Cryoseopy of Cerebrospinal Fluid in Epidemie Cerebrospinal Meningitis, Med. Ree., 1905, lxvii, 215.

DuBois and Neal: Streptococeus Meniugitis With Report of a Cured Case, Areh. Pediat., 1915, xxxii, 2S.

Dupré: Le Meningisme, Congres francais de Medecine, 1894, Paris, 1895, i, 411.

Eisberg and Rochfort: Xanthochromia and Other Changes in the Cerebrospinal Fluid, Jour. Am. Med. Assn., 1917, lxviii, 1802.

Ferrier: Cytologie du Liquide Cephalo-Rachidien dans la Lencennie, Compt. rend. Soc. de biol., 1908, 803 .

Flexner and Lewis: The Nature of the Virus of Fpidemie Polionyelitis, Joul. Am. Merl. Ass11., 1909, liii, 2095.

Flexner and Noguchi: Experiments on the Cultivation of the Microorganism Cansing Epidenie Polionyelitis, Jonr. Exper. Med., 1913, xviii, +61, 
Fraenkel, E.: Über das Verhalten des Gehirus bei akuten Infektionskrankleiten, Virchows Arch. Beiheft 1908, p. 194.

Froin: Le liquid eephalo-rachirlien dans l'hemorragie cerebromeningee, Gaz. d. lôp., 1913, lxxvi, $100 \overline{\text { s. }}$

Futh and Lockemann: ¿̈ber den Nachweis von Fleisshmilchsaure in der Cerebrospinalflüssigkeit kklamptischer, Areh. f. Gronecol., 1905, lxxvi.

Ghon, Mueha and Muller: Zur der akuten Meningitis, Centralbl. $f$. Bakt. 11. Parasitenk, xli, 1.

Hartwieh: Bacterium coli im Liquor Cerehrospinalis, Berl. klin. Wchnsehr., 1911, xli, 18, 795.

Jacoh, P.: Echinocoecus und Zerebrospinalflüssigkeit, Fortselnr. d. Med., 1903.

Jochmann, G.: Meningitis cerebrospinalis Epidemica, Mohr Staehelin Handbuch d. inn. Medizin.

Lesser: Tahes und Paralyse im Lichte der neuren Syphiliserforselung, Berl. klin. Welunschr., 1908, 1762-1764.

Mathers: The Etiology of teute Epidemie Poliomyelitis, Jour. Infect. Dis., $1917, \mathrm{xx}, 113$.

Mathers: Some Bacteriologic: Olsservations on Epilemic Poliomyelitis, Jour. Am. Med. Assn., 1916, lxvii, 1019.

Mohr, R.: Zur Pathologie des Liquor Cerebrospinalis, Deutsch. Ztschr. f. Nervenh., xliv, 417.

Nome and Apelt: Z̈ber fraktionierte Eiweissausfällung, ete., Arcl. f. Psyehiat., 1907, xliii, 2.

Nonne: Syphiiis md Nervensystem, ed. 2, Berlin, 1909, 631-634.

Nonne and Holtzmann: Teber. Wassermann-Reaktion im liquor spinalis bei Tahes dorsalis, sowie über quantitative Auswertung ron Starkegraden der Wassermannschen Reaktion bei syphilidogenen Krankheiten des Zentralnervensystems, Monatschn f. Psychiat. u. Neurol., 1910, xxrii, 128.

Ninum and Herzog: Experimental Studies in the Etiology of Acute Epidemic Poliomyelitis, Jour. Am. Med. Assn., 1916, lxvii, 1205.

Oscki: Makroskop. latente Meningitis u. Encephalitis bei akuten Infektionskrankheiten, Beiträge zur pathologisehen Anatomie u. z. allg. Path., 1912, lii, 540 .

Pappenhein: Leber die Polyuukleose im Liquor eerebrospinalis, bei der progressiven Paralyse. Ztschr. f. N. Heilk., 1907, xxriii, 10, 315.

Quineke: Über Meningitis serosa, Samml. klin. Vortr. r.Volkmann, 1893, p. 65.5 .

Redlich, Potzl, and Hess: C'ntersurhnngen über das Verhalten des Liquor cerebrospinalis hei der Epilepsie, Ztsclir. f. d. ges. Neurol. u. Psychiat., 1910, ii, 715 ; ibid., 1910, iii, 492 .

Rist, F.: Teue Methoden, ete., Centrall,l. f. Bakteriol. u. Paras., 1901, xxx.

Romheld: Zur Klinik postdiptherischer Lalımungen; Liquorbefund bei postdiptheriseher Psendotabes, Vortrag. Ref., Nenrol. Centralbl.. 1908, 1007.

Rosenow, Towne and Wheeler: Etiology of Fidemic Poliomyelitis, Jour. Am. Med. Assn., 1917, lxvii, 1202.

Schottmüler: Meningitis Cerebrospinalis Epirlemica (Weichselbaum), München med. Wehnsehr., 1905, lii, 617, 1683, 1729.

Schottmüller: Zur Bedeutung einiger Anaerobier in der Pathologie, Mitteilungen aus d. Grezgebeiten d. Med. u. Chir., xxx.

Sehottmüller and Schumm: Nachweis rn Alkohol in der Spinalflüssigkeit ron Sanfern, Teurol. Centrall,., 1912, xxxi, 1020, Münehen Med. W'chnschr., 1910.

Sehultze: Zur Diagnostik der akuten Meningitis, Verhandl. d. Cong. f. inn. Med., 1867, p. 393 .

Staubli: Meningrismms typhosus u. Meningotyphus, Deutsch. Areh. f. klin. Med., 1904-1905, Ixxxii, 90.

Wollstein: Influenza Meningitis and its Experimental Production, Am. Jour. Dis. Chilıl., 1911, i, 42. 


\section{CHAPTER VIII}

\section{INTRASPINAL TREATMENT}

Whenever there is a specific remedy for a disease of the central nervous system, it is of the utmost importance that the remedy be brought into direct contact with the central nervous system as early as possible. Even when no specific exists, it may be advisable to introduce some form of medication into the cerebrospinal fluid. The injection is made either intraspinally, or intraventricularly.

\section{Intraspinal Treatment of Meningococcus Meningitis}

The reports of Flexner and his associates, and the experience of most physicians, have established the fact that the best and most successful way of treating meningococeus meningitis is by means of antimeningococens serum. The mortality of cases of meningitis that received serum has been reduced to one-half, in some epidemies to one-third of the mortality of cases that received no serum, as is shown by Table XLIV from Sophiam.

TABLE XLIV

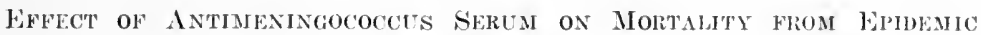

Meningitis

\begin{tabular}{lccc}
\hline \hline AUtion & CASES TREATED & $\begin{array}{c}\text { WITH SERUM } \\
\text { Percentage } \\
\text { Nortality }\end{array}$ & $\begin{array}{c}\text { CASES TREATED } \\
\text { WiTHOUT SERUM } \\
\text { Percentage } \\
\text { Nortality }\end{array}$ \\
\hline Flexner & 1,400 & 31.4 & $70-80$ \\
Steiner & 2,280 & 37.0 & 77 \\
Netter & 100 & 28.0 & 49 \\
Topter & 402 & 16.44 & 52.14 \\
Levy & 165 & 18.18 & 65 \\
Sophian & 161 & 15.5 & \\
\hline
\end{tabular}


The antimeningococcus serum now in use is prepared by repeated injections of dissolved meningococci (culture autolysate meningococci extract) into a horse followed by injections of live meningococcus cultures. The cultures used are of various strains of meningococci, so that the serum is polyvalent.

The serum is tested before it is put up in packages, by one of several methods: the complement-fixation method, the agglutination test, the opsonin content and the animal protection test. In England the aggrutination test is used very extensively. In France the complement-fixation method is the one most generally employed. In America all four methods are used by various manufacturers. McCoy, Wayson and Corbitt of the United States Public Health Service, aceept any serum which passes satisfactorily, either by an agglutination or complement-fixation test as a suitable serum for therapentic purposes.

The antimeningococeus serum is usually preserved with 0.2 per cent to 0.3 per cent of tricresol. The use of this preservative has given rise to a number of objections. Kramer ascribes some of the deaths that had occurred after the injection of antimeningococeus serum to the use of tricresol which he claims has a very depressing effect on the medullary center. It has been found, however, that of the different preservatives nsed, tricresol exerts the most marked bactericidal effect on the hacteria, and is a much less irritating preservative than chloroform. It is therefore used exclusively in this country as a preservative of antimeningococcus serum.

Whenever a case presents itself that shows signs and symptoms of meningitis, and gram-negative cocei in the smear, no time should be lost in injecting the patient with antimeningococcus serum. Te may even go a step further and say that whenever a tmbid cerebrospinal fluid is obtained antimeningocoecus serum should be injected immediately on the probability that the case is one of epi- 
demic meningitis. Of late the intravenous injection has been advocated, but even when intravenons injection of serum is employed the serum should be injected into the cerebrospinal canal also if there are indications of the presence of meningitis.

The following is the technic of intraspinal injection of serum :

A lumbar puncture is done with the patient lying on his side. (The entire procedure is described in detail in Chapter III.) If the fluid removed is turbid, 15 to 30 c.c. of cerebrospinal fluid is withdrawn, the amount depending upon the pressure of the cerebrospinal fluid and the quantity of serum to be administered. One or two vials of antimeningococeus serum which have been kept in the refrigerator are warmed in warm water to 98 or $99^{\circ} \mathrm{F}$. The vial containing the serum is attached to a gravity tube made of rubber with small stylet to fit the lumbar puncture needle (Fig. 55). The stylet of the gravity tube is now introduced into the lumbar puncture needle and the vial is lowered slightly to allow the air bubbles that may be present in the gravity tube to escape. The process of emptying the vial should take from 10 to 15 minutes. If more than 15 c.c. of serum is to be administered, the second vial is attached to the gravity tube after the first vial has been emptied, and the fluid allowed to run in, eare now being taken that no air bubbles are allowed to enter the gravity tube during the removal of the vial.

If the serum does not flow readily into the spinal canal the vial containing the serum should be lowered to allow the air bubbles to rise to the surface. If this does not bring the bubbles to the surface, squeezing the gravity tube may do it. This should be done very cautiously, however, to prevent the pushing of air bubbles into the spinal canal. If the serum still does not flow into the canal, it is advisable to use a small sterile bulb on the vial to press in the fluid, This procedure has often given me good results. 
Some authors advise the washing of the spinal canal with sterile salt solution before the injection of the serum. In my opinion this procedure is neither necessary nor advisable.

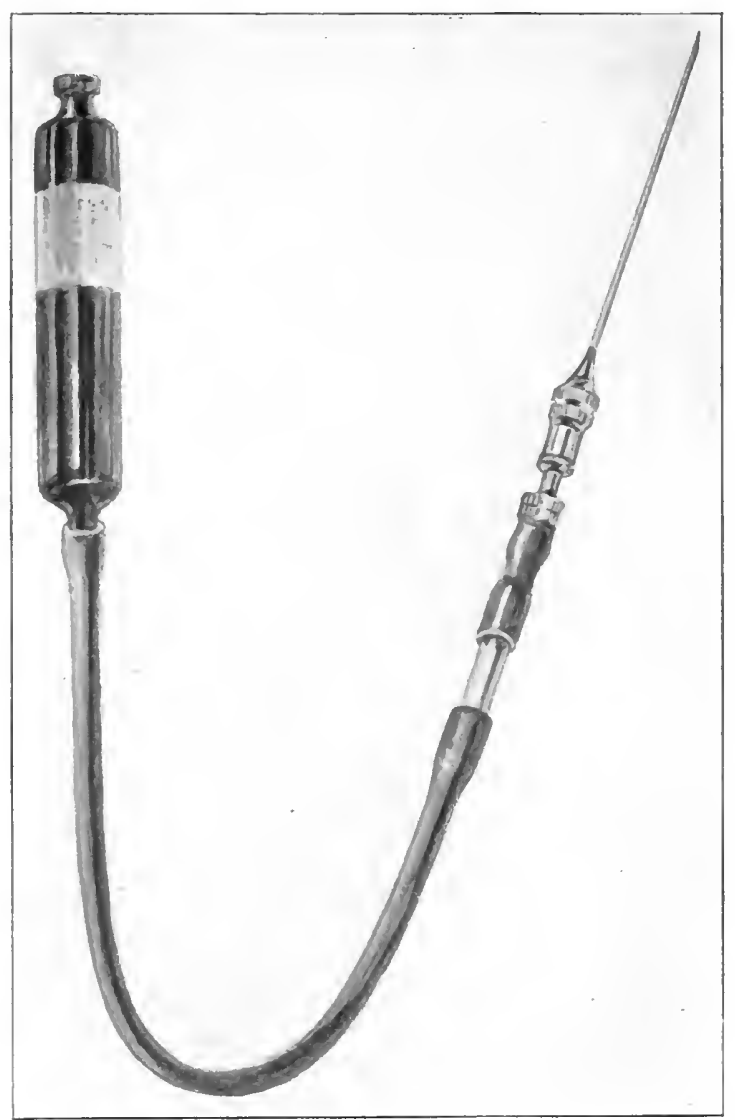

I.ig. 53.-Instrument for the introduction of antimeningococcus serum by the gravity method.

As for the dose of serum to be administered at one time, no absolute rule can be given. Sophian advises the use of blood pressure as an index, a marked fall in blood pressure being an indication to stop the injection of sermm. One may always guide oneself by the amount of fluid removed 
inclining toward the larger rather than the smaller dose. For example, it is best to administer 30 c.e. of serum the first time if it is possible to remove 30 c.e. or more of cerebrospinal fluid. If not more than 15 or 20 c.c. of cerebrospinal fluid can be removed at one sitting an attempt should be made to introduce 20 c.e. of serum. If unsucessful, at least 15 c.e. of the serum should he given. I believe that the principle of diphtheria antitoxin, that as much serum as possible be given at one time, can be applied with the same beneficial effects, to the administration of antimeningococcus serum.

How often the administration of serum is to be repeated is also a question that has not yet been definitely decided upon. However, much can be learned from a study of the cerebrospinal fluid and the elinical findings in the particular case. As long as there are bacteria present and as long as the cells are numerous and the patient's temperature is high, it is advisable to administer serum twice a day. It las been my plan to administer 30 c.c. of serum the first time, 30 c.c. the second, third and fourth times, making 120 e.c. in all, irrespective of the cerebrospinal findings. Then if the temperature continues high and the cerebrospinal fluid shows the presence of many cells after waiting one day I administer 30 c.c. additionally even if no bacteria are present. I then wait two days longer and if the case shows no change for the better I administer 30 c.c. more. The following case illustrates the method I usually follow:

March 24, 1917, 7 P.M. F. A., age two and one-half years admitted to hospital with symptoms of meningitis. (See Fig. 56. Light line, pulse; black line, temperature.)

March 24, 8 P.M. Spinal puncture done, 45 c.c. of eloudy fluid removed under increased pressure and 30 c.e. of antimeningococcus serum injected. Cerebrospinal fluid examination showed 53,280 eells per cubic millimeter, 98 per cent of which were polymorphonuclear. Noguchi, Ross-Jones, and Nonne tests werc all positive. Direct smear showed pus cells and gram-negative intracellular diplocoeci (meningoeocei).

March 25, 8:30 A.M. Spinal puncture done, 40 c.e. of yellowish, elondylooking fluid removed under markedly increased pressure; 25 e.e. of serum 
Admission No. 96674

Name J........... $\mathrm{Sard} \mathrm{m} H$

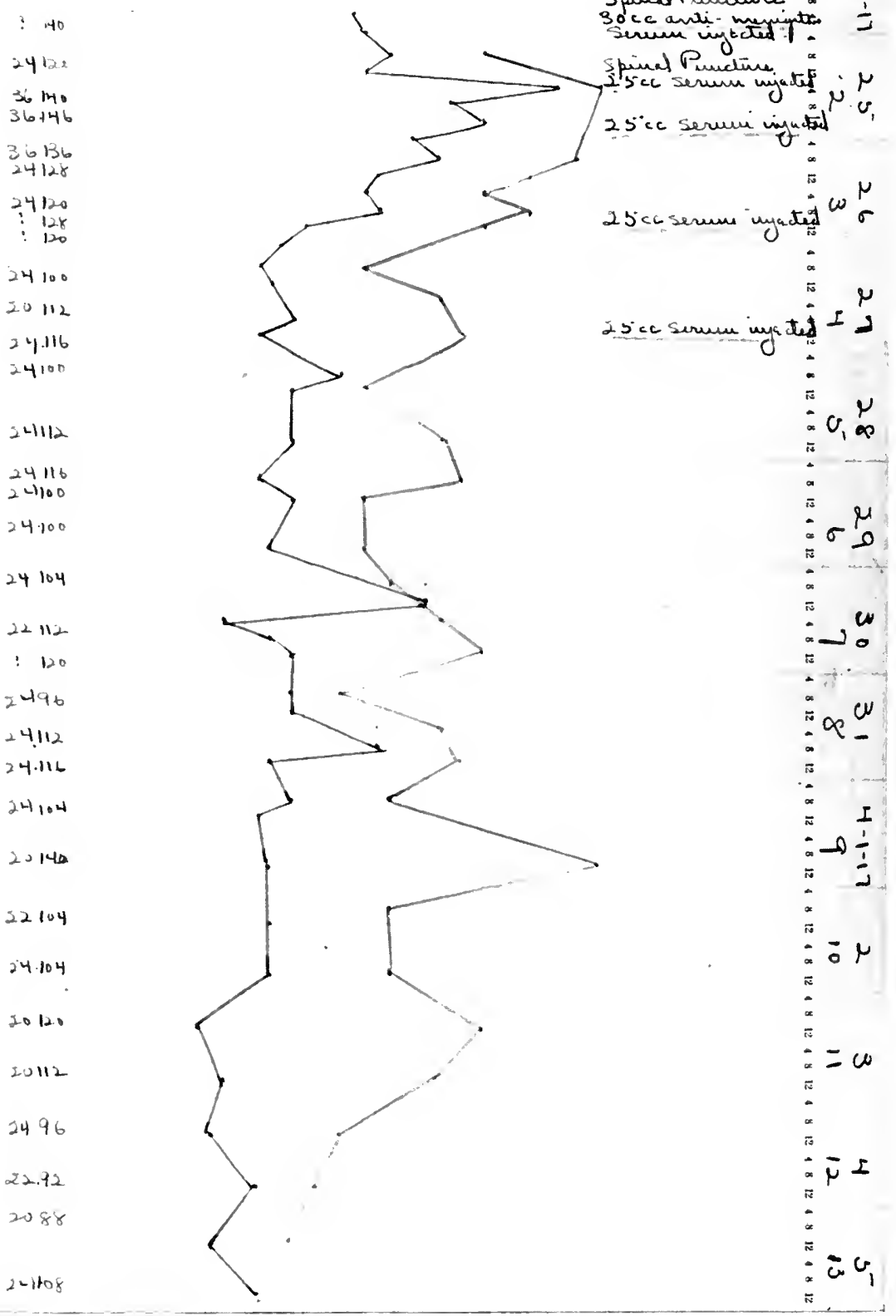


injected. Examination showed 12,000 cells per cubic millimeter, principally polymorphonuclears. Noguchi, Ross-Jones and Nonne were all positive. Meningococei were found in direet smear.

March 25, 11:30 P.M. Thirty-five c.c. eloudy, yellowish fluid removed under slightly increased pressure and 25 e.c. of serum injected. Bouillon cultures made Marelı 24 sliowed meningococei.

March. 26. Twenty-five c.c. of cloudy fluid withdrawn and 25 c.e. of serum injected. Few meningococei found in direct smear, no growth appeared on eultures.

March 27. Thirty e.e. of spinal fluid withdrawn and 25 c.e. of serum injected. Examination slowed polymorphonuclears 85 per cent, lymphocytes 10 per eent, large mononuclears 5 per eent. Globulin tests positive. No growth on eultures.

March 29. Thirty e.e. serum injected. No meningococei found in direct smear and no growth on cultures.

April 2. Cultures made on March 30 and 31 , and April 1 and 2 show no growth.

The following case I believe illustrates the fallacy of administering antimeningococcus serum in too small doses.

D. B., entered the hospital with a history of restlessness, fever, and convulsions. The cerebrospinal fluid removed on entrance to the hospital showed 352 cells per enlic millimeter, all of which were polymorphonuclears. The direet smear showed numerous meningoeocei. Fifteen c.e. of antimeningococcus serum was administered intraspinally and repeated in 12 hours. A third dose of 15 c.c. of serum was given the next day, making a total of 45 c.e. of serum. Since no organisms could be found in the cerebrospinal fluid withdrawn by the third lumbar puncture, the physician recided not to administer any more serum. The patient's temperature was down and she was discharged from the hospital as eured. Two weeks later the patient was readmitted to the hospital with very severe meningeal symptoms. The ecrebrospinal fluid was turbid again and showed meningococei. Sufficient serum was administered this time. 'The child, howerer, did not improve. The meningitis became more severe and the patient died from the disease. If the patient had received sufficient serum, she would most likely liave reeovered from the disease and remained well.

If no sermm can be injected into the spinal canal the serum should be injected intraventricularly, especially in the case of infants. The procedure consists of the withdrawal of a certain amount of cerebrospinal fluid from the ventricles of the brain and of the injection into the ventricles of the brain of the desired amount of serum. If no cerebrospinal fluid can be obtained from either the spinal canal or ventricles, no attempt should be made to inject 
serum into the spinal canal, but should be injected intravenously. In adults the brachial vein may be used. In infants the sorum nuy be injected into the longitudinal silius.

\section{Untoward Effects of Serum}

There are very few complications that follow the injection of antimeningococeus serum and those that do occasionally present themselves are not severe enough to counterindicate the use of the serum treatment. Among the mitoward effects somotimes following the injection may be mentioned:

1. Shock.

2. Aggravation of disease symptoms-the so-called serum meningitis.

3. Serum rash.

Shock occurs in a small percentage of cases. The symptoms consist of respiratory failure and contraction of the pupils. The skin is usually pale but occasionally there is a flush of the skin and even an edema. When shock does occur, it can generally be attributed to the too rapid introduction or to the administration of too large an amount of sermm. As a matter of prophylaxis it is therefore important that the serum be introduced very slowly and, if possible, in amounts not larger than the amount of cerebrospinal fluid removed. For safety's sake the blood pressure should be watched and the serum discontinued if the pressure fall is extreme. It has already been pointed out in the discussion of lumbar puncture that it is dangerous to remove cerrbrospinal fluid from a patient suspected of suffering with meningitis in the sitting position, because of the risk of producing shock and even death. When shock does occur, the adninistration of sermm should be discontinued, and atropine in fairly large doses such as 1/300 in a child, and 1/100 to $1 / 50 \mathrm{in}$ an adult should be administered hypodermatically. This method of treatment has given me very good results. If the atropine does not relieve the symptoms, one c.e. of 
a 1:1000 solution of adrenalin chloride should be given hypodermatically. The occurrence of shock should not prevent one from introducing serum intraspinally into the same patient several hours later. In such cases, I would, however, advise the administration of a dose of atropine previous to the giving of the serum, so as to prevent the repetition of the occurrence.

\section{Aggravation of Symptoms}

Cases have been described in which the patient has become more ill after the administration of serum than before. The exacerbation of symptoms, lowever, is only temporary and should not arouse any anxiety.

\section{Serum Rash}

Antimeningococcus serum, like every other foreign protein introduced into the body, occasionally gives rise to a rash that makes its appearance several days after the administration of the serum. The rash may be macular or papular, but it usually occurs in the form of large blotches similar to those of any other serum raslı. The eruption, as a rule, occurs on the fifth or sixth day after the administration of the first dose of serum. It usually starts from the point of injection of the serum, i.e., from the lumbar region. It may involve only a portion of the body or the entire body. Severe symptoms, such as nausea, romiting and temperature accompany the rash, but they are generally of very short duration. The appearance of the rash often arouses a suspicion of the coexistence of an acute exanthematous disease such as scarlet fever. However, the history of serum injection and the localization of the rash can generally be depended upon to settle the diagnosis.

\section{Intraspinal Treatment of Pneumococcus Meningitis}

Of late the use of antipneumococcus serum has become a matter of common practice in the treatment of pnemmonia. 
One would, therefore, be tempted to use the pneumococcus serum intraspinally in the treatment of pneumococcus meningitis. Broadbent reports four cases of pnemmococeus meningitis that resulted in recovery after administration of antipneumococcus serum. He, however, gave the serum to his patient by moutl. Drought and Kennedy consider intrathecal injection of antipnemmococcic serum mixed with a solution of sodium oleate as the most promising method of treatment. So far very few cases have been reported in which intraspinal injection of antipneumococcus serum has been used and of those that have been reported, none seem to have been followed with any marked degree of success.

Pneumococcus raccine has been used intraspinally by an English physician in the treatment of pneumococcus meningitis. He, however, does not report striking results, either.

Optochin has been administered by some intraspinally for the treatment of pnemmococcus meningitis. I saw one (ase of pueumococcus meningitis in which intraspinal injections in one-half grain doses of optochin (ethyl cuprin hydrochloride) were made and the patient, a child of twelve, recovered. The case in question, however, had also had an intrapinal injection of antimeningococcus sermm previously and this may have been a factor in the recovery, for another case in which optochin was used did not respond farorably. One needs to see more than one case of recovery attributable to the use of optochin before he can endorse its nse. Those who have used horse serum intraspinally do not report any apparent results from its use. In general, then, one can not make any positive statements about the good effects of intraspinal treatment in pneumococcus meningitis. Howerer, until something better can be found $I$ would adrocate repeated lumbar punctures and the injection of polyvalent antipnemus- 
coccus serum, or even ordinary horse serum if no other is obtainable, into the spinal canal.

\section{Intraspinal Treatment in Tuberculous Meningitis}

Of the numerous remedies advocated and tried for the treatment of tuberculous meningitis, none have been attended with sucess. Weak solutions of carbolic acid, eresol, iodine and urotropine lave been siven intraspinally. Thberculin in various dilutions has also been administered. Thus far, neither intraspinal treatment nor any other form of treatment has been of any value in tuberculous meningitis. A few cases have been reported in the literature here and there of tuberculous meningitis resulting in recovery with lealed tubercles; however, from the long list of cases that eulminated in deatl, eases reported both in the literature and in hospital records, one is inclined to doubt the diagnosis of "tubereulous meningitis" in those cases reported as having recovered.

\section{Influenza Meningitis}

Flexner describes a serum for influenza meningitis that is said to be specific. I treated several cases with it without any favorable results, nor did I find any cases of influenza meningitis reported in the literature as having recovered.

\section{Poliomyelitis}

The reports of Rosenow and Nuzum speak very optimistically of the serum treatment of epidemic poliomyelitis. They prepared a serum which they claim is specific against the organism found by them in the brain and cord and also in the cerebrospinal fluid of anterior poliomyelitis. The entire question, however, of the serum treatment of poliomyelitis is still a controversial one, so that it is impossible at present to say just what valuation can be placed on the intraspinal treatment of poliomyelitis. 


\section{The Swift-Ellis Treatment}

It has been the experience of many workers that the best results in the treatment of syphilis of the nervous system are obtained by introducing salvarsan (arsphenamine) or neosalvarsan (neoarsphenamine) into the spinal canal. Salvarsan or neosalvarsan, however, has too irritating an effect upon the meninges. The Swift-Ellis treatment is therefore more efficient. The Swift-Ellis treatment is based on the principle that the blood serum of syphilitics who have been treated with neosalvarsan has a curative effect, and that the best results are obtained when salvarsanized sertum . is brought into direct contact with the central nervous system. The method is as follows:

Salvarsan or neosalvarsan in the proper dose is injected into the patient intravenously, usually into the arm. One hour later 40 c.e. of blood is withdrawn from the patient by means of dry syringe and needle and collected into a sterile centrifuge tube. The blood is allowed to coagulate. The following day the serum is centrifuged for one-half hour till all the cells are sedimented. The centrifuge tube must be plugged with sterile cotton or with sterile rubber caps to prevent contamination of the serum. After centrifugation 12 e.c. of serum is carefully pipetted off with a graduated pipette. The serum is diluted with 18 c.c. of normal salt solution, making a total of 40 per cent of serum. This mixture is heated at $56^{\circ} \mathrm{C}$. for half an hour. Then a lumbar puncture is performed, 15 to 30 e.c. of cerebrospinal fluid is remored from the patient and the 30 c.c. of the serum-sodium chloride mixture is warmed to body temperature and injected into the spinal canal. Here also, as in any other intraspinal treatment the gravity method of injection should be used, to obviate the danger of shock, although some introduce the serum with a Luer syringe without untoward effects. Another precaution to take is to elevate the foot of the bed one hour after the injection. The patient should remain in 
bed for at least one day after the treatment. The treatment is repeated once a week, till the Wassermann, Lange and globulin tests on the cerebrospinal fluid become negative, which usually takes four to five weeks.

The Swift-Ellis treatment las many crities. Sachs, for instance, claims that marked paresis and tabes are not influenced favorably by this form of treatment. Halliburton believes that "the intraspinal injection of salvarsan has been abandoned." Yet in spite of the various objections raised the Swift-Ellis treatment has merit and should be used in selected cases of syphilis of the nervous system. I would only emphasize the great care with which it has to be carried ont in order not to infect the patient and thereby set up a suppurative meningitis.

\section{Intraspinal Treatment of Tetanus}

When tetanus antitoxin is used as a prophylactic measure it is usually injected intramuscularly. However, when the disease is fully developed intraspinal injection is indicated. Tetanus antitoxin when injected into the blood has been found to appear only in traces in the cerebrospinal fluid. When injected directly into the cerebrospinal fluid by the intraspinous method, the serum comes directly into contact with the tetanus toxin and has a preventative if not a curative effect on the tetanus. Although there are other ways of administering tetanus antitoxin, the intraspinal form of administration is one of the most efficient in the treatment of tetanus, particularly if employed in sufficiently large doses.

The method used in administering the serum is the same as that employed for the administration of meningococeus serum, namely, the witlıdrawal of cerebrospinal fluid and the injection of the serum by the gravity method, in a somewhat smaller amount than that of the fluid withdrawn. For instance, if 20 c.c. of fluid has been withdrawn, about 15 c.c. of serum should be injected. The amount injected may 
range from 15 to 30 c.c. depending upon the quantity of fluid withdrawn. The intraspinal administration of serum by means of a syringe is now rarely employed in the treatment of tetanus. Intraspinal injections of magnesium sulphate in the treatment of tetanus have been advocated by many autliors, notably Neltzer.

\section{Intraspinal Treatment of Chorea}

Chorea has been treated by various authors by injecting some substance into the spinal canal of the patient. Lacuna used intraspinal injections of magnesium sulphate. Goodman used autosermm treatment and Porter used lorse serum. The intraspinal magnesium sulphate injection produced no beneficial results in the cases reported by Heiman. Goodman reported a series of cases which he claimed were benefited by his autosermm treatment, which is adninistered in the following manner:

The child is put to bed for four days or longer without medication. At the end of this period 45 or 50 c.c. of blood is withdraw from a vein and rapidly centrifuged. The supernatant blood sermm is then pipetted and kept on ice. A lumbar puncture is made and about 20 c.c. of cerebrospinal fluid is withdrawn. The blood sermu is now heated to body temperature and 15 to 18 c.c. of serum is injected very slowly into the spinal canal. The patient should be made to retain the recumbent position for at least one hour after injection. One injection is usually sufficient. Occasionally, however, it is necessary to give two, three, or even four injections.

\section{Bibliography}

Amoss: Notes on The Standardization and Administration of Antimeningocoecie Sermm, Jour. Am. Med. Assm., 1917, lxix, 1137.

Amoss and Chesney: Sermm Treatment of Polionyelitis, Tomr. Exper. Med., 1917, xxr, 581 .

13roadhent: Treatment of Pnemmocoecie Meningitis, 13rit. Med. Jour., 1916, 586.

Flexner: Experimental Cerehospinal Meningitis and its Serum Treatment, Jour. Am. Med. Assn., 1906, xlrii, 560. 
Flexner and Jobling: Serum Treatment of Epidemic Cerebrospinal Meningitis, Jour, lixper. Med., 1908, x, 141.

Goodman: The Auto-Serum Treatment of Chorea, Arch. Pediat., 1916, xxxiii, 649.

Göppert: Ueber Genickstarre, Ergeb, der Imneren Med., 1909, iv, 165.

Jochmaun: Versuche zur Serodiagnostik und Serotherapie der epidemischen Genickstarre, Deutseh. med. Wehnsehr., 1906, xxxii, 7s5.

Levinson: Pnemmococens Meningitis, Illinois Med. Jour., 1917, xxxii, 270.

MeCoy, Wayson and Corbitt: Potency of Antimeningocoecie Serum, Jour. Am. Med. Assn., 1918, lxxi, 246.

Neal and Abramson: A Comparison of Trieresol and Chloroform as a Preservative in Antimeningitic Serum, Jour. Am. Mod. Assn., 1917, lxviii, 1035.

Nuzum: The Production of an Antipoliomyolitic Sermu, Jour. Am. Med. Assn., 1917, 1xriii, 24.

Nuzum and Willy: Speeifie Serum Therayy of Epidemic Poliomyelitis, Tour. Am. Med. Assn., 1917, 1xix, 1247.

Porter: Intrathecal Injection of Horse Serum in the Treatment of Chorea, Am. Jour. Dis. Child., 1918, xvi, 109.

Rosenow: The Production of an Antipoliomyelitis Serum in Horses, Jour. Am. Med. Assu., 1917, lxiv, 261.

Sachs: Truth About Intraspinal Injections in Treatment of Syphilis of Nervous System, Jour. Am. Med. Assn., 1917, 681.

Swift: Intraspinal Treatment of Syphilis of the Central Nerrous System, Jour. Am. Med. Assn., 1917, lxix, 2092.

Swift and Ellis: The Direet Treatment of Syphilitic Diseases of the Central Nervous System, New York Med. Jour., 1912, xevi, 53.

The Treatment of Syphilitic Affections of the Central Nervous System, with Especial Reference to the Use of Intraspinous Injection, Arch. Int. Med., 1913, xii, 331. 


\section{CIIAPTER IX}

\section{SUMMARY}

I have endeavored to show the varied character of the cerebrospinal fluid in health and in disease. In the consideration of normal fluid the following facts were emphasized: (1) that the fluid is colorless; (2) that it circulates in the cerebrospinal canal; (3) that most of it is absorbed along the spinal cord and some of it in the cavity of the brain; (4) that it is impermeable to most chemicals; (5) that it exerts a protective function. Even under normal conditions cerebrospinal fluid is a most complex fluid consisting of from 98.602 to 99.124 parts of water and 0.876 to 1.398 of solids. The protein content of the fluid which is very small ranges from 0.013 to 0.07 per cent; the mineral content, consisting principally of chlorides and carbonates, ranges from 0.850 to $0.950 \mathrm{gm}$. per 100 c.c. The other elements contained in the fluid, are in the main, the same as those found in other body fluids, although the proportions are different.

I have also pointed out the fact that the H-ion concentration of normal cerebrospinal fluid is practically the same as that of the blood (7.4-7.6) and that $\mathrm{CO}_{2}$ plays an important role in governing the reaction of the fluid, ruming parallel with the H-ion concentration.

In the discussion of pathologic fluid, I pointed out the fact that there are two types of changes: systemic and meningitic, and that the meningitic changes are qualitative as well as quantitative and that the former are of as great if not greater significance than the latter. This was demonstrated by means of the cataphoresis tube, of specific precipitation and varions other tests. 
As to the factors responsible for the qualitative clianges in various diseases no satisfactory explanation has yet been offered, but numerous investigations have convinced me that the changes are intimately associated with the hydrogen-ion concentration. The marked differences noted in the H-ion concentration of different forms of meningitis bear out this contention.

In the discussion of techmic I described both the manner of withdrawing cerebrospinal fluid from the body and the method of examining it after withdrawal. Particular attention was given to those methods that are simple and practical enough to be employed by the physician who has no extensive laboratory facilities.

Under changes in the cerebrospinal fluid in different conditions, I pointed ont the various changes, their diagnostic significance and their relation to the clinical manifestations of the disease.

In the chapter on intraspinal treatment I described both the methods of treatment definitely established and those still in the experimental stage.

In conclusion, I should like to call attention to the following lines of research which I believe are of fundamental value in clearing up some of the contested problems in medicine.

1. The origin and function of the cerebrospinal fluid.

2. The chemical and physicochemical changes taking place in the fluid in various diseases and the principles underlying these changes. The study of this subject will also shed light on the origin of the cerebrospinal fluid.

3 . The chemical and physicochemical relation between the cerebrospinal fluid and other body fluids, especially blood.

4. The crystallization of the cerebrospinal fluid.

The solution of these problems will open limitless opportunities for research not only in the field of cerebrospinal fluid, but in that of every other body fluid. 


\section{APPENDIX \\ Monographs on Cerebrospinal Fluid}

Anglada: Le liquide eeplaalo-rachidien et le diagnostic par. la ponetion lombaire, liailliere et fils, Paris, 1909.

Blumenthal: Über Cerebrospinalfliissigkeit, Ergebnisse d. Physiol., 1902, i, 1. Direksen: Liquide Cephalo-Reeidien y Composition chimique et Coneentrat tion Moleeulaire Thèse de Paris, 1901.

Mestrezat: Le liquide cephalo-rachidien normal et pathologique. Valeur clinique et l'examen chimique. Syndromes humoraux dan diverses affeetions, A. Malloine, Paris, 1912.

Magendie: Recherelses Physiologiques et Clinques sur le Liquide CephaloRachidien on Cerebrospinal, Paris, $18+2$.

Milian: Le liquide cephalo-rachidien, Steinheil, Paris, 1904.

Nonne: Syphilis und Nervensystem, Achtzehnte Vorlesung.

Plaut: Die Wassermannsche Serodiagnostik der Syphilis in ihrer Anwendung auf die Psychiatrie, Fischer, Jena, 1909.

Plaut, Rehm and Schottmüller: Leitfaden zur Untersuchung der Zerebrospinalflüssigkeit, Fischer, Jena, 1913.

Quineke: Über Lumbalpunktion, Die deutsehe Klinik am Eingange des 20. Jahrhunderts, 1906, vi, 1, 351.

English translation: Diseases of the Nervous System, 1910, 223.

Rehm: Die Cerebrospinalflüssigkeit, physikalische, ehemische und eytologisehe Eigenschaften und ihre klinische Verwertung. IIistologisehe und histopathologisele Arbeiten über die Grosshirnrinde (Nissl und Alzheimer), 1909, iii, 1, p. 201.

Sicard: Le liquide eephalo-rachidien, Masson et Cie., Paris, 1902.

Sorrentino: Semeilogia del liquido cefalo-rachidiano, Napoli, 1915.

Thomson: The Cerebrospinal Fluid, William Wood \& Co., 1901. 


\section{INDEX}

A

Absorption of cerebrospinnal fluid, 34,36

Aeidity of eerebrospinal fluid (see Reaetion of cerebrospinal fluid)

Agglutination, 147

of: meningoeocei, 172, 198

of pneumoeocei, 176,202

Alkaline reserve of cerebrospinal fluid:

in meningococeus meningitis, 196

in tubereulous meningitis, 192

normal, 105

pathologie, 132

Alkalinity of cerebrospinal fluid, 44

Amount of cerebrospinal fluid:

inerease in, 116

in meningococeus meningitis, 194

in tubereulous meningitis, 190 normal, 76

Amylolytic power of normal eerebrospinal fluid, 107

Anatomy of eerebrospinal fluid, 30

of chorioid plexus, 31

of subarachnoid space, 30

Antimeningoeoceus serum:

amount administered, 212, 213

cerebrospinal fluid after treatment with, 199

in agglutination of meningococci, $172,173,175$

indieations for, 210

intraspinal treatment with, 209

methods of preservation, 210

methods of production, 210

methods of testing potency of, 210

precipitation of cereliospinal fluid witl, 176

technic of introduction, 211

nutoward effects of, 216

Antipneumoeocens sermm in agglutination of pnemmococei, 176

in treatment of pmeumococcus meningitis, 217, 218

\section{B}

Bacteriology of cerebrospinal fluid, general consideration of, 146

in colon meningitis, 203

in influenza meningitis, 203

in meningococeus meningitis, $196,197,198$

in pneumococeus meningitis. $200,201,202$

in poliomyelitis, 207

in streptocoecus meningitis, 202

in tubereulous meningitis, 193

methods employed, 171

Biemeter, 144

$$
\text { C }
$$

Carbonates in nommeningitic cerebrospinal fluid, 88

Carbon dioxide, amount in normal fluid, 87,91

effect on the hydrogen-ion concentration of fluid, 102, $103,142,144$

Cataphoresis, 134

in meningocoeeus meningitis, 136, 196

in tubereulous meningitis, 135,193 Cells in eerelorospinal fluid (sce Cytology)

Cerebrospinal fluid:

anatomy of, 30

location of, 30

history of, 17

physiology of, 30

absorption of, 36

eireulation of, 3.3, 3.5

formation of, 34

rate of, 34

function of, 40

origill of, 41

in varions diseases, 183

metlots of examination, 1.50

methods of obtaining, 49

cranial puncture, 71

lumbar puncture, 49 
Cerelorospinal fluid-Cont'd

propertics of, normal, 75, (see Normal cerebrospinal fluid) pathologie, 113

Clicmistry of cerebrospinal fluid: normal, 79 pathologie, 123

Chlorides in cerebrospinal fluid: meningitie, 131, 191 method of determination, 161 nonmeningitie, 87,91

Cholesterol in cerebrospiual fluid, 130 Cholin, 130

Chorea, cerebrospinal fluid in, 183

Chorioid plexus:

blood supply of, 31

structure of, 31

Circulation of eerebrospinal fluid, 33, 35

Collection of cerebrospinal fluid, method of, 69 (see Lumbar puncture)

Colloidal gold reaction, 137 (sce Lange gold elloride test)

Colon meningitis, 203

Color of cerebrospinal fluid:

in compression of cord, 189

in hemorrhage of brain, 188

in meningococcus meningitis, 194

in pnenmococeus meningitis, 200

normal, 76

pathologie, 150

Composition of cerebrospinal fluid, (see Chemistry)

Compression of the cord, cerebrospinal fluid in, 189

Conductivity of cerebrospinal fluid: normal, 95 pathologic, 132

Cranial pmeture, indications for, 71 technic of, 71

Grystallization of cerebrospinal fluid: normal, 88

pathologie, 120

Cytology of cerebrospinal thuid: normal, 108

number of cells, 108

type of cells, 110

pathologie, 117

eliorea, 183

compression of rord, 189

encephalitis, 189

epilepsy, 184

influenza meningitis, 203

lues, 186
Cytology of cerebrospinal fluidCont'd

meningism, 190

meningococeus meningitis, 196

p ne u mo coceus meningitis, 200

poliomyelitis, 207

psychoses, 18.j

streptocoeeus meningitis, 202

syphilitie meningitis, 203

tuberculous meningitis, 190

tumor of brain, 189

teelnic employed, 167

\section{D}

Diabetes mellitus, cerebrospinal fluid in, 130,183

Dry puncture, 63

\section{$\mathrm{E}$}

Elimination of phenolphtlıalein from subarachnoid space, 36

Eneephalitis, cerebrospinal fluid in, 189

Epilepsy, cercbrospinal fluid in, 184 Examination of eerebrospinal fluid, methods of, 150

bacteriologie, 171

eulture media, 171

direct smear, 172

chemical, 152

chlorides, 161

globulin, 153

permanganate, 157

protein, 152

sugar, 158

eytologie, 167

Chamber method, 168

Freneh method, 167

guinea pig inoeulation, 177

inımunologie, 172

agglutination, 172

neutralization test, 177

precipitin test, 176

Wassermann, 177

neutralization test, 177

pliysical, color, 150

foam, 151

pelliele, 151

physieochemical, 162

Lange, 164

Mastie, 166

F

Fibrin ferment in cerebrospinal fluid: normal, 107

pathologic, 119

Fosm in pathologic eerebrospinal fluid, 117 
Formation of cerebrospinal fluid, 34

Freezing point of cerebrospinal fluid : normal, 95

pathologic, 132

Function of cerebrospinal fluid, 40

G

Globulin in cerebrospinal fluid:

in meningococcus meningitis, 125,195

in pnenmococeus meningitis, 200

in poliomyelitis, 205

in streptococcus meningitis, 202

in tuberculous meningitis, 125 , 191

relative value of various tests, 156

tests for, 153

Glycolytic ferment in normal cerebrospinal fluid, 107

Guinea pig inoculation, 177, 193

\section{$\mathrm{H}$}

Hemolysin in cerebrospinal fluid:

lack of, in normal, 108

presence of in pathologic, 147

Hemorrhage of brain, cerebrospinal fluid in, 188

History of cerebrospinal fluid, 17

Hydrocephalus, cerebrospinal fluid in, 188

Hydrogen-ion concentration of cerebrospinal fluid:

general consideration of, 96

methods of determination, 163

normal fluid, corked, 102

fresh, 97

old, 97

pathologic, in meningococeus meningitis, 141, 196

in tuberculous meningitis, 141, 192

\section{I}

Inmunology, 147

agglutination, 147

metliods of, 172

- hemolysin, 147

Wassermann, 148

Influenza ineningitis, cerebrospinal fluid in, 203

Inoculation with cerebrospinal fluid, 177,193

Iitraspinal treatment:

of chorea, 222

of influenza meningitis, 219
Intraspinal treatment-Cont'd of meningococeus meningitis, 209 of pneumococcus meningitis, 217 of poliomyelitis, 219

of syphilis of the nervous system, 220

of tetanus, 221

\section{$\mathrm{L}$}

Lange gold chloride test, 137

in ecrebrospinal lnes, 186

in general paresis, 186

in meningococeus meningitis, 196

in polionyclitis, 205

in tabes, $\mathbf{1 8 6}$

in tuberculous meningitis, 192

technic, 164

Location of cerebrospinal fluid, 30

Imes, cerebrospinal fluid in, 185

Lumbar puncture, 49

history of, $24,25,49$

indications for, 49

reasons for failure, 63

structures encountered in, 56

technic of, 54

measurement of pressure, 64

needle used, 57

untoward effects of, 53

\section{M}

Mastic reaction, 137

technic of, 166

Meninges, permeability of, 38

Treningism, cerebrospinal fluid in, 190

Irningitis, cerebrospinal fluid in:

colon, 203

influenza, 203

meningococcus, 194 (see Meningococeus meningitis)

pneumococeus, 200 (see Pueumococcus meningitis)

streptococcus, 202

syphilitic, 203

tuberculous, 190 (sce Tubereulous meningitis)

Mreningococeus meningitis, cerebrospinal fluid in:

amount, 194

alkali reserve, 196

bacteriology, 196, 198

ehemistry, 196

color, 194

eytology, 196

lange gold chloride, 196

pellicle, $19 t$ 
Meningococcus meningitis, cerebrospinal fluid in-Cont'd physicochemical changes, 196 pressure, 194 sediment, 195

intraspinal treatment, 209

Mongolian idiocy, ecrebrospinal fluid in, 184

\section{$\mathrm{N}$}

Neutralization test in poliomyelitis, 177

Ninhydrin reaction, 137

Normal cerebrospinal fluid, 75 amount, 76

Jiochemical properties, 107 elemistry of, 79

table of composition, 91,92 color, 76

eytology of, 108

physical properties, 76

physicochemieal properties of:

alkaline reserve, 105

conductivity, $9 \overline{5}$

freezing point, 95

hydrogen-ion concentration, of, 96

reaction of, 96

refractometric index of, 96

specifie gravity of, 79,94

surface tension of, 95

riscosity of, 95

\section{$\mathrm{O}$}

Organic index (see Permanganate index of cerebrospinal fluid)

Origin of cerebrospinal fluid, 41

\section{$\mathrm{P}$}

Pellicle in cerebrospinal fluid, 118

in meningococeus meningitis, 194

in pneumococens meningitis, 201

in tubereulous meniugitis, 191

Permanganate index of ecrebrospinal fluid, 8.j

normal, 86

pathologic, 123

technie, 157

Permealility of meninges, 38

Pluenolphthalein, elimination of, from subarachmoid space, 36

Pliysical chemistry of cerebrospinal fluid:

normal, 94

pathologie, 1:32
Physiology of cerebrospinal fluid, 30 Preumococeus meningitis, cerebrospinal fluid in:

agglutination, 202

amount, 200

bacteriology, 200

chemical analysis, 200

color, 200

pellicle, 201

physicochemical changes, 200

protein, 200

sediment, 200

intraspinal treatment, 217

Poliomyelitis, cerebrospinal fluid in: amount, 205

bacteriology, 207

cytology, 207

Lange gold chloride test, 205

permanganate index, $20 \overline{5}$

pressure, 205

protein, 205

intraspinal treatment in, 219

Precipitation of cerelnospinal fluid, 125

metallic and alkaloidal, 126

metlods, 153

with antimeningocoecus serum, 176

l'ressure of cerchrospinal fluid:

method of measuring, 64

normal, 77

pathologic, 116

Protein of cerebrospinal fluid:

in meningococeus meningitis, 195

in tuberculous meningitis, 191

method of determination, 152

normal, $81,82,83,84,91$

pathologic, 125

protein eliarges, 133

Pretcolytic power of normal cerebrospinal fluid, 107

Psychoses, cercbrospinal fluid in, 185

\section{$\mathrm{R}$}

Rate of formation of cerebrospinal fluid, 34

Feartion of ecebrospinal fluid:

normal, 96

pathologie, 138

Rofractometric index of normal ecrebrospinal fluid, 96

\section{$\mathrm{S}$}

Sediment in ecrebrospinal fluid, lack of, in normal, 76

meningococens meningitis, 195 (see Pellicle)

tubereulons meningitis, 191 
Serum rash, 217

Specific gravity of cerebrospinal fluid:

normal, 79,94

pathologie, 132

Spina bifida, cerebrospinal fluid in, 188

Streptococeus meningitis, cerebrospinal fluid in, 202

Sugar in cerebrospinal fluid: methods of determination, 158 normal, $83,84,86,91$

pathologie, 129, 130, 183, 191, 196

Surface tension of normal cerebrospinal fluid, 95

Swift-Ellis treatment, 220

Syphilitic meningitis, 203

\section{$\mathrm{T}$}

Tubereulous meningitis, cerebrospinal fluid iı, 190

amount, 190

eataphoresis, 193

chemical changes, 191

hy d rogen-ion concentration, 192

inoculation with, 193

Lange gold cliloride, 192

pelticle, 191

permanganate index, 191

physicochemical changes, 191

pressure, 190

transparency of, 191

tuberele bacilli in, 193

viseosity, 191
Tumors of brain, cerebrospinal fluid in, 189

Turbidity of cerebrospinal fluid, 131

U

Urea in cerebrospinal fluid, 89 nommeningitie, 89

normal, 94

pathologie, 130

Uremia, cerebrospinal fluid in, 183

\section{V}

Viseosity of eerebrospinal fluid:

in neningoeocens meningitis, 196

in tubereulons meningitis, 191

normal, 95

pathologie, 132

W

Wassermann reaction, 148

in cerebrospinal lnes, 186

in ehorea, 184

in general paresis, 186

in mongolian jolioey, 184

in psyehoses, 18:5

in syphilitie meningitis, 203

in tabes, 186

prineiple, 178

teehnic, 179

$\mathrm{X}$

Xanthoeromia, 151, 189 


Date Due

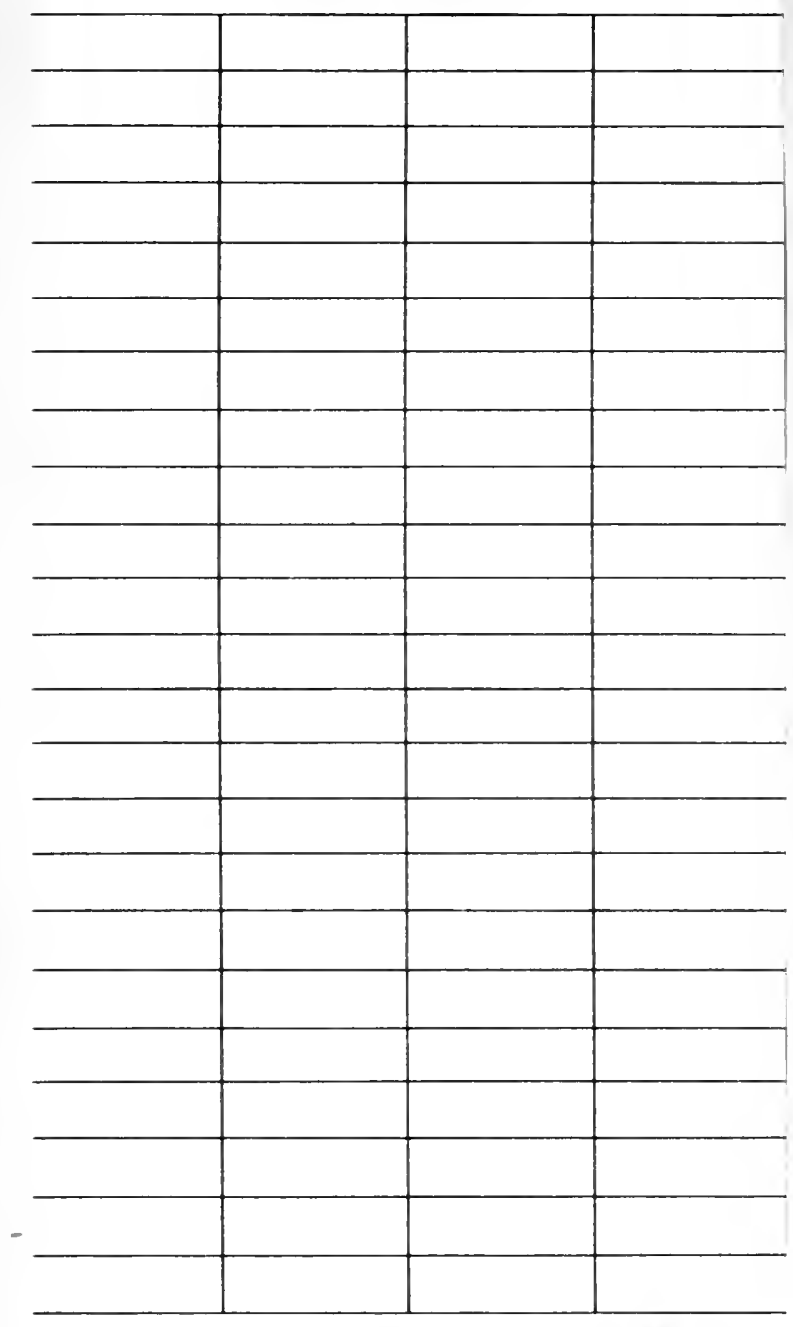

PRINTEDIN U.S.A. CAT. NO. 24161 


\title{
WL203 \\ L657c \\ 1919
}

Levinson, Abraham

Cerebrospinal fluid

\section{WL2O3 \\ L657c \\ 1919}

Levinson, Abraham

Cerebrospinal fluid

\author{
MEDICAL SCIENCES LIBRARY \\ UNIVERSITY OF CALIFORNIA, IRVINE \\ IRVINE, CALIFORNIA 92664
}


5. 58

(3)

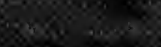

is fo

部

$\%$ 